$\mathrm{DOE} / \mathrm{MC} / 21181--1950-\mathrm{VO} 1.10$

DE88 001008

DOE/MC/21181-1950, Vol. 10

(DE88001008)

Distribution Category UC-132

\title{
Geological Evolution and Analysis of Confirmed or Suspected Gas Hydrate Localities
}

Volume 10. Basin Analysis, Formation and Stability of Gas

Hydrates of the Aleutian Trench and the Bering Sea

J. Krason

M. Ciesnik

Work Performed Under Contract No.: DE-AC21-84MC21181

For

U.S. Department of Energy

Office of Fossil Energy

Morgantown Energy Technology Center

P.O. Box 880

Morgantown, West Virginia 26507-0880

By

Geoexplorers International, Inc.

5701 East Evans Avenue

Denver, Colorado 80222

January 1987 


\section{DISCLAIMER}

This report was prepared as an account of work sponsored by an agency of the United States Government. Neither the United States Government nor any agency Thereof, nor any of their employees, makes any warranty, express or implied, or assumes any legal liability or responsibility for the accuracy, completeness, or usefulness of any information, apparatus, product, or process disclosed, or represents that its use would not infringe privately owned rights. Reference herein to any specific commercial product, process, or service by trade name, trademark, manufacturer, or otherwise does not necessarily constitute or imply its endorsement, recommendation, or favoring by the United States Government or any agency thereof. The views and opinions of authors expressed herein do not necessarily state or reflect those of the United States Government or any agency thereof. 


\section{DISCLAIMER}

Portions of this document may be illegible in electronic image products. Images are produced from the best available original document. 


\section{PREFACE}

This document is Volume $X$ of a series of reports entitled "Geological Evolution and Analysis of Confirmed or Suspected Gas Hydrate Localities." Volume $X$ is a study titled "Basin Analysis, Formation and Stability of Gas Hydrates of the Aleutian Trench and Bering Sea." This report presents a geological description of offshore Alaska, including regional and local structural settings, geomorphology, geological history, stratigraphy, and physical properties. It provides a the necessary regional and geological background for more in-depth research of the area. Detalled discussion of bottom simulating acoustic reflectors, sediment acoustic properties, and distribution of hydrates within the sediments are also included in this report. The formation and stabilization of gas hydrates in sediments are considered in terms of phase relations, nucleation, and crystallization constraints, gas solubility, pore fluid chemistry, inorganic diagenesis, and sediment organic content. Together with a depositional analysis of the area, this report is a better understanding of the thermal evolution of the locality. It should lead to an assessment of the potential for both biogenic and thermogenic hydrocarbon generation.

Project Manager

Gas Hydrates 


\section{DISCLAIMER}

This report was prepared as an account of work sponsored by an agency of the United States Government. Neither the United States Government nor any agency thereof, nor any of their employees makes any warranty, express or implied, or ussumes any legal liability or responsibility for the accuracy, completeness or usefuliness of any information, epparatus, product, or process disclosed, or represents that its use would not infringe privately owned rights, Reference herein to any specific commercial product, process, or service by trade name, trademark, manufactures, or otherwise, does not necessarily constitute or Imply its endorsement, recommendation, or favoring by the United States Government or any agency thereof. The views and opinions of authors expreased berein do not necessarily state or reflect those of the United States Government or any agency thereof.

This report has been reproduced directly from the best available copy.

Available from the National Technical Information Service, U. S. Department of Commerce, Springfield, VA 22161.

Price: Printed copy A06 Microfiche A01

Codes are used for pricing all publications. The code is determined by the number of pages in the publication. Information pertaining to the pricing codes can be found in the current issues of the following publications, which are generally available in most libsaries. Energy Research Abstracts (ERA), Covemnent Reports Announcements and Index (GRA and $)$, Sientific and Technical Abstract Roports (STAR); and publication NTIS-PR - 360 available from NTIS at the above address. 


\section{CONTENTS}

Executive summary. $\ldots \ldots \ldots \ldots \ldots \ldots \ldots \ldots$ Introduction ......................

Part I

Basin analysis of the Aleutian Trench and Bering Sea regions .... 6

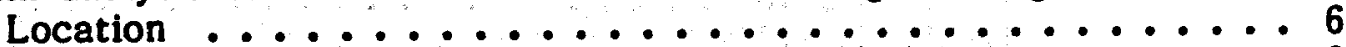

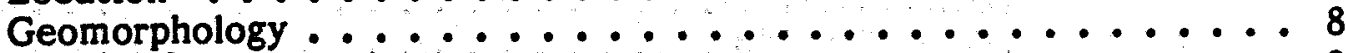

Central and eastern Aleutian Trench system ......... 8

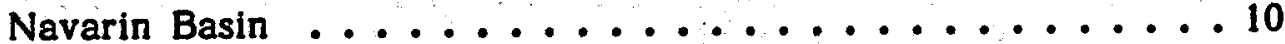

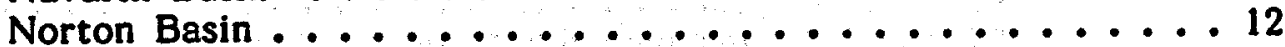

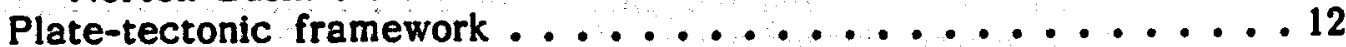

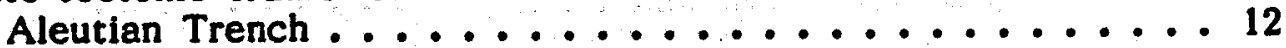

Tectonic evolution of Bering Sea region ............. 13

Structural setting of the Navarin Basin and the Norton Basin ... 17

Basement in the Northern Bering Sea ............ 17

Structural features of the Navarin Basin .......... 19

Tectonics of the Norton Basin . . . . . . . . . . . 24

Saint Lawrence Subbasin ................ 25

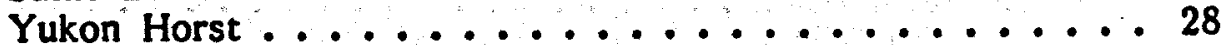

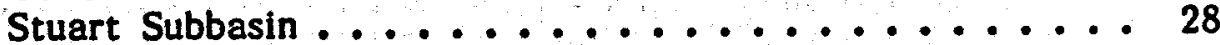

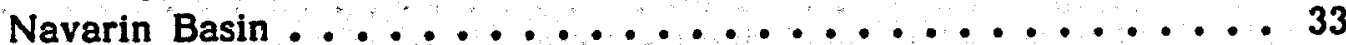

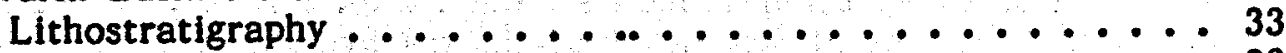

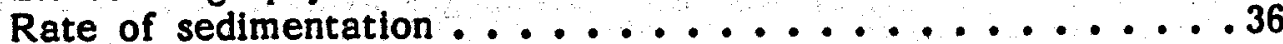

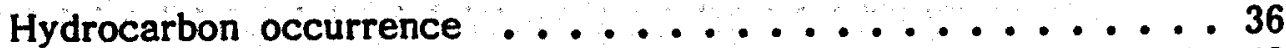

Thermogenic hydrocarbons .................40

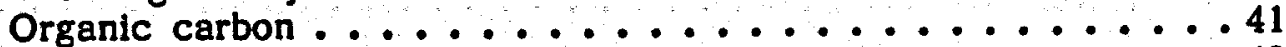

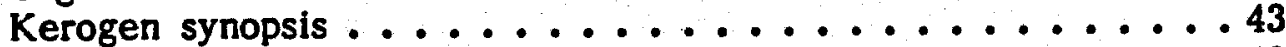

Thermal maturation and hydrocarbon potential ........43

Seismic expression of free gas in sediment ..........44

Reflector pulldown ................. 44

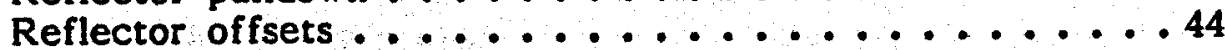

Reflector termination ................. 49

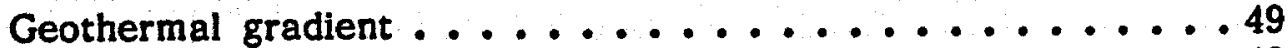

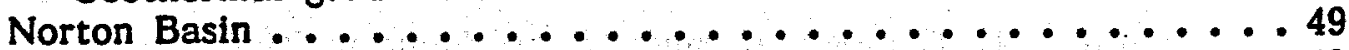

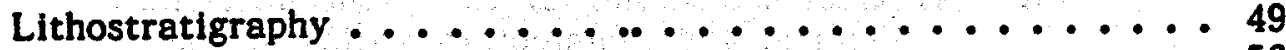

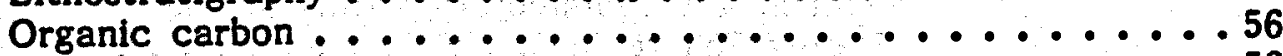

Kerogen characteristics .................. 56

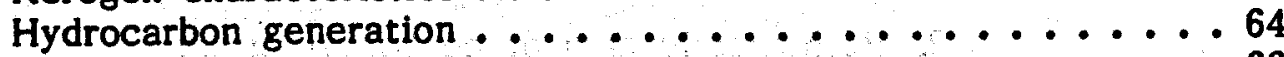

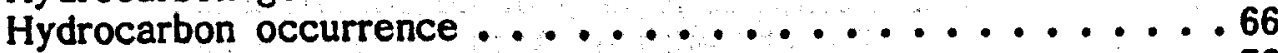

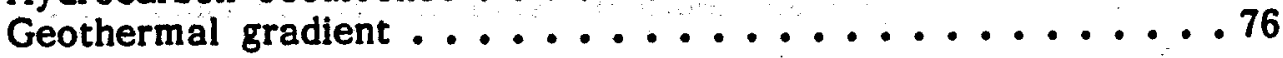


Structural setting of the Aleutian Trench system . . . . . . 79

Central Aleutian Trench . . . . . . . . . . . . 79

Eastern Aleutian Trench . . . . . . . . . . . . . . 80

Atka Basin ...................... 83

Lithostratigraphy ...................83

Rate of sedimentation ................88

Organic matter ....................88

Hydrocarbon gas in sediment .............. 88

Geothermal gradient .................. 94

Eastern Aleutian Trench-Arc system . ........... 95

Sedimentation and lithostratigraphy ........... 95

DSDP Site $178 \ldots \ldots \ldots \ldots \ldots \ldots \ldots$

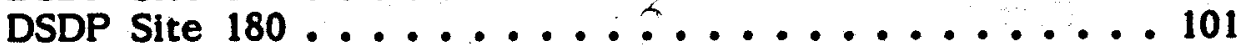

DSDP Site $181 \ldots \ldots \ldots \ldots \ldots$................ 104

DSDP Site $182 \ldots \ldots \ldots \ldots \ldots \ldots \ldots$................... 104

DSDP Site $183 \ldots \ldots \ldots \ldots \ldots$.................. 104

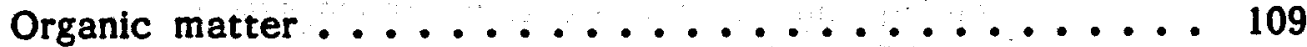

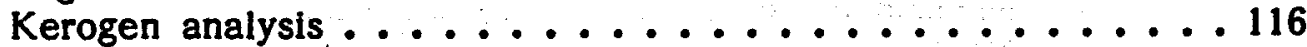

Thermogenic and biogenic gases ............ 118

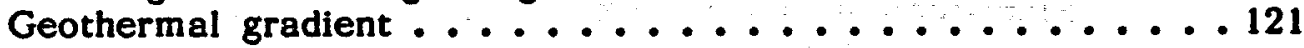

Part II

Formation and stability of gas hydrates . . . . . . . . . 122

Bottom simulating reflectors related to gas hydrates . . . . . 122

Diagenetic bottom simulating reflectors . . . . . . ..... 124

Navarin Basin . . . . . . . . . . . . . . . . . 124

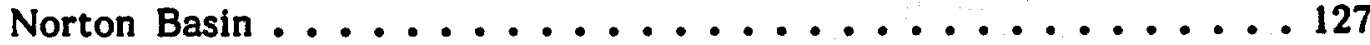

Atka Basin ........................ 134

Eastern Aleutian Trench system ............... 135

Assessment of gas resources in gas hydrates ........... 137

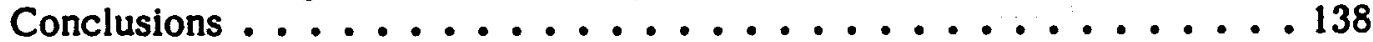

References ......................... 143

\section{ILLUSTRATIONS}

Figure 1. Geologic setting of the Aleutian Islands, Trench and sedimentary basins of the

Bering Sea region ................ 7

2. Bathymetric map of central Aleutian

Trench south of Atka and Amlia islands ......... 9 
Figure 3. Bathymetric map of Navarin

Basin and vicinity .................11

4. Reconstruction of the tectonic plate

locations, based on paleomagnetic data . . . . . . . . 14

5. Generalized maps of late Mesozoic and

early Tertiary plate motions along

Beringian margin--Patton's model . . . . . . . . . 16

6. Structure contour map of acoustic basement

in the Navarin Basin ................ 20

7. Location map of two profiles shown

on Figures 8 and $9 \ldots \ldots \ldots \ldots \ldots \ldots \ldots$

8. Interpretative drawing of seismic reflection

profile A-B across the Navarin Basin . . . . . . . . . 22

9. Interpretative drawing of seismic reflection

profile C-D across the Navarin Basin . . . . . . . . .23

10. Norton Basin--structure contours

of the horizon A............... 26

11. Contour map of gravity anomalies over.

the Norton Basin and Yukon delta . . . . . . . . . . 27

12. Seismic lines from central Norton Basin area . . . . . . . 29

13. Regional seismic section through

western Norton Basin . . . . . . . . . . . . . .30

14. Seismic section from central Norton Basin ........ 31

15. Lithostratigraphic zones and paleobathymetry

In COST well No. 1, Navarin Basin ............ 32

16. Maximum concentrations of methane (in $L / L$ )

in gravity cores from the Navarin continental margin ... 38

17. Characteristics of organic matter of

sediments in COST well No. 1, Navarin Basin . . . . . . .42

18. Vitrinite reflectance and $T_{2}$-max from

pyrolysis, COST well No. 1 , Navarin Basin ........ 45

19. Locations of the seismic lines shown in

Figures 20, 21 and $22 \ldots \ldots \ldots . \ldots \ldots$ 
Figure 20. Airgun profile $1(75-20 \mathrm{~Hz})$ from the Navarin Basin showing pulldowns associated with gas-charged sediment ............. 47

21. Uniboom profile $(400-2,500 \mathrm{~Hz})$ from the

Navarin Basin showing reflector of fsets attributed to gas-charged sediment . . . . . . . . . 48

22. Minisparker profile $2(150-1,100 \mathrm{~Hz})$ from the norther part of Navarin Basin showing reflector terminations and pulldowns attributed to gas-charged sediment ........... 50

23. Distribution of seismic anomalies in Navarin Basin attributed to gas-charged sediment ........51

24. Thermal gradient in the Navarin Basin COST No. 1 well .. 52

25. Stratigraphic column and summary chart of geological data, Norton Sound COST No. 1 well .......54

26. Results of geochemical analyses of rock samples from Norton Basin COST No. 1 well . . . . . . . . . . .57

27. Classification of organic matter in the profile of Norton Basin COST No. 1 well ......... . 58

28. Van Krevelen diagram and results of the pyrolysis analyses--Norton Basin COST No. 1 well . . . . 60

29. Results of the Kerogen analyses--Norton Basin COST well No. 1...............61

30. Collection sites of geochemical samples shown in Table 3

31. Projection of hydrocarbon generation in the Norton Basin

32. Distribution of $\mathrm{CH}_{4}$ in surface water in $\mathrm{ml} / \mathrm{l}$ (STP) in the Norton Sound area-September $1976 \ldots \ldots \ldots \ldots$. . . . . . . . . . . .

33. Distribution of $\mathrm{CH}_{4}$ in water, $5 \mathrm{~m}$ above the sea floor in the Norton Sound area-September 1976 . . . . . . . . . . . . . . . .

34. Distribution in $\mathrm{ml} / \mathrm{l}$ (STP) of ethane in water, $5 \mathrm{~m}$ above the sea floor in the Norton Sound area--September $1976 \ldots \ldots \ldots \ldots \ldots$ 
35. Distribution of $\mathrm{C}_{3} \mathrm{H}_{8}$ in water, $5 \mathrm{~m}$ above the sea floor in $\mathrm{ml} / \mathrm{l}$ (STP) in the Norton

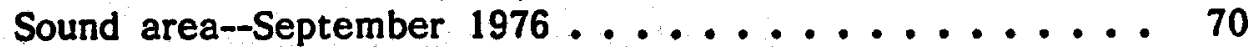

36. Diagram illustrating ratio $C_{1} / C_{2}+C_{3}$ hydrocarbons in water, $5 \mathrm{~m}$ above the sea floor in the Norton Sound area--September $1976 \ldots \ldots 71$

37. USGS seismic line 802 , Norton Basin . . . . . . . . . 72

38. Location of two sites with documented gas seep (Site 3) and sediment saturated with hydrocarbon gas ....................

39. Locations of seismic survey grids $A$ and $B$ with positions of multichannel seismic lines ........ 81

40. Depth section of seismic line 111 from grid $A$ in Figure $39 \ldots \ldots 82$

41. Time sections of seismic line 13 and seismic line $D \ldots \ldots \ldots \ldots$

42. Lithostratigraphy and physical properties of sediments at DSDP $\operatorname{Leg} 19$, Site $186 \ldots \ldots$

43. Lithostratigraphy and physical properties of sediments at DSDP Leg 19, Site $187 \ldots \ldots$

44. Diagram of uncorrected rate of sedimentation at DSDP Site $186 \ldots \ldots \ldots \ldots$

45. Variation in $C_{1} / C_{2}$ ratios with depth and with different thermal regimes across the Aleutian Arc system ..............

46. Locations of DSDP sites (Leg 18) in the eastern Aleutian Trench-Arc system ............ 9

47. Rate of sedimentation at DSDP sites of Leg 18

48. Lithostratigraphy and physical properties of sediments at DSDP Leg 18, Site $178 \ldots 100$

49. Lithostratigraphy and physical properties of sediments at DSDP Leg 18, Site $180 \ldots \ldots$.....

50. Lithostratigraphy and physical properties of sediments at DSDP Leg 18, Site 181 
Figure 51. Lithostratigraphy and physical properties

of sediments at DSDP Leg 18, Site $182 \ldots \ldots \ldots \ldots$

52. Lithostratigraphy and physical properties

of sediments at DSDP Site 183, Leg 18 ........ 107

53. Results of geochemical analysis of sediment

samples at DSDP Site $178, \operatorname{Leg} 18 \ldots \ldots \ldots \ldots \ldots \ldots$

54. Results of geochemical analysis of sediment

samples at DSDP Site 180 , Leg $18 \ldots \ldots \ldots \ldots \ldots$

55. Results of geochemical analysis of sediment

samples at DSDP Site $181, \operatorname{Leg} 18 \ldots \ldots \ldots \ldots \ldots 114$

56. Results of geochemical analysis of sediment

samples at DSDP Site 183 , Leg $18 \ldots \ldots \ldots \ldots \ldots$

57. Van Krevelen diagram and results of geochemical analyses of organic matter

on nine samples from the Aleutian Trench area . . . . . 117

58. X-ray diffractograms showing progressive transformation of biogenic opal-A into

oal-CT in sediments from DSDP Site $188 \ldots \ldots \ldots \ldots$

59. Seismic reflection profile crossing the area in the vicinity of the Navarin Basin

No. 1 well . . . . . . . . . . . . . . . . . 126

60. Anomalous changes of interval transit time in the diagenetic zone, Navarin Basin

CosT No. 1 well .................

61. Changes of porosity and bulk density of diatomaceous sediments in the Navarin

Basin COST No. 1 well . . . . . . . . . . . . .

62. Location of seismic lines shown in

Figures 62,63 , and $64 \ldots \ldots \ldots \ldots$

63. Seismic line from the Navarin Basin area ........ 131

64. Seismic line from the Navarin Basin area . . . . . . 132

65. Seismic line from the Navarin Basin area ........ 133

66. Seismic line across the Aleutian Trench

and western Gulf of Alaska .............. 136 


\section{TABLES}

Table 1. Core samples from Navarinsky Canyon with $C_{1}$ concentrations greater than $1,000 \quad 1 / 1 \ldots \ldots . \ldots . . .37$

2. Navarin Basin cores with possible thermogenic hydrocarbons . . . . . . . . . . . 40

3. Organic geochemical data from general area of Norton Basin . . . . . . . . . . . . 62

4. Dissolved hydrocarbon concentrations within $5 \mathrm{~m}$ of the sea floor at the two stations in Norton Basin ..................... . . 73

5. Chemical and isotopic composition of gas at Sites 3 (gas seep) and 4 (gas from the sediment in Norton Basin area) . . . . . . . . . . 74

6. Gas composition in sediments, Norton Basin . . . . . . 77

7. Concentrations of hydrocarbons in core sediment samples from the Norton Basin ............. 78

8. Organic carbon content in profile of the DSDP, Site $186 \ldots \ldots \ldots \ldots$

9. Chemical and isotopic composition of gas samples in sediment at DSDP Site $186 \ldots \ldots \ldots \ldots 1$

10. Organic carbon and hydrocarbon gas content at the DSDP Site $186 \ldots \ldots \ldots \ldots \ldots \ldots$. . . . . 92

11. Results of geochemical analyses of kerogen from eastern Aleutian Trench ..............110

12. Results of geochemical analyses of the organic matter in rock samples from eastern Aleutian Trench area. .111

13. Chemical and isotopic composition of the gas from sediment at DSDP Site $180 \ldots \ldots \ldots \ldots$

14. Organic carbon and hydrocarbon gas from canned core samples in DSDP Site $180 \ldots \ldots \ldots . . .119$

15. Median hydrocarbon gas concentrations and gas ratios .................... 120 


\section{EXECUTIVE SUMMARY}

Four major areas with inferred gas hydrates, listed by Kvenvolden and Barnard (1983) among the 24 locations worldwide, are the subject of this study. Two of these areas, the Navarin and the Norton basins, are located within the Bering Sea shelf, whereas the remaining areas of the Atka Basin in the central Aleutian Trench system and the eastern Aleutian Trench represent a huge region of the Aleutian Trench-Arc system (Figure 1). All four areas are geologically diverse and complex. Particularly the structural features of the accretionary wedge north of the Aleutian Trench still remain the subjects of scientific debates.

Prior to this study, suggested presence of the gas hydrates in the four areas (Kvenvolden and Barnard, 1983) was based on seismic evidence, i.e. presence of bottom simulating reflectors (BSRs). Thorough study of publically available literature and seismic data enabled us to identify the gas hydraterelated BSRs only in the upper and middle continental slopes in the west flanks of the Navarin Basin and in the eastern Aleutian Trench-Arc sedimentary complex. Although the disclosure of the BSRs is often difficult, particularly under the structural conditions of the Navarin and Norton basins, it can be concluded that the identified BSRs are mostly represented by relatively weak and discontinuous reflectors. Under thermal and pressure conditions favorable for gas hydrate formation, the relative scarcity of the BSRs can be attributed to insufficient gas supply to the potential gas hydrate zone. Hydrocarbon gas in sediment may have biogenic, thermogenic or mixed origin. In the four studied areas, basin analysis revealed limited biogenic hydrocarbon generation. The migration of the thermogenically derived gases is probably diminished considerably due to the widespread diagenetic processes in diatomaceous strata. The latter processes resulted in the formation of the diagenetic horizons including opal CT. The identified gas hydrate-related BSRs seem to be located in the areas of increased biogenic methanogenesis and faults acting as the pathways for thermogenic hydrocarbons.

The potential of gas hydrates in the Norton Basin, suggested by Kvenvolden and Barnard (1983) with reference to personal communication with Mousseau, appears to be questionable. The anomalous seismic reflectors featuring the gas hydrates would be extremely difficult to recognize in the area due to the structural conditions. Shallow water, relatively high water temperature (also varying with annual seasons), high geothermal gradient and overall low saturation of pore water in gas, do not create a favorable gas hydrate hosting environment. Patchy and irregular gas hydrate zones could be potentially related to the remnants of permafrost preserved from the Pleistocene epoch and locally increased amounts of blogenically and thermogenically derived hydrocarbons. Major factors related to gas hydrate formation in the individual study areas can be summarized as follows: 


\section{Navarin Basin}

1. The Navarin Basin is composed of three subbasins trending in a northwestern direction. Thickness of the sedimentary sequence in these depocenters reaches 3,660 to $4,570 \mathrm{~m}$.

2. As the sediments of the upper strata lie horizontally and are devoid of major tectonic disruptions, the potential structural traps for migrating hydrocarbons occur in deeper sedimentary sections of the central basin and in pinching out strata in the basin's flanks.

3. Faults which may play a role as conduits for migrating thermogenic hydrocarbons occur mainly on the continental slope and in the outermost shelf areas.

4. Porous marine lithologies represented by sediments of middle bathyal to inner neritic zones create a favorable host environment for gas hydrates.

5. The hydrocarbon gases in sediments were found to be in undersaturated state and mostly of biogenic origin. The thermogenic gases were also identified.

6. The high rate of sedimentation in the Navarin Basin (100 to $\left.350 \mathrm{~m} / \mathrm{m} . \mathrm{y}_{.}\right)$ is a favorable factor in the process of biogenic methanogenesis.

7. The average content of the organic carbon in the Navarin Basin ranges from 0.5 to 2 percent.

8. Presence of the silica diagenetic boundaries differentiates significantly the geothermal gradients in vertical profile of the Navarin Basin $\left(2.95^{\circ} \mathrm{C}\right.$ to $\left.4.46^{\circ} \mathrm{C} / 100 \mathrm{~m}\right)$.

9. The most favorable conditions for gas hydrate formation occur in the area of upper and middle continental slope.

10. Assuming 10 percent areal extent of the gas hydrates and a $350 \mathrm{~m}$ thick hydrate zone, the gas reserves in this zone have been estimated at 185 TCF.

\section{Norton Basin}

1. The Norton Basin represents a downwarp area in northwestern Bering Sea shelf and it is composed of two subbasins.

2. The sediments filling the basin are of Tertiary age and their maximum thickness reaches $3,800 \mathrm{~m}$. 
3. Major lithologies in the basin are represented by mudstones and siltstones interbedded with sandstones, shales and coal.

4. The average values of total organic carbon (TOC) in the basin's sediments vary from 0.8 to 2.0 percent.

5. The elemental analyses of kerogen showed that only limited parts of the basin have favorable conditions for thermogenic hydrocarbon generation.

6. Analyses of hydrocarbon gases from sediment indicate their thermogenic provenance.

7. Biogenic methanogenesis in the Norton Basin is only locally increased.

8. The geothermal gradient in the basin area ranges within $4-4.5^{\circ} \mathrm{C} / 100 \mathrm{~m}$.

9. The sea depth over the entire Norton Basin ranges from 0 to $25 \mathrm{~m}$, thus creating unfavorable conditions for gas hydrate formation and stability. The oxidized environment at the sea bottom and elevated temperature seem to be key factors.

\section{Atka Basin}

1. The $926 \mathrm{~m}$ thick sediments were found in the vicinity of DSDP sites 186 and 187, where gas hydrate presence has been suggested (Kvenvolden and Barnard, 1983). The lithologic sequence consists of silty clays, volcanic ashes and silty sands.

2. Values for organic carbon in the sediments of Atka Basin are below 0.5 percent.

3. High sedimentation rates $(\sim 180 \mathrm{~m} / \mathrm{m} . \mathrm{y}$.$) prevent the organic matter from$ oxidation to a significant degree.

4. Gases of mostly biogenic origin were found in sediments of the Atka Basin.

5. Geothermal gradients in the Atka Basin are low and display values ranging from 1.8 to $2.5^{\circ} \mathrm{C} / 100 \mathrm{~m}$.

6. The seismic anomalous reflectors (BSRs) related to the gas hydrates do not appear to be conspicuous in the Atka Basin. Gas availability is probably a key factor. 


\section{Eastern Aleutian Trench-Arc}

1. Clayey silt and sands constitute major lithologies within the continental slope of this area.

2. Total organic carbon (TOC) in sediments ranges from traces to 0.8 percent.

3. Low values of total hydrocarbon yield $(0.03-0.10$ percent) were found in the sediment samples.

4. The volatile hydrocarbons in sediments did not exceed $200 \mathrm{ppm}$.

5. The potential for thermogenically derived hydrocarbons related to the subduction of the oceanic lithosphere was found to be moderate to low.

6. Geothermal gradient in the area of the eastern Aleutian Trench-Arc system is $2.8^{\circ} \mathrm{C} / 100 \mathrm{~m}$.

7. Study of $2,500 \mathrm{~km}$ of high resolution seismic lines revealed only two weak and discontinuous BSRs in the middle continental slope east of Kodiak Island.

8. With all limitations of the gas hydrate presence in the eastern Aleutian Trench-Arc sediments, gas reserves in the potential gas hydrate zone have been assessed at 369 TCF. 


\section{INTRODUCTION}

Basin analysis is well recognized as a multidisciplinary scientific methodology. It is applicable particularly for evaluation of the geological conditions and assessment of hydrocarbon potential in a relatively large but insufficiently known sedimentary basin, and structurally or geographically defined regions. The basin analysis methodology is also very useful and, therefore, it has been applied in Geoexplorers International, Inc. research aiming for determination of the formation and stability of gas hydrates in 24 offshore locations in various parts of the world with confirmed or inferred presence of gas hydrates.

This extensive research project of which this report is a part has been performed for the U.S. Department of Energy - Morgantown Energy Technology Center (DOE-METC). The published literature and publicly available data, including especially seismic survey results, mostly not interpreted with reference to gas hydrate formation and stability, have been used as a data base.

The basin analysis and factors directly pertaining to gas hydrates in the Bering Sea and the Aleutian Trench regions, focusing particularly on four areas with prevlously reported inferred gas hydrates (Kvenvolden and Barnard, 1983), are the main content of this report.

The Navarin and Norton basins (totaling approximately $125,000 \mathrm{~km}^{2}$ ) are located within the Bering Sea region, of which the continental shelf encompasses $1,900,000 \mathrm{~km}^{2}$ (i.e. an area twice larger than the states of California, Oregon and Washington combined). Both basins have been selected for the basin analysis and gas hydrate formation and stability study on the basis of seismic evidence reported by Kvenvolden and Barnard (1983). This study revealed geological conditions generally of low favorability for gas hydrates in both basins (in this report also referred to as the study areas), but the continental slope west of the Navarin Basin appears to be the most favorable for gas hydrate potential.

Two study areas also included in this report are located in central and eastern parts of the Aleutian Trench system. Respectively these latter areas are referred to as the Atka Basin and eastern Aleutian Trench. Although the thermodynamic conditions in both study areas appear to be mostly in the gas hydrate stability field, there is apparent lack of ubiquitous seismic bottom simulating reflectors (BSRs), considered as indirect evidence of gas hydrate presence.

The anomalous discontinuous BSRs have been confirmed in the sediments of the eastern Aleutian Trench system. It seems that the gas availability has been a decisive factor. The analyses of hydrocarbons in the sediments indicate the thermogenic origin whereas the biogenic methanogenesis appears to be of secondary nature. Therefore, the distribution of the gas hydrates in this study area is probably related to the fault system which acted as the hydrocarbon migration path for thermogenically derived hydrocarbons. 


\section{PART I}

\section{BASIN ANALYSIS OF THE ALEUTIAN TRENCH AND BERING SEA REGIONS}

\section{Location}

This study covers large regions of the northern part of the Pacific Ocean known as the Aleutian Trench and Bering Sea.

Originally, the presence of gas hydrates in four areas of these regions was suggested by Kvenvolden and Barnard (1983). These areas have been defined as follows:

1. North Pacific Ocean, south of the Aleutian Islands, near DSDP Site 186.

2. North Pacific Ocean, south of the eastern Aleutian Islands.

3. Continental slope, Bering Sea, near Navarin Basin.

4. Norton Sound, Bering Sea off Alaska.

All of these areas are confined to two geographically and geologically diverse regions. The first two areas are located south of the central and eastern parts of the volcanogenic arc of the Aleutian Islands which links the Alaska Peninsula on the east end with the Kamchatka Peninsula to the west (Figure 1). The Aleutian Islands, or geologically, the Aleutian Islands arc system, constitute the northern boundary for the Pacific Ocean region.

The Bering Sea region spreads to the north of the Aleutian Islands and is bounded by western Alaska, eastern Siberia, and the Bering Strait, which connects waters of the Bering Sea and Chukchi Sea to the north.

Norton Basin and Navarin Basin are two of the most pronounced depocenters within the shelf and continental slope of the northern Bering Sea (Figure 1).

Norton Basin, which coincides with Norton Sound, is defined by an area elongated in an east-west direction. Geographically, the Norton Basin is located between latitudes of $63^{\circ} 20^{\prime} \mathrm{N}$ and $64^{\circ} 30^{\prime} \mathrm{N}$. In the eastern part, the Norton Basin is bordered by the Seward Peninsula to the north, by the Yukon-Koyakuk province on the east and by the Yukun River delta to the south. The western boundary of the Norton Basin is almost parallel to the $167^{\circ} \mathrm{W}$ meridian (Figure 1 ). 
Navarin Basin is located south of the Navarin Cape along the outer shelf of the Bering Sea between $62^{\circ} \mathrm{N}$ and $57^{\circ} 40^{\prime} \mathrm{N}$ latitudes. The outline of the Navarin Basin shown in Figure 13 delineates the part of the basin where the sediment fill is thicker than $2,000 \mathrm{~m}$.

\section{Geomorphology}

The geomorphology of the sea floor in all four study areas is highly differentiated. The differentiation is governed mainly by their tectonic position. The two areas of the north Pacific Ocean region are located within a large tectonic unit, which is referred to by Grow (1973) as the Aleutian frontal arc. The frontal arc is associated with the Aleutian Trench system. The remaining two areas are located within the continental margin, mainly in its shelf (Figure 1).

\section{Central and Eastern Aleutian Trench}

The geomorphology and structural features of the central Aleutian Trench have been described by Grow (1973) and most recently by Scholl et al. (1983). The latter authors used primarily single-channel and nonmigrated multichannel seismic reflection profiles. The detalled bathymetric map of the area south of the Atka and Amlia islands presented by McCarthy and Scholl (1985; Figure 2) shows all the major geomorphological features of the central part of the Aleutian Trench. The landward slope of the central Aleutian Trench displays a fairly regular geomorphological pattern. Three distinct topographic parts can be delineated along the vertical section of this slope:

a. The upper slope between the 200 and $4,200 \mathrm{~m}$ isobaths. The width of this section varies from 25 to $30 \mathrm{~km}$ while the slope descends at an average angle of $7.5^{\circ}$.

b. The middle slope represents a relatively flat area dipping at an average angle of $0.4^{\circ}$. This approximately $50 \mathrm{~km}$ wide terrace-like section is probably the most characteristic geomorphological feature of the central Aleutian Trench landward slope. In Seely's (1979) classification, those forearcs (1.e. areas between active volcanic areas and outer edges of oceanic trenches associated with that arc) which have such bathymetric breaks are defined as terraced forearcs. In the case of the landward slope of the central Aleutian Trench system, the terrace should also be classified as a ponded terrace since it was formed by sediment ponding behind an elevated terrace edge. Atka Basin, which is located within the central part of the Aleutian Trench, apparently constitutes the biggest depression in the geomorphologic surface of the terrace.

c. The lower slope encompasses the area between the 4,600 $\mathrm{m}$ and 7,200 $m$ isobaths. The area south of the Atka Basin is approximately 35 $\mathrm{km}$ wide and ascends toward the trench floor at an average angle of $4.5^{\circ}$. 


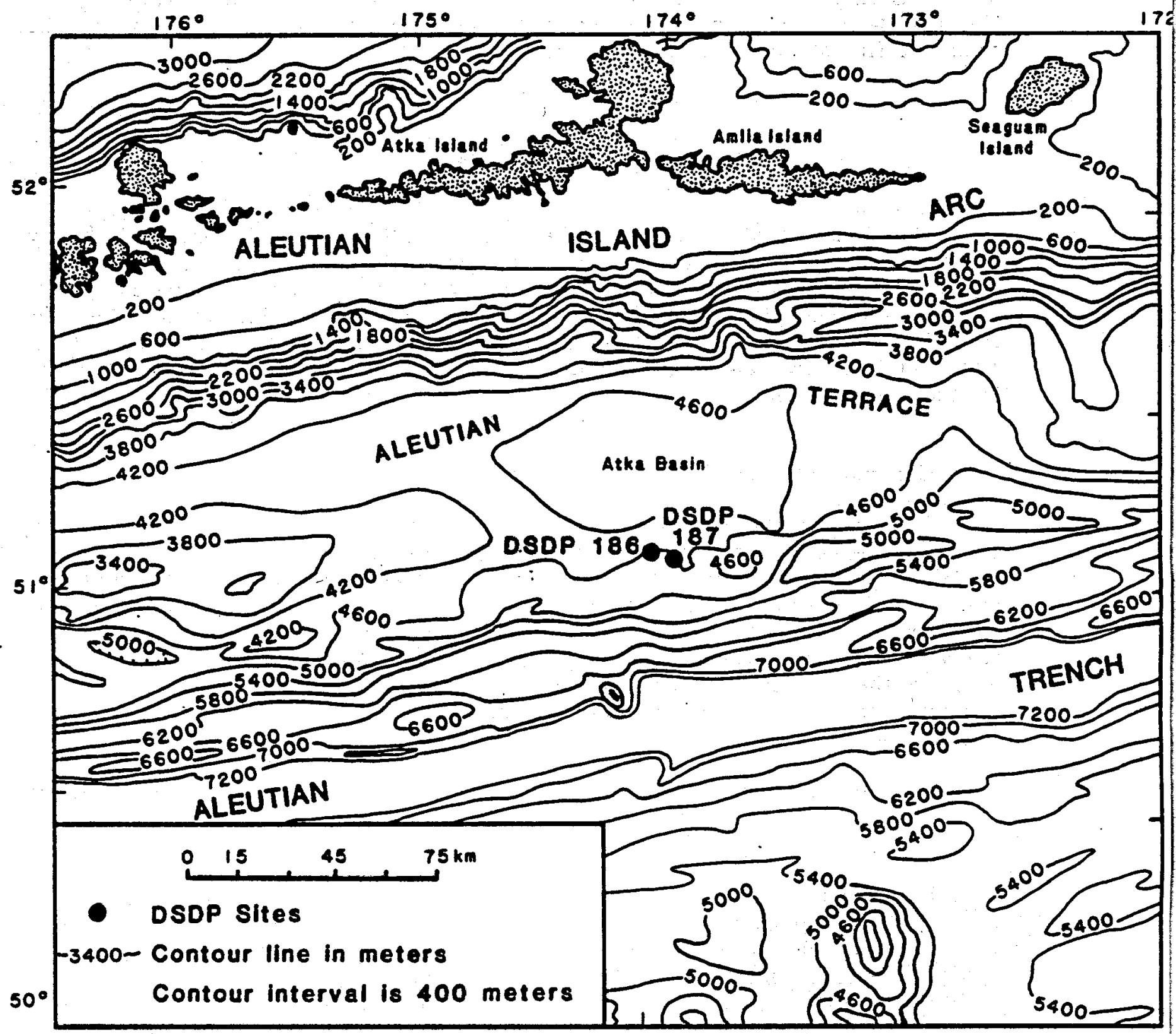

Figure 2 BATHYMETRIC MAP OF CENTRAL ALEUTIAN TRENCH, SOUTH OF ATKA AND AMLIA ISLANDS

After McCarthy and Scholl, 1985 
The geomorphological profile of the landward slope in the eastern part of the Aleutian Arc-Trench system differs from its central part by a significantly narrowed or ultimately a lack of a ponded terrace (e.g. at the longitude of Kodiak Island). The slope constitutes a relatively uniform area dipping at an average angle of $6^{\circ}$.

\section{Navarin Basin}

The remoteness of this basin certainly contributed significantly to the lack of a detailed bathymetric map of the area until very recently. Although geomorphological features of the area were discussed by Russian scientists in the past (Lisitsin, 1966; Gershanovich, 1968), no detailed maps of the Navarin Basin have been published. In 1970 Scholl et al. authored a geomorphological diagram of the Zhemchug Submarine Canyon and a bathymetric map of the adjacent continental slope. Four years later (1974) Scholl and his co-workers published a map which covered the entire continental slope of the Bering Sea. Also, Pratt and Walton (1974) published a bathymetric map covering the Navarin continental shelf. Next in this series of maps was a bathymetric map of the entire Navarin Basin published by Fisher et al. (1982).

Navarin Basin (Figure 3) represents an area of great geomorphological contrasts. Generally, it encompasses three major physiological provinces such as: continental shelf, shelf break and continental slope.

The continental shelf, which encompasses approximately $100,000 \mathrm{~km}^{2}$ between the 100 and $150 \mathrm{~m}$ isobaths, is one of the flattest and widest shelves worldwide. The shelf surface dips gently at an average gradient of $0.02^{\circ}$, while the average gradient for continental shelves worldwide is $0.12^{\circ}$ (Shepard, 1963). The outer continental shelf is deeply incised by a series of canyons (Figure 3) among which the most prominent are the Navarinsky Canyon (340 $\mathrm{km}$ long), Pervenets Canyon $(125 \mathrm{~km}$ long) and Zhemchug Canyon (240 km long). Heads of all three canyons are noticeable at water depths of $150 \mathrm{~m}$. The Navarinsky and Zhemchug canyons are approximately $100 \mathrm{~km}$ wide at the shelf break while the width of the Pervenets Canyon is only $30 \mathrm{~km}$. Each of the three canyons consists of two main branches and a number of smaller tributaries on the landward side of the shelf break. The steepest walls of the canyons have been found between the $400 \mathrm{~m}$ and $3,400 \mathrm{~m}$ isobaths. In case of the Zhemchug Canyon however, the steepest slopes have been found to occur at depths of $150-200 \mathrm{~m}$. All of these canyons and the Zhemchug Canyon in particular are structurally controlled. They are incised into Neogene sediments and more lithified rocks of Paleogene age. The formation of these canyons most likely took place during the Pleistocene glacial eustatic sea level lowstand when most of the Bering Sea shelf was exposed.

Directly related to the above described canyons are large submarine ridges which constitute the seaward edge of the shelf (Figure 3). The Pervenets and Navarin ridges enclose Pervenets Canyon from the north and south, whereas Navarin and Pribilof ridges constitute flanks of the Zhemchug Canyon. According to Cooper et al. (1981) these ridges are the surface expressions of structural highs where the acoustic basement is elevated to less than $1,000 \mathrm{~m}$ below the sea floor. 


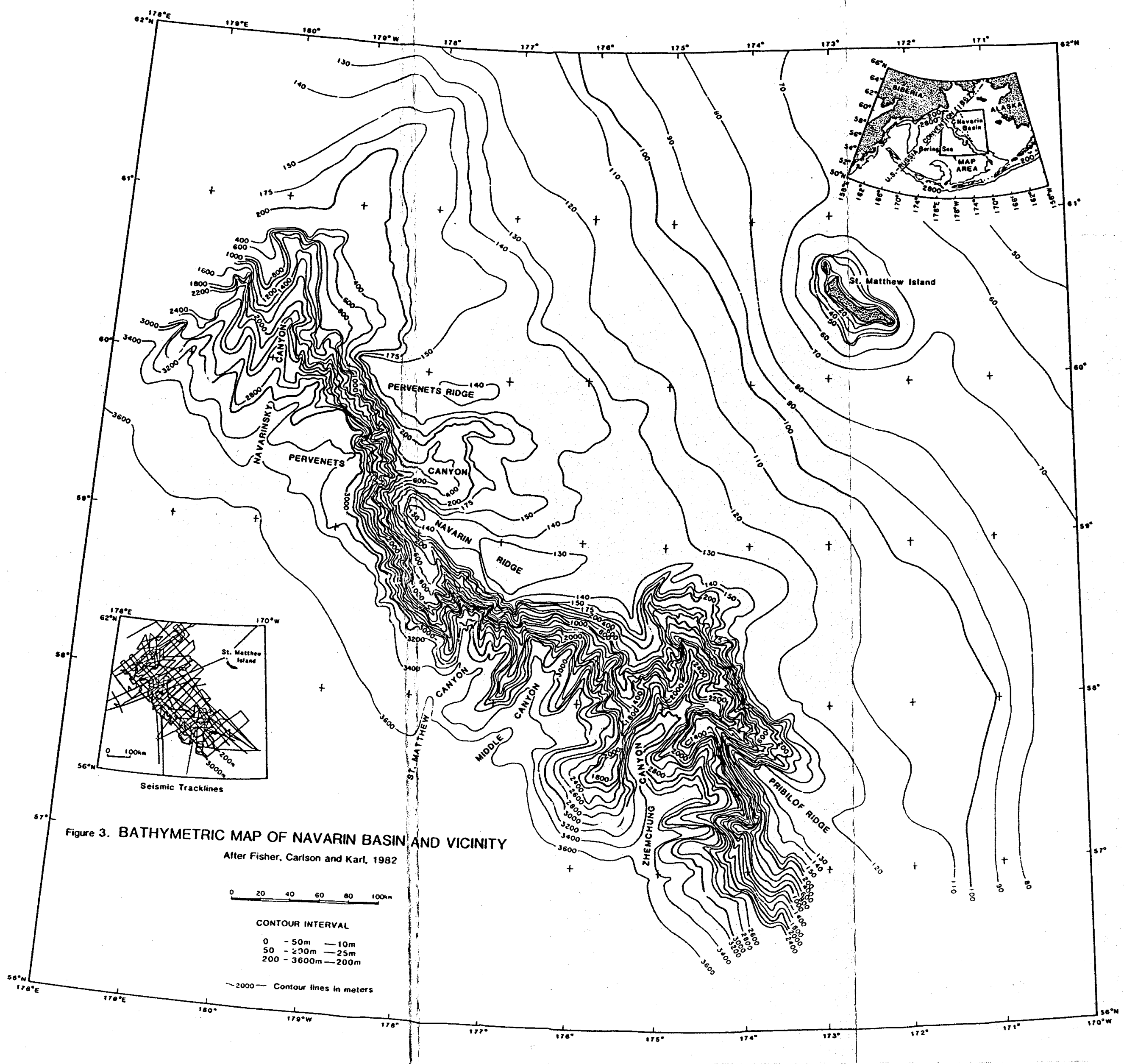


The continental rise within the Navarin Basin occupies an area of approximately $40,000 \mathrm{~km}^{2}$. It starts at the base of the slope which coincides with the $2,800 \mathrm{~m}$ isobath and continues beyond the $3,600 \mathrm{~m}$ isobatil delineating the margin of the abyssal plain. The width of the continental rise varies from $25 \mathrm{~km}$ northwest of the Zhemchug Canyon to over $100 \mathrm{~km}$ in the area adjacent to the mouth of the Navarin Canyon. The sea floor at the continental rise displays gradients ranging from $0.5^{\circ}$ in the areas adjacent to the canyon mouths, to $1.8^{\circ}$ off the two major ridges. Deep-sea channels crossing the continental rise apparently can be related to the submarine canyons dissecting the continental slope.

\section{Norton Basin}

Geomorphology of the sea floor in the Norton Basin displays a simple pattern. As a part of the northern Bering Sea, it represents a fragment of that flat and broad shallow epicontinental shelf. Consequently, no major forms are present in the geomorphology of the area. The water depths over most of Norton Basin do not exceed $30 \mathrm{~m}$.

\section{Plate Tectonic Framework}

Despite the significant progress made recently in developing the unified global plate tectonics theory, many important questions in its application to various plate margins still remain. The Bering Sea and Aleutian Trench represent one such complex margin. Most of the difficulties in the reconstruction of the development of the Bering Sea region stem from the fact that probably the combination of the subduction of the oceanic lithosphere as well as its transform motion has taken place there. Also the mechanism which led to the replacement of the ancestral trench with the younger Aleutian Trench is still not clear.

Based on the existing geophysical and geological data, several models of tectonic evolution have been postulated in recent years. They are briefly reviewed below.

\section{The Aleutian Trench}

The Aleutian Trench is a product of interaction between the Pacific and North Atlantic plates (Figure 1). The plate motion which describes the developing interaction between these plates has been suggested by Pitman and Hayes (1968) and by Grow and Atwater (1970).

Pitman and Hayes' model (1968) calls for an initial triple junction of migrating ridge axes in the northeast Pacific during the late Cretaceous. An east-west trending ridge (i.e. an ancient Kula ridge), together with a since fully subducted Kula plate, migrated toward an ancient Aleutian Trench. The Kula ridge which vanished in the subduction zone during the Paleocene left behind the newly formed Pacific plate. According to the Pitman and Hayes 
model, the Pacific plate was attached to the North American plate (Bering Sea and southwestern Alaska) but both plates may have moved together relative to the earth's spin axis. After the Kula ridge and triple juncture reached the trench in Paleocene or early Eocene the Kula ridge was stifled. As a result the underthrusting at the Aleutian Trench was altered and the Pacific plate was welded to the North American plate. In late and early Miocene, the direction of relative plate motions changed to a north-northwest/ south-southwest direction which coincided with the opening of the Gulf of California (Hayes and Pitman, 1970). At this time the Aleutian Trench was reformed and underthrusting along the trench was reactivated.

The discontinuous motion between the Pacific and North American plates in Pitman and Hayes' model agrees with the paleontologic data from sediment samples collected in the North Pacific (Scholl et al., 1971). Paleontologic dating of the drill samples revealed that the fossil-bearing fan underlying the Aleutian abyssal plain in the northeast. Pacific consists of turbidite beds of middle Eocene to late Oligocene age. The probable source of these sediments is continental Alaska (Mammerickx, 1970).

Similarly, analysis of sediment samples from DSDP Site 192 (northwest Pacific; Figure 1) indicates late Miocene as the most probable time of deposition. These data seem to prove that only a limited amount of Cenozoic plate motion $(1,000 \mathrm{~km})$ between the Pacific and North American plates actually took place.

Objecting to the discontinuous plate motion model of Pitman and Hayes, Francheteau et al. (1970) and Sclater and Jarrard (1971) came up with paleomagnetic evidence which showed a large northward movement (relative to the earth's spin axis) of the Pacific plate since Cretaceous time.

Considering the paleomagnetic data, Grow and Atwater (1970) proposed a plate model with continuous motion between the Pacific and North American plates during the Cenozoic era. In their model, Grow and Atwater retained the triple junction ridge configuration used by Pitman and Hayes (1968) and placed the collision between the Kula ridge and Aleutian Trench at $30 \mathrm{~m} . \mathrm{y}$. ago (Oligocene; Figure 4), not in the Paleocene or Eocene as in the previous model. The significantly increased volcanism in the Aleutian Trench during the early Tertiary, Grow and Atwater related to subduction of the Kula ridge at the Aleutian Trench. The continuous motion model also implies continuous underthrusting along the Aleutian Trench by the Pacific plate after subduction of the Kula ridge. Thus, the model of Grow and Atwater implies the subduction of several thousand kilometers of the Pacific plate during Cenozoic time. However, the presence of thick masses of terrigenous sediments in the northwest and northeast has not been suggested by JOIDES data. The studies of seismic reflection lines from the eastern part of the Aleutian Trench led Kvenvolden and yon Huene (1985) to the conclusion that a 3,000 $\mathrm{m}$ thick sheet of sediment is being subducted at a rate of $60 \mathrm{~km}$ per million years along the eastern Aleutian Trench system.

\section{Tectonic Evolution of the Bering Sea}

All tectonic models for the evolution of the Bering Sea suggest oblique collision between the ancient Kula (?) and North American plates (Figure 4) along the Bering Sea margin prior to the formation of the Aleutian ridge 


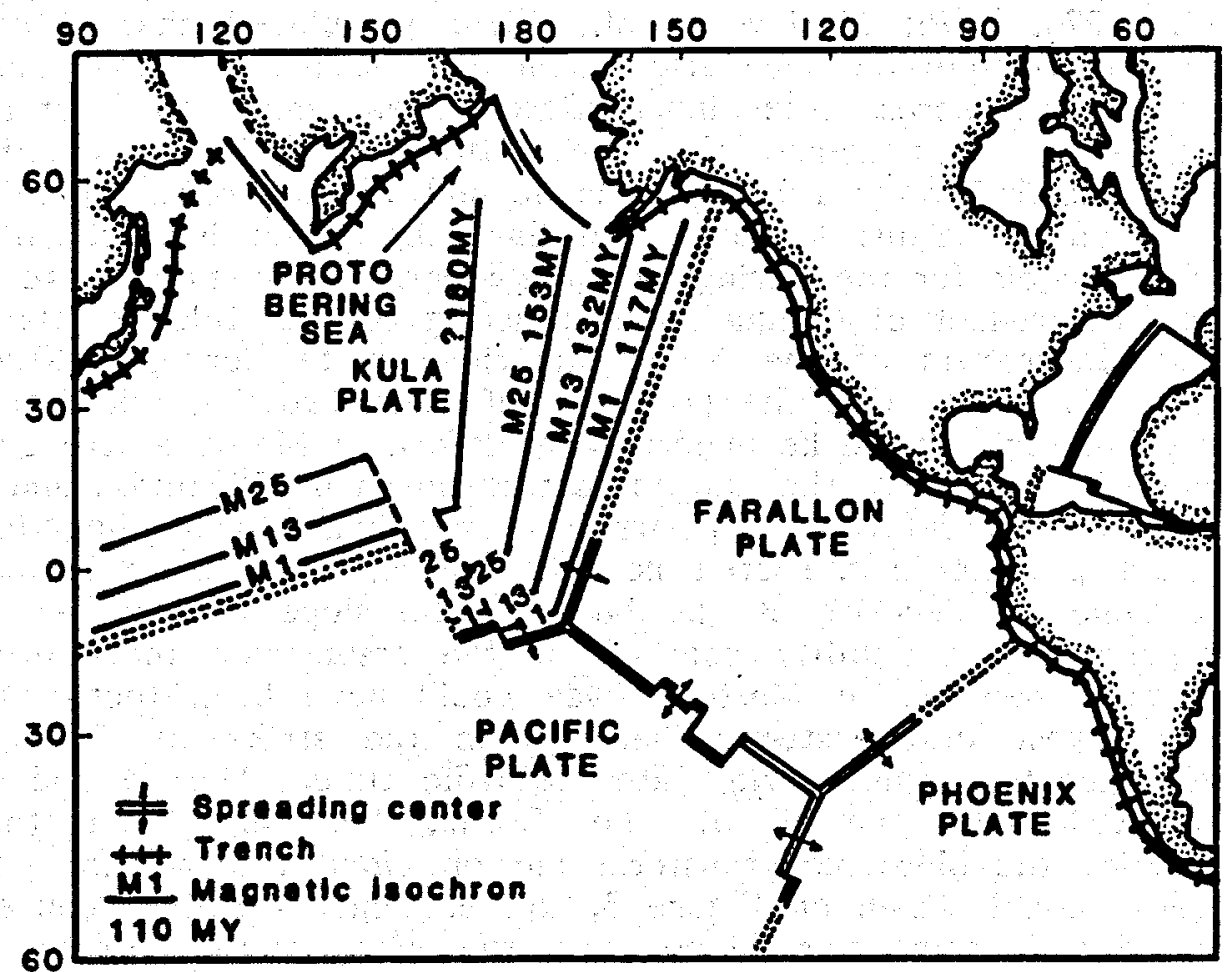

Figure 4 RECONSTRUCTION OF PLATE LOCATIONS BASED ON PALEOMAGNETIC DATA

After Larson and Pitman, 1972 
(Scholl and Buffington, 1970; Scholl et al., 1975; Marlow et al., 1976; Patton et al., 1976). This assumption is based mainly on the configuration of volcanic belts and magnetic anomalies in the region. Several authors (Patton et al., 1974, 1976; Marlow et al., 1976) postulated that a belt of closely spaced high-amplitude magnetic anomalies extending from southern Alaska northwestward across the inner Bering Sea shelf to eastern Siberia is indicative of the presence of a magmatic arc. This arc would be composed of Mesozoic and lower Tertiary volcanic and plutonic rocks which are partially exposed on the Saint Matthew and Saint Lawrence islands. In most of the tectonic models for the Bering Sea, the mentioned magmatic arc is considered to be the product of oblique underthrusting of the Kula (?) plate beneath the Bering Sea margin of the North American plate during Mesozoic and early Tertiary (?) time. Had the processes of underthrusting taken place, the outer Bering Sea shelf should be underlain by deformed Mesozoic trench and oceanic sediments accreted to the margin as was shown by Dickinson and Seely (1979). Until now such deformed deposits have not been found, implying that either they are present in the area not sampled or are deeply buried beneath the thick Cenozoic deposits at the base of the slope (Marlow et al., 1979). A third suggested possibility consists of the assumption that deformed oceanic and trench deposits of Mesozoic age could have been tectonically rafted to the northwest into eastern Siberia when the strike-slip faulting or oblique convergence took place during late Mesozoic time. Marlow and Cooper (1980) constructed their model of the Bering Sea margin tectonic evolution introducing the Mesozoic transform motion along the margin. In Marlow and Cooper's model shown on Figure 5, the element of oblique convergence at the Bering Sea margin is retained. At the same time, authors of the model assumed that:

the evidence for plate convergence in the form of deformed and accreted oceanic and trench deposits may be buried beneath the slope.

Further assumption accommodated by Marlow and Cooper about rafting of the deformed trench sediments along the margin is based on a discussion presented by Fitch (1972). The latter author postulated that it is possible for obliquely underthrust margins to move by long segments of the margin parallel to a trench similarly to simple transform margins.

Another quite interesting model of tectonic evolution of the Bering Sea margin has been proposed by Patton Jr. (1980). According to this model, the Bering Sea margin was obliquely underthrust by the Kula plate prior to 80 m.y. ago (middle-late Cretaceous). During the period of time 80-60 m.y ago, the oroclinal bending of western Alaska probably caused clockwise rotation of the Bering Sea margin. This event originated a change in plate motion from oblique underthrusting to strike-slip motion along the juncture between the North American and Kula (?) plates. As a result the subduction zone of the Bering Sea margin evolved into a transform fault zone. - Further oroclinal bending of the margin led to "blockage" of the transform fault zone and to formation of the present subduction zone, the Aleutian Trench south of the ancient Bering Sea margin underthrust zone. This event probably trapped part of the ancient Kula (?) plate in between the two subduction zones (Shor, 1964; Menard, 1967). 


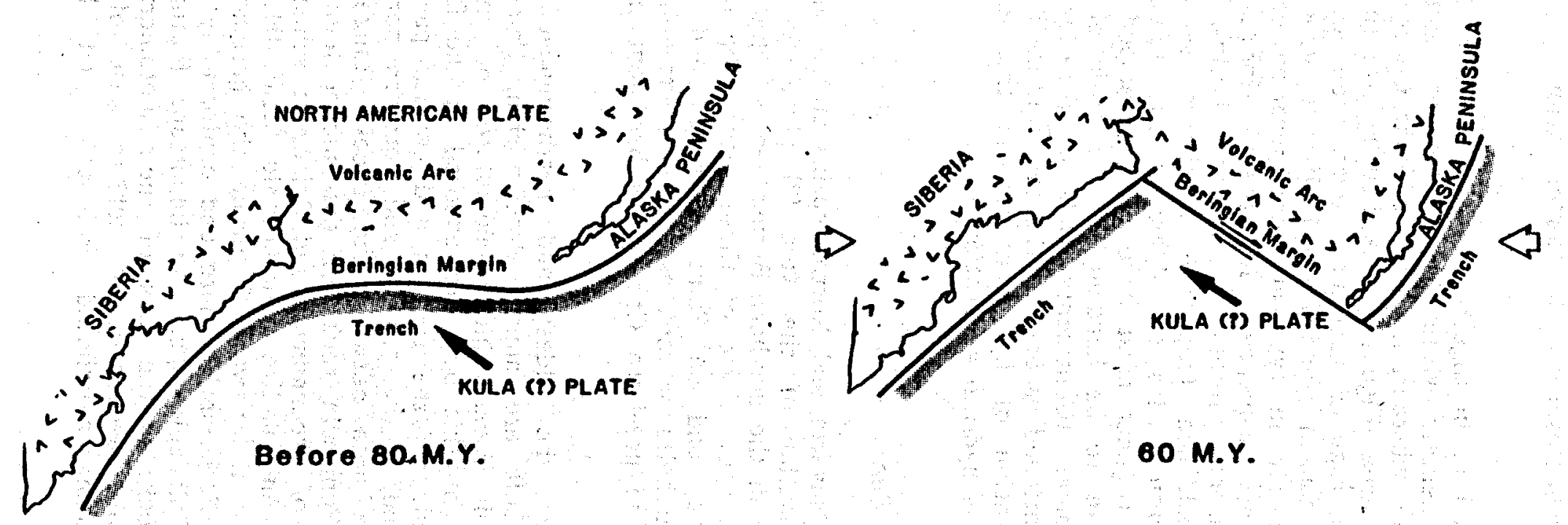

Prlor to 80 m.y.. margin was obllquoly underthruot by Kula (?) plate. Botween 80 and 60 m.y., orocllnal bending of western Alaska and subsequent clockwlse rotatlon of maroln resulted in change in plate moflon to fransform or Strike-ollp movemont botween North American end Kula (2) plates.

Figure 5 GENERALIZED MAPS OF LATE MESOZOIC AND EARLY TERTIARY
PLATE MOTIONS ALONG BERINGIAN MARGIN - PATTON'S MODEL

After Marlow and Cooper, 1980 


\section{Structural Setting of the Navarin Basin and the Norton Basin}

The Navarin Basin and the Norton Basin together with the Anadyr Basin are the largest structural depression centers within the continental shelf of the Bering Sea. Only two others, the substantially smaller Saint George and Briston Bay basins, occur in the same area (Figure 1). Although formation of all these basins resulted from common regional tectonic events, their location relative to major tectonic elements caused sometimes significant structural variations. These differences are mainly in type and configuration of the basement, thickness of the sedimentary sequences, and their deformations. Subsequently considering contemporaneous formation of the basins, and significantly different rates of subsidence (e.g. the maximum sediment thicknesses in the Navarin and Norton basins are $4,000 \mathrm{~m}$ and $12,000 \mathrm{~m}$ respectively), various sedimentological regimes must have been developed. The lithological aspects however, still have to be handled on the basis of very scanty data available in the public domain (Continental Offshore Stratigraphic Tests - COST). All of the above mentioned aspects of the sedimentary basins play a primordial role in the generation of hydrocarbons and thus create necessary conditions for hydrocarbon gas hydrate generation.

\section{Basement in the Northern Bering Sea}

The depositional history of the Navarin and Norton basins started during late Late Cretaceous, when the cessation of the Kula (?) plate occurred. Therefore, the basement of the basins in the northern Bering Sea is delineated by rocks of pre-late Late Cretaceous age. Some of these rocks crop out in northeast Siberia, in western Alaska, and on Saint Lawrence and Saint Matthew islands. Three broad geologic belts or rock assemblages extending in west and east directions constitute the pre-Late Cretaceous basement in the northern Bering Sea:

a. The miogeoclinal belt is the oldest and northernmost rock assemblage. Rocks in this belt are mainly Precambrian, Paleozoic and lower Mesozoic nonvolcanic rocks which accumulated on ancient continental crust. The rocks of this belt are exposed in the Brooks Range on, the Seward Peninsula, in the eastern and central parts of the Saint Lawrence Island, and in the eastern and northern parts of the Chukotsk Peninsula. The area between the Brooks Range and eastern and central Seward Peninsula rocks of the miogeoclinal belt consists mainly of a complex of Precambrian and Paleozoic schist and marble of greenschist and of amphibolite metamorphic facies (Hudson, 1977). In the western part of the Seward Peninsula the basement is built of a thick sequence of Precambrian slate and conformably overlying carbonate rocks of a Paleozoic age. An important feature of these carbonate and slate rocks is the lack of their metamorphism compared to the corresponding sequences of schists east of the described area. Similar unmetamorphosed Paleozoic and lower 
Mesozoic carbonate and nonvolcanic rocks have been found on the Chukotsk Peninsula (Parfenov et al., 1979) and on the Saint Lawrence Island (Patton and Csejtey, 1971, 1980). The presence of pre-Cretaceous miogeoclinal rocks on Saint Lawrence Island, which lies at a much lower latitude than the Brooks Range or the Chukotsk Peninsula, is often considered as proof of the miogeosynclinal belt deflection to the south. According to Patton and Tailleur (1977) this deflection occurred as a consequence of east-west compression and crustal shortening during late Cretaceous or early Paleogene time.

b. The Okhotsk-Chukotsk volcanic belt probably evolved as a result of the convergence and subduction of the oceanic lithosphere (Kula Plate? under the Mesozoic Bering Sea continental margin and eastern Siberia (Scholl et al., 1975; Marlow et al,, 1976). The volcanic rocks of this belt have been documented in the Yukon-Koyakuk province in western Alaska, in western Saint Lawrence Island and Saint Matthew Island in the Bering Sea, as well as in southern Chukotsk Peninsula in eastern Siberia. In the Yukon-Koyakuk province the oldest rocks are marine andesitic volcanics of Early Cretaceous age. The thickness of this series is approximately $1,500 \mathrm{~m}$. The rock series is overlain by a middle Cretaceous sequence of volcanic graywacke and mudstone which may reach a thickness of $8,000 \mathrm{~m}$. Paralic deposits of coal-bearing strata have been found in the upper sections of the middle Cretaceous sequence. Volcanic rocks outcrop in the western part of Saint Lawrence Island while composing almost the entire suite of exposed bedrock on Saint Matthew Island. On the Siberian side, the belt of middle Cretaceous (Albanian-Cenomanian) volcanic rocks extends from the southern Chukotsk Peninsula nearly to the Chaun Gulf to the north and to the Sea of Okhotsk to the south (Filatova, 1979). Various structural studies showed intensely deformed volcaniclastic rocks of the volcanic belt whereas coeval rocks in Siberia are much less deformed.

Magnetic studies in the north Bering Sea region (Verba et al., 1971; Marlow et al., 1976) revealed that a broad magmatic belt extends from southwestern Alaska to the Gulf of Anadyr. It is about $200 \mathrm{~km}$ wide close to the Siberian coast. The delineation of the belt somehow becomes vague toward the east as it widens to $600 \mathrm{~km}$ along the west coast of Alaska. This change probably reflects the type of rocks building up the volcanic belt. It is composed exclusively of volcanic rocks in Siberia while more nonmagnetic rocks are intercalated on the Alaskan side of the belt. The isotopic analysis of potassium-argon from the rocks of the Cretaceous volcanic belt shows their age to range from 110 to 75 m.y.

c. The forearc belt is composed mainly of Mesozoic sedimentary rocks with an insignificant fraction of crystalline volcanic rocks. The rocks of this belt are known mainly from the Koryak- Anadyr region in Siberia. These rocks are represented by deep water flysch deposits with interbedded mafic volcanics of upper Jurassic and lower Cretaceous age as well as the upper Cretaceous and lower Tertiary shallow-water and nonmarine deposits. Similar rocks were recovered 
from the sea bottom continental slope in the Bering Sea. These facts enabled Marlow et al. (1979) to suggest the presence of basement rocks of the forearc belt under the outer edge of the Bering Sea margin, southwestward from Siberia.

\section{Structural Features of the Navarin Basin}

The structural features of the Navarin Basin geology are still insufficiently known despite studies actively conducted in the area since 1970 . Approximately $1,000 \mathrm{~km}$ of single-channel seismic reflection records, using a sparker sound source, were collected in 1970 within the Navarin Basin. Since that time most of the multi-channel seismic data over this area were obtained by numerous expeditions carried out by the U.S. Geological Survey.

Structural maps of the Navarin Basin based on the seismic, gravimetric and magnetic data revealed the actual presence of three subbasins separated by ridges and trending in a northwest direction (Figure 6). The northernmost and largest subbasin encompasses an area of $10,350 \mathrm{~km}^{2}$ and contains a 12,000 to $15,000 \mathrm{~m}$ thick sedimentary sequence. In the northwestern part of the subbasin larger anticlinal forms (up to $15 \mathrm{~km}$ across) are present. It is believed that these forms have diapiric origin (Marlow, 1979). The central subbasin is the smallest of the three subbasins. Its area is approximately $1,500 \mathrm{~km}^{2}$. The third and southernmost subbasin represents an elongated, approximately $200-\mathrm{km}$ long trough. This subbasin is filled with more than $11,000 \mathrm{~m}$ of sediment. Normal faults and structures associated with growth have been identified along the subbasin's flanks.

In all, the Navarin Basin does not seem to have a uniform crustal structure. While the northern subbasin is a wide, deeply crustal downwarp, the central and southern subbasins of the Navarin Basin represent a series of elongated grabens parallel to the outer shelf of the Bering Sea (Marlow et al., 1981). The Navarin Basin is flanked on its eastern side by the OkhotskChukotsk volcanic arc while it is underlain by Mesozoic rocks which constitute the basement.

Two interpretative drawings of the seismic reflection profiles from the northwestern Bering Sea margin presented by Marlow et al. (1981) well illustrate the known structural features of the Navarin Basin (Figures 7, 8, and 9). Superimposed gravity profiles provide additional data on geometry of the basement.

Profile A-B (Figure 8). In the southwestern section, which dissects the eastern edge of the Aleutian Deep Sedimentary Basin, acoustically well defined basement is overlain by 4,000 - 5,000 $\mathrm{m}$ of undeformed sediments. Under the lower and middle sections of the continental slope, seismic resolution of the strata proved to be very poor. Only scattered and discontinuous reflections have - been obtained from these areas. Tracing of the basal reflectors can be resumed from the upper middle continental slope toward the shelf. The basement under the upper continental slope and beneath the outer shelf displays considerable variations in relief. due to broadly folded Jurassic and Cretaceous rocks. Further in a northeastern direction the basement becomes flat and gently dips toward the deepest axial parts of the Navarin Basin where thickness of the sediment reaches $12,000 \mathrm{~m}$. The sedimentary strata lie unconformably on the basement. Analyses of rock samples dredged 


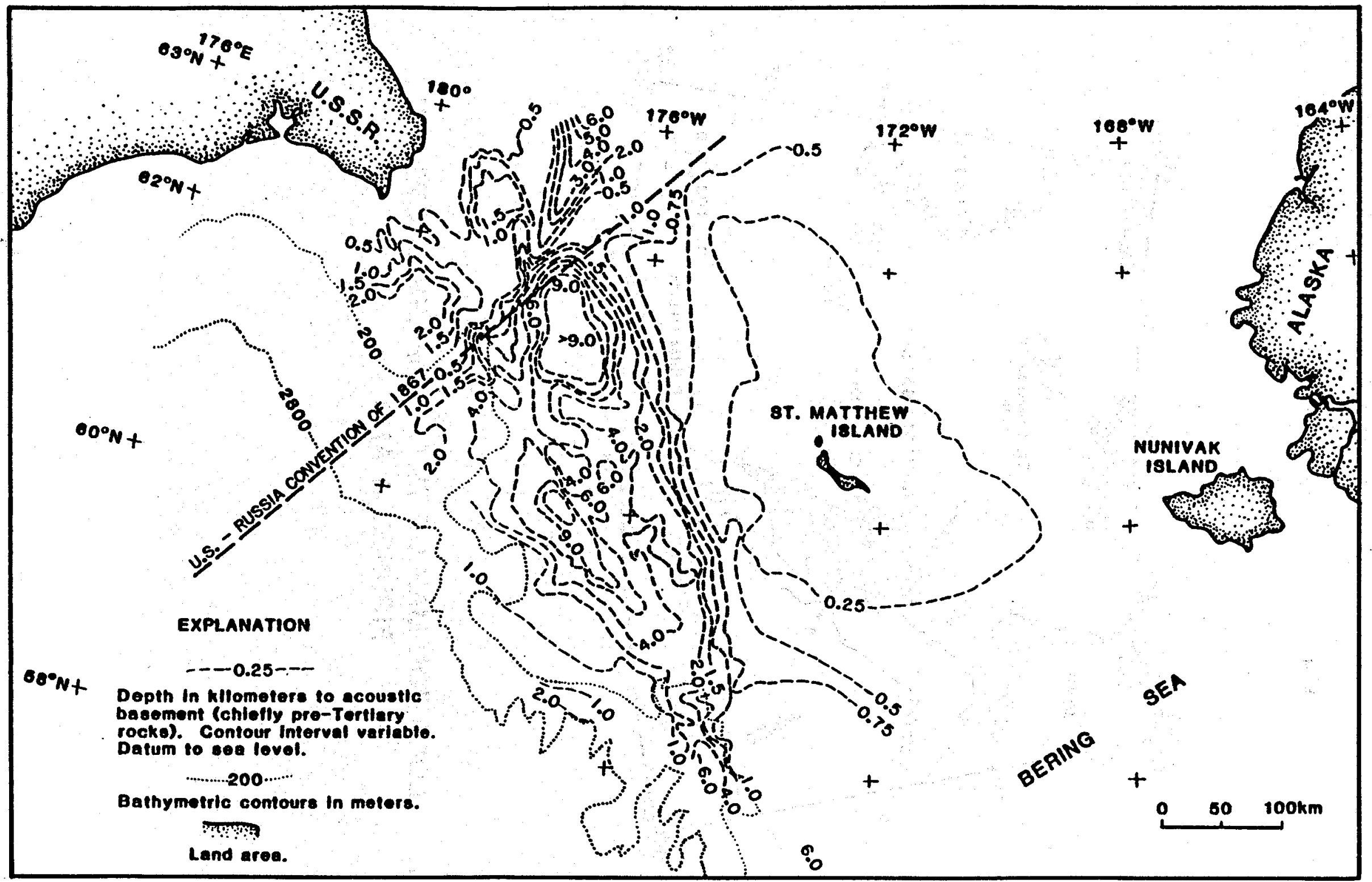

ปี

Figure 6. STRUCTURE CONTOUR MAP OF ACOUSTIC BASEMENT IN THE NAVARIN BASIN 


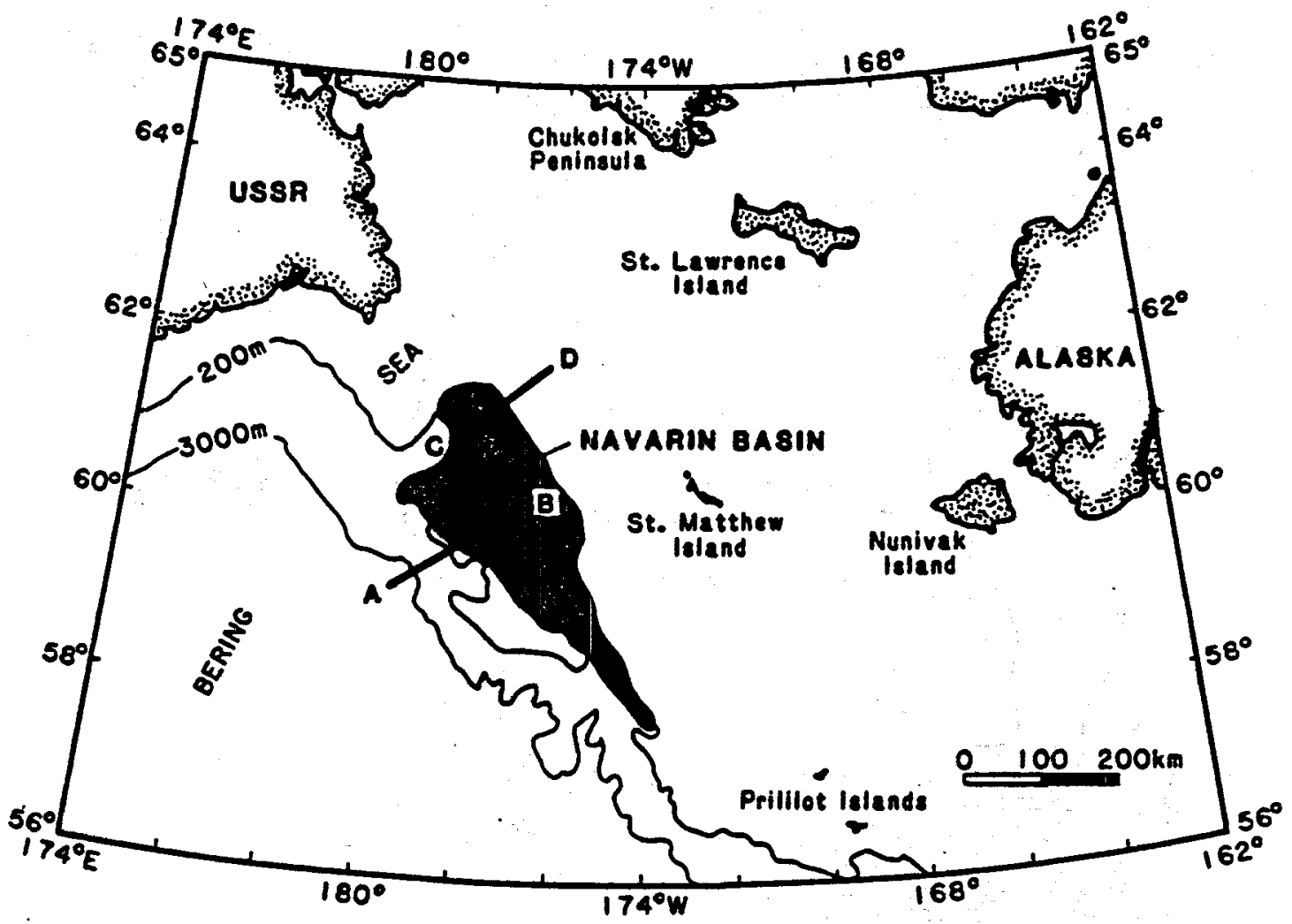

Figure 7. LOCATION MAP OF TWO PROFILES SHOWN ON FIGURES 8 AND 9 
A
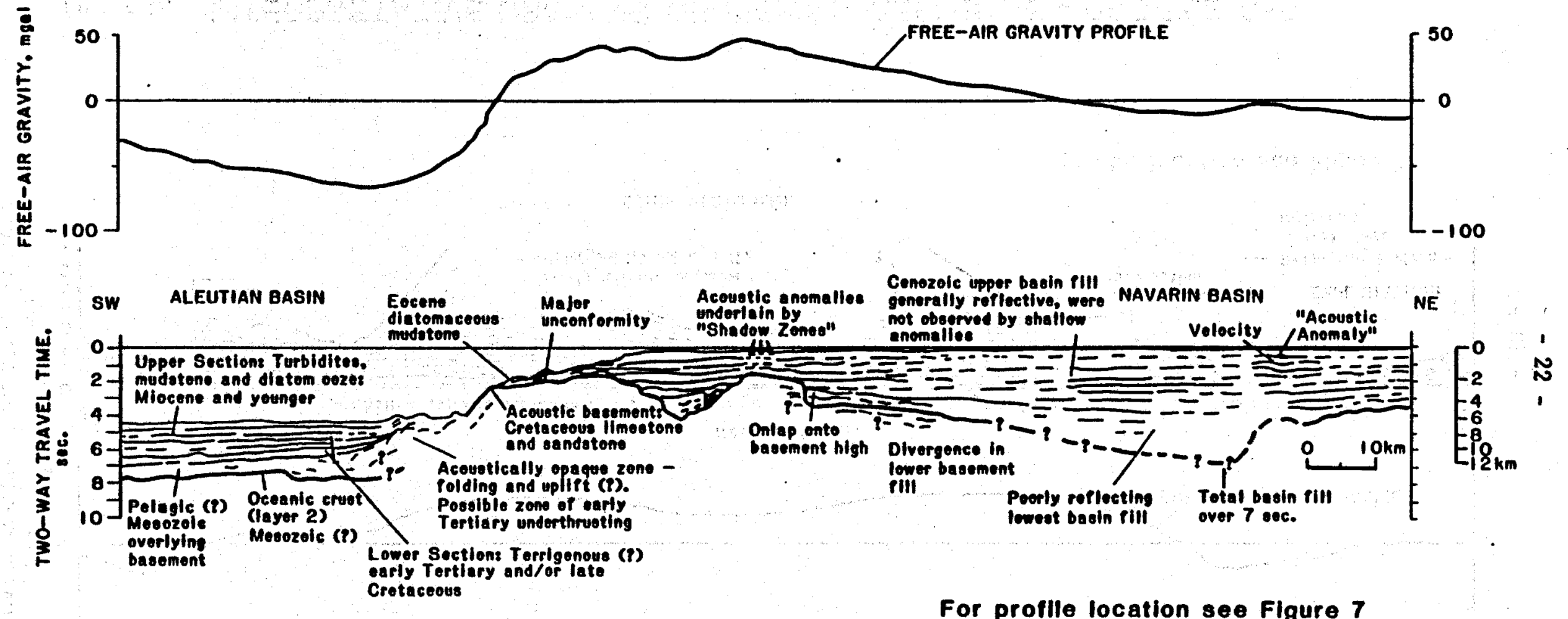

Figure 8. INTERPRETATIVE DRAWING OF SEISMIC-REFLECTION PROFILE A-B ACROSS THE NAVARIN BASIN PROVINCE

After Marlow et al., 1981 

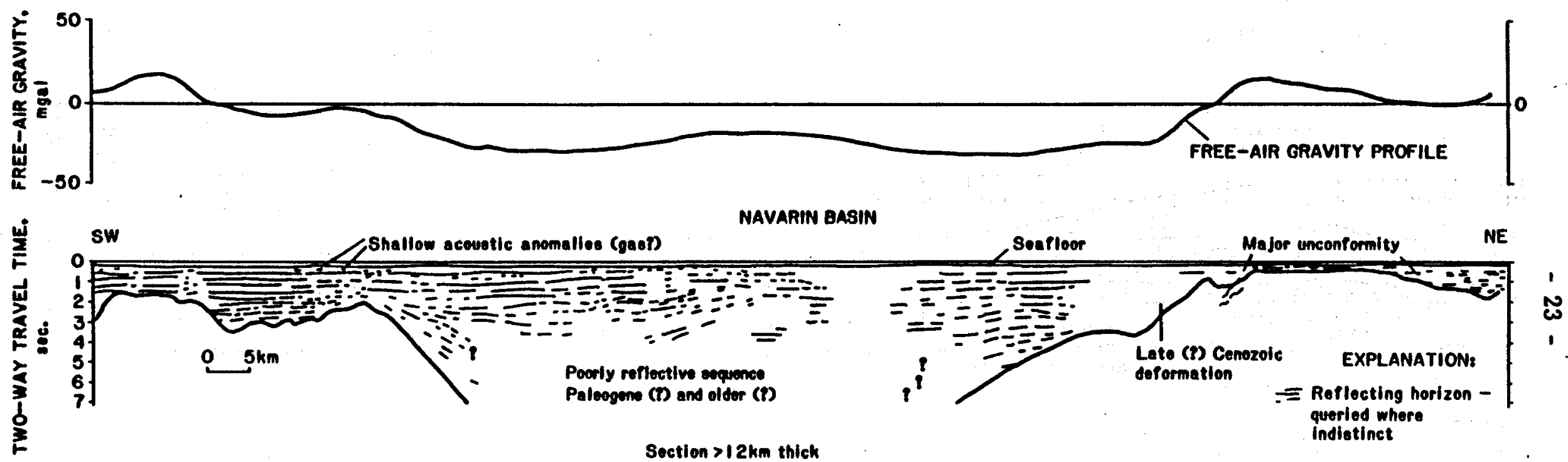

Section $>12 k m$ thick

For proflle location sẹe Figure 7

Figure 9. INTERPRETATIVE DRAWING OF SIESMIC-REFLECTION PROFILE C-D ACROSS THE NAVARIN BASIN

After Marlow et al., 1981 
in various parts of the basin showed that the upper $3,000-4,000 \mathrm{~m}$ of sedimentary sequences in the Navarin Basin are younger than early Eocene where the strata near the base are of Cretaceous age (Marlow, 1979). Seismic reflections from the upper strata of the basin appear to be horizontal and continuous with the exception of "wipe out" zones which probabiy result from shallow accumulations and which could potentially create traps for migrating hydrocarbons and are more likely to occur in sections closer to the basement. Such traps are concelvable in anticlines over elevated sections of the basement as well as in connection with growth faults. A strong probability of growth fault occurrence was indicated by several authors (Marlow et al., 1981). Relatively rapidly subsiding Navarin subbasins produced pinching-out strata which also represents good potential for the accumulation of hydrocarbons.

Profile C-D (Figure 9). This profile displays structural features in the northernmost Navarin Basin. The width of the basin along the profile is approximately $105 \mathrm{~km}$. Well defined basal reflectors on the flanks of the basin disappear in the central section of the profile where the basement depth reaches over $12,000 \mathrm{~m}$. The upper sedimentary sequences with broad and gentle folds are well defined seismically in the flanks of the basin. The corresponding seismic reflectors in the central section of the basin lose their continuity due to the "wipe-out" zones. The omnipresence of the latter zones, representing sediments saturated with hydrocarbon gas, has an important bearing on the potential gas hydrate occurrence in the area, as will be explained in later chapters of this report. Seismic reflectors from the upper sediments within the central basin reveal wide and gentle deformations of the strata. In the southwest flank of the Navarin Basin there is noticeable divergence between middle and lower sedimentary strata which may be interpreted as angular unconformity. In most of the profile where the basement is acoustically well defined, it is unconformably overlain by the sediments. The lower sections of the basin's fill did not produce well defined acoustic horizons. The most probable cause of such poor seismic resolution of this sector is the presence of coarse clastic material deposited at early stages of the Navarin Basin's formation.

Since this profile is similar to Profile $A-B^{\prime}$, a variety of structural as well as stratigraphic traps are likely to be present.

Faults appear to be frequent structural components of the two southern basins in the Navarin Basin. Their distribution is not adequately known as they may have an important role in the delivery of thermogenic hydrocarbon gas to the gas hydrate zones. Such a relationship between fault systems and hydrocarbon gas hydrates was indicated by Mathews and von Huene (1985) in reference to DSDP Site $\mathbf{5 7 0}$ offshore of Guatemala.

The existing seismic, gravimetric, and magnetic data show that faults in the Navarin Basin strike predominantly in northwestern and southeastern directions, thus following the main structural trends of the region. The majority of these faults occur on the continental slope and outermost shelf.

\section{Tectonics of the Norton Basin}

Rocks of miogeoclinal and volcanic belts most likely form the basement underlying the Norton Basin. The problem of boundary delineation between 
these two belts in the area still remains in the field of scientific debate (Patton, 1973; Patton and Tailleur, 1977). Miller (1972) and Patton (1973) suggested that the suture between the two crustal types strikes in a southsouthwestern direction from Cape Denbigh (northeast of the Norton Basin). It is believed that Precambrian crystalline continental rocks, which underlie the miogeoclinal belt, compose the basement under most of the Norton Basin, whereas close to the Yukon delta, parts of the basin are underlain by the oceanic crust of Paleozoic and early Mesozoic age. West of the Norton Basin the location of the suture is probably marked by outcrops of ultramafic rocks on the western Saint Lawrence Island (Patton and Csejtey, 1980) and in northeastern Siberia (Parfenov et al., 1979).

The known structural features of the top of the basement in the Norton Basin have been inferred from seismic reflection and gravimetric data. The contour maps of seismic horizon A and free-air gravity shown by Fisher et al. (1982) revealed the presence of the Saint Lawrence and Stuart subbasins separated by a horst-like structure named Yukon horst (Figure 10). Yukon horst strikes in a northwestern direction from the Yukon River mouth. Saint Lawrence subbasin lies southwest of the Yukon horst whereas the Stuart subbasin is located east of the horst.

Saint Lawrence Subbasin. The north side of the subbasin is flanked by a shallow basesment platform extending from the Seward Peninsula. The southern flank of the subbasin is delineated by a major normal fault (Figure 10) which strikes in a northwest direction. The western limit of the Saint Lawrence subbasin has been placed arbitrarily along the $168^{\circ}$ meridian. The Yukon horst constitutes the eastern boundary of the subbasin. The contour map of horizon. A, which probably represents the unconformity surface between Precambrian-Paleozoic (basement) and Upper Cretaceous-lower Paleogene rocks, depicts relatively shallow depths of basement in the basin. It appears that the depths of the basement rarely exceed $3,500 \mathrm{~m}$ throughout the subbottom. A number of normal faults have been identified in the area. Most of them are located in the central-southern and central-eastern parts of the subbasin. They strike predominantly in a northwestern direction. The fault system in the area is frequently associated with graben type forms and to a lesser degree with horsts showing the extensional origin of the basin. The deepest section of the subbasin has been identified in the area close to the southern Yukon horst and near the Yukon River delta (Figure 10). The faultbounded depocenter contains approximately $5,000 \mathrm{~m}$ of sediments. Another prominent depressed area is highly noticeable in the central part of the Saint Lawrence subbasin (Figure 10). The fill in this depocenter is approximately $4,500 \mathrm{~m}$. Structural positions of the identified faults suggest their secondary origin relative to the previous subsidence of the area.

It seems that faults are considerably less frequent in northeastern and east-central sectors of the Saint Lawrence subbasin, whereas gently folded structures prevail.

Data from the free-air survey proved to be very useful in attempts at deciphering the structural configuration of the basment in the Norton Basin, particularly in marginal offshore shallow water where collection of seismic data was precluded. The gravity data confirmed the presence and depth of the described depositional basement lows as well as shoaling of the basin toward surrounding onshore areas (Figure 11). For example, north of the Yukon River delta the basement lies at a depth of 500 to 1,000 m. 


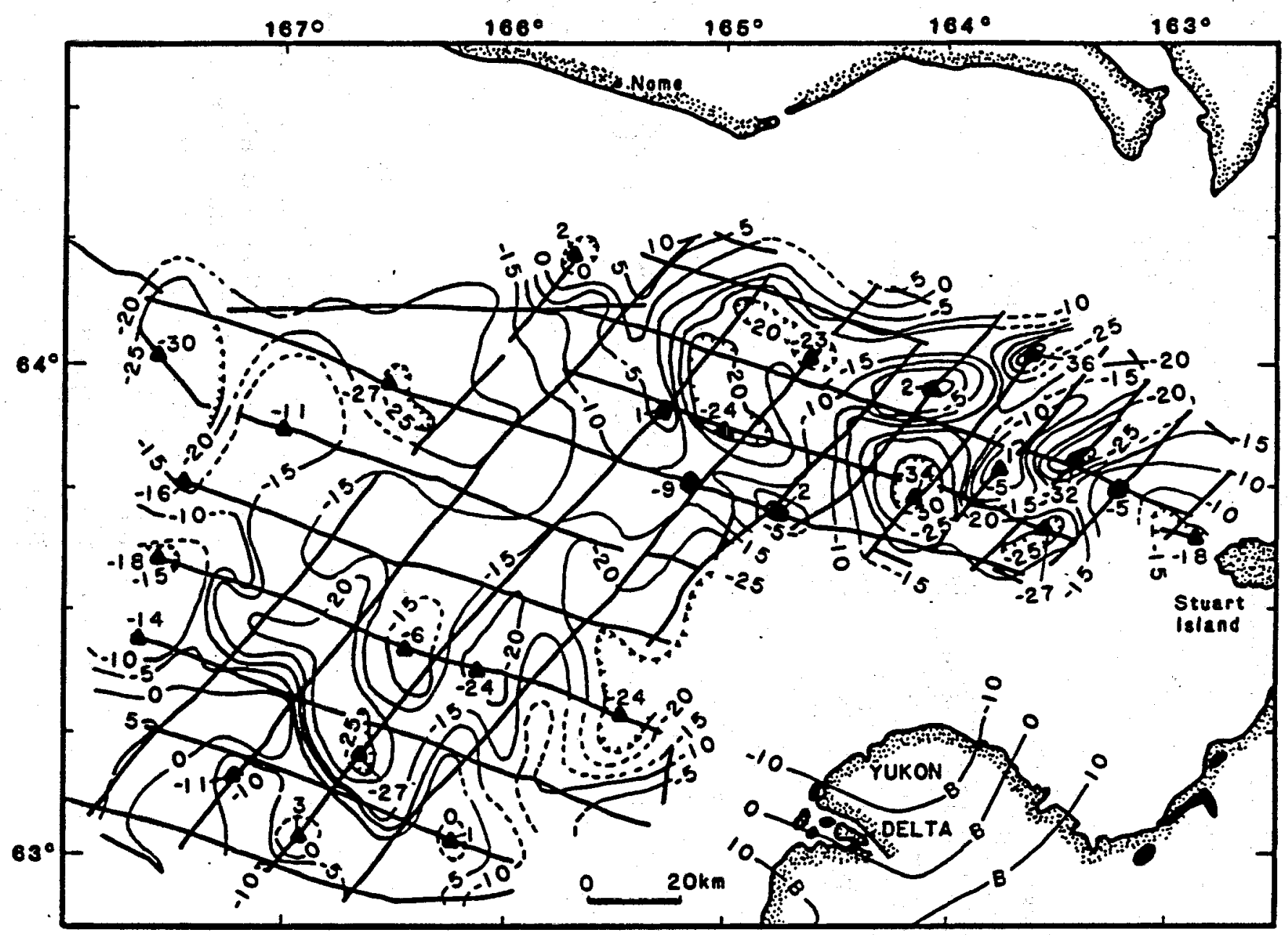

\footnotetext{
$\longrightarrow$ SHIP TRACKING

- - AIR-FREE GRAVITY CONTOUR, DASHED WHERE INFERRED, CONTOUR INTERVAL 5 mgEI

GRAVITY LOW

- EXTREMe VAlue within Closed contour

-8 - BOUGER GRAVITY. BImes (I977), CONTOUR INTERVAL 10 mgal

- CRETACEOUS VOLCANIC AND SEDIMENTARY ROCKS, Hoare end Condon (1971)
}

Figure 11. CONTOUR MAP OF GRAVITY ANOMALIES OVER NORTON BASIN (Fisher et al., 1980) AND OVER YUKON DELTA (Barnes, 1977)

Modified after Fisher et al., 1982 
Some structural relationships within the sedimentary sequences of the Saint Lawrence subbasin are well depicted in seismic sections shown on Figures $12,13,14$, and 15. The lower sedimentary strata overlying the basement display a structurally complex pattern compared with the upper sections of the profiles. This pattern is mostly caused by the faulting system which imposed a discontinuous structure of the basement and of part of the overlying sediment sequences (Figure 12). Usually on the downthrown sides of the fault, the reflections of outward thinning sediments are noticeable (seismic lines 804, 8131, Figures 12 and 13). These sediments have been interpreted as alluvial fans on a basis of assumptions that they are nonmarine rocks. Various dip angles have been reflected within the alluvial sequences which indicate changing conditions of the depositional environment. Some strong and discontinuous reflections have been recorded on many seismic sections in deep parts of the Saint Lawrence subbasin. Coal has been suggested by several authors (Fisher et al., 1982) as a probable source of these reflectors. In some cases strong reflections were associated with positive polarity which means that they could have originated from volcanic rocks or conglomerate.

The effects of faults in the Saint Lawrence subbasin range from several meters to $2,000 \mathrm{~m}$. In many instances the faults cut to depths of less than 1 sec. of two-way travel time (Figure 14). The faulting system produced elevated structures in the basement and subsequently in overlying sedimentary strata. The rellef of the latter structures decreases upward.

The upper sedimentary sections in the seismic reflection profiles do not show major disruptions or structural irregularities. The reflections are generally parallel showing only a slight downwarping feature over the entire basin.

Yukon Horst is the major elevated form of the basement within the Norton Basin. It is equally well exposed on seismic sections (Figure 14) and on gravimetric maps (Figure 11). On the east side the Yukon horst is bounded by a major fault with an of fset of almost $3,000 \mathrm{~m}$. On both downthrown sides, oblique reflections most likely represent alluvial structures. Their stratification dips downward away from the horst, and the strata converge with and terminate against the basement. Above the relatively flat top of the horst the strata show an undisturbed pattern in the form of continuous horizontal and parallel seismic reflections (Figure 14).

Stuart Subbasin is bounded on the west by the Yukon horst and on the north by a major east trending fault. While a shallow platform constitutes the eastern flank of the subbasin, the southern boundary of it has not been unequivocally established. It is known however, that the Stuart subbasin shoals significantly towards the Yukon delta where the thickness of sediment is only about $1,000 \mathrm{~m}$. The structure of the Stuart subbasin is apparently more complex compared with the western part of the Norton Basin (Figure 15). The major elevated form is the Nome horst striking in a west direction. On the north side the Nome horst is bounded by a major fault where the downthrown southern side is of fset by $4,000 \mathrm{~m}$. In the area south and east from the Nome horst the major structural elements trend in a northeastern direction (Figure 15). Except for a different structural orientation the significant feature of the Stuart subbasin is the presence of deeper sedimentary depressions. One of them is located southeast of the Nome horst (Figure 


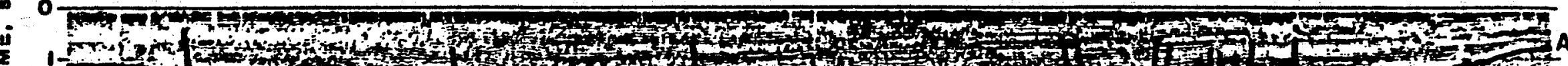

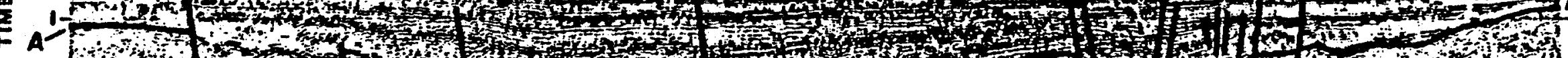

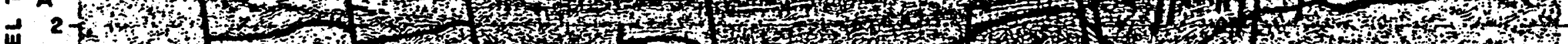

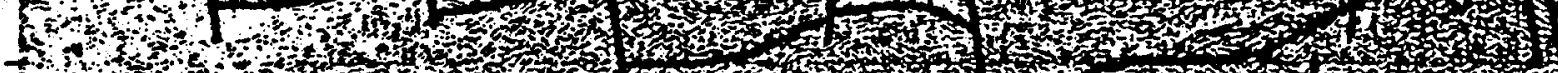

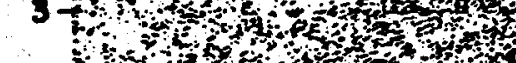

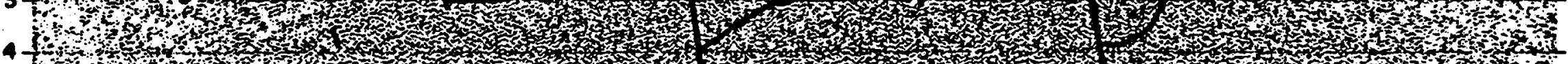

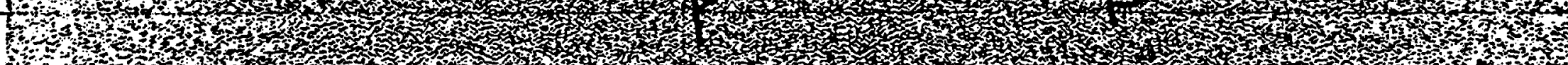

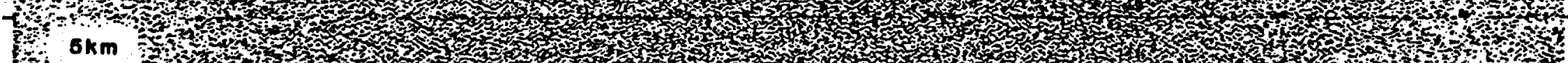

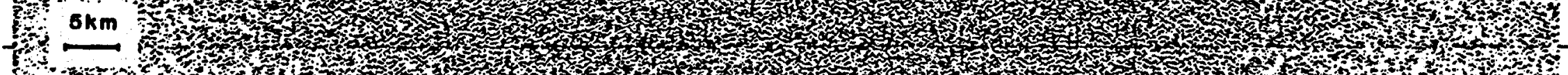
for

Track-line is shown on Figure 10

\section{LINE BI3}

WNW

ST LAWRENCE SUBBASIM

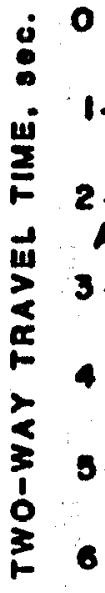
$\underset{\text { HORST }}{\text { YUKON }}$

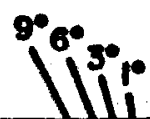

ESE

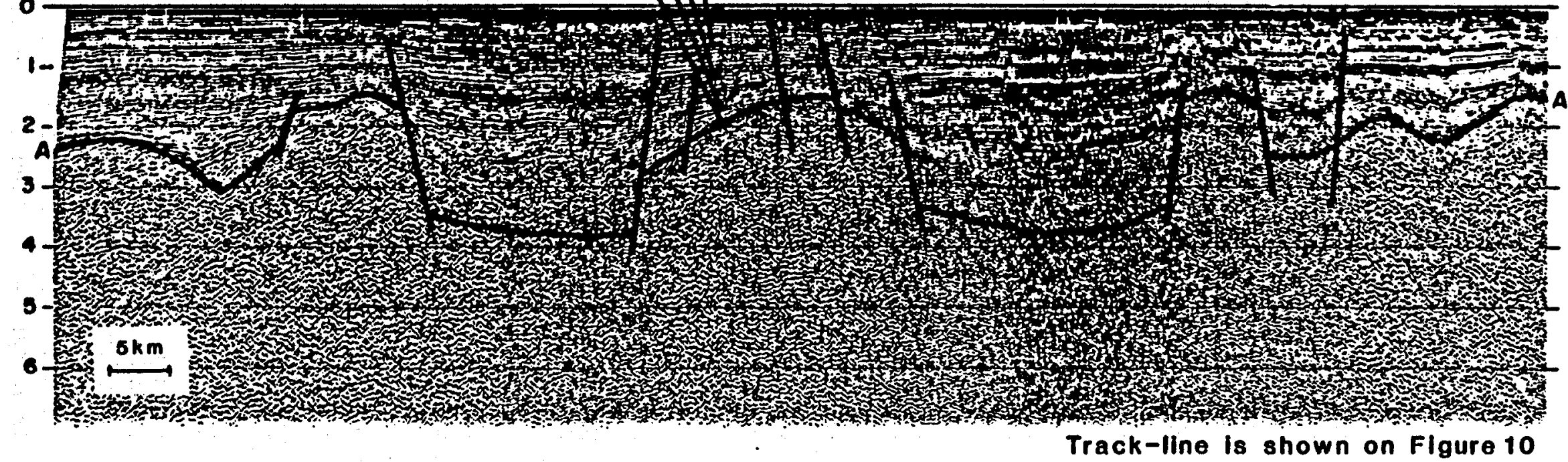

Horizon A represents top of basement rocks; some beds' dip are also indicated.

Figure 12. SEISMIC LINES FROM CENTRAL NORTON BASIN 


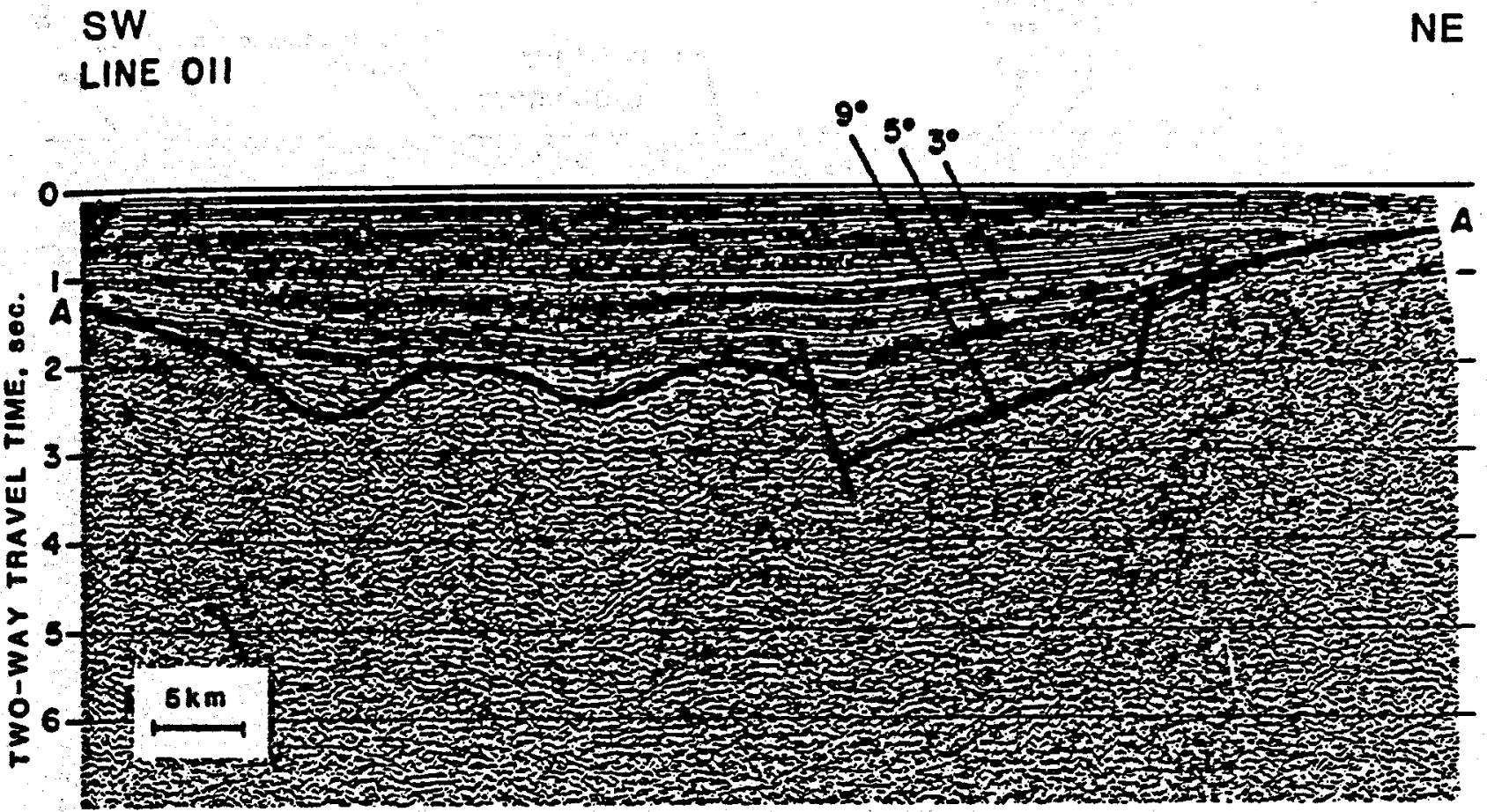

Track-line is shown on Figure 10.

Horizon A represents top of basement rocks; some beds' dips are also indicated.

Figure 13. REGIONAL SEISMIC SECTION THROUGH WESTERN NORTON BASIN

\author{
After Fisher et al., 1982
}




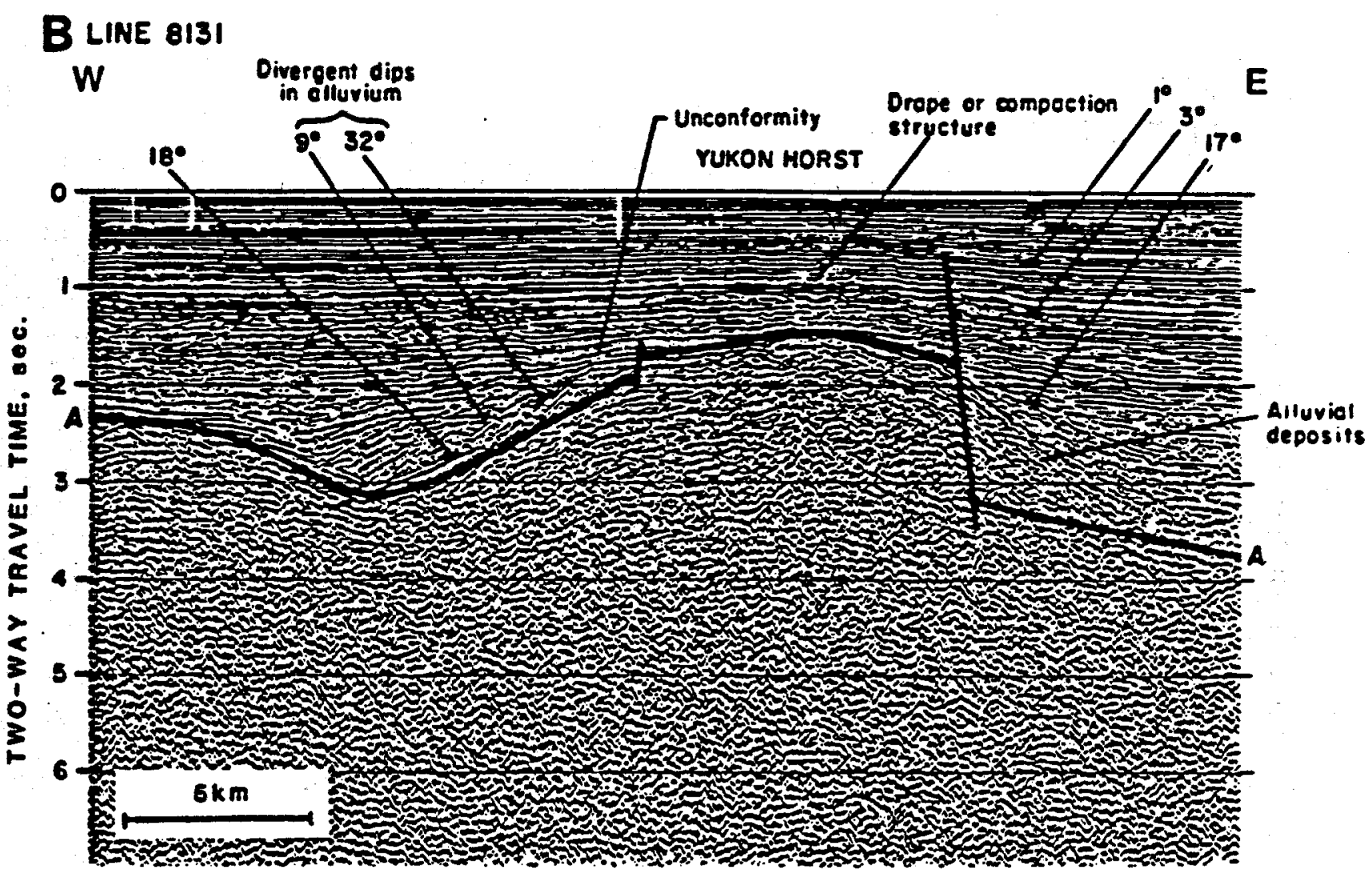

Track-line is shown on Figure 10.

Figure 14. SEISMIC SECTION FROM CENTRAL NORTON BASIN

After Fisher et al., 1982 

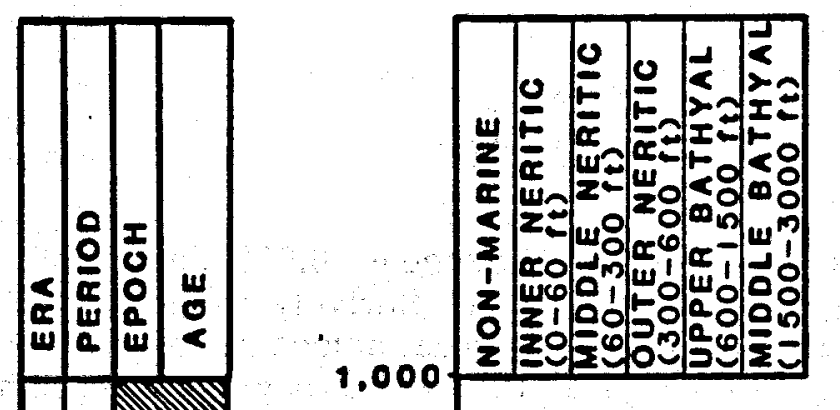

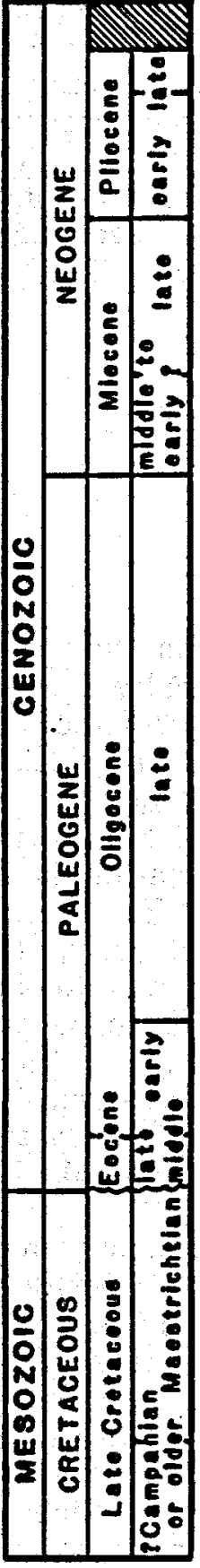
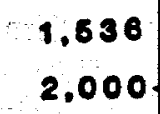
.

3.000

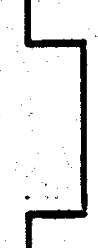

4.000

6,000

ZONE 1

ZONE

2

\begin{tabular}{c}
\hline ZONE \\
5 \\
\hline ZONE 4 \\
\hline
\end{tabular}

ZONE

6

7.000

0,000

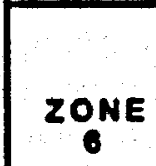

0.000

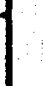

10,000

ZONE

7

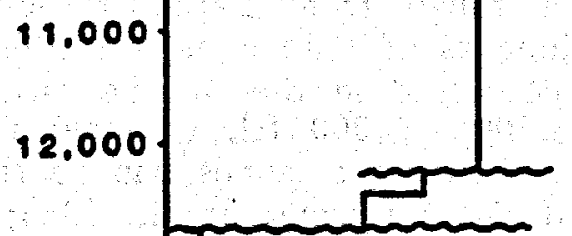

ZONE

8

ZONE 8

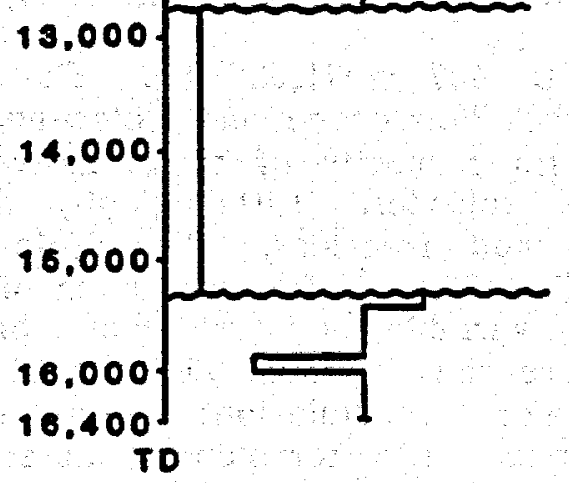

ZONE

10

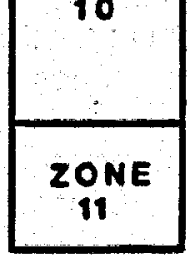

Figure 15. LITHOSTRATIGRAPHIC ZONES AND PALEO BATHYMETRY IN COST WELL NO. 1, NAVARIN BASIN 
15) where the thickness of sediments exceeds $6,000 \mathrm{~m}$. This depocenter, semicircular in its outline, is separated by a relatively shallow saddle (1.5 sec. two-way travel time) from another deep area adjacent to the central section of the Yukon horst (line 813, Figure 12). The depth of basement in this depocenter is approximately 6,000 to $6,500 \mathrm{~m}$. Similar to the Saint Lawrence subbasin, the alluvial fans are present on the flanks of the elevated areas of basement. Acoustically they are probably marking the presence of more faults which otherwise could have been positively identified. The identified faults show the of fset values from some hundred meters to $3,000 \mathrm{~m}$. Gentle folding and strata displacement in lower sedimentary sequences decreases upward and at the acoustic depths less than 1-1.5 sec. The strata do not show structural deformations.

Navarin Basin

\section{Lithostratigraphy}

Prior to 1983, the lithostratigraphic data from the Navarin Basin were based on analysis of dredged rock samples and seismically derived structural data. The Navarin Basin COST Well No. 1, drilled between May 21 and October 22, 1983, provided a detailed insight into the lithostratigraphic development of the basin. The COST Well No. 1 was located in the central part of the Navarin Basin at latitude $60^{\circ} 11^{\prime 24} \cdot 054 \mathrm{~N}$ and longitude $176^{\circ} 15^{\prime} 58.979 \mathrm{~W}$ (Figure 3). Water depth at the well location is approximately $132 \mathrm{~m}(432 \mathrm{ft})$. After numerous technical difficulties the total depth of the well was reached at $5,000 \mathrm{~m}(16,400 \mathrm{ft})$. Stratigraphically, the sediments encountered in the well range from Late Cretaceous to Holocene. In the entire sequence only sediments of Paleocene age seem not to be present. Most of the sediments were deposited in the marine environment within the middle bathyal, 457 - $915 \mathrm{~m}(1,500-3,000 \mathrm{ft})$, to inner neritic zone, $0-21 \mathrm{~m} 10-$ $70 \mathrm{ft}$ ). Eleven lithologically distinct zones can be recognized in the profile of Navarin Basin COST Well No. 1 (Turner et al., 1984; Figure 15).

Zone 1: surface to $407 \mathrm{~m}(1,536 \mathrm{ft})$. The sediments in this interval were deposited during the Pleistocene and Holocene. The Pleistocene strata of the Navarin shelf consists primarily of transgressive and regressive sediments deposited during glacial episodes. Lithologically the latter sediments range from coarse sands to mud fractions. The Holocene sediments appear to constitute a thin layer (i.e. 50 to $7 \mathrm{ft}$ ) over much of the Navarin Basin. These sediments consist of variable mixtures of biogenous and terrigenous components. Diatoms are the dominant element of the biogenous part of the sediment and their major accumulations seems to have occurred in the continental slope and rise. The terrigenous materials with clayey silt as a major component are prevalent in the shelf sediment sequences. Fine sand and sandy silt prevail along the outer shelf and in the heads of the large submarine canyons. 
Zone 2: 407 to $1,177 \mathrm{~m}(1,536$ to $3,860 \mathrm{ft})$. Rocks in this zone are of Miocene and Pleistocene age and are mainly composed of poorly sorted, silty, sandy mudstone, and diatomaceous ooze, deposited in a mid-shelf environment. Grains in this sedimentary sequence are mainly volcanic lithic fragments, angular quartz, and feldspars. The content of diatom and clay matrix ranges from 50 to 80 percent. Volcanic rocks, glauconite, and metamorphic rock fragments constitute a prevalent part of the lithic components of this zone. Effective porosity and permeability in rocks of Zone 10 has been significantly decreased by diagenetic alteration. Diagenetic changes included compaction, dissolution of lithic rocks components, and development of authigenic pyrite, clinoptilolite or heulandite and chlorite. Near the bottom of this zone, the silica minerals of the diatoms seem to be progressively replaced by framboidal pyrite.

Zone 3: 1,177 to $1,527 \mathrm{~m}(3,860$ to $5,010 \mathrm{ft})$. This interval is composed of bioturbated, muddy, very fine-grained sandstone, interbedded with sandy mudstone. The sandstones are poorly to well sorted, bioturbated, and are occasionally cemented with calcite. Below $1,173 \mathrm{~m}(3,850 \mathrm{ft})$ opaline silica derived from diatoms has been diagenetically altered to clinoptilolite or heulandite. Scanning electron microscopy has not confirmed the presence of opal-CT (crystobalite-tridymite). Trace amounts of opal-CT have been identified in trace amounts by X-ray diffraction analysis. Petrographic analysis has shown that the framework grains are composed of quartz, plagioclase, potassium feldspar, and abundant lithic fragments. Those fragments include volcanic, metamorphic, and sedimentary rocks, hornblende, chert, mica, glauconite, and molluscan shell remnants. Authigenic minerals are also present. Their inventory includes pyrite, siderite, smectitic clay, clinoptilolite, analcite, and calcite cement. Although measured porosity of the rocks in Zone 9 appears to be quite high (25 to 35 percent) it is mostly porosity of the intergranular matrix of detrital and authigenic clays. Secondary porosity created by dissolution of grain framework did not change the value of this parameter significantly. Therefore the quality of these rocks as reservoir strata must be considered as low.

Zone 4: 1,527 to $1,615 \mathrm{~m}(5,010$ to $5,300 \mathrm{ft})$. This zone represents rocks of Miocene age, and consists of thin bedded, fine and very fine grained, muddy sandstones, and siltstones interbedded with mudstones and claystones. The sandstones are poorly sorted. The sediments in this zone were probably deposited in a middle to outer neritic environment. Most of the sandstone layers do not exceed thicknesses of $10 \mathrm{ft}$. The lithological composition of rocks in Zone 8 has shown 22 to 30 percent chert and monocrystalline and polycrystalline quartz, 32 to 44 percent lithic fragments, and 31 to 38 percent feldspar.

Zone 5: 1,615 to $2,173 \mathrm{~m}(5,300$ to $7,130 \mathrm{ft})$. The rocks of this zone are of Oligocene and Miocene age, and consist of fine and very fine grained relatively clean to muddy sandstone and siltstone interbedded with mudstone and claystone. The sandstone is poorly to well sorted. The sediments are bioturbated and locally cemented by calcite. Bloturbation occurs in the form of horizontal and oblique burrows. Thin molluscan shells are also present. From well logs it has been found that some of the sandstone strata are up to $100 \mathrm{~m}(328 \mathrm{ft})$ thick. Measured porosity in sandstones proved to be high (28 
to 33 percent) while their permeability was often found to be low due to the presence of detrital clay and to the alteration of framework grains as well as the precipitation of authigenic zeolites. The sediments in this zone were probably deposited in a middle to outer neritic environment.

Zone 6: 2,173 to $2,880 \mathrm{~m}(7,130$ to $9,450 \mathrm{ft})$. This zone is composed of basically the same rocks of Oligocene age as in Zone 5 . Clay composition is different however, as significantly more unaltered smectite is present. Measured porosity of rocks in this zone ranges from 20 to 11 percent whereas permeabilities vary from 0.01 to $1.4 \mathrm{mD}$ and occasionally reach $6-8 \mathrm{mD}$.

Zone $7: 2,880$ to $3,292 \mathrm{~m}(9,450$ to $10,800 \mathrm{ft})$. This zone is composed of sandy mudstone, fine grained muddy sandstone, and claystone with rare lenses of siltstone and sandy carbonate. Isolated coarse-sand size to pebble size volcanic rock fragments have been noted. The sediments composing this interval were probably deposited in marine outer shelf and upper slope environ- ments. A characteristic feature of Zone 5 is the presence of illite which is a product of diagenetic alteration of smectite clays which are predominant in the overlying Zone 6.

Zone 8: 3,292 to $3,743 \mathrm{~m}(10,800$ to $12,280 \mathrm{ft})$. The rocks in this zone are represented by poorly sorted claystone, mudstone, and sandy mudstone with abundance of detrital clay matrix of Oligocene age. The sediments of this section were probably deposited in a bathyal environment. Clays constitute about 40 to 70 percent of the rock and include chlorite, kaolinite, illite, and a mixed layer of illite and smectite. The framework grains are subangular and subrounded and are composed of silt sized monocrystalline quartz, plagioclase and volcanic rock fragments. The rocks of Zone 4 are characterized by very low porosities and permeabilities as a result of small grain size, poor sorting, presence of clay matrix and precipitation of anthigenic minerals.

Zone 9: 3,743 to $8,895 \mathrm{~m}(12,280$ to $12,780 \mathrm{ft})$. This sedimentary sequence of Eocene age is composed of dark gray, calcareous, organic rich claystone. The mineralogy and origin of the rocks in this zone is similar to Zone 2. Porosity and permeability in claystone sediments are very poor because of extremely fine grain size. In the sandy mudstone sequences these two parameters are very low due to poor depositional sorting, fine grain size, and precipitated calcite which filled much of the intergranular space.

Zone 10: 3,895 to 4,660 m $(12,780$ to $15,300 \mathrm{ft})$. The entire section is of Late Cretaceous age and consists of siltstone, very fine-grained sandstone, mudstone, claystone, and coal. This section was probably deposited as a sequence of floodplain, levee, overbank, and paludal sediments. Sedimentary structures display fining-upward sequences, microfaults associated with slumping semiconsolidated sediments, and continuous to discontinuous, wavyand parallel-laminated coal, claystone, mudstone, and sandstone. Framework grains in the sandstone and mudstone consists of quartz, chert, plagioclase feldspar carbonaceous material, volcanic and metamorphic rock fragments. Chert matrix and clay are abundant. The coal occurs in the form of beds up to several feet thick, thin layers within sediments, and as fragments 
disseminated throughout the clastic beds. Effective porosity in the mudstone and siltstone is negligible whereas in sandstone it occasionally becomes moderate. The average porosity in the entire zone is very low. The sedimentary rocks of Zone 2 are intruded by diabase and basalt sills. The top of this zone is marked by an angular unconformity at the approximate depth of $3,895 \mathrm{~m}(12,780 \mathrm{ft})$.

Zone 11: 4,600 to $5,000 \mathrm{~m}(15,088$ to $16,400 \mathrm{ft})$. This sedimentary sequence of Late Cretaceous age is composed of claystone, siltstone tuff, and mudstone. The core from the 4,724 to $4,728 \mathrm{~m}(15,495$ to $15,508 \mathrm{ft})$ interval has been interpreted as a prodelta mud deposit, whereas the sediment from the 4,922 to $4,981 \mathrm{~m}(16,144$ to $16,338 \mathrm{ft})$ interval was deposited in a marine shelf environment. Clay minerals, mainly chlorite, illite, and smectite, amount to as much as 80 percent in rocks of this zone. Zone 1 consists of volcanic rock fragments, quartz, potasium feldspar, pyrite, siderite, calcite, hornblende, and mica. Quartz is the prevalent non-clay mineral. The porosity of rocks is locally reduced by replacement of detrital silt grains and clay matrix with calcite. Weak laminations of small framboids and organic fragments can also be observed in this zone. Thin isolated layers of tuff near the bottom of the zone indicate local volcanic activity.

\section{Rate of Sedimentation}

Although the Navarin Basin represents a young sedimentary basin, significant subsidence and matching deposition took place during the Cenozoic era. The Cenozoic sediments have been deposited in a marine environment where water depths were changing from 180 to $1,100 \mathrm{~m}$ (590 to $3,608 \mathrm{ft}$ ) throughout most of the Paleogene and from 20 to $100 \mathrm{~m}$ (66 to $328 \mathrm{ft}$ ) during the Neogene periods. Based on the lithostratigraphic data from COST Well No. 1 and on seismic data, sedimentation rate during the Tertiary time in the Navarin Basin averaged 100 to $350 \mathrm{~m} / \mathrm{m} . \mathrm{y}$. A thin layer of Holocene sediment (less than $5 \mathrm{~m}$ ) resulted from a diminished rate of sediment deposition combined with erosional activity of currents transporting the sediments toward the continental slope. Higher rates of sediment accumulation on the lower slope $(\sim 150 \mathrm{~m} / \mathrm{m} . \mathrm{y}$.$) are possibly the result of the large amount of downslope$ movement.

\section{Hydrocarbon Occurrence}

One of the indispensible requirements for the gas hydrate formation is the presence of water highly saturated in hydrocarbons. Under those circumstances even small changes in pressure may lead to a release of gas from a solution. At a low enough temperature and an adequate pressure, gas dissolved in water initiate the process of gas hydrate formation. Other conceivable environments in which the gas hydrates may form are transitional water-gas contacts in natural gas deposits. In low porosity formations, these zones with a wide range of gas:water ratio may occur in quite thick intervals. If such zones coincide with sufficiently low temperature and high pressure gas hydrate will be formed. As the gas molecules enter the hydrate structures, 
thus diminishing pore pressure, more gas is released from the solution and delivered to the hydrate zone. In view of the generally described mechanisms of gas hydrate formation, hydrocarbon occurrence in a sedimentary basin is closely related to the potential of gas hydrates.

Initially, natural gas in sediments of the Navarin Basin was recognized on high and intermediate resolution seismic reflection profiles. The gas saturated zones showed similar features to those described from other regions where the presence of gas in sediment was already proved (Cooper et al., 1979; Holmes and Thor, 1982). Subsequently, during cruises in 1980, 1981 and 1982, 141 gravity cores were sampled for extraction and analyses of hydrocarbon gases in Navarin Basin. The samples were collected from the shelf as well as from the lower slope. The deepest extracted gas sample was obtained from a subbottom depth of $580 \mathrm{~cm}$. The results of geochemical analyses of the samples and their interpretation has been presented by Kvenvolden and Redden (1980), and by Carlson et al. (1985). All collected samples were analyzed for the qualitative presence of methane $\left(C_{1}\right)$, ethane $\left(C_{2}\right)$, ethene $\left(C_{2}\right)$, propane $\left(C_{3}\right)$, propene $\left(C_{3}\right)$, isobutane $\left(i-C_{4}\right)$, and $n$-butane $\left(n-C_{4}\right)$. Some results of the gas analyses are shown in Table 1.

\section{TABLE 1.}

\section{CORE SAMPLES FROM NAVARINSKY CANYON WTH $\mathbf{c}_{1}$
CONCENTRATIONS GREATER THAN 1,000 i/n}

\begin{tabular}{|c|c|c|c|c|c|c|c|}
\hline $\begin{array}{l}\text { Core } \\
\text { No.* }\end{array}$ & $\begin{array}{c}\text { Interval } \\
\mathrm{cm}\end{array}$ & $c_{1}$ & $\begin{array}{c}\mu_{1} \\
C_{2}\end{array}$ & $c_{2}$ & $c_{3}$ & $C_{1} / C_{2}+C_{3}$ & $\mathrm{C}_{2} \mathrm{C} / \mathrm{C}_{2=}$ \\
\hline $\begin{array}{l}0-37 \\
1-11 \\
1-13 \\
1-14 \\
1-14 \\
1-15 \\
1-86\end{array}$ & $\begin{array}{l}431-441 \\
190-200 \\
290-300 \\
390-400 \\
552-562 \\
390-400 \\
280-290\end{array}$ & $\begin{array}{r}1,900 \\
84,000 \\
49,000 \\
12,000 \\
44,000 \\
1,400 \\
34,000\end{array}$ & $\begin{array}{l}1.7 \\
0.95 \\
0.45 \\
0.41 \\
0.27 \\
1.3 \\
1.9\end{array}$ & $\begin{array}{l}0.09 \\
0.11 \\
0.15 \\
0.04 \\
0.42 \\
0.02 \\
0.05\end{array}$ & $\begin{array}{l}1.0 \\
3.4 \\
0.7 \\
2.7 \\
1.7 \\
0.24 \\
1.7\end{array}$ & $\begin{array}{r}700 \\
19,000 \\
43,200 \\
3,900 \\
22,000 \\
900 \\
9,400\end{array}$ & $\begin{array}{c}20 \\
9 \\
3 \\
10 \\
0.6 \\
61 \\
35\end{array}$ \\
\hline
\end{tabular}

*0 $=1980,1=1981$.

$1 \mu 1 / 1$ means 1 microliter of gas per liter of wet sediment.

Methane proved to be the prevailing component in gas extracted from the sediment. Its concentrations varied from 1 to $84,000 \mu l$ per liter of wet sediment. The amount of methane in the same samples was usually two to three orders of magnitude larger than the amounts of other hydrocarbon gases. The distribution of methane in the collected samples is shown on Figure 16. It must be emphasized however, that the distribution of the samples with high contents of methane has a patchy character overall as the samples with low contents of methane were also recovered in the same area. Although the concentrations of higher molecular-weight hydrocarbons are insignificant their concentrations facilitate interpretation of the origin of hydrocarbons in the basin. 


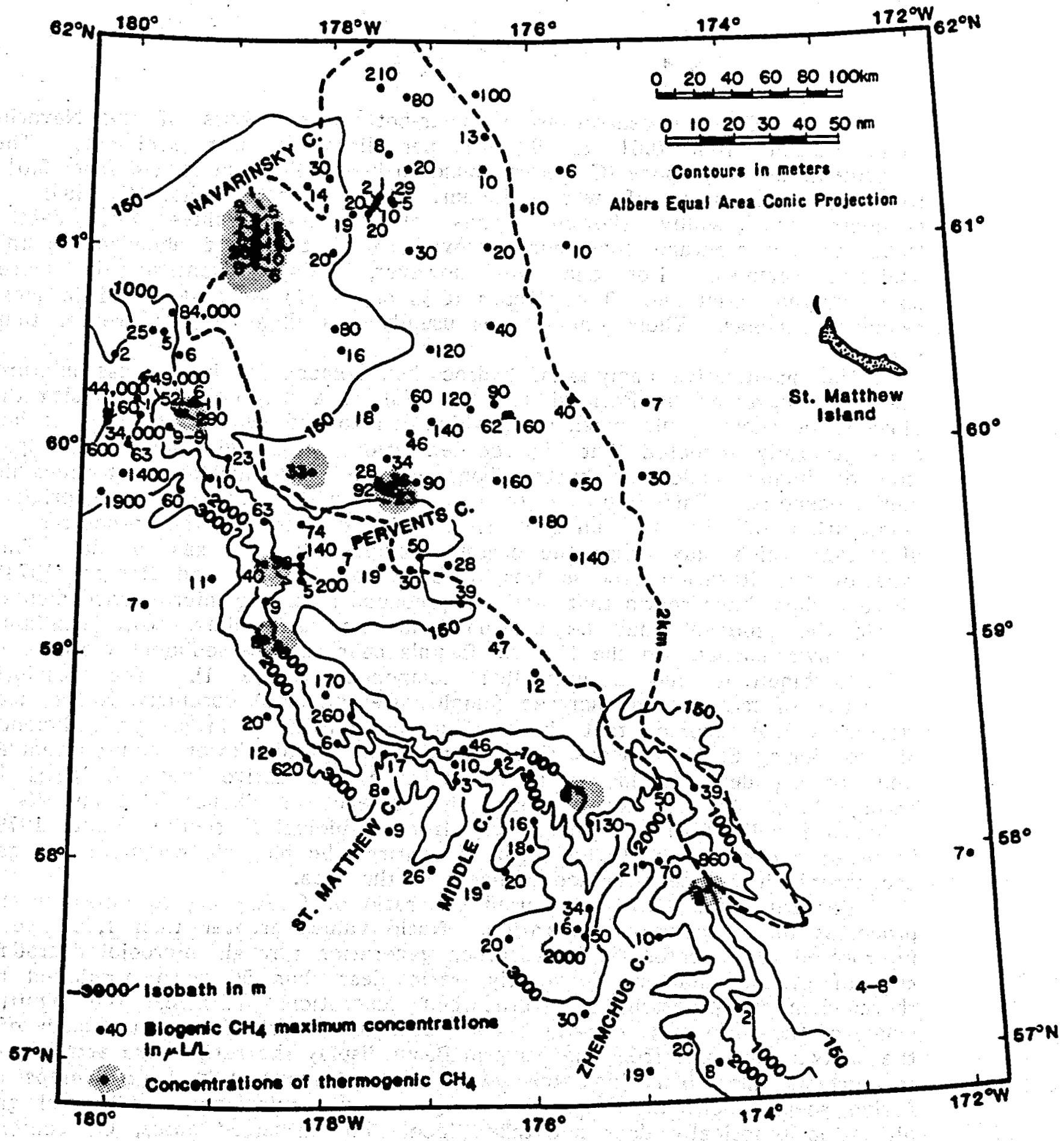

DASHED LINE DELINEATES THE PART OF THE MAVARIN BASIN WHERE BEDIMENT IS THICKER THAN $2000 \mathrm{~m}$.

Figure 16. MAXIMUM CONCENTRATIONS OF METHANE (IN $\mu L / L)$ IN GRAVITY CORES FROM THE NAVARIN CONTINENTAL MARGIN 
Ethane $\left(C_{2}\right)$ concentrations in near-bottom sediments of the Navarin Basin ranged from 0.01 to $9.3 \mu 1$ per liter of wet sediment. The concentrations of propane $\left(C_{3}\right)$ were found to be smaller and ranged from 0.01 to $3.4 \mu$ per liter of wet sediment. It was noted that $C_{1}$ and $C_{2}$ concentrations usually showed trends of increased values with depth. Isobutane and n-butane components proved to be the least abundant in the analyzed samples. Isobutane was however, always quantitatively more abundant than $n$-butane. The alkenes $\left(C_{2}=\right.$ and $\left.C_{3}\right)$ were detected in most sediment samples. Their amount was usually less than $C_{2}$ but greater than $\mathrm{C}_{3}$

The quantitative analysis of hydrocarbon components in the gas mixture has been suggested by Bernard et al. (1978) as a method to distinguish the biogenic or thermogenic mechanism which led to the gas generation. It has been generally accepted that high concentrations of $C_{1}$ with minor participation of higher molecular hydrocarbons is the first indicator of biogenic methanogenesis. This rule has to be applied with caution as the original composition of the gas mixture is usually subject to the processes of alteration which may cause the original composition of a gas to vary. One type of an alteration process was indicated by Martens and Berner (1974). These authors have shown that methane produced in anoxic micro-environments within the sediment may be consumed in the surrounding, more oxidizing macro-environments. In the Navarin Basin's near surface sediment methane is Indeed ubiquitous and a prevailing component (Table 1). The absolute : quantities of methane in analyzed samples are small. Accordingly, Kosiur and Warford (1979) reported that the methane concentrations in margin sediments of the Bering Sea are about five orders of magnitude lower than concentrations of $C_{1}$ detected in anoxic sediments where active methanogenesis is taking place. In the Navarin Basin, the presence of alkenes $\left(C_{2}=\right.$ and $\left.C_{3=}\right)$, which are believed to originate only from a biological source (Hunt, 1979; Primrose and Dilworth, 1976), seem to confirm the biogenic origin of the gas encountered in the near-surface sediment of the area.

Bernard et al. (1978) also used the ratio of $C_{1} / C_{2}+C_{3}$ to interpret the processes of hydrocarbon generation. Ratio values greater than 1,000 were interpreted as indicators of hydrocarbon generation through microbial degradation of organic matter. Conversely, ratios less than 50 were attributed to thermochemical processes in hydrocarbon generation. Although the significance of the ratio of $C_{1} / C_{2}+C_{3}$ has not been sufficiently documented many of the analyzed samples from the Navarin Basin display the ratio value attributed to biogenic gas. This indicator seems to work adequately in the areas of active seeps where the migration of gas occurs relatively rapidly and gas alteration practically does not take place. For dispersed gases, $C_{1}$ content value is frequently changed due to diffusion and microbial consumption. As a result, the ratios of $\mathrm{C}_{1} / \mathrm{C}_{2}+\mathrm{C}_{3}$ measured in near surface sediment tend to exhibit different values from the original ones. This process could probably explain many low values. of the ratio otherwise suggesting the thermogenic origin of the gas. The thermogenically originated hydrocarbons produce gas mixtures in which hydrocarbons heavier than $C_{1}$ compose more than 2 percent. Therefore, low values of the ratio of $C_{1} / C_{2}+C_{3}$ and $C_{2} / C_{2}=>$ may indicate the presence of thermogenic gas. Several gas samples conformed with the criteria for thermogenic gas in the Navarin Basin (Table 2). 
TABLE 2.

CORES WITH POSSIBLE THERMOGENIC HYDROCARBONS*

After Carlson et al., 1985

\begin{tabular}{cccc}
\hline $\begin{array}{c}\text { Core } \\
\text { No. }\end{array}$ & $\begin{array}{c}\text { Interval } \\
\mathbf{c m}\end{array}$ & $\mathrm{C}_{1} /\left(\mathrm{C}_{2}+\mathrm{C}_{3}\right)$ & $\mathrm{C}_{3} / \mathbf{C}_{2}=$ \\
\hline $0-66$ & $\mathbf{5 2 0 - 5 3 0}$ & 20 & 12 \\
$0-109$ & $100-110$ & 50 & 2 \\
$1-12$ & $262-272$ & 28 & 13 \\
$1-20$ & $364-374$ & 50 & 4 \\
$1-37$ & $290-300$ & 42 & 1 \\
$1-57$ & $470-480$ & 44 & 29 \\
$1-58$ & $190-200$ & 11 & 6 \\
$1-60$ & $190-200$ & 25 & 7 \\
$1-66$ & $290-300$ & 24 & 440 \\
$1-77$ & $90-100$ & 41 & 2 \\
$1-88$ & $190-200$ & 23 & 13 \\
$2-7$ & $257-267$ & 19 & 160 \\
$2-8$ & $90-100$ & 8 & 67 \\
$2-9$ & $255-265$ & 12 & 30 \\
$2-11$ & $254-264$ & 16 & 12 \\
$2-12$ & $253-263$ & 17 & 5 \\
$2-13$ & $271-281$ & 30 & \\
\hline
\end{tabular}

*Locations of the cores are shown on Figure 5.

These samples were collected from slope sediments at water depths greater than $150 \mathrm{~m}$. Also some gas samples with thermogenic characteristics were obtained in the northern part of the Navarin Basin (cores 2-7, 8, 9, 11, 12, 13; Table 2). In the same general feature of this area there is a pinching out of the Holocene sediment whereas no other migration pathways of the gas in form of faults or fractures have been found. Based on the presented and auxillary data, Carlson et al. (1985) expressed the contention that hydrocarbon gas in the near-surface sediment of the Navarin Basin is mostly of biogenic origin. Hence, in some limited areas, particularly in marginal parts of the basin, thermogenic gas is present.

\section{Thermogenic Hydrocarbons}

It has been indicated by Carlson et al. (1985) that thermogenic gas is present in sediments of the Navarin Basin. The areal extent of gas samples from near surface sediments showing thermogenic characteristics (Figure 16) seems to coincide in marginal areas of the basin where deep strata from the central part of the basin pinch out or are structurally at shallow depths. Examining these strata with respect to hydrocarbon generation potential seems 
to be a significant element in the interpretation of geochmeical findings in the Navarin Basin. Although 8 exploratory wells have been drilled in the Navarin Basin in 1985 the only publicly available data from formations in the area are from COST Well No. 1.

\section{Organic Carbon}

The content of total organic carbon (TOC) in the vertical profile of COST Well No. 1 is shown. on Figure 17. The analyses of organic carbon of cutting samples have been juxtaposed with the results from sidewall and conventional cores in order to demonstrate reproducibility of the measurements.

It is generally accepted that a minimum 0.5 percent of organic carbon is necessary to generate hydrocarbons (Hunt, 1979). Most of the known hydrocarbon source rocks contain 1 to 2 percent of organic carbon. The amount of organic carbon required to generate hydrocarbons depends additionally upon the type of organic matter as this in turn determines the amount of hydrogen available to react with the carbon.

Geochemical analyses of the organic carbon to a depth of about $600 \mathrm{~m}$ $(1,968 \mathrm{ft})$ are of dubious value as the samples were contaminated with the cement. From about $600 \mathrm{~m}$ to $2,300 \mathrm{~m}(1,968$ to $7,544 \mathrm{ft})$ TOC values are less than 0.5 percent. In the depth interval between 2,300 and $3,600 \mathrm{~m} 17,544$ and $11,808 \mathrm{ft}$ ) TOC values range from 0.5 to 1.0 percent exhibiting little variability. Those samples analyzed in the interval from 600 to $3,600 \mathrm{~m}$ $(1,968$ to $11,808 \mathrm{ft})$ lithologically represented mainly gray-brown siltstone and fine- to medium-grained sandstone.

The interval from 3,600 to $3,900 \mathrm{~m}(11,808$ to $12,792 \mathrm{ft})$ is characterized by a relatively high content of TOC which ranges from 1.0 to 2.0 percent showing little variation. Analytical samples from this interval were collected from intervals of dark-gray mudstone and shale. The analyses of TOC on the conventional core from interval from 3,875 to $3,884 \mathrm{~m}(12,710$ to $12,739 \mathrm{ft}$ ) showed TOC values ranging from 1.31 to 1.89 percent. At a depth between 3,900 and $4,630 \mathrm{~m}(12,792$ and $15,186 \mathrm{ft})$, the results of the organic carbon measurements are extremely variable ranging from as low as 0.06 to 32.67 percent. The samples in this interval were taken from sandstones, siltstones, shales, and coals. The high scatter of data is indicative to a variety of lithologies. Also, high values of TOC are probably caused by vitrinite derived from coal fragments. Below $4,630 \mathrm{~m}(15,200 \mathrm{ft})$ to the final depth of COST Well No. $1,5,000 \mathrm{~m}(16,400 \mathrm{ft})$, TOC analyses of samples from sidewall and conventional cores yielded a relatively low range of values close to 0.5 percent. Lithologically the samples represented mostly hard, gray-brown siltstone, mudstone, and shale with traces to minor amounts of coal.

Considering organic carbon as an indicator of the rocks' potential as a hydrocarbon source, the above presented data seems to suggest that the best source of material occurs at an interval between 3,600 and $4,630 \mathrm{~m}(11,808$ and $15,186 \mathrm{ft})$. It must be stated however that some high values of organic carbon below $3,900 \mathrm{~m}(12,792 \mathrm{ft})$ could have been caused by the presence of coal. 


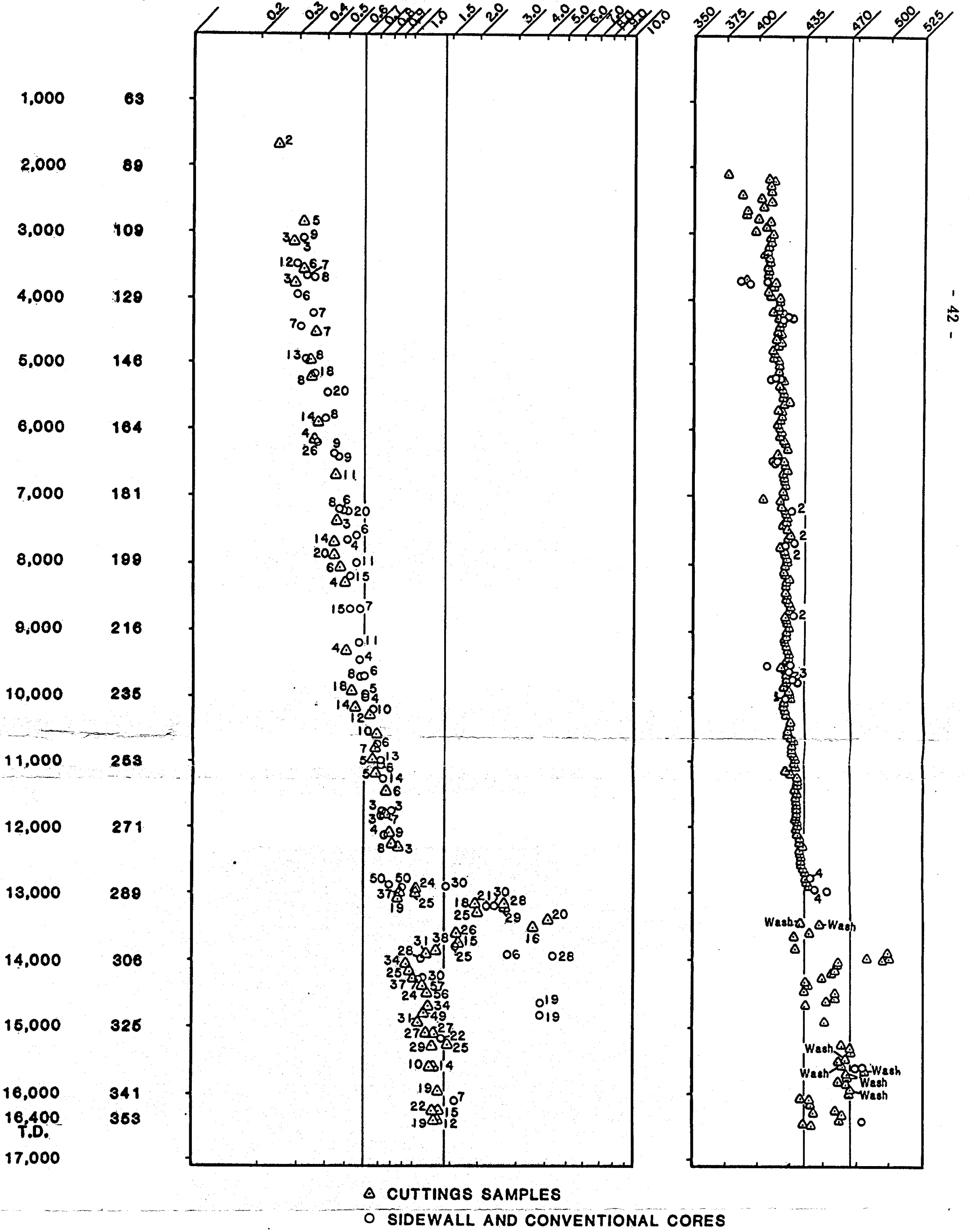

Figure 17. VITRINITE REFLECTANCE AND T2-max FROM PYROLYSIS COST WELL NO. 1, NAVARIN BASIN

After Robertson Research (U.S.) Inc. and Exploration Logging (U.S.A.) Inc., 1984 


\section{Kerogen Synopsis}

The hydrocarbon generation potential of rocks in the Navarin Basin profile of COST Well No. 1 has also been checked on the basis of kerogen examination in reflected and transmitted light, the hydrogen index from pyrolysis, and the hydrogen/carbon (H/C) ratio from elemental analysis. A summary of the results of these analysis is shown on Figure 17. As has been indicated by Dow and O'Connor (1982) the visual estimate of amorphous material and other types of kerogen can be useful in the establishment of gas or oil type of rock source. Based on the large number of geochemical data it has been found that kerogen with less than 35 percent of visual amorphous material and exinite are probably gas prone, whereas 65 percent of these maceral types is needed for oll generation.

The hydrogen indices from pyrolysis with values lower than 100 milligrams of hydrocarbons per gram of organic carbon usually are indicative of immature sediment. Also a H/C ratio from humic kerogens, greater than 0.8 , is interpreted as a sign of the sediment immaturity for hydrocarbon generation (Hunt, 1979).

Three classes of kerogen have been reported from COST Well No. 1. except an amorphous material:

- exinite (hydrocarbons, lipid-rich relics),

- vitrinite (woody and humic components),

- inertinite (hard carbon-rich, brittle particles).

At a depth interval of 510 to $2,130 \mathrm{~m}(1,673$ to $6,986 \mathrm{ft})$ amorphous material with exinite constitutes 20 to 65 percent of the total kerogen. Low hydrogen indices from pyrolysis $(\sim 100 \mathrm{mg} / \mathrm{g})$ and $\mathrm{H} / \mathrm{C}$ ratio reveal immature sediment with respect to hydrocarbon generation. Between 2,130 and $3,870 \mathrm{~m}$ $(6,986$ and 12,694$)$ ft the average values for sapropelic kerogen and hydrogen content are significantly higher and both show a sharp decrease at $3,895 \mathrm{~m}$ $(12,776 \mathrm{ft})$. The hydrogen index and $\mathrm{H} / \mathrm{C}$ ratio are in good general agreement with kerogen content. Most favorable hydrocarbon source rocks occur at a depth of 3,600 to $3,900 \mathrm{~m}(11,808$ to 12,792$)$. The amorphous material and exinite frequently constitute more than 65 percent of the kerogen, while hydrogen indices range in the vicinity of 200 milligrams of hydrocarbons per gram of organic carbon. The H/C analyses showed values ranging from 0.75 to 1.15. Random vitrinite reflectance measurements in sediments of this interval exhibit values of about 0.9. The seismic data from the Navarin Basin confirmed that strata synchronous to this interval in COST Well No. 1 dips in a northwestern direction where it becomes thicker. At depths below $3,900 \mathrm{~m}$ $(12,792 \mathrm{ft})$ in the well, kerogen contains more than 50 percent vitrinite. While the hydrogen indices generally show values less than 100 milligrams of hydrogen per gram of organic carbon, the $H / C$ ratios remain below 0.8 . Presence of coal in significant amount should be considered when interpreting $\mathrm{H}_{2}$ and $\mathrm{H} / \mathrm{C}$ indices.

\section{Thermal Maturation and Hydrocarbon Potential}

Vitrinite reflectance $\left(R_{o}\right)$ is one of the most accepted measures of the degree of thermal maturation reached by carbon-bearing sediment. The validity of this indicator in COST Well No. 1 has been confirmed by its good 
correlation with some other measures of thermal maturity of the sediments. The vitrinite reflectance at a level of 0.6 percent is often considered as the threshold value for oil generation (Hunt, 1979). Such $R_{0}$ values were found in COST Well No. 1 at a depth of about $10,000 \mathrm{ft}$ (Figure 18). When $R_{0}$ attains the value of 1.35 percent, it usually indicates a gas generation zone. In the N.B. COST No. 1 well, such threshold value of $R_{0}$ was found at depth slightly below $4,573 \mathrm{~m}(14,999 \mathrm{ft})$. Anomalously high $R_{0}$ values (up to 4.0 percent) were revealed at the interval between 4,300 and $4,600 \mathrm{~m}(14,104$ and $15,088 \mathrm{ft})$ as well as at depths of 4,443 and $4,500 \mathrm{~m}(14,573$ and $14,760 \mathrm{ft})$. Dow (1977) pointed out that such a $R_{0}$ profile is characteristic for areas with contact metamorphism in sediments adjacent to igneous intrusives.

Several authors (Barker, 1974; Claypool and Reed, 1976; Espitalie et al., 1977) have suggested that the temperature at which maximum changes of hydrocarbons occur ( $T_{\max }$ ) during pyrolysis characterize the degree of thermal maturation of kerogen. Although these measurements can yield varying results due to laboratory procedures (Tissot and Welte, 1978) they provide useful data. The boundaries with $T_{\max }$ temperature $435^{\circ}$ and $470^{\circ} \mathrm{C}$ where the kerogen undergoes crude oil generation were delineated at COST Well No. 1 at a depth of 3,823 to $4,555 \mathrm{~m}(12,539$ to $14,940 \mathrm{ft})$. This depth interval constitutes the oil generation window (Russ, 1983). Based on the pyrolysis data, Martin (1984) concluded that hydrocarbon gas is likely to form at depths greater than $4,600 \mathrm{~m}(15,088 \mathrm{ft})$. Considering the distribution of sediment rich in organic matter, it has been suggested that thermogenic hydrocarbons could have been generated in the interval between 3,050 and $3,900 \mathrm{~m} 110,004$ and $12,792 \mathrm{ft}$ ). The most favorable potential source rocks occur at the base of this interval.

\section{Seismic Expression of Free Gas in Sediment}

Free. gas in sediments of Navarin Basin was first suggested based on seismic anomalies which previously were seen as gas-related in some other areas (Schubel, 1974; Whelan et al., 1975; Cooper et al., 1979; Holmes and Thor, 1982). Three types of such anomalies have been reported from the Navarin Basin:

- reflector pulldowns,

- reflector of fsets,

- reflector terminations.

Reflector pulldown (Figure 20) represents the anomaly caused by the lower compressional velocity of the areas of gas charged zones due to the presence of gas. Holmes and Thor (1982) pointed out that gas does not have to be necessarily in a free state to reduce the velocity of acoustic waves.

Reflector offset type of anomalies are shown on Figure 21. These anomalies are characterized by discontinuity of certain shallow reflectors. The association of such anomalies with gas in sediment has been ascertained in the upper parts of the sedimentary sequences in both the western and eastern Gulf of Alaska (Hampton and Kvenvolden, 1981; Carlson and Molnia, 1977). 


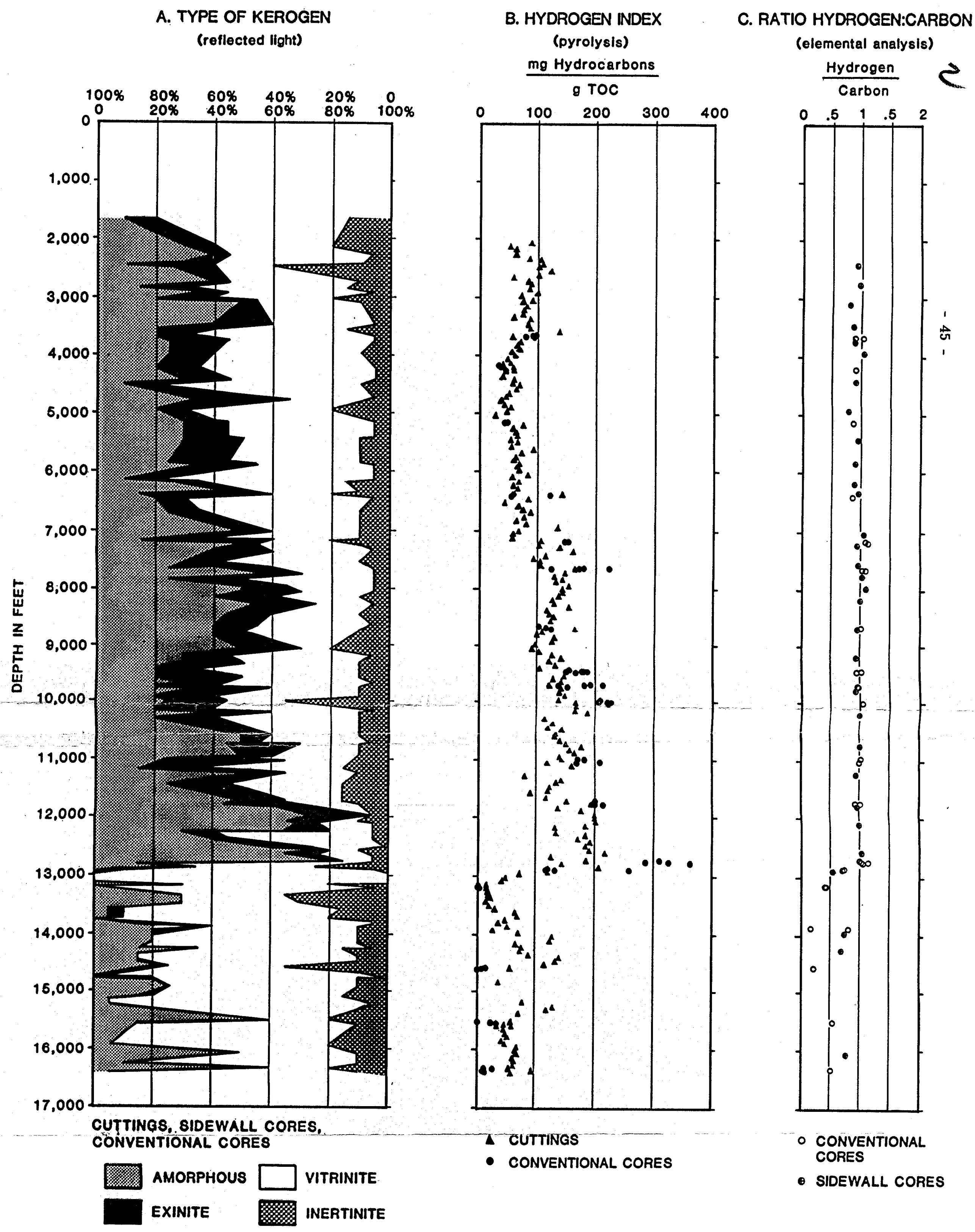

Figure 18. CHARACTERISTICS OF ORGANIC MATTER OF SEDIMENTS IN COST WELL NO. 1, NAVARIN BASIN

After - A., C. - Robertson Research (US) Inc., 1984

- B. - Exploration Logging (USA) Inc., 1984 


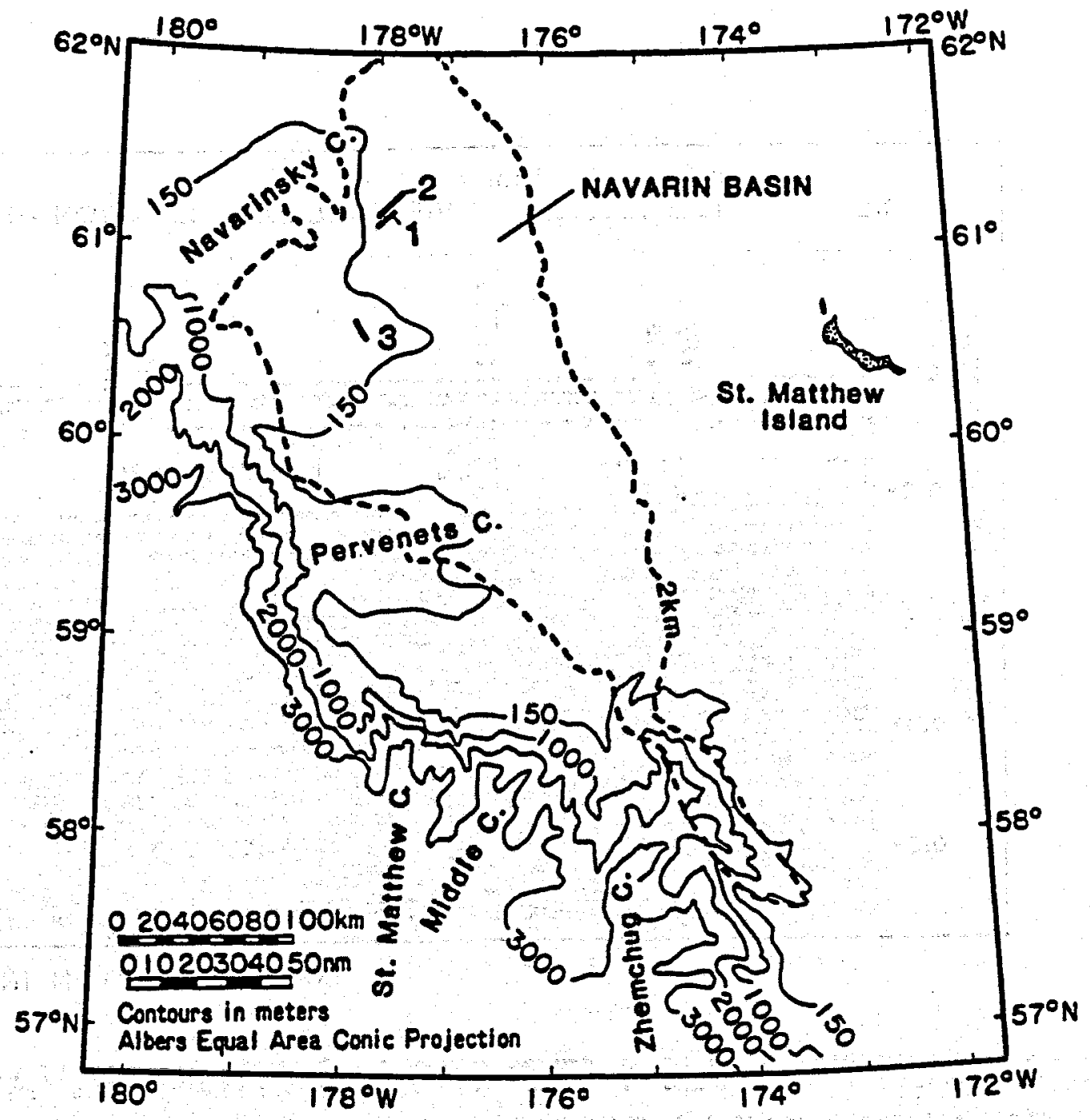

igure 19. LOCATIONS OF SEISMIC LINES SHOWN IN FIGURES $20,21,22$ 


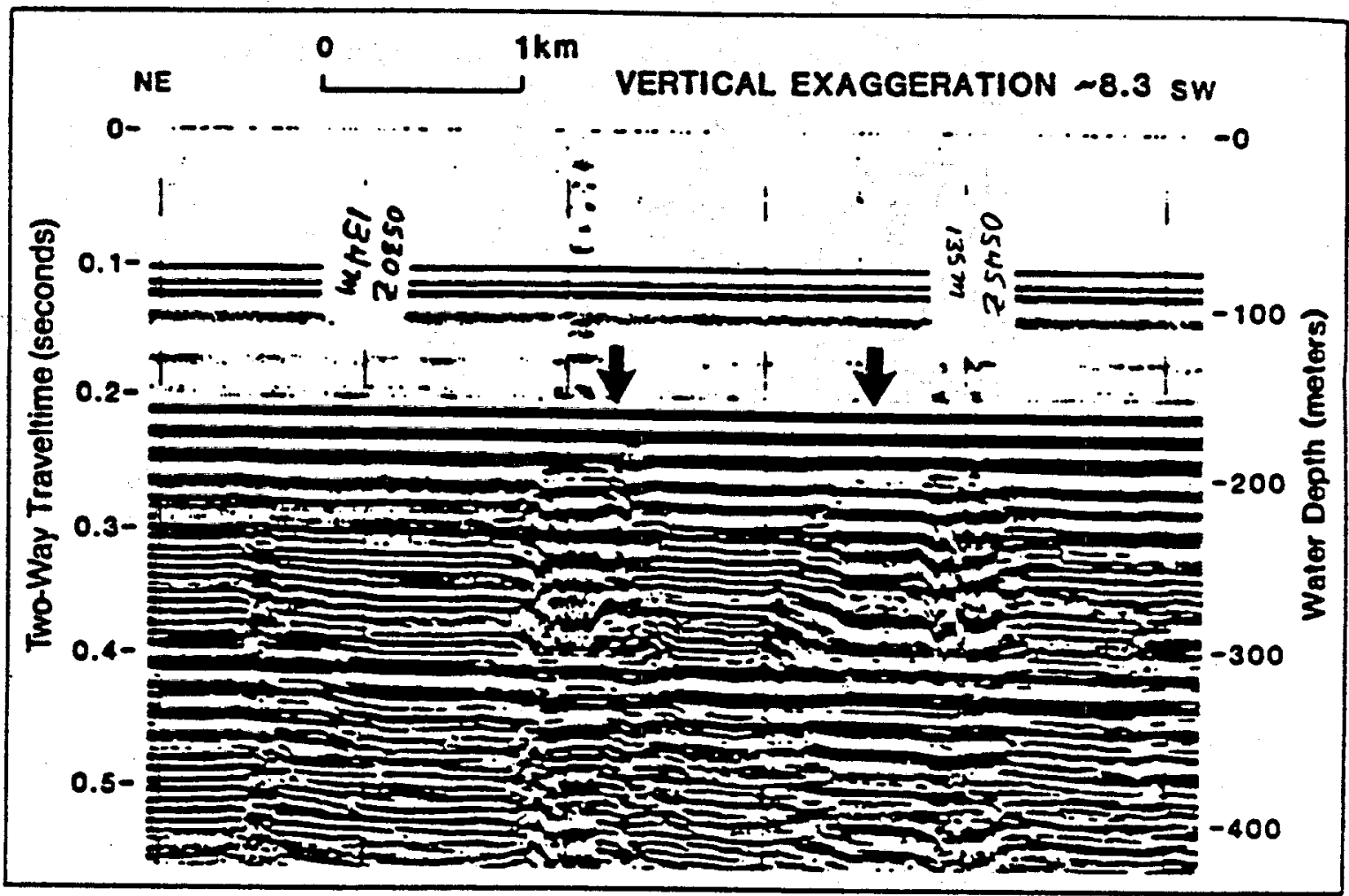

LOCATION SHOWN IN FIGURE 19.

Figure 20. AIRGUN PROFILE $1(75-200 \mathrm{~Hz})$ FROM NAVARIN BASIN SHOWING PULLDOWNS (ARROWS) ASSOCIATED WITH GAS-CHARGED SEDIMENT

After Carlson et al., 1985 


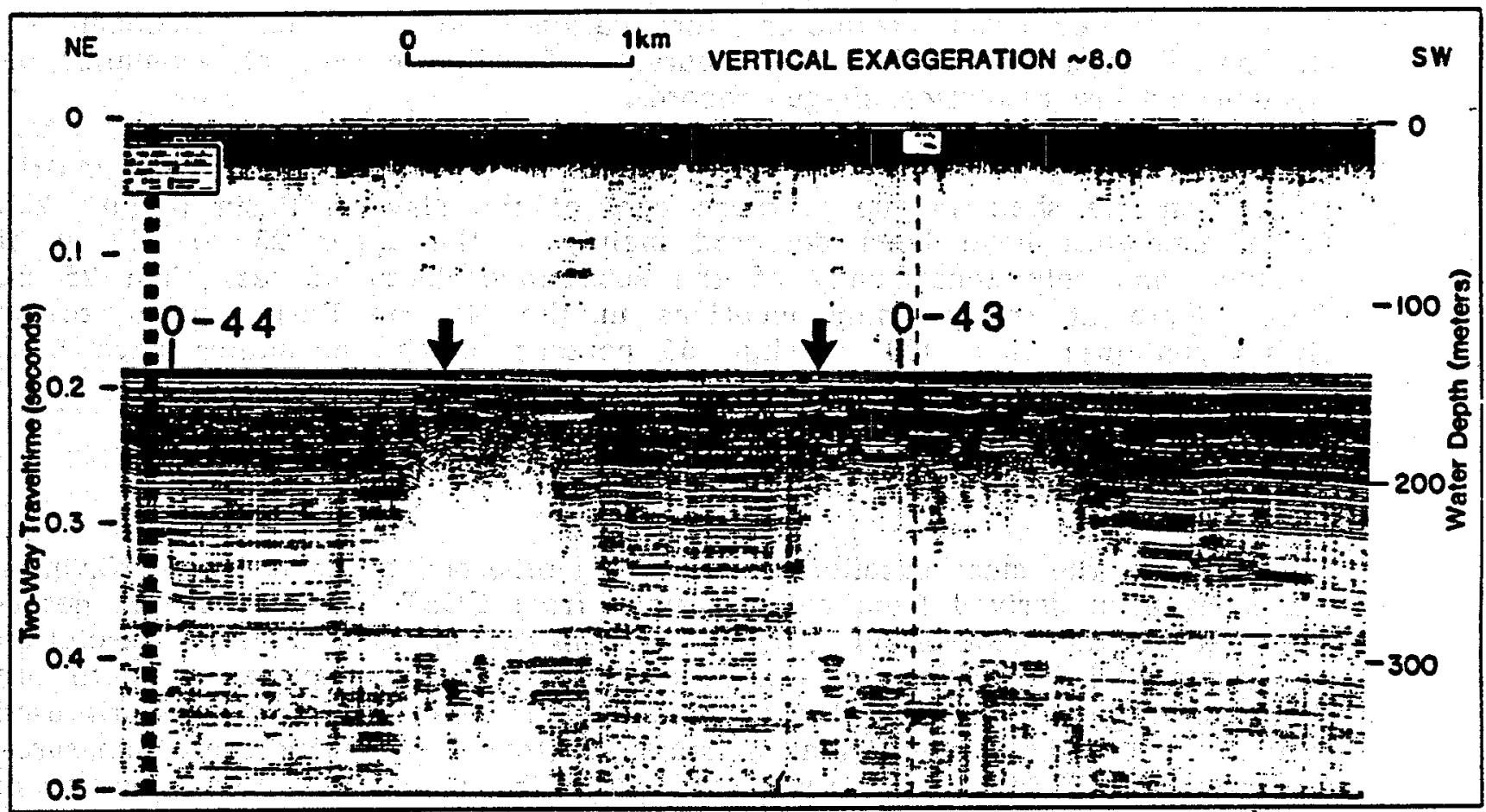

LOCATION SHOWN IN FIGURE 19.

igure 21. MINISPARKER PROFILE $2(150-1,100 \mathrm{~Hz})$ FROM THE NORTHERN PART OF NAVARIN BASIN AND SHOWING REFLECTOR TERMINATIONS AND PULLDOWNS (ARROWS) ATTRIBUTED TO GAS CHARGED SEDIMENT 
Reflector termination anomalies presented on Figure 22 occur in a form of abrupt termination of the acoustic reflectors. These anomalies are particularly noticeable on high resolution seismic records obtained with Uniboom and minisparker techniques. Some authors (Holmes and Thor, 1982; Carlson et al., 1985) contended that reflector termination anomalies on Uniboom or minisparker seismic records exhibit features of pulldown type of anomalies on medium and low resolution air-gun records.

All three of the above briefly described seismic anomalies are mostly present on the shelf in the northern part of the Navarin Basin (Figure 23). These anomalies have been detected mainly in the upper 25 to $100 \mathrm{~m}$ of sediment and only occasionally at the subsurface depth of less than $25 \mathrm{~m}$. Water depth at the anomaly locations in the Navarin Basin appear to be always shallower than $400 \mathrm{~m}$ while 55 percent of the anomalies have been found in areas with water depth less than $150 \mathrm{~m}$ (Carlson et al., 1985).

\section{Geothermal Gradient}

Perhaps the most detailed analysis of geothermal gradient in the Navarin Basin has been derived from data obtained from COST Well No. 1. In determination of the geothermal gradient, Martin (1984) used a High Resolution Thermometer log (HRT). The values of these data in function of depth are shown in Figure 24. Considering all the shortcomings of various data used (Martin, 1984) the combination of static bottom hole temperature measurements and DST (drill stem test) data seems to provide the best picture of geothermal gradient in the profile of COST Well Nó. 1. Linear regression (least squares applied to BHT and DST data) yielded a thermal gradient of $1.78^{\circ} \mathrm{F}$ per $100 \mathrm{ft}\left(2.95^{\circ} \mathrm{C} / 100 \mathrm{~m}\right)$ in the interval from 1,160 to $5,000 \mathrm{~m}(3,800$ $\mathrm{ft}$ to $16,400 \mathrm{ft})$. Above $1,160 \mathrm{~m}(3,800 \mathrm{ft})$ the gradient is significantly higher and was estimated to be $2.5^{\circ} \mathrm{F}$ per $100 \mathrm{ft}\left(4.46^{\circ} \mathrm{C} / 100 \mathrm{~m}\right)$. The higher geothermal gradient can be explained by a change in lithology and degree of compaction of sediments above $1,160 \mathrm{~m}(3,800 \mathrm{ft})$. The unconsolidated, undercompacted, diatomaceous sediments have lower average thermal conductivity than more compacted rocks below $1,160 \mathrm{~m}(3,800 \mathrm{ft})$.

\section{Norton Basin}

\section{Lithostratigraphy}

Although 5 wells have been drilled in Norton Basin area the most detailed publicly available lithostratigraphic data is from the ARCO Norton Sound COST No. 1 well. The well was located in the central part of St. Lawrence subbasin at latitude $63^{\circ} 46^{\prime} 48.97^{\prime \prime} \mathrm{N}$ and longitude $166^{\circ} 05^{\prime} 10.40^{\prime \prime} \mathrm{W}$. Some additional information on the lithostratigraphy of Norton Sound was derived from St. Lawrence Island and from the onshore areas of the Seward Peninsula and the Yukon-Koyukuk Province where older formations of the Norton Basin crop out. 


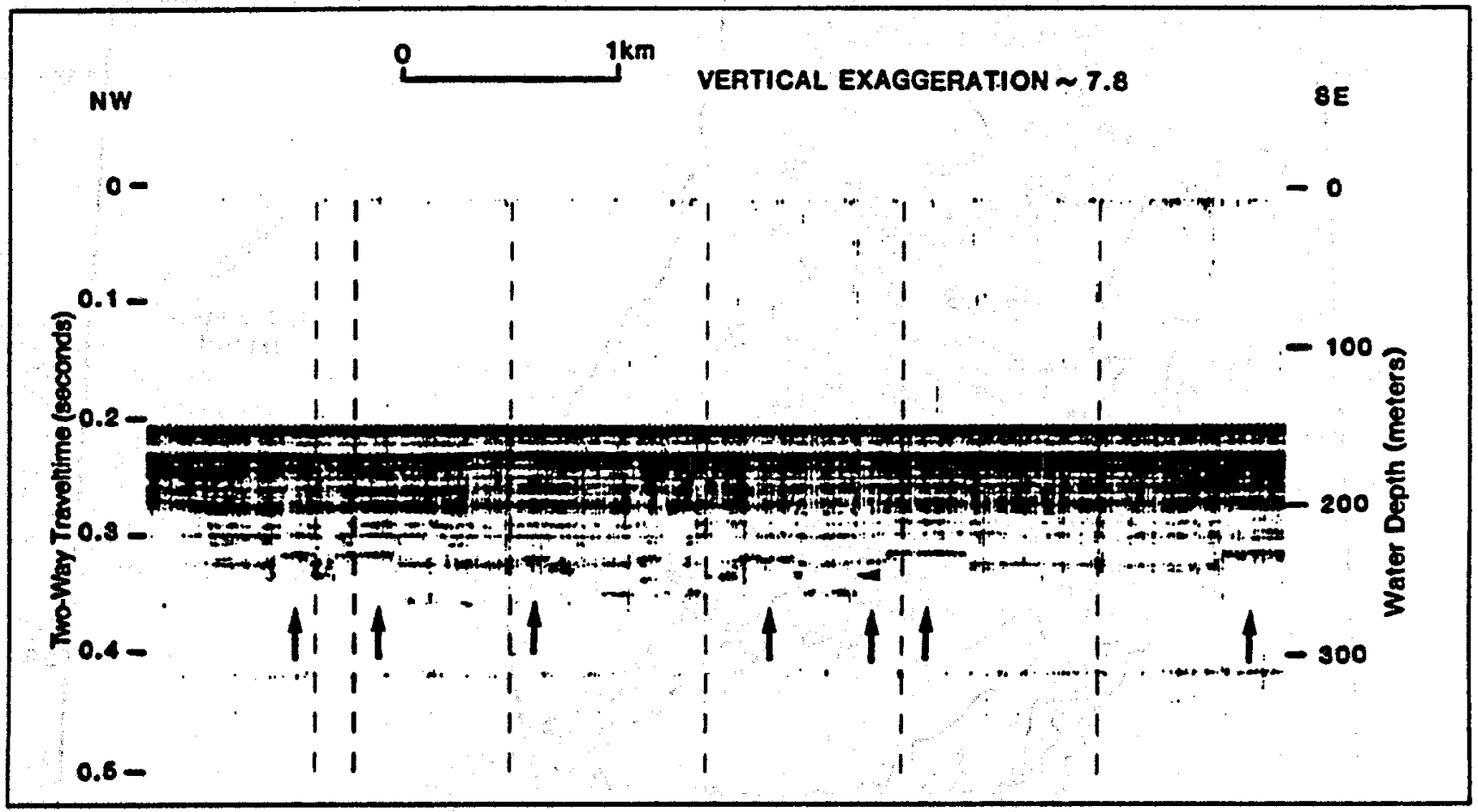

LOCATION SHOWN IN FIGURE 19.

Figure 22. UNIBOOM PROFILE $(400-2,500 \mathrm{~Hz})$ FROM NAVARIN BASIN SHOWING REFLECTOR OFFSETS (ARROWS) ATTRIBUTED TO GAS-CHARGED SEDIMENT 


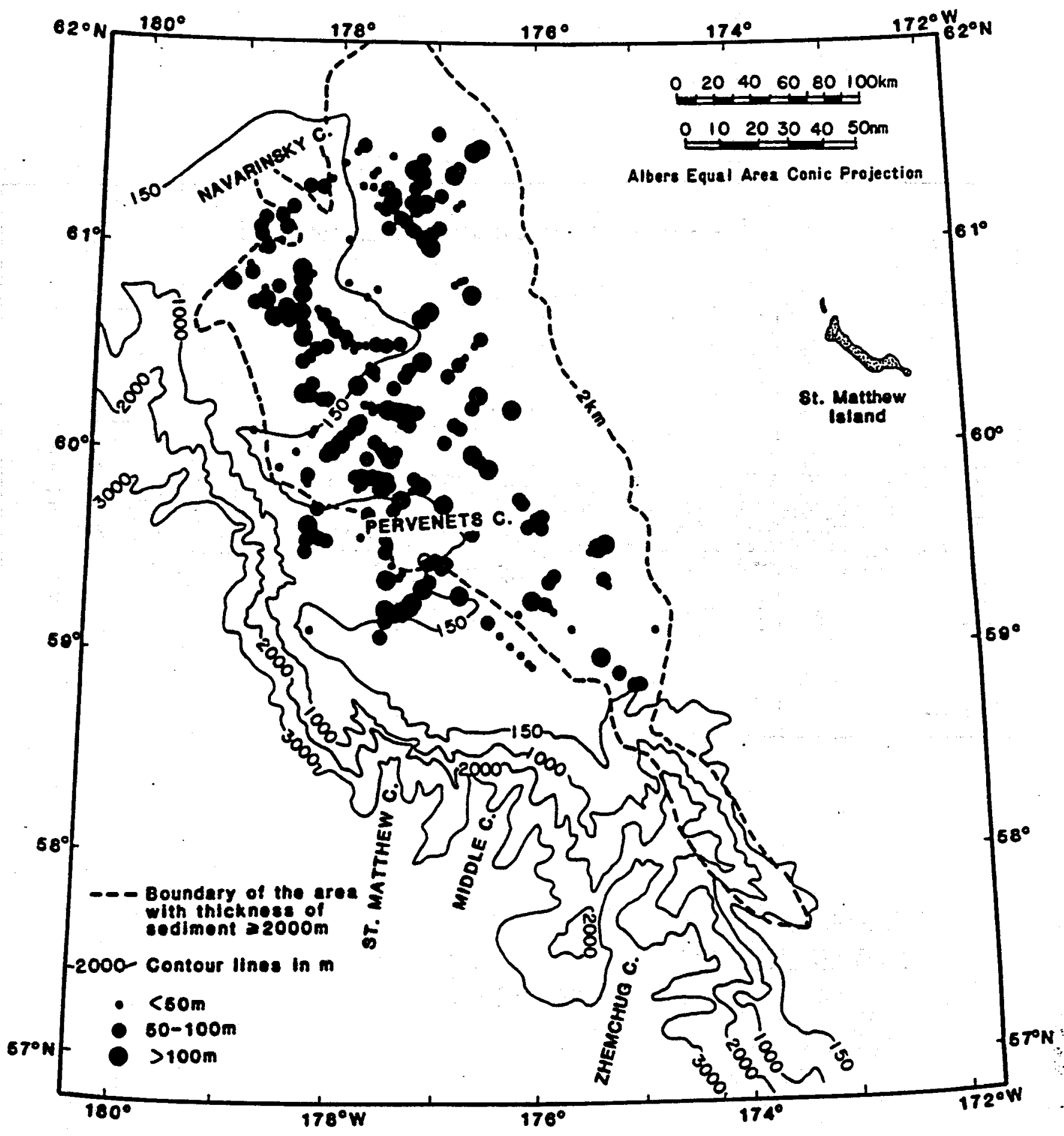

DASHED LINE DELINEATES $\geq 2 \mathrm{~km}(6,60011)$ THICKNESS OF NAVARIN BASIN SEDIMENT

Figure 23. DISTRIBUTION OF SEISMIC ANOMALIES IN NAVARIN BASIN ATTRIBUTED TO GAS-CHARGED SEDIMENT 
Temperature $\left({ }^{\circ} \mathrm{F}\right)$

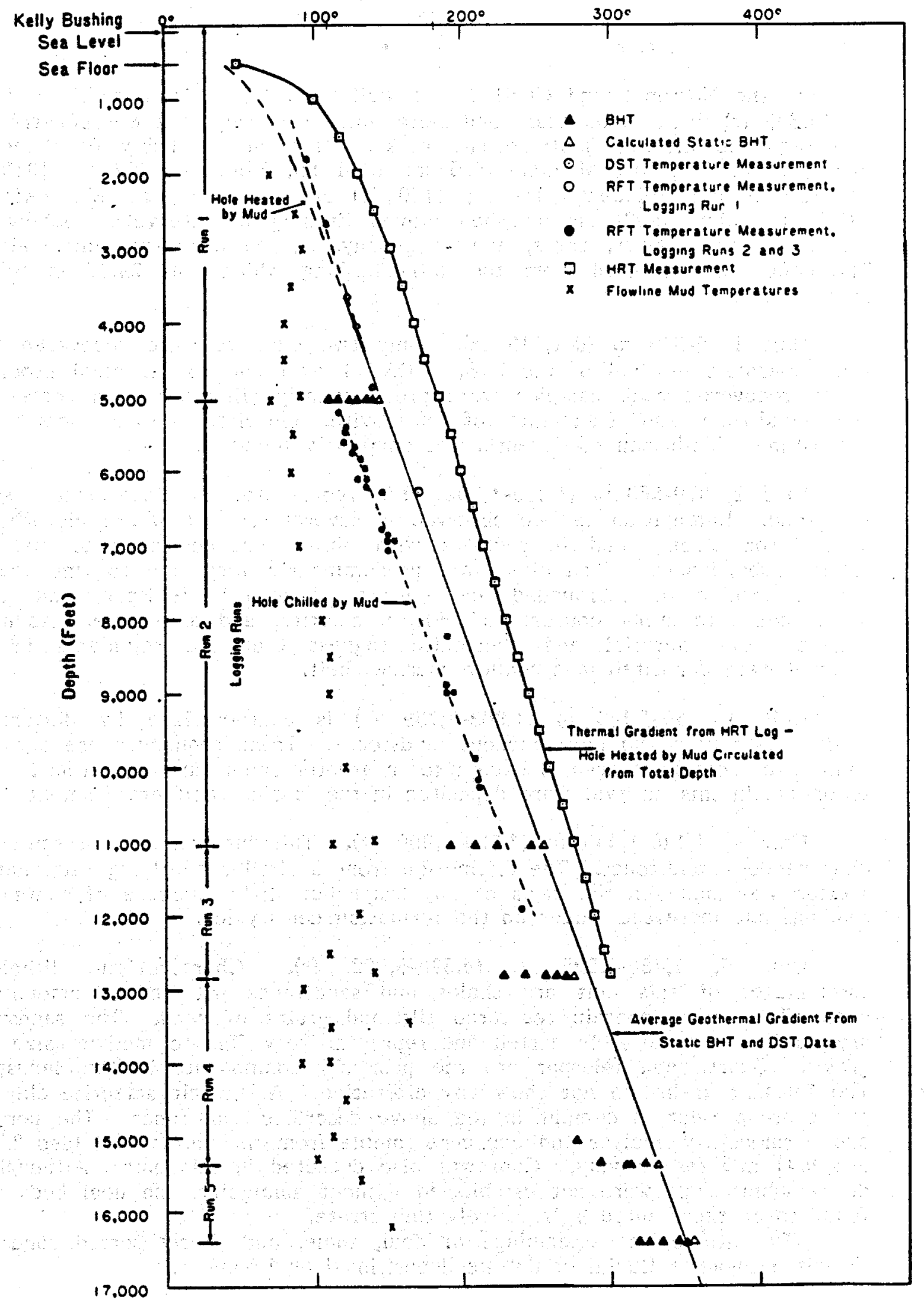

Figure 24. THERMAL GRADIENT FOR THE NAVARIN BASIN COST NO. 1 WELL 
At the Norton Sound COST No. 1 well (N.S. COST 1), a total of 4476.5 m $(14,683 \mathrm{ft})$ thick sedimentary and metasedimentary sequence was penetrated. The sequence includes metamorphic rocks. They are probably of Paleozoic age (652 m; $2138 \mathrm{ft}$ ), Miocene (565 m; $1854 \mathrm{ft}$ ), Pliocene (402 $\mathrm{m} ; 1319 \mathrm{ft}$ ), Pleistocene and Holocene $(347 \mathrm{~m} ; 1140 \mathrm{ft})$ age rocks (Figure 25). At N.S. COST 1, Bolm (1983) distinguished eleven lithological intervals. Subdivision was based on cuttings, -cores, and on geophysical log interpretation (Plate 1). The depths are counted from the kelly bushing which was $29.87 \mathrm{~m}$ (98 ft) above sea level:

Unit 1, 0-370 $\mathrm{m}(0-1,213 \mathrm{ft})$. Only two cuttings were recovered from this uppermost interval of the N.B. COST 1 well due to technical problems. - Those recovered rock samples were predominantly siltstones with some very fine sandstone and fragments of muscovite, chlorite, biotite, schist and greenstone. Molluscan shell debris was commonly found.

Unit 2, 370-580 $\mathrm{m}(1,213-1,902 \mathrm{ft})$ is represented by diatomaceous sandy sandstone. Lamination can be observed in several sections where bioturbation is not too strong, and in sections with abrupt changes of sand and mud relative abundances. Sand clasts are predominantly very fine to fine grained and subangular to subrounded and consist of quartz, feldspar, and green hornblende with minor contents of biotite, chlorite, and muscovite. Abundant marine fossil material and glauconite suggest that the sediments in this interval were deposited in a shallow marine shelf.

Unit . 3, 580-1,140 $\mathrm{m}(1,902-3,739 \mathrm{ft})$ is characterized by diatomites; muddy diatomites and diatomaceous mudstones. These sequences are basically similar to those in interval 4 except for a greater abundance of diatoms. The sediments in this interval were deposited in the marine shelf environment.

Unit 4, 1,140-1,430 $\mathrm{m}(3,739-4,690 \mathrm{ft})$. This interval is represented by diatomaceous mudstones. The distinction from a similar overlying sedimentary section was made on the basis of an abrupt but slight increase of gamma-ray readings and increased values on the formation density log.

Unit 5, 1,430-1,525 m (4,690-5,002 ft). Characteristic lithologic assemblages of this unit are shales and sandstones with minor amounts of coal. The shales contain scattered silt and grains of sand. The sandstones are poorly to moderately sorted and represent very fine to medium size sand grains. Quartz and feldspar are the principal components in the sandstone. The feldspar grains do not show any alteration. Authigenic smectite clay and pyrite are present as cement in the above described sandstones. The porosity and permeability analyses on one core sample from this interval yielded $28.7 \%$ and $9.41 \mathrm{mD}$ respectively. Coal was also detected in this unit. Although its depth subintervals were not established without ambiguity, the coal beds were found to be represented by relatively thin strata.

The lithological assemblage of coal, shale, and poorly sorted sandstone in unit 5 suggests fluvial or deltaic depositional environment.

Unit 6, 1,525-2,953 m (5,002 - 9,685 ft). Mudstones and shales with some interbedded sandstones are the major lithotypes in this interval. Shales 
$-54-$

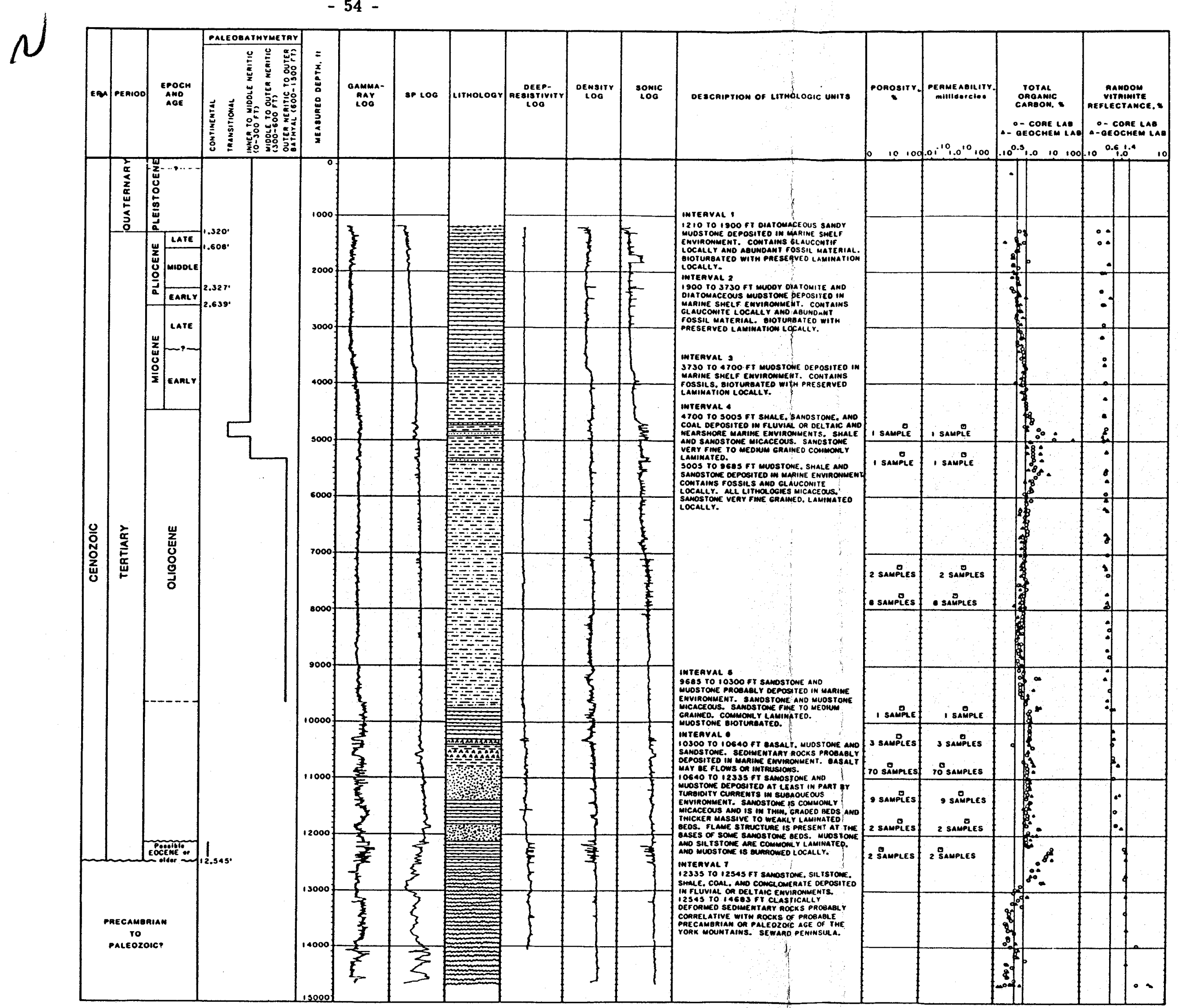

Figure 25 STRATIGRAPHIC COLUMN AND SUMMARY CHART OF GEOLOGIC DATA, NORTON SOUND COST NO. 1 WELL, NORTON SOUND, ALASKA 
are olive-gray and slightly silty. Glauconite was reported from one sample from the depth of $2,878 \mathrm{~m}(9,440 \mathrm{ft})$. Mudstones are olive- black and sandy. Medium-dark-gray sandstone is very fine grained, calcareous and weakly laminated. Locally it is extensively burrowed. The sandstone in this interval commonly contains minor amounts of glauconite. Porosity in sandstone formations was found to be 16.7 to $23.6 \%$ whereas the highest permeability was $0.36 \mathrm{mD}$. The presence of glauconite and fossil fragments in described sediments indicate a shallow neritic depositional environment.

Unit 7, 2,953-3,140 m $(9,685-10,300 \mathrm{ft})$. The sediments of this unit consist of interbedded sandstone and mudstone. Contrary to the previous interval volcanic rocks are scarce in this sedimentary section.

Unit $8,3,140-3,245 \mathrm{~m}(10,300-10,643 \mathrm{ft})$ is represented by interbedded sandstone, mudstone, and igneous rock. The sandstone in this interval is fine to medium grained and moderately to well sorted. Generally, subrounded grains of these sandstones consist of such components as quartz, muscovite, plagioclase, and metamorphic rock fragments. Quartz constitutes about 50 to $65 \%$ of the sandstone framework while the muscovite accounts for 10 to $20 \%$ and is commonly unaltered and of albitic composition. Metamorphic rock fragments which comprise about $10 \%$ of the clasts are represented mostly by phyllite and fine grained mica schist and quartz mica schist. The authigenic quartz overgrowth and ductile grain deformation effectively reduced intergranular porosity of the sandstones. Black mudstone was found to be massive or laminated where the lamination is defined by muscovite flakes or interlaminated with sandstone. The igneous lithology in this depth interval is mainly basalt. Most of the basaltic fragments exhibit an intersorted texture In which the interstices between the plagioclase laths are filled with calcite, clay, and magnetite. Trachyte is another igneous lithology found in this unit. It is texturally similar to basalt with the exception of plagioclase which is replaced by feldspar. The third type of igneous rock encountered in this interval was vitrophyre.

Unit $9,3,245-3,730 \mathrm{~m} \cdot(10,643-12,235 \mathrm{ft})$ consists of sandstones and mudstones. The sandstones are predominantly in thin graded beds. Shale clasts as well as coal fragments, stringers and lenses are scattered throughout thicker sandstone beds. Black mudstones are laminated with scattered very fine sandstones and are locally burrowed. The porosity in this interval ranges from 2.9 to $11.9 \%$ whereas the permeability analyses showed values within 0.02-0.38 mD. The sedimentary structures in the sandstone strata including preserved burrows in at least some sandstone layers indicate a subaqueous depositional environment.

Unit $10,3,730-3,825 \mathrm{~m}(12,235-12,546 \mathrm{ft})$. This unit is characterized by interbedded sandstone, siltstone, shale, coal and conglomerate. Coarse and poorly sorted sandstone consists mostly of phyllite and fine grained quartz muscovite schist fragments. Clasts of detrital sparry dolomite, polycrystalline quartz, and chert are also present in the sandstone framework. The porosity in this depth interval ranging from 1.0 to $2.6 \%$ was diminished mainly by ductile grain deformation and by filling of the intergranular space by kaolinite. Permeability measured on five samples was very low and ranged 
from 0.02 to $0.12 \mathrm{mD}$. Siltstones and conglomerate sequences are mineralogically similar with sandstone. The shale is micaceous and carbonaceous. Abundance of coal was found in cuttings from the entire unit.

Unit 11, 3,825-4,476.5 $\mathrm{m}(12,546-14,683 \mathrm{ft})$ is represented by metasedimentary rocks including mylonite and cataclastite. Within the matrix coarse sand-to-pebble size fragments of sandstones, siltstones, schist, phyllite, quartz, and chert were found. Also some cataclastic marble and finely crystalline carbonate were noticed.

\section{Organic Carbon}

The proper assessment of the potential of a rock for hydrocarbon generation must involve several characteristics among which total organic carbon (TOC) content is of prime importance. Although some laboratories use $1 \%$ of total organic carbon as a lower limit for detrital hydrocarbon source rock, the value $0.5 \%$ is widely accepted (Ronov, 1958; Hunt, 1979; Tissot and Welte, 1984). The N.B. COST 1 well rock samples from cuttings, sidewall cores, and conventional cores were analyzed for TOC content (Figure 26). There is a slight possibility that some high TOC values could have been caused by contamination with coal. At the interval 4,476.5-3,965 $\mathrm{m}(14,683-$ $13,005 \mathrm{ft}$ ) the organic carbon values range between 0.2 and $0.5 \%$ with the exception of the two samples where $1.0 \%$ TOC was found. The sedimentary section between $3,965-2,895 \mathrm{~m}(13,005-9,496 \mathrm{ft})$ exhibits relatively high TOC values ranging from 1 to $2 \%$. Yet some higher values were found from cuttings containing coal. From depths 2,895-1,800 m $(9,496-5,904 \mathrm{ft})$ TOC values show gradual increase from 0.8 to $1.0 \%$. Some higher TOC values $(3-4 \%)$ at $2,805 \mathrm{~m}(9,200 \mathrm{ft})$ are probably caused by traces of coal. The interval $1,800-1,370 \mathrm{~m}(5,904-4,493 \mathrm{ft})$ is characterized by elevated values of TOC (2-5.2\%). These anomalies coincide with lithologies containing up to $15 \%$ of coal. From the depth of approximately $1,370 \mathrm{~m}(4,493 \mathrm{ft})$ upward, TOC values decrease steady from 1.1 to $1.2 \%$ to slightly less than $0.5 \%$.

\section{Kerogen Characteristics}

The results of microscopic investigation as well as elemental analyses and pyrolysis of the kerogen in rock samples from N.B. COST 1 well and from some onshore locations are shown in Figures 27, 28, 29, and 30 and Table 3. In the top $3,180 \mathrm{~m}(10,430 \mathrm{ft})$ interval in the N.B. COST 1 well, kerogen is composed predominantly of herbaceous and woody material which corresponds to vitrinitic and exinitic types of kerogen (Figure 27). The content of alginite which is marginal at depths $300-1,370 \mathrm{~m}$ (984-4,494 ft) varies significantly below a depth of $1,370 \mathrm{~m}(4,494 \mathrm{ft})$ where inertinite becomes a main type of kerogen. Microscopic observations of kerogen appear to be in general agreement with average hydrogen/carbon $(\mathrm{H} / \mathrm{C})$ ratios described by Hunt (1979), i.e. approximately $1.2 \%$ for herbaceous kerogen, $0.72 \%$ for woody. At a depth of $3,785 \mathrm{~m}(12,415 \mathrm{ft})$, where the kerogen is composed of $80 \%$ inertinite, the $\mathrm{H} / \mathrm{C}$ values are 0.61 . The low $\mathrm{H} / \mathrm{C}$ values observed in the entire profile of the N.B. COST 1 well qualify the rocks as a rather poor source for hydrocarbon generation. 


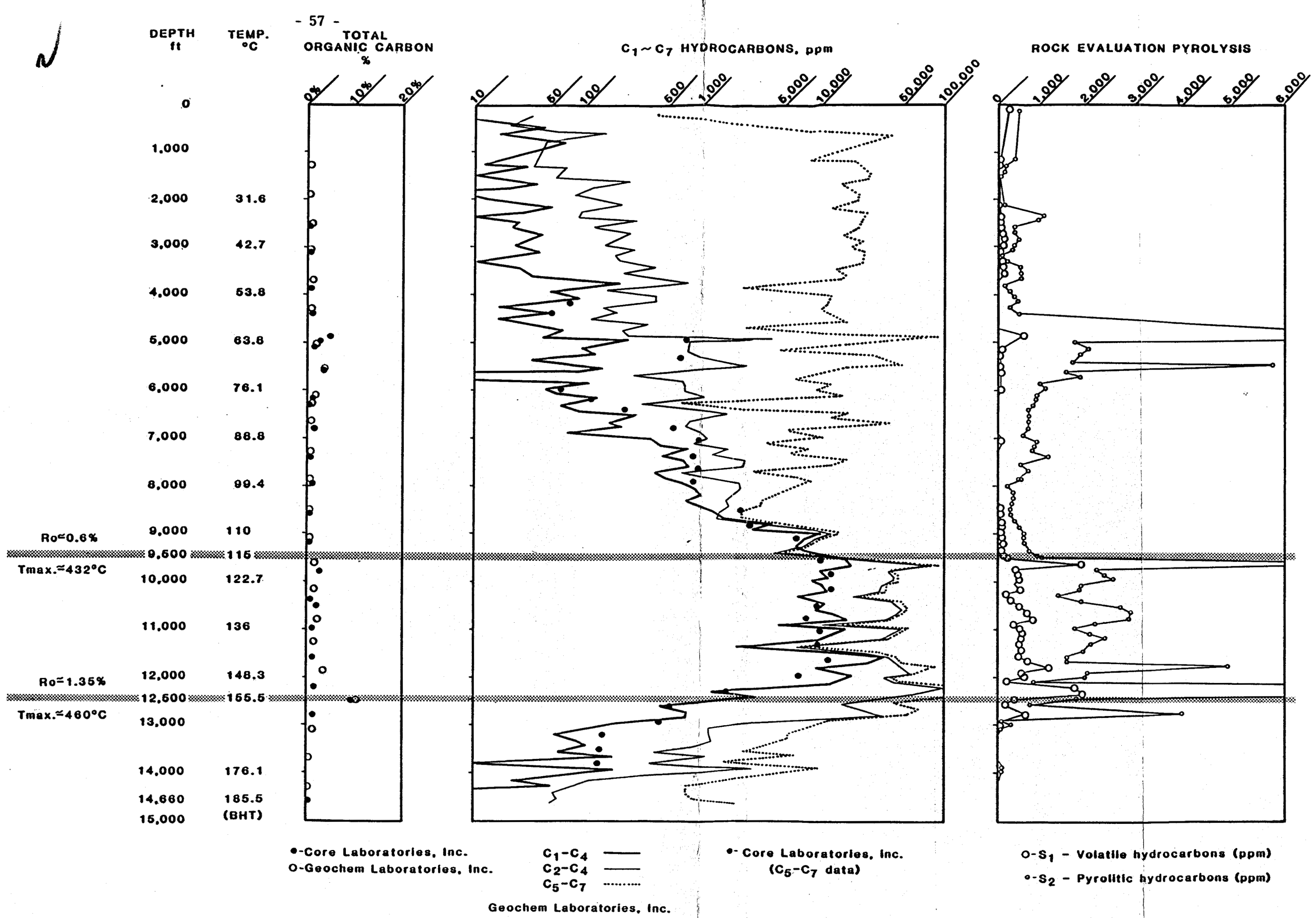

Figure 26. RESULTS OF GEOCHEMICAL ANALYSIS OF ROCK SAMPLES FROM NORTON BASIN COST WELL NO. 1

After Flett, 1983 


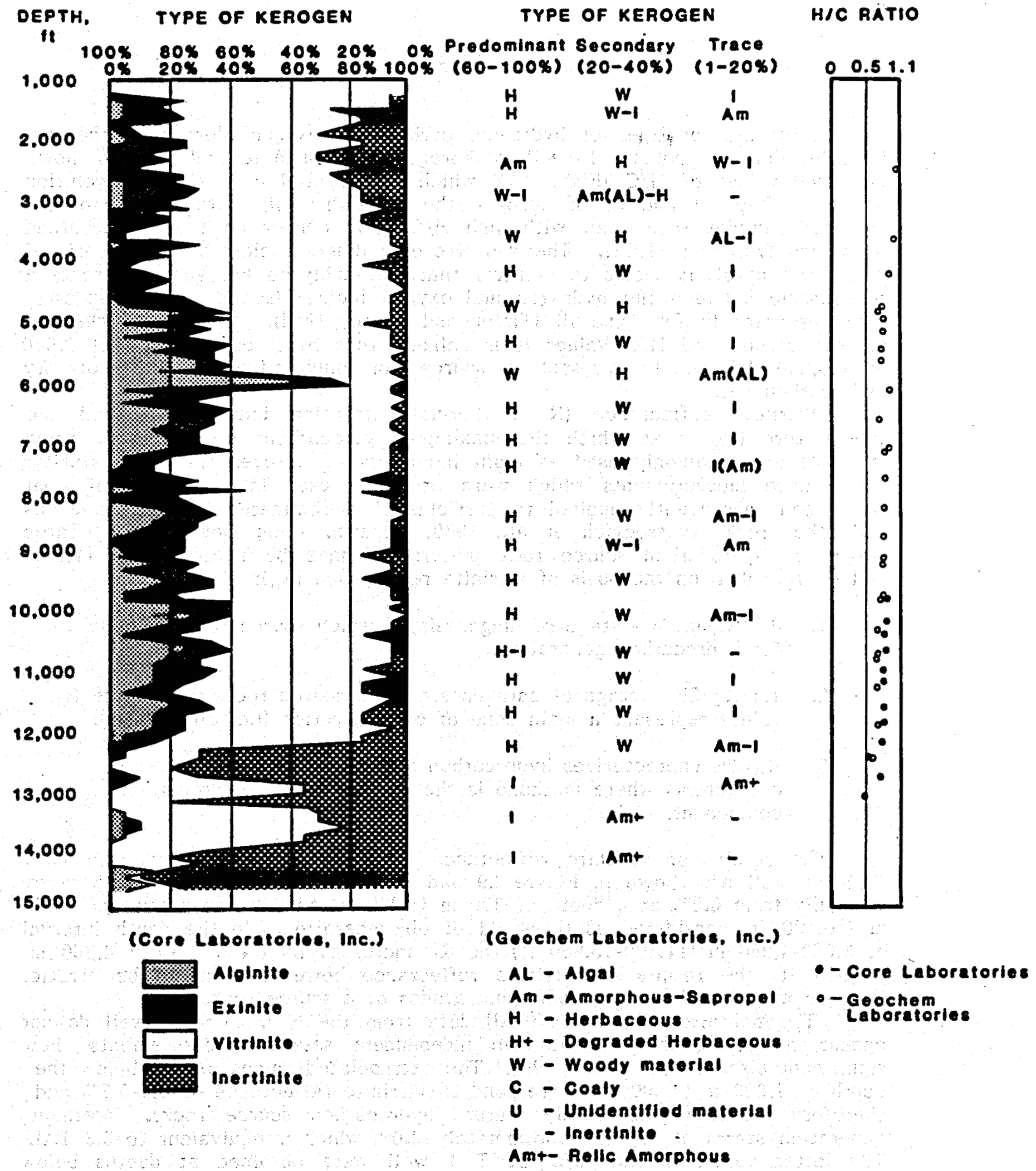

Figure 27. CLASSIFICATION OF ORGANIC MATTER IN THE PROFILE OF NORTON BASIN COST NO. 1 WELL 
Elemental analyses of hydrogen, carbon and oxygen plotted on the van Krevelen diagram indicate Type III of kerogen. Although several samples show increased values of $\mathrm{H} / \mathrm{C}$ (Figure 28) which are located between the evolution paths for Type II and III of kerogen the possibility of contamination of the analyzed samples with coal, with high $\mathrm{H} / \mathrm{C}$ ratio cannot be readily discarded (Dow and O'Connor, 1981). The van Krevelen diagram plotted on the basis of data from pyrolysis seems to confirm that the analyzed kerogen represents a relationship between the hydrogen and oxygen indices (see discussion on page 44) characteristic for Type III (Tissot and Welte, 1984). In view of the low organic carbon and $\mathrm{H} / \mathrm{C}$ values it is unlikely that rocks below depth of 3,960 $\mathrm{m}(13,000 \mathrm{ft})$ could represent a source for only minor amounts of dry hydrocarbon gas.

Vitrinite reflectance $\left(R_{0}\right)$, thermal alteration index (TAI), and the temperature $\left(T_{2 \max }\right)$ at which the maximum hydrocarbons are released during pyrolysis are commonly used as main indicators of kerogen thermal maturity. Reflectance measurements which were originally used in evaluation of coal have been subsequently applied to particles of disseminated kerogen in shales and other rocks (Vassoevich et al., 1969; Lopatin, 1969; Dow, 1977). Three stages of hydrocarbon source rock maturation have been established (Tissot and Welte, 1984) on the basis of vitrinite reflectance $\left(R_{0}\right)$ :

1. $0.5<R_{0}<0.7 \%$ - stage of diagenesis at which source rock is immature for hydrocarbon generation.

2. $1.3<R_{0}<2 \%$ - stage of catagenesis. The source rocks with these $R_{0}$ values represent a main zone of oil generation (i.e. oil window).

3. $R_{0}<2 \%$ characterizes hydrocarbon source rocks at the stage of catagenesis where methane is the only remaining hydrocarbon component.

The results of vitrinite reflectance measurements $\left(R_{0}\right)$ from the N.B. COST 1 well are shown in Figure 29 and Table 3. The values of $R_{0}$ increase gradually from $0.2 \%$ at a depth of $300 \mathrm{~m}(1,000 \mathrm{ft})$ to $0.7 \%$ at depth of 3,079 $\mathrm{m}(10,100 \mathrm{ft})$ considered as threshold of oil generation. In the depth interval of $3,080-4,260 \mathrm{~m}(11,100-13,980 \mathrm{ft})$ the Ro increases to $1.4 \%$. Below $4,260 \mathrm{~m}$ $(13,980 \mathrm{ft})$ the results of vitrinite reflectance however seem to be erratic, indicate metagenetic and metamorphic grades of a source rock.

Thermal alteration index (TAI) data from the N.B. COST 1 well do not appear to be reliable as the two independent sets of measurements show significant discordances (Figure 29). The extrapolated values of TAI below the depth of $2,890 \mathrm{~m}(9,500 \mathrm{ft})$ correspond to vitrinite reflectance of $0.6-0.7 \%$ and therefore represent moderately mature hydrocarbon source rocks. Methane generation starts at $R_{0}$ of approximately $2.0 \%$ which is equivalent to $3.8 \mathrm{TAI}$. The latter values in the N.B. COST 1 well were obtained at depths below $3,960 \mathrm{~m}(13,000 \mathrm{ft})$.

The values of temperature at which the maximum thermal hydrocarbons are generated $\left(T_{2 \max }\right)$ during pyrolysis is often used to characterize source rock maturity for hydrocarbon generation (Claypool and Reed, 1974; Espitalie et al., 1977). The values of $T_{2 \max }$ (Figure 26) are in good correlation with $R_{0}$ and $\mathrm{TAI}$, suggesting that the optimum conditions $\left(\mathrm{T}_{2 \max }-432^{\circ} \mathrm{C}\right)$ for oil 


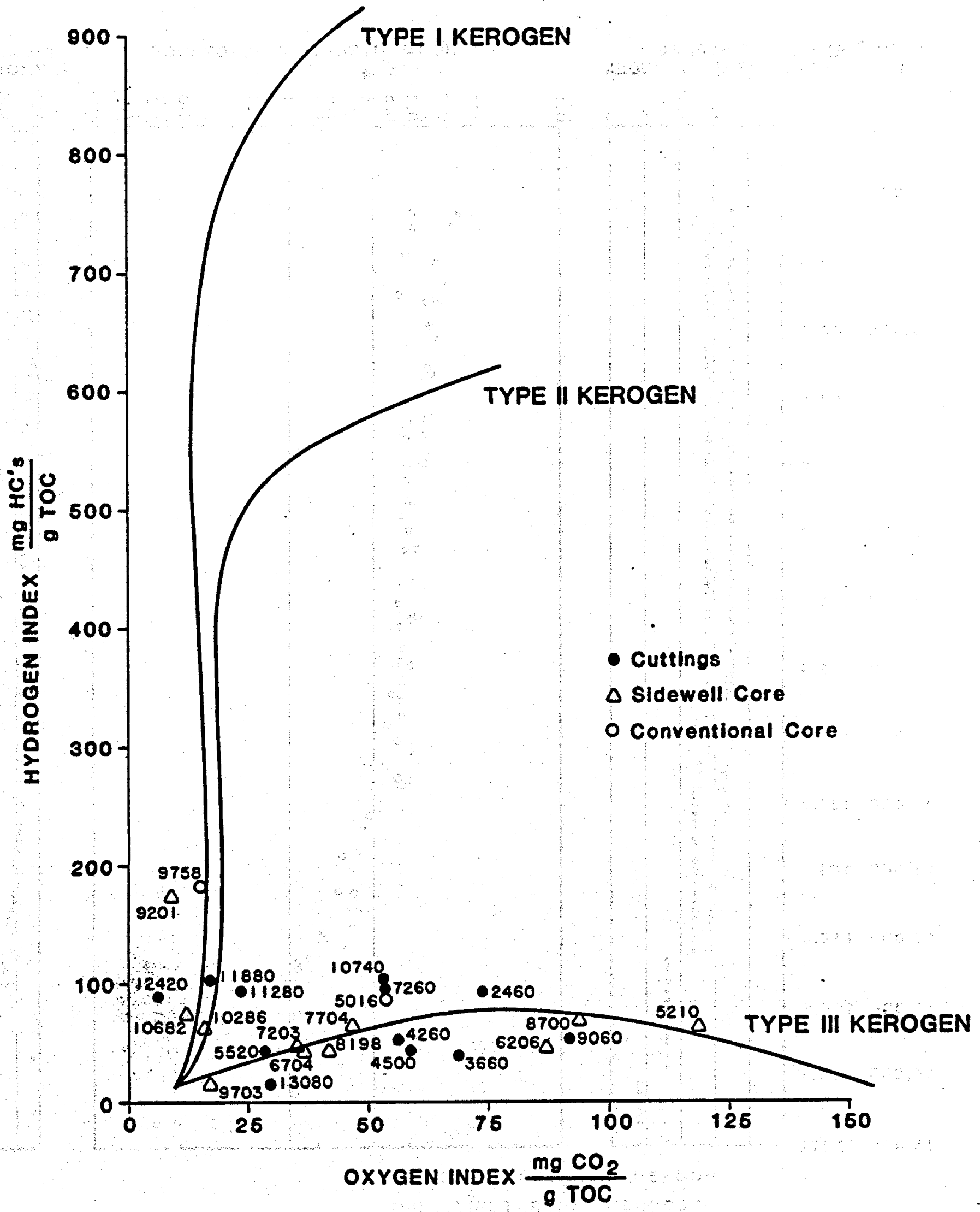

Figure 28. VAN KREVELEN DIAGRAM AND RESULTS OF PYROLYSIS ANALYSES IN NORTON BASIN COST NO. 1 WELL 


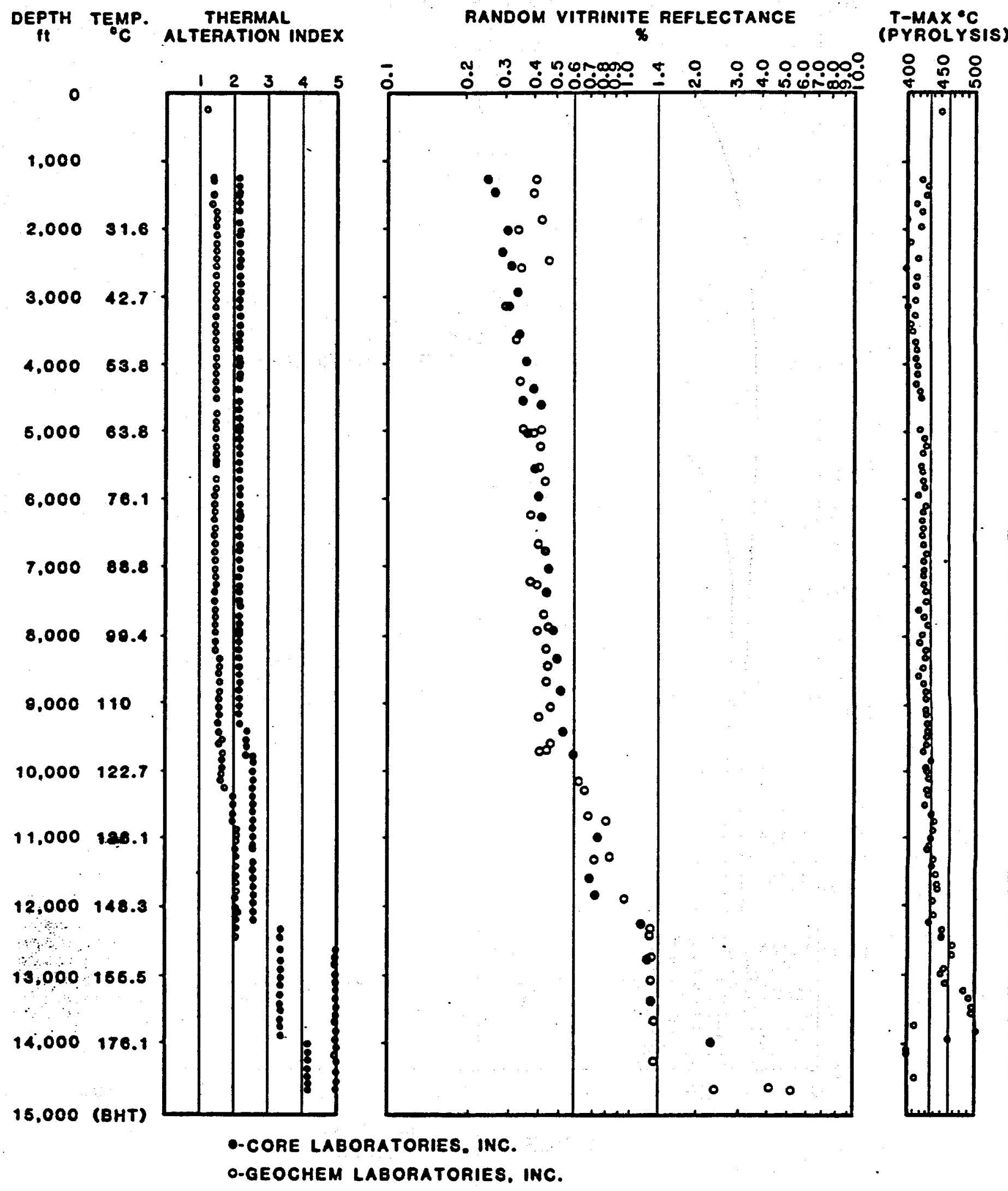

Figure 29. RESULTS OF KEROGEN ANALYSES IN NORTON BASIN COST WELL NO. 1 
ORGANIC GEOCHEMICAL DATA FROM GENERAL AREA OF NORTON SOUND After Fisher, 1982

\begin{tabular}{|c|c|c|c|c|c|c|c|c|c|}
\hline \multirow{2}{*}{\multicolumn{2}{|c|}{$\begin{array}{l}\text { Sample } \\
\text { No. }^{A} \text { Age }\end{array}$}} & \multirow[b]{2}{*}{ Lithology } & \multirow[b]{2}{*}{$\begin{array}{l}\text { Organic } \\
\text { carbon } \\
\text { percent }\end{array}$} & \multirow{2}{*}{$\begin{array}{l}\text { Average } \\
\text { vitrinite } \\
\text { reflectance, } \\
\text { percent }\end{array}$} & \multicolumn{2}{|c|}{ Indigenous Kerogen } & \multicolumn{3}{|c|}{$C_{15+}$ Extraction } \\
\hline & & & & & Type ${ }^{8}$ & $\begin{array}{l}\text { Thermal } \\
\text { alteration } \\
\text { index }\end{array}$ & $\begin{array}{l}\text { Extract, } \\
\text { ppm }\end{array}$ & $\begin{array}{l}\text { Hydrocarbon } \\
\text { in extract, } \\
\text { ppm }\end{array}$ & $\begin{array}{l}\mathrm{P}-\mathrm{N}^{\mathrm{C}} \text { in } \\
\text { extract, } \\
\text { percent }\end{array}$ \\
\hline $\begin{array}{l}\text { St. } \\
1 \\
2 \\
3\end{array}$ & $\begin{array}{l}\text { Lawrence Islar } \\
\text { Tertiary } \\
\text { Tertiary } \\
\text { Tertiary }\end{array}$ & $\begin{array}{l}\text { nd } \\
\text { Limey sandstone } \\
\text { Coaly siltstone } \\
\text { Coal }\end{array}$ & $\begin{array}{r}0.44 \\
33.18 \\
81.80\end{array}$ & $\begin{array}{l}0.24 \\
0.39 \\
0.22\end{array}$ & $\begin{array}{l}\mathrm{H}-\mathrm{W}-\mathrm{C} ;-; \mathrm{Am} \\
\mathrm{W}-\mathrm{C} ;-; \mathrm{H} \\
\mathrm{W}-\mathrm{C} ; \mathrm{H} ; \mathrm{Am}\end{array}$ & $\begin{array}{l}1.6 \\
2.0 \\
1.6\end{array}$ & 670 & $\begin{array}{c}48 \\
--- \\
---\end{array}$ & $\begin{array}{l}--- \\
---\end{array}$ \\
\hline $\begin{array}{l}4 \\
5 \\
6\end{array}$ & $\begin{array}{l}\text { Tertiary } \\
\text { Triassic } \\
\text { Triassic }\end{array}$ & $\begin{array}{l}\text { Coal } \\
\text { Shale } \\
\text { Limestone }\end{array}$ & $\begin{array}{r}52.60 \\
2.16 \\
0.16\end{array}$ & 0.39 & $\begin{array}{l}W-C ;-; A m-H \\
H-W ;-;- \\
W-C ;-; H\end{array}$ & $\begin{array}{l}2.0 \\
1.6 \\
1.6\end{array}$ & 489 & 31 & $\begin{array}{l}--- \\
---\end{array}$ \\
\hline $\begin{array}{l}9 \\
10\end{array}$ & $\begin{array}{l}\text { Permian and } \\
\text { Triassic } \\
\text { Devonian } \\
\text { Devonian }\end{array}$ & $\begin{array}{l}\text { Shale } \\
\text { Limestone } \\
\text { Dolomite }\end{array}$ & $\begin{array}{l}2.13 \\
0.29 \\
0.41\end{array}$ & $\cdots$ & $\begin{array}{l}\text { W-C;H;- } \\
\mathrm{H} ; \mathrm{W} ;- \\
\mathrm{H}-\mathrm{W} ;-;-\end{array}$ & $\begin{array}{l}3.6 \\
1.6 \\
2.0\end{array}$ & \begin{tabular}{l}
708 \\
\hdashline-- \\
439
\end{tabular} & $\begin{array}{r}70 \\
--- \\
29\end{array}$ & --- \\
\hline $\begin{array}{l}\text { Sew } \\
11 \\
11\end{array}$ & $\begin{array}{c}\text { ard Peninsula } \\
\text { Tertiary(?) } \\
\text { Tertiary(?) }\end{array}$ & $\begin{array}{l}\text { Sandstone } \\
\text { Coal }\end{array}$ & $\begin{array}{r}0.37 \\
29.29\end{array}$ & $\begin{array}{l}0.86 \\
0.92\end{array}$ & $\begin{array}{l}\mathrm{H} ; \mathrm{W} ;- \\
\mathrm{H}-\mathrm{W} ; \mathrm{C} ;-\end{array}$ & $\begin{array}{l}1.6 \\
2.8\end{array}$ & $\begin{array}{r}469 \\
7,312\end{array}$ & $\begin{array}{r}76 \\
862\end{array}$ & $\begin{array}{l}1.5 \\
0.3\end{array}$ \\
\hline $\begin{array}{l}\text { East } \\
12 \\
13 \\
14\end{array}$ & $\begin{array}{l}\text { tern shore Nor } \\
\text { Oligocene } \\
\text { Oligocene(?) } \\
\text { Oligocene }\end{array}$ & $\begin{array}{l}\text { Con Sound } \\
\text { Coal } \\
\text { Coal } \\
\text { Coal }\end{array}$ & $\begin{array}{l}26.48 \\
28.14 \\
21.03\end{array}$ & $\begin{array}{l}0.31 \\
0.32 \\
0.30\end{array}$ & $\begin{array}{l}W ; H ; A m \\
W ; H ; A m \\
H-W ;-;-\end{array}$ & $\begin{array}{l}1.2 \\
1.2 \\
1.2\end{array}$ & $\begin{array}{r}1,826 \\
160 \\
10,826\end{array}$ & $\begin{array}{r}184 \\
36^{D} \\
948\end{array}$ & \begin{tabular}{l}
0.2 \\
\hdashline 0.3
\end{tabular} \\
\hline $\begin{array}{l}15 \\
15 \\
15\end{array}$ & $\begin{array}{l}\text { Cretaceous } \\
\text { Cretaceous } \\
\text { Cretaceous }\end{array}$ & $\begin{array}{l}\text { Shale } \\
\text { Shale } \\
\text { Coaly Shale }\end{array}$ & $\begin{array}{l}0.50 \\
1.50 \\
6.58\end{array}$ & $\begin{array}{l}1.96 \\
2.53 \\
2.47\end{array}$ & $\begin{array}{l}\mathrm{H}-\mathrm{W} ; \mathrm{C} ;- \\
W-\mathrm{C} ; \mathrm{H}- \\
\mathrm{H} ; \mathrm{C} ; \mathrm{W}\end{array}$ & $\begin{array}{l}3.2 \\
2.8 \\
3.6\end{array}$ & $\begin{array}{r}70 \\
135 \\
210\end{array}$ & $\begin{array}{l}10^{\mathrm{D}} \\
32^{\mathrm{D}} \\
57\end{array}$ & $\overline{---}$ \\
\hline $\begin{array}{l}16 \\
16 \\
18\end{array}$ & $\begin{array}{l}\text { Cretaceous } \\
\text { Cretaceous } \\
\text { Cretaceous }\end{array}$ & $\begin{array}{l}\text { Shale } \\
\text { Shale } \\
\text { Coaly shale }\end{array}$ & $\begin{array}{l}0.38 \\
0.31 \\
7.37\end{array}$ & $\begin{array}{l}2.27 \\
2.42 \\
2.53\end{array}$ & $\begin{array}{l}C ; H-W ;- \\
W-C ;-; H \\
H-W ; C ;-\end{array}$ & $\begin{array}{l}3.6 \\
3.6 \\
3.2\end{array}$ & $\begin{array}{l}197 \\
138 \\
228\end{array}$ & $\begin{array}{l}38 \\
25 \\
75\end{array}$ & $\begin{array}{r}10.1 \\
-1.8\end{array}$ \\
\hline $\begin{array}{l}19 \\
19 \\
19\end{array}$ & $\begin{array}{l}\text { Cretaceous } \\
\text { Cretaceous } \\
\text { Cretaceous }\end{array}$ & $\begin{array}{l}\text { Siltstone } \\
\text { Shale } \\
\text { Coaly shale }\end{array}$ & $\begin{array}{l}1.02 \\
0.97 \\
6.01\end{array}$ & $\begin{array}{l}2.74 \\
3.22 \\
3.27\end{array}$ & $\begin{array}{l}W ; H ;- \\
H ; W ;- \\
H ;-;-\end{array}$ & $\begin{array}{l}2.4 \\
2.4 \\
3.2\end{array}$ & $\begin{array}{l}140 \\
110 \\
296\end{array}$ & $\begin{array}{l}24^{D} \\
28^{D} \\
44^{D}\end{array}$ & $\begin{array}{l}-- \\
-\cdots \\
--\end{array}$ \\
\hline $\begin{array}{l}19 \\
19 \\
19\end{array}$ & $\begin{array}{l}\text { Cretaceous } \\
\text { Cretaceous } \\
\text { Cretaceous }\end{array}$ & $\begin{array}{l}\text { Shale } \\
\text { Shale } \\
\text { Coal }\end{array}$ & $\begin{array}{r}1.87 \\
0.74 \\
14.06\end{array}$ & $\begin{array}{l}3.45 \\
1.91 \\
1.92\end{array}$ & $\begin{array}{l}\mathrm{H} ;-; W \\
\mathrm{H} ;-;- \\
W-\mathrm{C} ;-; H\end{array}$ & $\begin{array}{l}2.4 \\
3.2 \\
4.0\end{array}$ & $\begin{array}{l}179 \\
134 \\
125\end{array}$ & $\begin{array}{l}11 \\
28^{D} \\
34^{\circ}\end{array}$ & $\begin{array}{l}1.1 \\
---\end{array}$ \\
\hline $\begin{array}{l}20 \\
21 \\
21\end{array}$ & $\begin{array}{l}\text { Cretaceous } \\
\text { Cretaceous } \\
\text { Cretaceous }\end{array}$ & $\begin{array}{l}\text { Shale } \\
\text { Coal } \\
\text { Shale }\end{array}$ & $\begin{array}{r}1.33 \\
56.42 \\
0.98\end{array}$ & $\begin{array}{l}2.24 \\
1.88 \\
2.01\end{array}$ & $\begin{array}{l}W-C ; H ;- \\
W ;-; H \\
H ; W ;-\end{array}$ & $\begin{array}{l}3.2 \\
2.8 \\
2.8\end{array}$ & $\begin{array}{c}157 \\
3,321 \\
182\end{array}$ & $\begin{array}{c}48^{\circ} \\
413 \\
42^{\circ}\end{array}$ & $\overline{0.2}$ \\
\hline $\begin{array}{l}22 \\
23 \\
23\end{array}$ & $\begin{array}{l}\text { Cretaceous } \\
\text { Cretaceous } \\
\text { Cretaceous }\end{array}$ & $\begin{array}{l}\text { Shale } \\
\text { Shale } \\
\text { Shale }\end{array}$ & $\begin{array}{l}0.52 \\
0.81 \\
0.52\end{array}$ & $\begin{array}{l}2.00 \\
1.15 \\
1.19\end{array}$ & $\begin{array}{l}\mathrm{H}-W-\mathrm{C} ;-;- \\
\mathrm{H}-\mathrm{W} ;-;- \\
\mathrm{H} ;-; \mathrm{Am}-\mathrm{W}\end{array}$ & $\begin{array}{l}3.2 \\
2.0 \\
2.0\end{array}$ & $\begin{array}{l}135 \\
119 \\
249\end{array}$ & $\begin{array}{l}42^{D} \\
26^{D} \\
46\end{array}$ & $\overline{--.}$ \\
\hline 24 & Paleozoic & $\begin{array}{l}\text { Carbonaceous } \\
\text { limestone }\end{array}$ & 1.36 & 1.86 & $C ;-;-$ & 5.0 & 105 & 18 & $-\cdots$ \\
\hline
\end{tabular}

\footnotetext{
A. For locations see Figure 30 .

B. $\quad H=$ Herbaceous, spore/cuticle, $C=$ Coaly, $W=$ Woody, Am $=$ Amorphous

Kerogen types listed in order of abundance: Predominant, 100-60\%; Secondary, 40-20\%; Trace, 20-0\%.

C. $\mathrm{P}-\mathrm{N}=$ paraffins and naphthenes.

D. Estimated value.

E. Scattered values in histogram.
} 


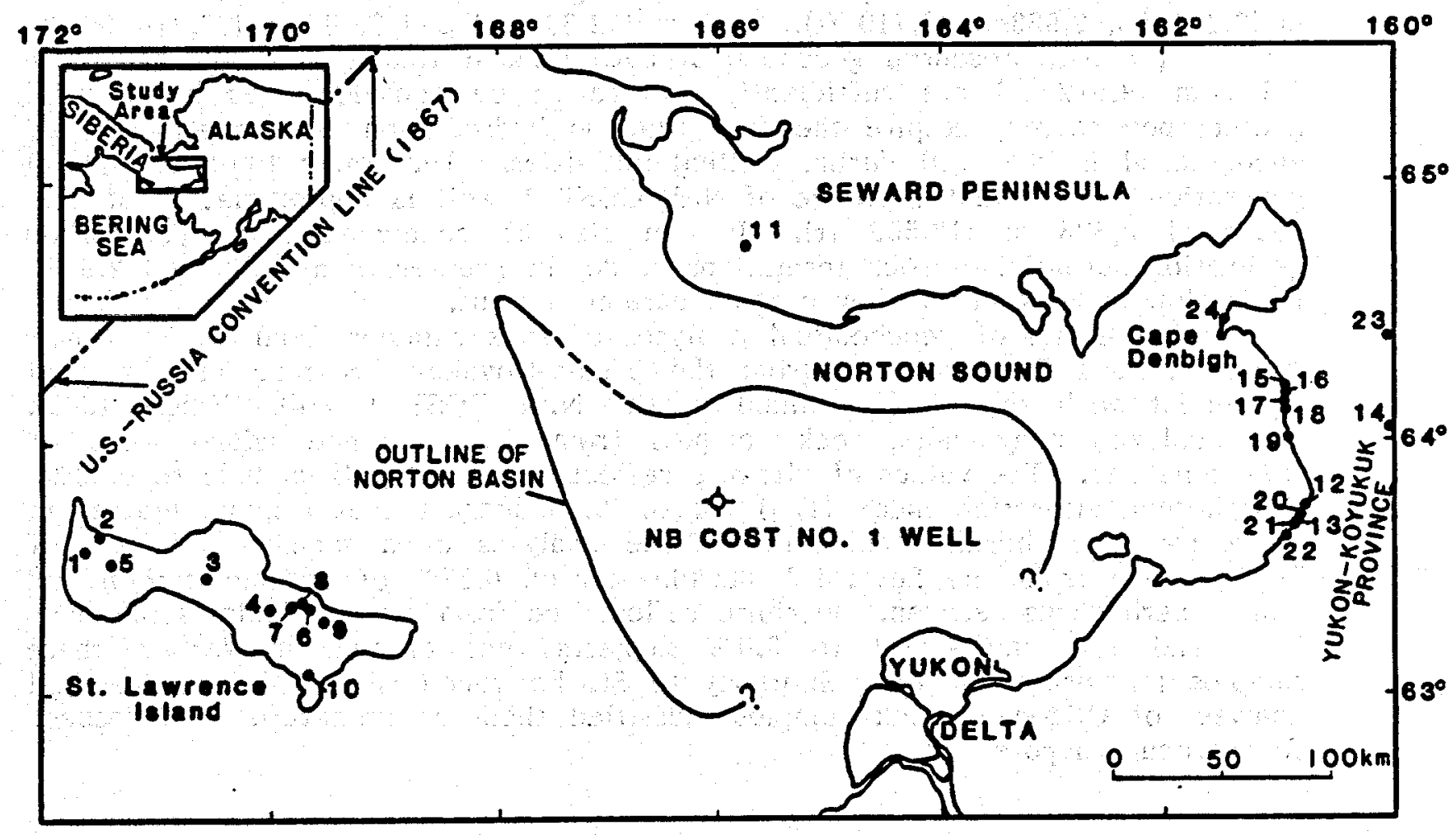

Figure 30. COLLECTION SITES OF GEOCHEMICAL SAMPLES SHOWN IN TABLE 3

After Fisher, 1982 
generation in N.B. COST 1 well occur at about $2,900 \mathrm{~m}(9,500 \mathrm{ft})$. The poor quality of the geochemical data below $3,650 \mathrm{~m}(12,000 \mathrm{ft})$ do not permit reliable interpretation. Although all geochemical analyses of the rock samples from the N.B. COST 1 well including Rock-Eval pyrolysis are strongly influenced by presence of coal, the results of pyrolysis suggest that relatively good source rock potential for hydrocarbons $\left(\left(S_{1}+S_{2}\right)=6,000\right)$ occurs at intervals 2,805 m $(9,201 \mathrm{ft}), 2,963 \mathrm{~m}(9,719 \mathrm{ft}), 3,750 \mathrm{~m}(12,300 \mathrm{ft})$ and $3,786 \mathrm{~m}(12,418 \mathrm{ft})$.

All above presented geochemical data suggest that the sediments below $2,900 \mathrm{~m}(9,512 \mathrm{ft})$ are sufficiently mature to be considered as a potential hydrocarbon source, despite the fact that no hydrocarbon accumulations were encountered in the well during drilling activities. The lower limit of the oil generation window in the profile of N.B. COST 1 well is approximately at the depth of $3,826 \mathrm{~m}(12,550 \mathrm{ft})$. It can also be concluded that hydrocarbon generation potential of rock formations at depths greater than $3,960 \mathrm{~m}(12,988$ $\mathrm{ft}$ ) is slim in view of the low organic carbon content.

The results of geochemical analyses of rock samples from St. Lawrence Island, Seward Peninsula and from the Yukon-Koyukuk Province are in good agreement with the data obtained in the N.B. COST 1 well (Fisher, 1982). The analyzed nonvolcanic rock samples from St. Lawrence Island were of Oligocene age. The values of vitrinite reflectance ranging from 0.22 to $0.39 \%$ and thermal alteration index (TAI) 1.4 to $2.2 \%$ suggest that organic matter in those rocks is thermally immature. The analyses of a sandstone sample of Tertiary age from the Seward Peninsula showed $0.37 \%$ of organic carbon and mainly herbaceous kerogen. Vitrinite reflectance from several samples of near $0.9 \%$ and TAI values 1.4 to $3.0 \%$ suggests that organic matter in these samples is mature for oil. Similarly to St. Lawrence Island, the geochemical analyses of Oligocene rock samples classified them as immature with respect to hydrocarbon potential.

\section{Hydrocarbon Generation}

The projection of hydrocarbon generation potential in the Norton Basin presented by Fisher (1982; Figure 31) appears to be consistent with geological data available at the present time. Major conclusions from this projection can be summarized as follows:

1. The window of oil generation in the Norton Basin is at a depth interval of 2,900-3,960 $\mathrm{m}$ (i.e. 9,512-12,988 ft) assuming a geothermal gradient of $3.9^{\circ} \mathrm{C} / 100$.

2. Thermogenic hydrocarbon gas can potentially be generated at depths from $4,700 \mathrm{~m}$ to $6,000 \mathrm{~m}(15,416-19,680 \mathrm{ft})$.

3. Considering the relatively thin sedimentary sequence in the predominant part of the Norton Basin, only very limited deep parts of the basin are favorable for generation of thermogenic hydrocarbon gas. 
$-65-$

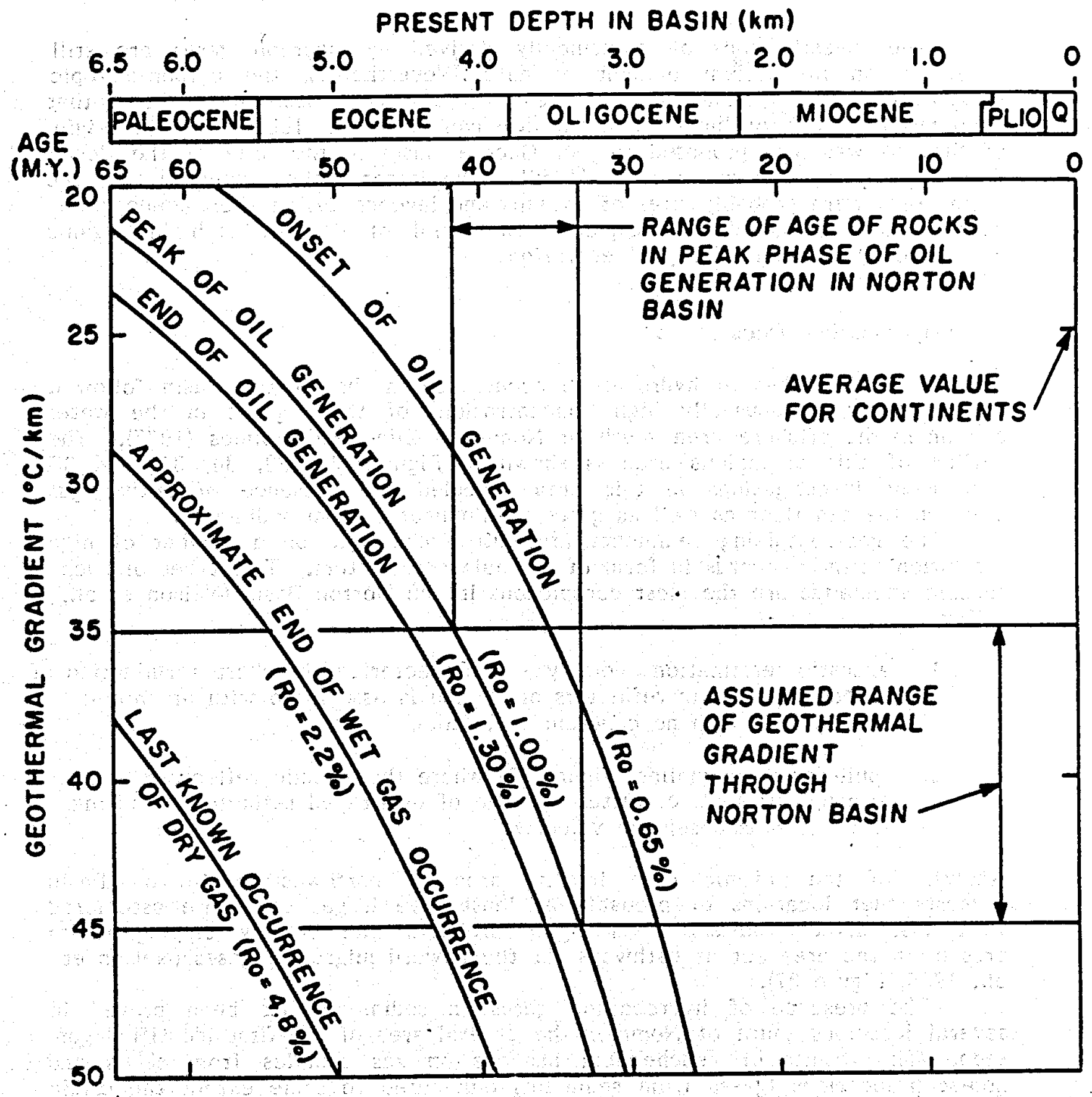

Figure 31. PROJECTION OF HYDROCARBON GENERATION IN NORTON BASIN

After Fisher, 1982 
The investigations of biogenically derived hydrocarbon gases are still based on an insufficient amount of data. Nevertheless, the carbon-isotopic analyses of samples from shallow cores in the Norton Basin have shown that hydrocarbon gas is of biogenic origin (Kvenvolden et al., 1981). Similar origin of the gas was also proposed for St. George Basin in the area of the Bering Sea shelf by Marlow and Cooper (1980). The latter authors contend that the basin areas were probably sites of swamps and lagoons during Pleistocene time with a low sea level. Subsequent fast burial of deposits rich in organic carbon resulted in biogenic gas generation.

\section{Hydrocarbon Occurrence}

Detailed studies of hydrocarbon occurrence in the Norton Basin followed the discovery of unusually high concentrations of these gases in the water column in the of fshore area south of Nome by Cline and Holmes (1977). The outline of this anomalous area is shown in Figures 32,33,34, 35, and 36 . Subsequent investigations in this area revealed the presence of active gas seeps in the sea floor as well as gases within near bottom sediments.

The gas-containing sediments are quite noticeable on a number of high resolution seismic records in form of anomalous reflectors. Two types of such seismic anomalies are the most conspicuous in the Norton Basin (Nelson et al., 1978):

1. acoustic termination anomaly - is characterized by sharp termination of subbottom seismic reflectors and of ten is associated with an intervening zone with no coherent reflectors,

2. "pull-down" anomalies (Figure 37) where the seismic reflectors, although present, constitute a zone of disarrayed reflectors resulting from decreased seismic velocity.

Analysis of the seismic data in the area of northwestern Norton Basin suggests that locations of probably at least several gas seeps are associated with near-surface faults. It is highly probable that steeply dipping faults present in the area act as pathways for the upward migrating gases (Nelson et al., 1985; Figure 37).

The presence of hydrocarbon gases in sediments has been proved in several locations south of Nome in the general area of the first identified gas seep. The results of geochemical analysis on gas samples from seeps and non-seep locations (gases from sediment) elucidated to some extent the origin of the gases. Some of these results, however, do not permit the conclusive assessment of the processes responsible for gas generation.

Hydrocarbon Gas in Water Column. According to Cline (1976) and Holmes (1977) relatively high concentration of $C_{2}$ to $C_{4}$ alkanes were detected in the of fshore area of Norton Basin about $40 \mathrm{~km}$ south of Nome where sea depth is $20 \mathrm{~m}(66 \mathrm{ft})$. The ethane-bearing waters continue westward to $168^{\circ} \mathrm{W}$ longitude. The shape of the plume appears to conform with weak sea current flowing north and transporting the gas away from the source location. The concentrations of various gas components are shown in Figures 33, 34, 


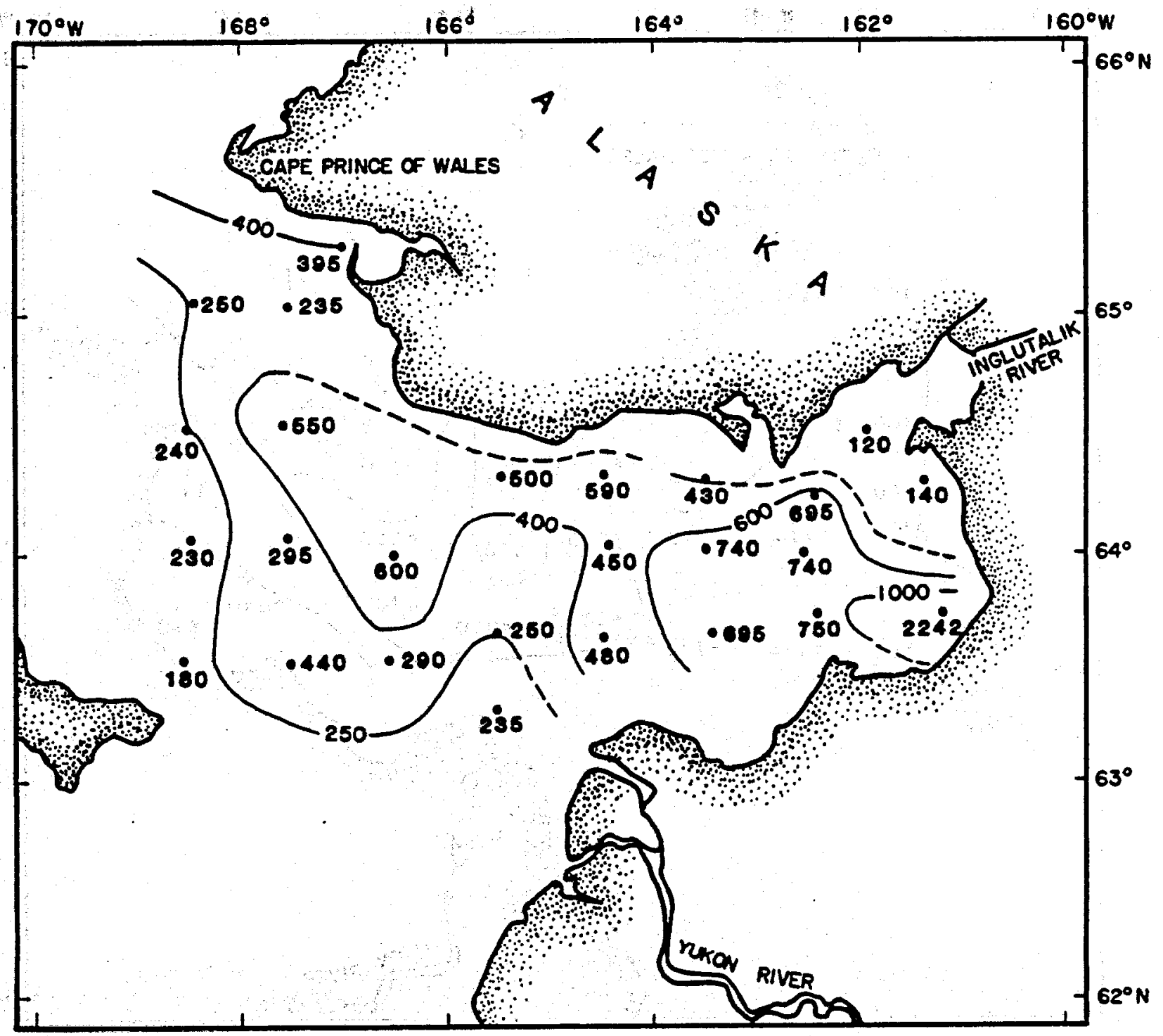

FIgure 32. DISTRIBUTION OF $\mathrm{CH}_{4}$ IN WATER $5 \mathrm{~m}$ ABOVE THE SEAFLOOR IN $\mathrm{nIII}$ (STP) IN THE NORTON SOUND AREA - SEPTEMBER 1976 After Cline, 1976 


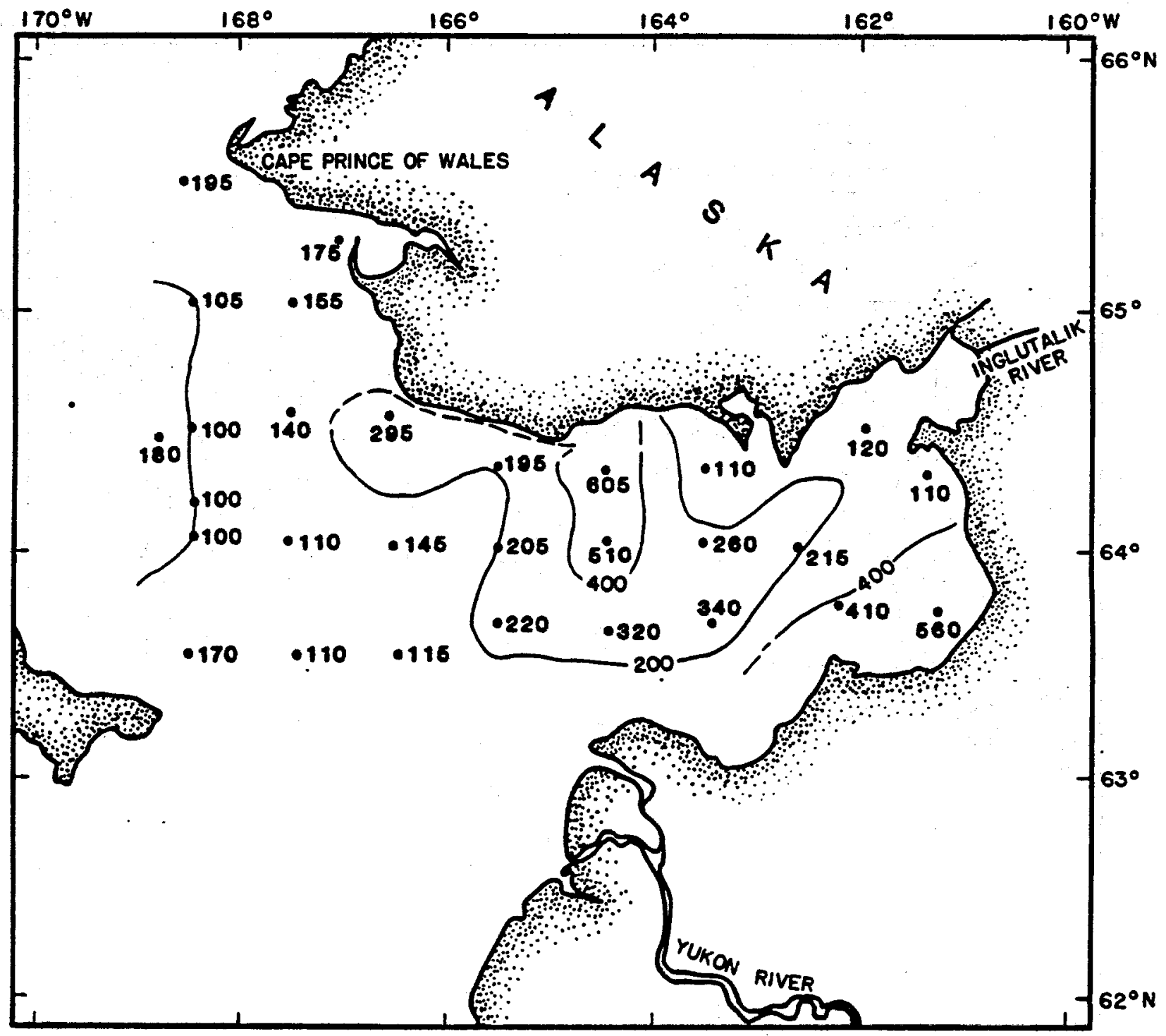

Figure 33. DISTRIBUTION OF $\mathrm{CH}_{4}$ IN SURFACE WATER IN nI/I (STP) IN THE NORTON SOUND AREA - SEPTEMBER 1976 After Cline, 1976 


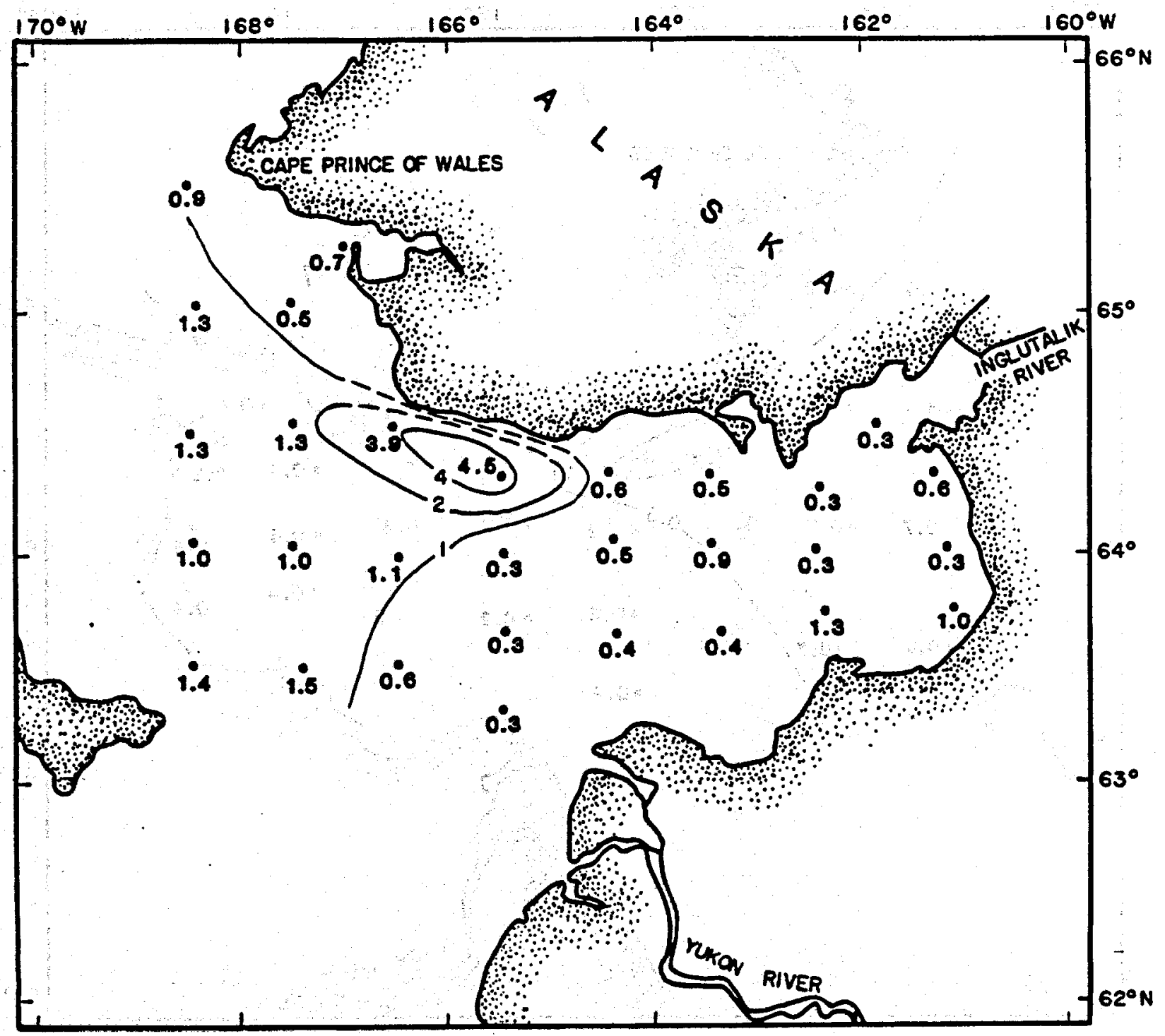

GAS CONCENTRATIONS ARE IN mI/I OF THE SEA WATER.

Figure 34. DISTRIBUTION OF ETHANE IN WATER $5 \mathrm{~m}$ ABOVE THE SEAFLOOR IN THE NORTON SOUND AREA SEPTEMBER 1976

After Cline, 1976 


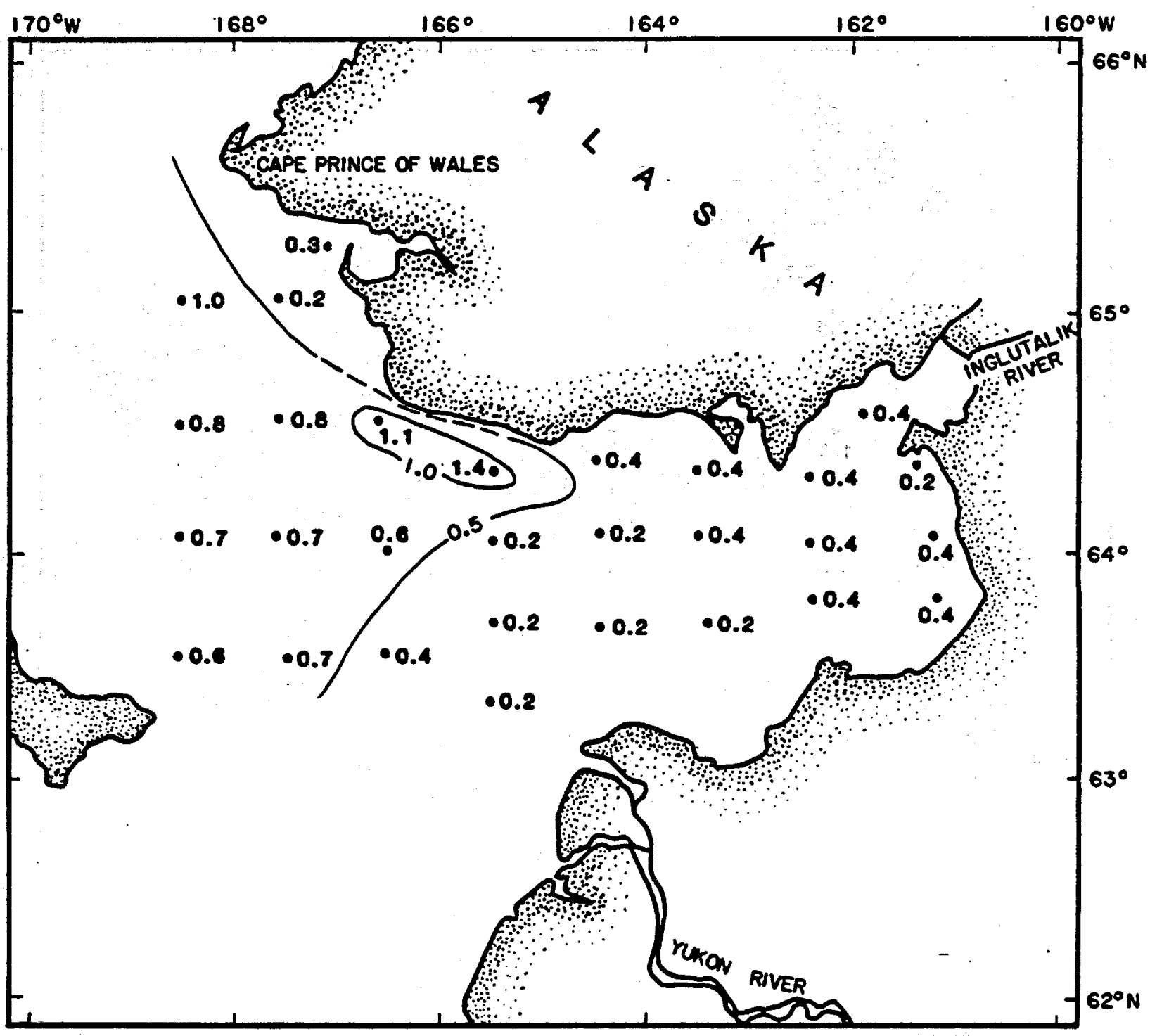

Figure 35. DISTRIBUTION OF $\mathrm{C}_{3} \mathrm{H}_{8}$ IN WATER $5 \mathrm{~m}$ ABOVE THE SEAFLOOR IN $n I / /$ (STP) IN THE NORTON SOUND AREA - SEPTEMBER 1976

After Cline, 1976 


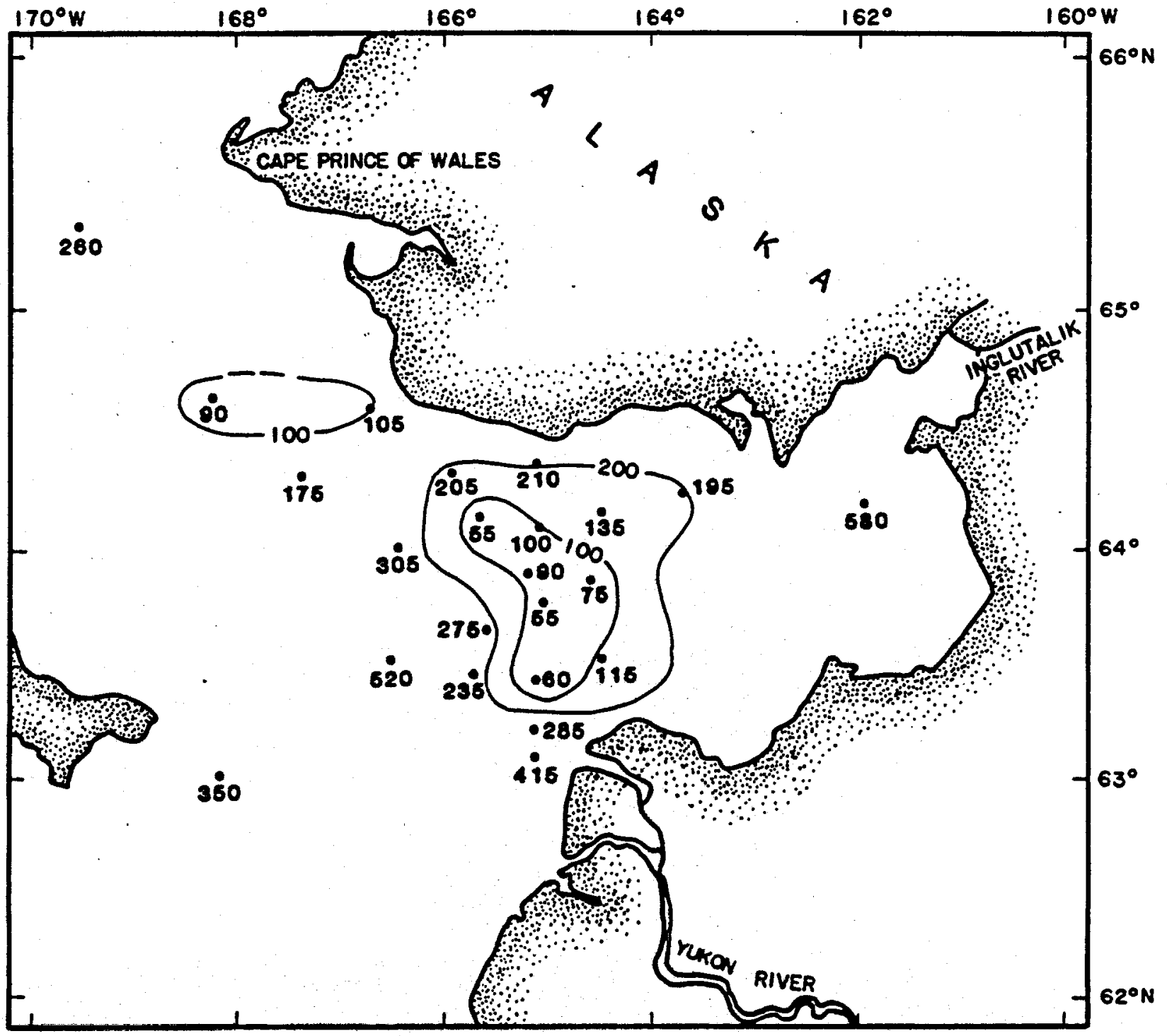

Figure 36. DIAGRAM ILLUSTRATING RATIO $\mathrm{C}_{1} / \mathrm{C}_{2}+\mathrm{C}_{3}$ HYDROCARBONS IN WATER $5 \mathrm{~m}$ ABOVE THE SEAFLOOR IN THE NORTON SOUND AREA - SEPTEMBER 1976 


\section{$\sqrt{-12}$}
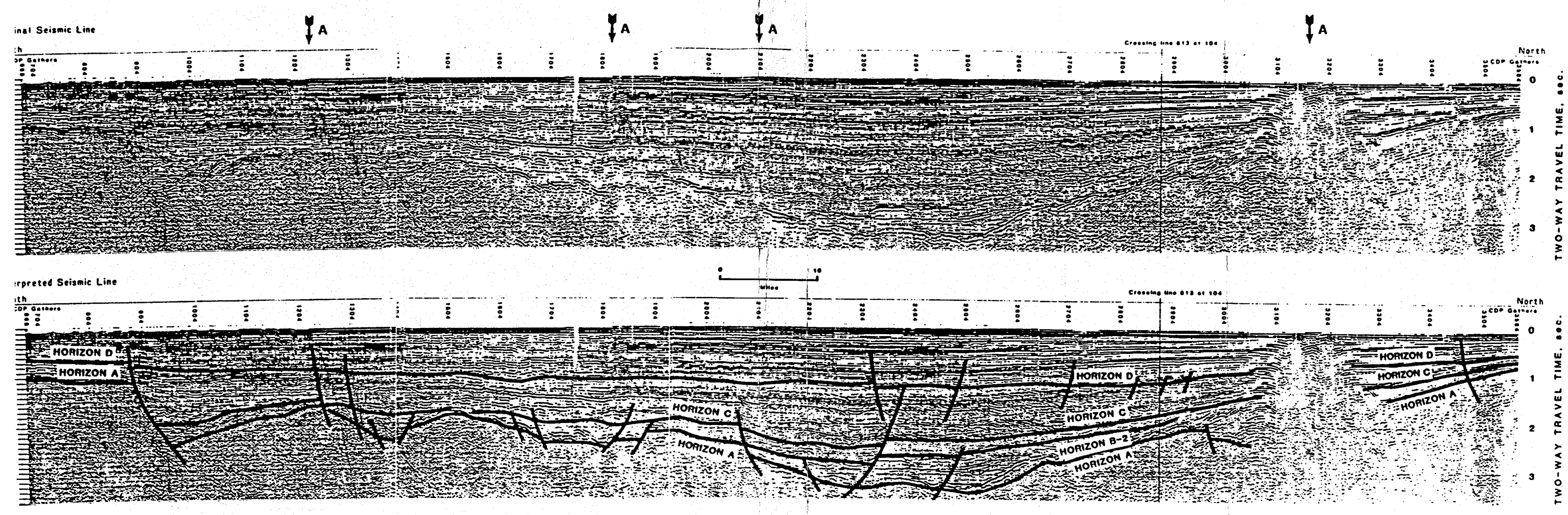

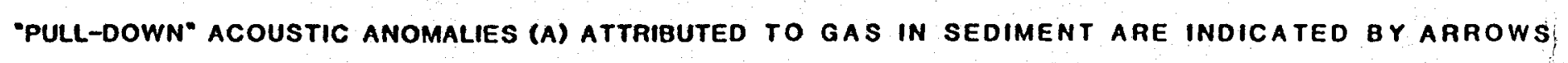

Figure 37. USGS SEISMIC LINE 802, NORTON BASIN 
and 35. Similar data from a station located at the gas seep and from another measuring station $15 \mathrm{~km}$ south from the seep are displayed in Table 4. The concentrations of methane in the near bottom sea water throughout

\section{TABLE 4.}

DISSOLVED HYDROCARBON CONCENTRATIONS WITHIN 5 m OF THE SEA FLOOR, AT THE TWO STATIONS IN NORTON BASIN. STATION N18F* IS LOCATED NEAR THE GAS SEEP LOCUS, STATION N13** IS LOCATED $15 \mathrm{~km}$ SOUTH OF THE STATION N18F. After Cline and Holmes, 1977

\begin{tabular}{|c|c|c|c|c|c|c|c|c|c|c|}
\hline \multirow{3}{*}{$\begin{array}{l}\text { Sta- } \\
\text { tion }\end{array}$} & \multirow{3}{*}{$\underset{\mathbf{m}}{\text { Depth }}$} & \multicolumn{7}{|c|}{ Concentration of Dissolved Hydrocarbon, $\mathrm{nl} / 1$} & \multirow{2}{*}{$C_{2}$} & \multirow{2}{*}{$\mathbf{C}_{1}$} \\
\hline & & \multirow{2}{*}{$\begin{array}{l}\text { Meth- } \\
\text { ane }\end{array}$} & \multirow{2}{*}{$\begin{array}{l}\text { Eth- } \\
\text { ane }\end{array}$} & \multirow{2}{*}{$\begin{array}{l}\text { Eth- } \\
\text { ene } \\
\end{array}$} & \multirow{2}{*}{$\begin{array}{l}\text { Pro- } \\
\text { pane }\end{array}$} & \multirow{2}{*}{$\begin{array}{l}\text { Pro- } \\
\text { pene }\end{array}$} & \multirow{2}{*}{$\begin{array}{l}\text { Isobu- } \\
\text { tane }\end{array}$} & \multirow{2}{*}{$\begin{array}{l}\text { n-Bu- } \\
\text { tane }\end{array}$} & & \\
\hline & & & & & & & & & $\mathbf{C}_{\mathbf{2 1}}$ & $\mathbf{C}_{2}+\mathbf{C}_{3}$ \\
\hline $\begin{array}{l}\text { N18F } \\
\text { N13 }\end{array}$ & $\begin{array}{l}17 \\
17\end{array}$ & $\begin{array}{l}525 \\
219\end{array}$ & $\begin{array}{l}9.6 \\
0.3\end{array}$ & $\begin{array}{l}1.5 \\
1.2\end{array}$ & $\begin{array}{l}3.3 \\
0.2\end{array}$ & $\begin{array}{l}0.4 \\
0.4\end{array}$ & $\begin{array}{c}0.5 \\
<0.03\end{array}$ & $\begin{array}{c}0.6 \\
<0.03\end{array}$ & $\begin{array}{l}6.4 \\
0.2\end{array}$ & $\begin{array}{r}50 \\
413\end{array}$ \\
\hline
\end{tabular}

*Station N18F - 64.07.3' $\mathrm{N}$ and $165^{\circ} 29.5^{\prime} \mathrm{W}$

**Station N13 - $63^{\circ} 59.7^{\prime} \mathrm{N}$ and $165^{\circ} 29.7^{\prime} \mathrm{W}$

Norton Basin range from 250 to $740 \mathrm{nl} / \mathrm{l}$. Under the pressure of 2 atm $(29$ psi) the threshold of water saturation in methane at which a gas bubble could form is $1 \mathrm{x} \cdot 10^{8} \mathrm{nl} / \mathrm{l}$. Such gross undersaturation can also be observed with regard to propane, ethane, and butane. Considerably weak oxidation of the methane dissolved in water in the shelf areas of Alaska (Holmes, 1977) and low partial pressure and dissolution of methane (Figures 32, 33, 34, and 35) seem to suggest a relatively small influx of hydrocarbon gas at the seeping site. Comparing the concentrations of $C_{1}, C_{2}$ and $C_{3}$ it is noticeable that methane is more uniformly distributed through the area (Figures 32 and 33) than the two other components. This observation appears to be in agreement with ratios of $\mathrm{C}_{2} / \mathrm{C}_{2=}$ (i.e. ethane/ethene). The latter ratios were used as important prospecting parameters by Barnard et al. (1976). Values of $C_{1} / C_{2}$ $+C_{3}$ greater than 1,000 indicate biogenic provenance of the hydrocarbons. Conversely values smaller than 50 are indicative of thermogenic gases. Values of $C_{1} / C_{2}+C_{3}$ between 50 and 1,000 are attributed to $a$ mixed source of hydrocarbons. Based on measured values of $C_{1}, C_{2}$ and $C_{3}$ in water, the ratios of $C_{1} / C_{2}+C_{3}$ in the Norton Basin range from 50 to 580 (Figure 36; Table 4) implying a dual origin for the hydrocarbons. The importance of the $\mathrm{C}_{2} / \mathrm{C}_{2=}$ ratio in evaluating hydrocarbon origin was stressed by Cline and Holmes (1977). Interpretation of this ratio is based on the principle that while ethene $\left(C_{2=}\right)$ can be derived only from recent biogenic processes, ethane can originate both biogenically and thermogenically. According to this indicator increased values of $\mathrm{C}_{2} / \mathrm{C}_{2}$ are characteristic for thermogenic gas. The geochemical data from the gas seep location N18F (Table 4) show characteristics of thermogenic gas with regard to the above mentioned ratios. Similar data from the site located $15 \mathrm{~km}$ south of the seep show an increased role of the biogenically derived hydrocarbons. The estimates of the $C_{2} / C_{3}$ mole ratio in the seep gas provided more evidence for thermogenic origin of the gas. According to these estimates (Holmes, 1977) the hydrocarbon deposits from which the gas at the seep site may leak also contains liquid hydrocarbons. 
Hydrocarbons in Sediment. The presence of hydrocarbon gas in near bottom sediments were reported by Kvenvolden et al. (1979) from two sites (Figure 38) in Norton Basin. One of these sites (Site 3, Figure 38) represented by a gas seep is located "approximately $50 \mathrm{~km}$ south of Nome at a water depth of $19 \mathrm{~m}^{n}$. Although this site is located in the same general area as a previously described gas seep site discovered by Cline and Holmes. On the basis of papers presented by Kvenvolden et al. $(1979 \mathrm{a} ; 1979 \mathrm{~b})$ we were unable to verify how far apart the two sites are located or if both locations represent the same site. Geochemical investigations of hydrocarbon gases by the latter authors revealed the presence of light and heavier molecular hydrocarbons, including gasoline range $\left(C_{5^{+}}\right)$hydrocarbons (Table 5). The amount of these hydrocarbons, however anomalous, was still found to be below a water saturation level. The most interesting aspect of these results was discovery that hydrocarbons constitute only a minor component of the seep gas and $\mathrm{CO}_{2}$ is a major. gas "bubbling" from the sea floor. Carbon dioxide $\left(\mathrm{CO}_{2}\right)$ composes $98 \%$ of the gas mixture. While the possibility of contamination of the gas sample was eliminated, the isotopic analyses indicated that the $\mathrm{CO}_{2}$ originated from thermal processes (Table 5). Kvenvolden et al. (1979)

\section{TABLE 5.}

CHEMICAL AND ISOTOPIC COMPOSITION OF GAS AT SITES 3 (GAS SEEP) AND 4 (GAS FROM SEDIMENT)* IN NORTON BASIN AREA

After Kvenvolden et al., 1979

\begin{tabular}{|c|c|c|c|c|}
\hline \multirow[t]{2}{*}{ COMPONENT } & \multicolumn{2}{|c|}{$\begin{array}{l}\text { PERCENT BY } \\
\text { VOLUME }\end{array}$} & \multicolumn{2}{|c|}{$\delta^{13} c, 0 / 00$} \\
\hline & STTE 3 & SITE 4 & SITE 3 & SITE 4 \\
\hline $\begin{array}{l}\mathrm{CO}_{2} \\
\mathrm{~N}_{2} \\
\mathrm{O}_{2} \\
\mathrm{Ar} \\
\mathrm{H} 2 \\
\mathrm{He} \\
\mathrm{H}_{2} \mathrm{O} \\
\mathrm{Methane}\left(\mathrm{C}_{1}\right) \\
\text { Ethane }\left(\mathrm{C}_{2}\right) \\
\text { Ethene } \\
\text { Propane }\left(\mathrm{C}_{3}\right) \\
\text { Propene } \\
\text { n-Butane }\left(\mathrm{n}-\mathrm{C}_{4}\right) \\
\text { Isobutane }\left(\mathrm{i}-\mathrm{C}_{4}\right)\end{array}$ & $\begin{array}{c}98 \\
-\quad 1.9 \\
0.05 \\
0.03 \\
0.01 \\
<0.01 \\
\text { Trace } \\
0.0360 \\
0.0039 \\
0.0018 \\
\\
0.0004 \\
0.0020\end{array}$ & $\begin{array}{l}75 \\
0.0019 \\
0.0001 \\
0.0013 \\
0.0001 \\
0.0004 \\
0.0009\end{array}$ & $-2.7 \pm 0.1$ & $-80.5 \pm 0.2$ \\
\hline
\end{tabular}

*Locations of Sites 3 and 4 are shown on Figure 38.

suggested thermal decarbonation of carbonate marine rocks underlying the area as the most probable source of the detected $\mathrm{CO}_{2}$. Such an interpretation is compatible with the ratio of $C_{1} / C_{2}+C_{3}$ (Barnard et al., 1976) and isotopic values $\left(\delta^{1} \mathrm{C}\right)$ of gas sample from the seep gas which indicate the thermogenic origin of the gas. 


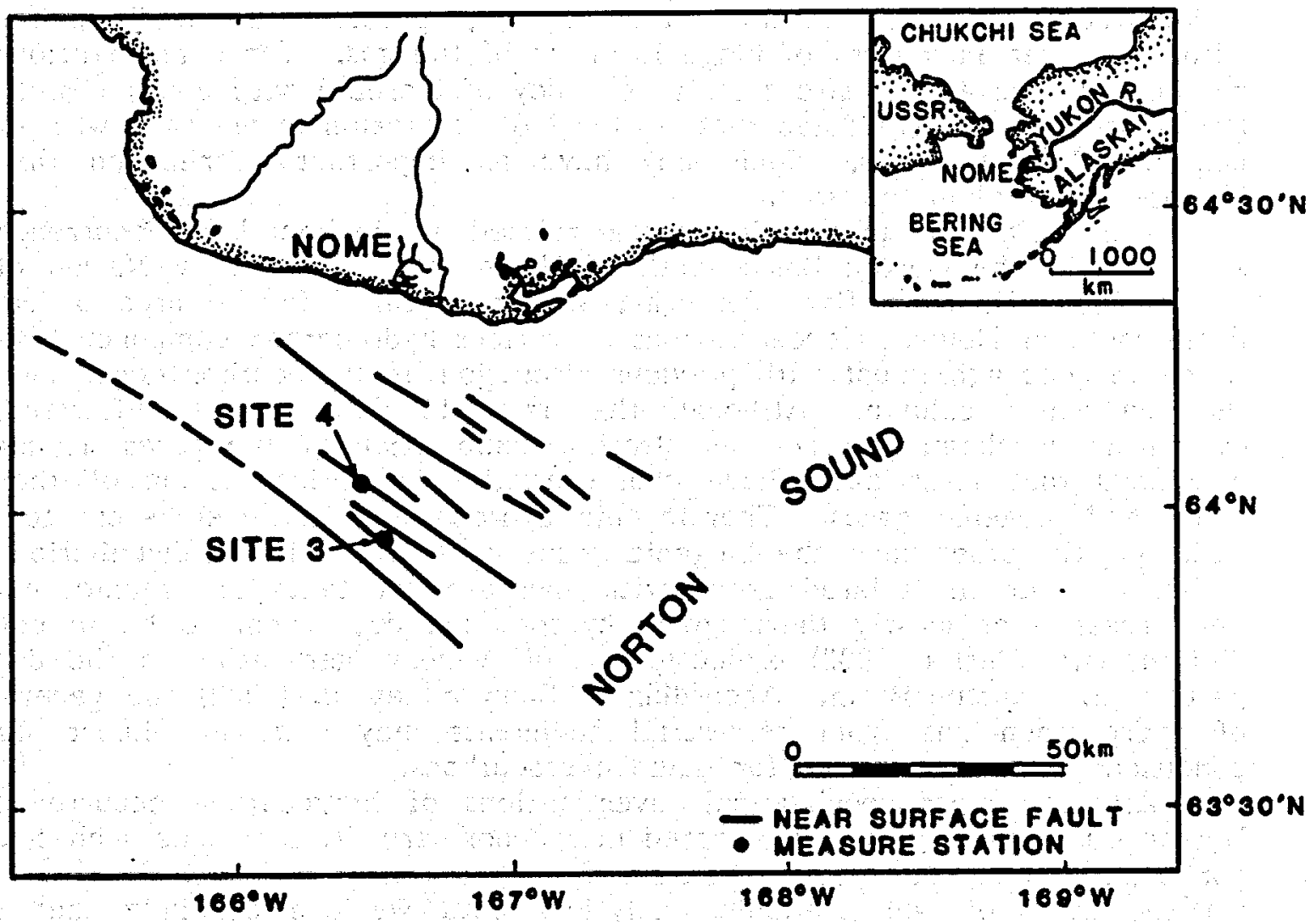

igure 38. LOCATION OF TWO SITES WITH DOCUMENTED GAS SEEP (SITE 3) AND SEDIMENT SATURATED WITH HYDROCARBON GAS

After Kvenvolden et al., 1979 
The geochemical analyses of gas from sediment at Site 4 (Tables 5 and 6) yielded significantly different results from all other sites in the area (Table 7). The analyzed gas has all previously discussed features which are characteristic for biogenic gases. The elevated value of the ethane/ethene ratio, particularly at the interval of $90-199 \mathrm{~cm}$, appears to be in disagreement with the other indicators of biogenic origin of the gas. The concentrations of hydrocarbon gas at this site show a tendency of increase with depth (Table 6). Pore water analyses revealed that its level of saturation in methane was at or near the bubble points, which may have an important bearing on the gas hydrate potential in the area.

The series of geochemical data related to hydrocarbon occurrence in sediments of the Norton Basin south of Nome was published by Nelson et al. (1978; Table 7), from five measuring stations located in the area of Norton Basin south of Nome. Concentrations of various hydrocarbon components seem to be in good agreement with previous discussion of hydrocarbon occurrence in the sea water column. Although the available data is not sufficient for evaluating geochemical processes altering composition of the gases, it can be concluded that most gases have characteristics indicating mixing of thermogenic and biogenic gases. Thermogenic hydrocarbons, however, seem to prevail. On the other hand the biogenic gases have less uniform distribution and probably occur in isolated areas with increased contents of organic matter: The presence of mostly thermogenic hydrocarbon does seem to be in contradiction with Flett's (1983) projection of oil window generation in the deepest parts of the Norton Basin. According to Snowdon et al. (1982) the generation of hydrocarbon gas from terrestrial sediments may start at almost similar conditions as those required for liquid hydrocarbons.

Although most geochemical investigations of hydrocarbon occurrence in Norton Basin have been concentrated in the northern St. Lawrence subbasin, in our opinion the results can be extended to some degree for the entire basin. On the basis of the available analytical data we can conclude that most hydrocarbons reaching near bottom sediments are thermogenically derived. Biogenic gases are dominant only locally. However, the biogenic processes generating hydrocarbons are moderately intensive, their modification of geochemical indicators in the area is very conspicuous. In this geological context, fault systems may be important hydrocarbon migration pathways. The assessment of hydrocarbon gases in Norton Basin crucial in evaluating gas hydrates potential still requires more quantitative data including also the saturation of interstitial water with gas within 100-150 $\mathrm{m}$ of near surface sediments.

\section{Geothermal Gradient}

Corrected bottom-hole temperatures from the area of Norton Basin as well as from west-central Alaska show geothermal gradients ranging from $4.1^{\circ} \mathrm{C} / 100 \mathrm{~m}$ to $5.5^{\circ} \mathrm{C} / 100 \mathrm{~m}$. Such geothermal gradients are considerably higher than the average values in the continental areas $\left(2.5-3^{\circ} \mathrm{C} / 100 \mathrm{~m}\right)$. The measurements of geothermal gradients in the neighboring Hope Basin with a tectonic evolution similar to Norton Basin showed values near $5.0^{\circ} \mathrm{C} / 100 \mathrm{~m}$. High geothermal gradients have also been confirmed by the omnipresent seismic horizon $D$, where a change of acoustic velocity is attributed to thermally 
TABLE 6.

GAS COMPOSTION IN SEDIMENTS, NORTON BASIN*

After Kvenvolden et al., 1979

\begin{tabular}{|c|c|c|c|c|c|c|c|c|c|c|c|}
\hline & \multirow[b]{2}{*}{$\begin{array}{l}\text { Interval } \\
\text { cm }\end{array}$} & \multicolumn{8}{|c|}{ Gas Component in $n L / L$ of Interstitial Water } & \multirow[b]{2}{*}{$\frac{\text { Methane }}{\text { Ethane+Propane }}$} & \multirow[b]{2}{*}{$\frac{\text { Ethane }}{\text { Ethene }}$} \\
\hline & & $\begin{array}{l}\text { Methane } \\
\left(\times 0^{3}\right)\end{array}$ & Ethane & Ethene & Propane & Propene & n-Butane & Isobutane & $\begin{array}{l}\mathrm{CO}_{2} \\
\left(\mathrm{x} 10^{6}\right)\end{array}$ & & \\
\hline Site 3 & $\begin{array}{l}110-119 \\
200-209 \\
300-309 \\
400-409\end{array}$ & $\begin{array}{c}68 \\
4.0 \\
2.1 \\
1.5\end{array}$ & $\begin{array}{r}7300 \\
3000 \\
500 \\
\mathbf{3 4 0}\end{array}$ & $\begin{array}{r}63 \\
290 \\
56 \\
180\end{array}$ & $\begin{array}{r}220 \\
9300 \\
330 \\
440\end{array}$ & $\begin{array}{r}48 \\
200 \\
56 \\
130\end{array}$ & $\begin{array}{r}50 \\
5600 \\
280 \\
240\end{array}$ & $\begin{array}{r}640 \\
24000 \\
240 \\
94\end{array}$ & $\begin{array}{r}61 \\
110 \\
47 \\
52\end{array}$ & $\begin{array}{r}9 \\
<\quad 1 \\
3 \\
2\end{array}$ & $\begin{array}{r}120 \\
13 \\
9 \\
2\end{array}$ \\
\hline Site 4 & $\begin{array}{l}0-9 \\
50-59 \\
90-99 \\
190-199 \\
290-299 \\
390-399\end{array}$ & $\begin{array}{r}69 \\
220 \\
3500 \\
33000 \\
41000 \\
38000\end{array}$ & $\begin{array}{r}28 \\
66 \\
820 \\
830 \\
1100 \\
1000\end{array}$ & $\begin{array}{r}81 \\
170 \\
99 \\
62 \\
330 \\
330\end{array}$ & $\begin{array}{r}35 \\
45 \\
320 \\
560 \\
760 \\
910\end{array}$ & $\begin{array}{r}68 \\
66 \\
28 \\
30 \\
140 \\
230\end{array}$ & $\begin{array}{r}14 \\
- \\
34 \\
170 \\
290 \\
170\end{array}$ & $\begin{array}{r}- \\
- \\
40 \\
400 \\
640 \\
230\end{array}$ & $\begin{array}{l}0.072 \\
1.4 \\
4.6 \\
11 \\
17 \\
12\end{array}$ & $\begin{array}{r}1100 \\
2000 \\
3100 \\
2,4000 \\
20000 \\
20000\end{array}$ & $\begin{array}{c}0.4 \\
0.4 \\
8 \\
13 \\
3 \\
3\end{array}$ \\
\hline
\end{tabular}

* Concentrations are calculated on the basis of interstitial water determined from moisture content. Hydrocarbons are corrected for partitioning effects between the headspace and the sediment-water mixture in the paint cans. 
TABLE 7.

CONCENTRATIONS OF HYDROCARBONS IN CORE SEDIMENT SAMPLES FROM THE NORTON BASIN

After Nelson et al., 1978

\begin{tabular}{|c|c|c|c|c|c|c|c|c|}
\hline \multirow{2}{*}{$\begin{array}{l}\text { SAMPLE } \\
\text { INTERVAL, cm }\end{array}$} & \multicolumn{7}{|c|}{ GAS CONCENTRATIONS, nL/L } & \multirow{2}{*}{$\frac{C_{1}}{C_{2}+C_{3}}$} \\
\hline & $\mathbf{C}_{1}$ & $C_{2}$ & $C_{2: 1}$ & $c_{3}$ & $C_{3: 1}$ & $n-C_{4}$ & $\mathrm{iC}_{4}$ & \\
\hline $\begin{array}{c}\text { Station } 14 \\
7-12 \\
40-45 \\
80-85 \\
95-100\end{array}$ & $\begin{array}{r}10,700 \\
13,800 \\
8,200 \\
5,700\end{array}$ & $\begin{array}{l}51 \\
56 \\
90 \\
73\end{array}$ & $\begin{array}{l}34 \\
46 \\
52 \\
54\end{array}$ & $\begin{array}{l}27 \\
31 \\
43 \\
41\end{array}$ & $\begin{array}{l}10 \\
15 \\
31 \\
24\end{array}$ & $\begin{array}{l}11 \\
\text { tr } \\
\text { tr } \\
\text { tr }\end{array}$ & $\begin{array}{l}11 \\
\operatorname{tr} \\
\operatorname{tr} \\
\mathrm{tr}\end{array}$ & $\begin{array}{r}138 \\
158 \\
62 \\
51\end{array}$ \\
\hline $\begin{array}{c}\text { Station } 15 \\
0-10 \\
10-15 \\
70-75 \\
115-120 \\
135-139\end{array}$ & $\begin{array}{r}9,900 \\
50,300 \\
28,800 \\
31,700 \\
35,500\end{array}$ & $\begin{array}{r}53 \\
33 \\
38 \\
70 \\
114\end{array}$ & $\begin{array}{r}166 \\
34 \\
28 \\
50 \\
53\end{array}$ & $\begin{array}{r}70 \\
22 \\
18 \\
43 \\
164\end{array}$ & $\begin{array}{r}72 \\
19 \\
9 \\
24 \\
22\end{array}$ & $\begin{array}{r}26 \\
10 \\
- \\
21 \\
38\end{array}$ & $\begin{array}{l}9 \\
10 \\
- \\
10 \\
19\end{array}$ & $\begin{array}{r}81 \\
928 \\
514 \\
279 \\
128\end{array}$ \\
\hline $\begin{array}{l}\text { Station } 16 \\
0-10 \\
10-15 \\
50-55 \\
90-95 \\
130-135 \\
152-157\end{array}$ & $\begin{array}{r}8,600 \\
5,100 \\
7,800 \\
9,300 \\
12,000 \\
14,600\end{array}$ & $\begin{array}{l}21 . \\
38 \\
27 \\
27 \\
60 \\
60\end{array}$ & $\begin{array}{l}31 \\
34 \\
28 \\
39 \\
67 \\
62\end{array}$ & $\begin{array}{l}26 \\
22 \\
18 \\
18 \\
40 \\
54\end{array}$ & $\begin{array}{r}15 \\
9 \\
9 \\
9 \\
24 \\
24\end{array}$ & $\begin{array}{l}- \\
- \\
- \\
10 \\
-\end{array}$ & $\begin{array}{l}- \\
- \\
- \\
- \\
-\end{array}$ & $\begin{array}{r}183 \\
86 \\
175 \\
205 \\
121 \\
128\end{array}$ \\
\hline $\begin{array}{l}\text { Station } 17 \\
0-10 \\
10-18 \\
60-69 \\
100-109 \\
145-159 \\
160-164\end{array}$ & $\begin{array}{r}3,900 \\
101,000 \\
99,000 \\
113,000 \\
6,700 \\
18,000\end{array}$ & $\begin{array}{r}55 \\
857 \\
8626 \\
6600 \\
770 \\
2005\end{array}$ & $\begin{array}{r}48 \\
27 \\
24 \\
- \\
44 \\
45\end{array}$ & $\begin{array}{r}34 \\
21 \\
24 \\
64 \\
313 \\
620\end{array}$ & $\begin{array}{r}22 \\
8 \\
\cdot \quad 7 \\
14 \\
14 \\
22\end{array}$ & $\begin{array}{c}8 \\
12 \\
\text { tr } \\
28 \\
187 \\
231\end{array}$ & $\begin{array}{r}- \\
8 \\
946 \\
982 \\
286 \\
433\end{array}$ & $\begin{array}{r}44 \\
115 \\
11 \\
17 \\
6 \\
7\end{array}$ \\
\hline $\begin{array}{c}\text { Station } 18 \\
0-10\end{array}$ & 0.74 & 26 & 43 & 17 & 11 & - & 16 & 17 \\
\hline
\end{tabular}


defined diagenetic processes in siliceous rocks (Hein et al., 1978). Since the diagenesis occurs at temperatures between 35 to $50^{\circ} \mathrm{C}$ and horizon $\mathrm{D}$ can be traced at an approximate depth of $1,200 \mathrm{~m}$, the geothermal gradient should be about 2.9 to $4.2^{\circ} \mathrm{C} / 100 \mathrm{~m}$.

Norton Basin is a young extensional basin where rifting ceased less than 60 m.y. ago. Theoretical findings suggest that considerable changes of heat flow had been occurring during the geologic evolution of this type of basin (Sclater and Christie, 1980; Royden et al., 1980). During the active extensional stage, the crust is thinned and the hot mantle is closer to the Earth's surface, causing increased heat flow. The major rifting stage is typically followed by fault controlled subsidence, and heat flow decreases gradually to the average continental values. According to Sclater and Christie (1980) and Royden et al. (1980) the maximum heat flow in the extensional basins occurs by the end of the rifting stage. These findings have been confirmed in many other extensional basins at various evolutionary stages (Fisher, 1982).

In view of the data presented above, it is reasonable to adopt an average geothermal gradient of $4.1^{\circ} \mathrm{C} / 100 \mathrm{~m}$ for the Norton Basin area.

\section{Structural Setting of the Aleutian Trench}

The Aleutian Trench system is one of at least six major convergent margins recognized on the Earth. Since the plate tectonic theory is generally accepted and utilized, numerous attempts have been made to find major tectonic fractures in the region required by the theory. These attempts, in essence, have constituted tests of the plate-tectonic theory. The Intensity of the subduction and accretionary processes seems to be differentiated along the Aleutian Trench. Already the geomorphology of the outer ridge areas shows significant differences (Figure 1) between the eastern, central and western sections of the Aleutian outer ridge. While the eastern and western parts of the outer ridge represent slopes relatively uniformly dipping toward the trench, the central section of the Aleutian outer ridge is wider and contains a terrace between the edge of the shelf and trench area. Probably the most (and still) controversial question pertaining to the position of the Benioff zone (Grow, 1973) is the general lack of compressional features in reflection seismic profiles from the areas adjacent to the Aleutian Trench. In recent years steady improvement of seismic processing has made it possible to distinguish new seismic boundaries within the Aleutian Trench system.

\section{Central Aleutian Trench}

A characteristic geomorphological feature of the central Aleutian Trench system is the ponded terrace (Seely, 1978) between the outer edge of the shelf and the lower slope and trench. During the summer of 1970, reflection seismic profiles, a sonobuoy refraction profile, near-bottom geophysical data, and bottom sediment samples were obtained by Scripps Institute of Oceanography (from the ships $R / V$ Melville and $R / V$ Washington). Also during the 
SEAMAP project, the U.S. Coast and Geodetic Survey obtained extensive bathymetric, magnetic and gravity coverage over the Aleutian Trench between $160^{\circ} \mathrm{W}$ and $180^{\circ} \mathrm{W}$ (Erickson and Grim, 1969; Malakoff and Erickson, 1969). Five reflection profiles extending $600 \mathrm{~km}$ south of the Aleutian Trench have also been presented by Hayes and Ewing (1970).

Although the quality of all these reflection records is not sufficient for discussion of the trench sediment and slopes, several interesting features have been interpreted. Selsmic reflection profiles from the trench area (Hayes and Ewing, 1970) show undeformed trench turbidites which terminate abruptly against the terrace edge. If the plate tectonic model is correct, the absence of folded sediments can be explained by the inability of low-strength sediments to propagate a fold (or thrust) for more than 2-3 km from the inner slope. In areas close to the inner slopes, the sediment deformations are extremely difficult to detect by surface reflection prdfiles as they are masked by side echoes. Probably the most surprising feature of the terrace profiles is the undeformed character of the thick terrace sediments. The Atka is the most prominent sedimentary basin in the central Aleutian forearc subregion. The sediments which are $5,000-8,000 \mathrm{~m}$ thick in axis of the basin show only slight arching in the south and downwarping in the north. In the northern part of the terrace the thickness of sediment is at least $2,000 \mathrm{~m}$. The southern part of the Aleutian terrace consists of an uplifted anticlinal arch known as the Howley Ridge.

While no obvious compressional features were found in the central inner Aleutian Trench, a number of studies have suggested that tensional faulting is the predominant type of deformation observed in this area (von Huene and Shor, 1969; Lister, 1971). Grow (1983) pointed out that, although the evidence for compressive deformation on the north slope is insufficient and inferential, thrust faulting appears to be the initial type of deformation in the central Aleutian Trench.

\section{Eastern Aleutian Trench}

One of the most recent interpretations of the seismic data was published by von Huene et al. (1983), and Kvenvolden and von Huene (1985). Both groups of authors used records obtained with the seismic system aboard the U.S. Geological Survey (USGS) research vessel S.P. Lee during the field seasons of 1976, 1977, and 1981. The interpretation of these records showed that a large volume of sediment is being subducted in the eastern Aleutian Trench. Prior to entering the subduction zone, the thickness of sediment in the trench varies from a little more than $2,000 \mathrm{~m}$ (von Huene, 1972) to about $5,000 \mathrm{~m}$. Although the subduction zone of the eastern Aleutian Trench displays a variety of structural styles, the typical structural features are shown on Figures 39 and 40 . The trench fill consists of about $2,000 \mathrm{~m}$ thick turbidite and hemipelagic sediment that is 600,000 years old (DSDP Site 180). As the sediment passes into the subduction zone, the first deformation is marked by small proto-reverse faults which do not reach the surface. Two sections in vertical profiles can be noticed; the upper part is scraped of at the deformation front and accreted to the front of the margin, whereas the lower part is subducted. The depth of the boundary between the two parts varies and usually can be found above or below the base of the hemipelagic sediment 


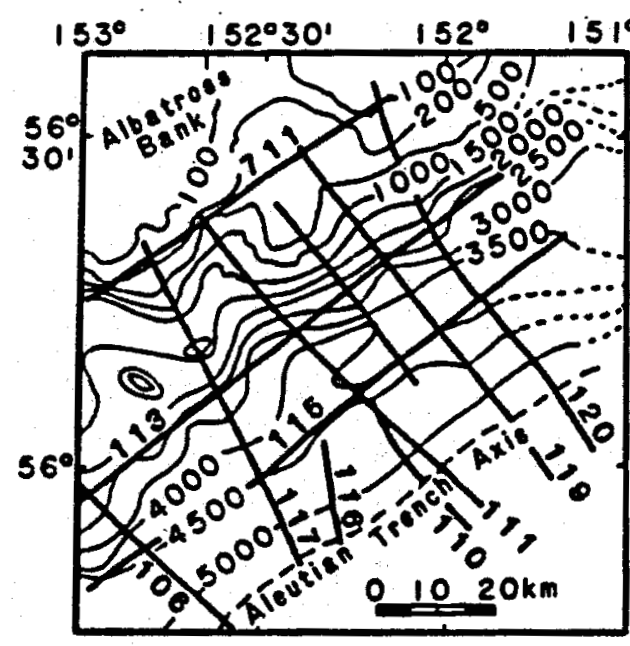

A
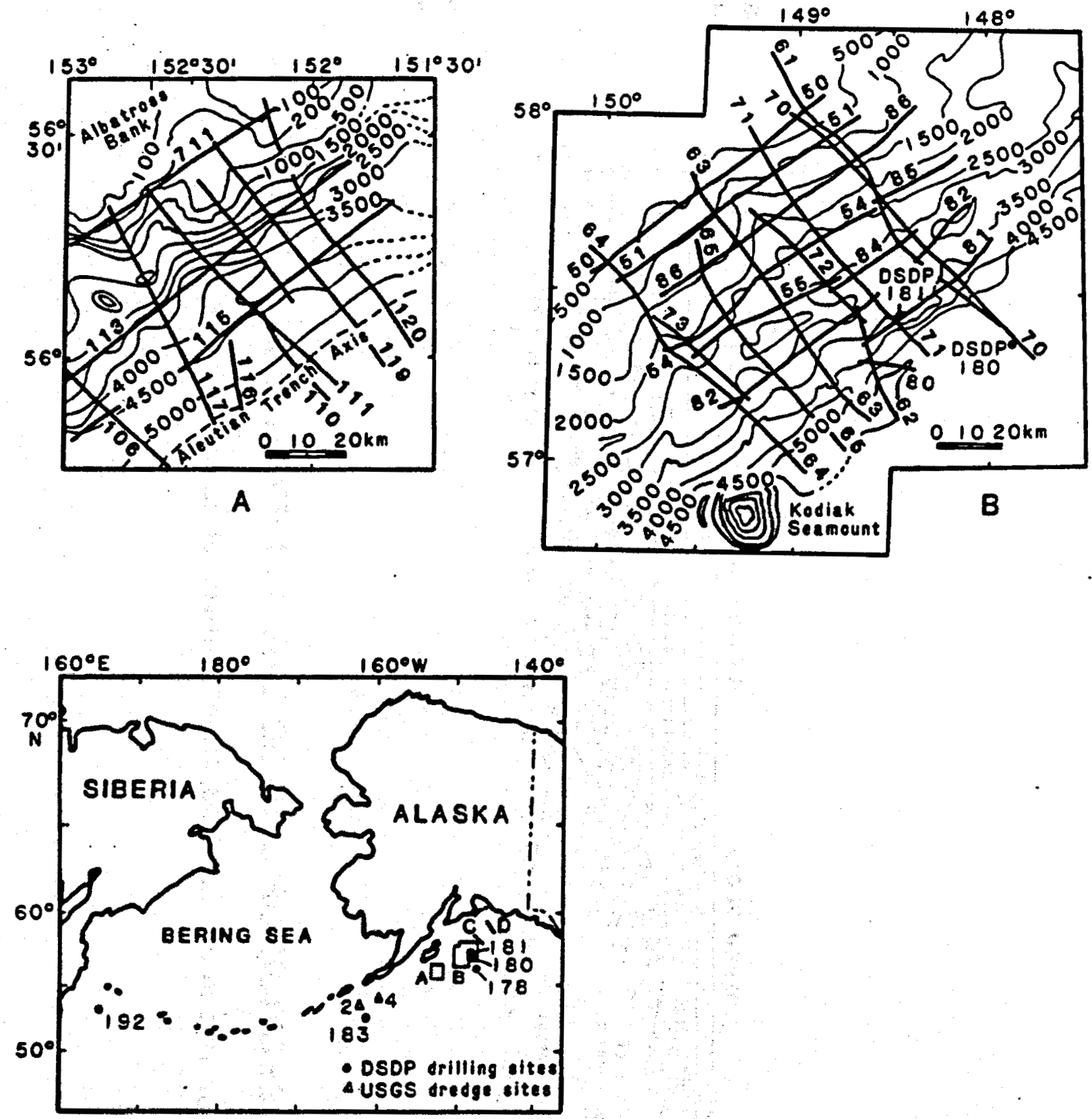

Figure 39. LOCATIONS OF SEISMIC-SURVEY GRIDS A AND B WITH POSITIONS OF MULTICHANNEL SEISMIC LINES.

LOCATIONS OF SINGLE SEISMIC LINES C AND D ARE ALSO SHOWN. IN ADDITION, DSDP SAMPLE SITES 178, 180, 181, 183, AND 192 (०) NWD USGS DREDGE SITES 2 AND 4 ( $(4)$ ARE INDICATED 


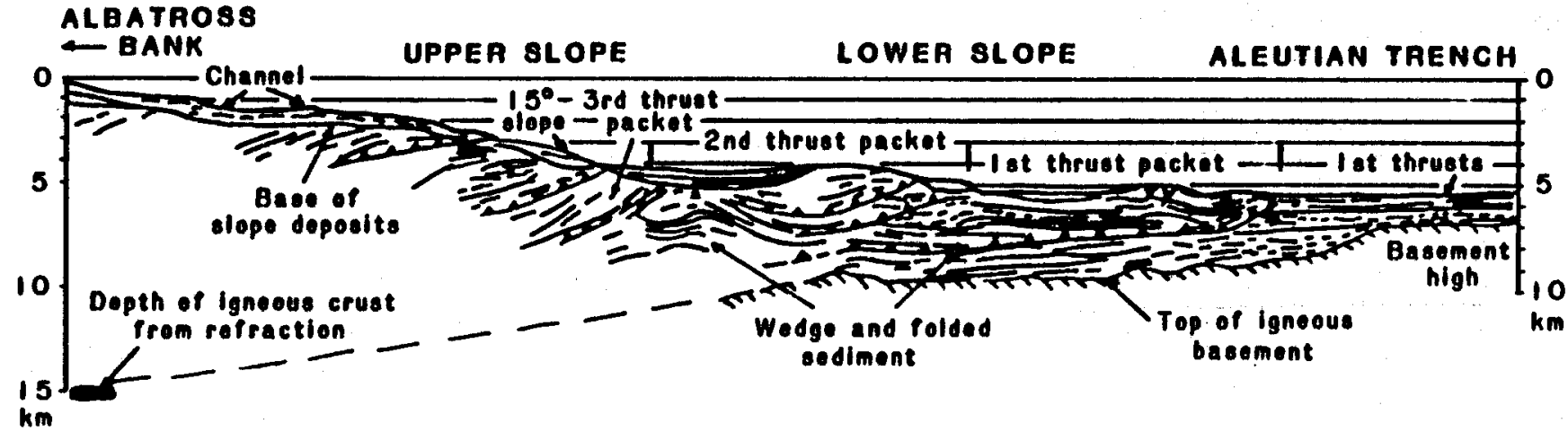

Figure 40. DEPTH SECTION OF SEISMIC LINE 111 FROM GRID A, FIG. 39

After von Huene et al., 1983, from Kvenvolden and von Huene, 1983 
filling the trench axis. In the record shown in Figure 40, the subducted sediment thins slightly landward. The slope of the trench steepens in the midslope area and its structure becomes almost monoclinal. The upper part of the midslope does not display features of horizontal compression. It shows, instead, characteristics of being uplifted as a rigid body. This change in tectonic regime was interpreted by von Huene (1979) as an indication of a transition from the zone of a weak, offscraped sediment with elevated pore fluid pressure at the front of the margin to a more rigid body.

Another two seismic records at lines C and D (Figure 41) show a very thick of fscraped section while there is no clear evidence on the presence of the subducted sediment. In both records the basement has not been imagined and therefore full interpretation of them cannot be made at the present time.

Contrary to line $C$, the nearby seismic record along nearby line $D$ (Figure 41) shows subduction of the complete sediment section (Plafker et al., 1982). The seismic records from both closely spaced lines seem to indicate the possible variability from total sediment subduction to total sediment of fscraping and its accretion to the margin.

\section{Atka Basin}

As the scientific debates over the structural features of the Aleutian forearc region continue, the lithostratigraphy of the rocks in these areas are still relatively poorly recognized. At the present time rare DSDP (Deep Sea Drilling Project) drilling sites and dredge sediment samples from the ocean bottom in the region are the sole source on lithostratigraphic information. In the situation where the structural position of the dredged samples of ten is questionable, the DSDP sites are of major importance.

Two DSDP wells have been drilled at Sites 186 and 187 in the of fshore area between the central Aleutian Islands and the Aleutian Trench. These sites are located on the southern flank of the Aleutian terrace within a major forearc structure in the Atka Basin (Figure 2). Thus, the latter basin is perhaps the best lithostratigraphically documented in the Aleutian forearc region. On the other hand, the lack of drilling data along the lower landward slope of the Aleutian Trench has resulted in the age of this structure within the accretionary prism being poorly constrained.

\section{Lithostratigraphy}

DSDP Site 186 (Figure 42). At this site the basement represented by the upper Miocene deformed sediments was penetrated at a depth of $926 \mathrm{~m}$. The sediment sequence consists mostly of diatomaceous silty clay ranging in age from late Pleistocene through early Pliocene. The olive-gray diatomaceous silty clay typically contains $30-40$ percent diatoms. Diatom ooze constitutes 50-75 percent of the sediment near the top of the profile. At depths 448 and $509 \mathrm{~m}$ light ollve-gray diatomaceous calcite silt layers were identified. Much of the diatomaceous silty clay in this interval is carbonate bearing. The carbonate part of sediment probably represents altered nannofossil plates. Throughout the sedimentary sequence the terrigenous silt/clay 
LINE 13

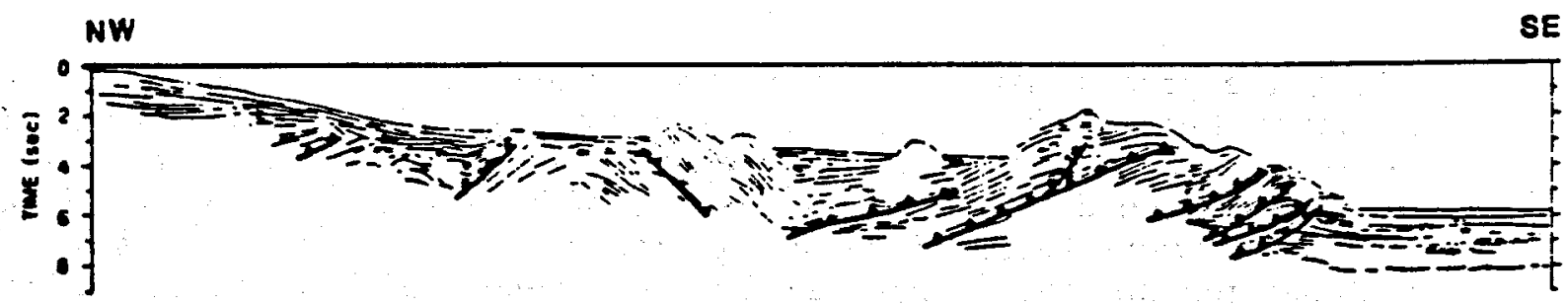

LINE D

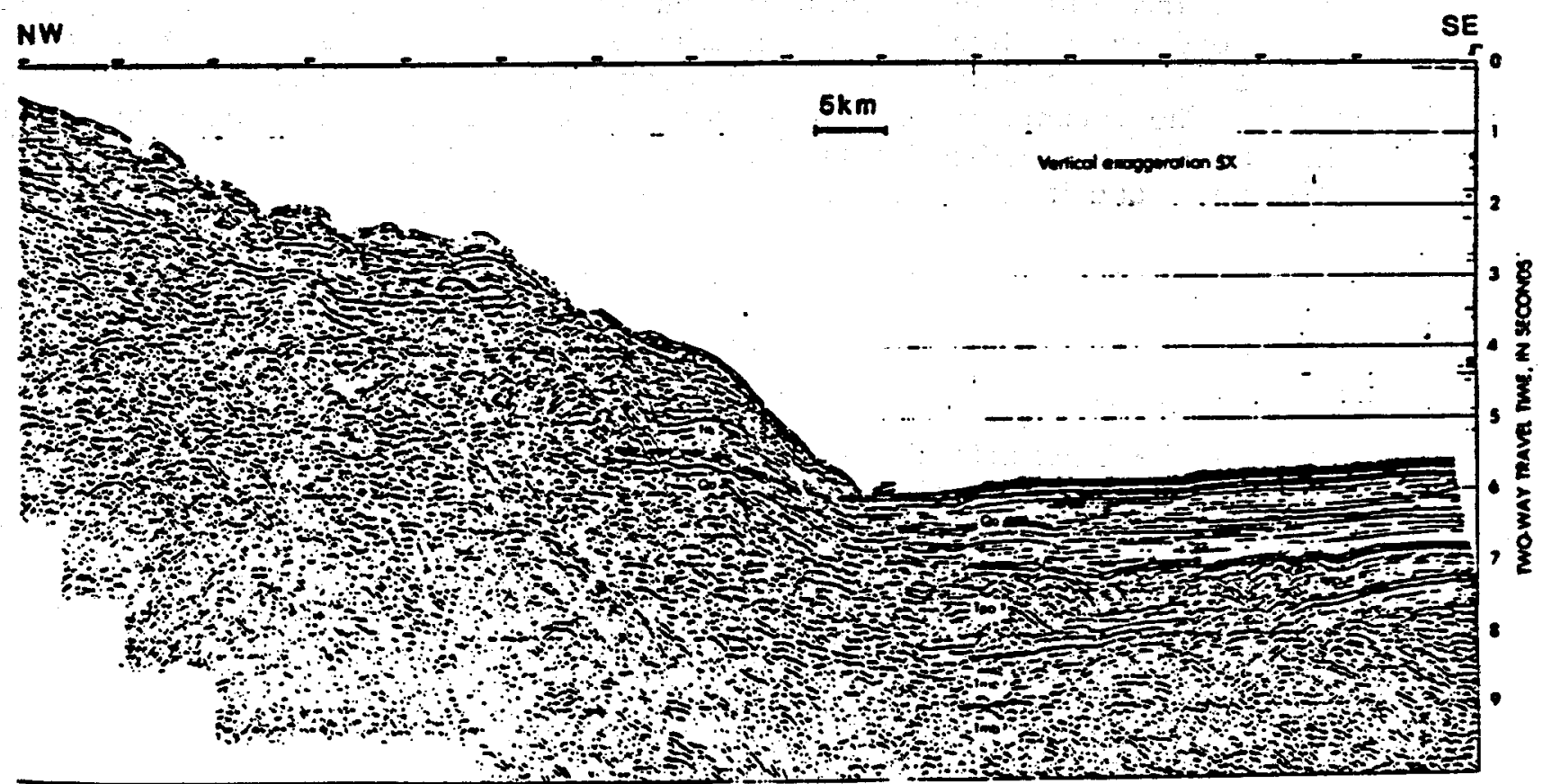

SEE FIGURE 39 FOR LOCATION

Figure 41. TIME SECTIONS OF SEISMIC LINE 13 (WHICH IS THE SAME AS LINE C) AND SEISMIC LINE D

\author{
After Kvenvolden and von Huene, 1983
}


SITE 186

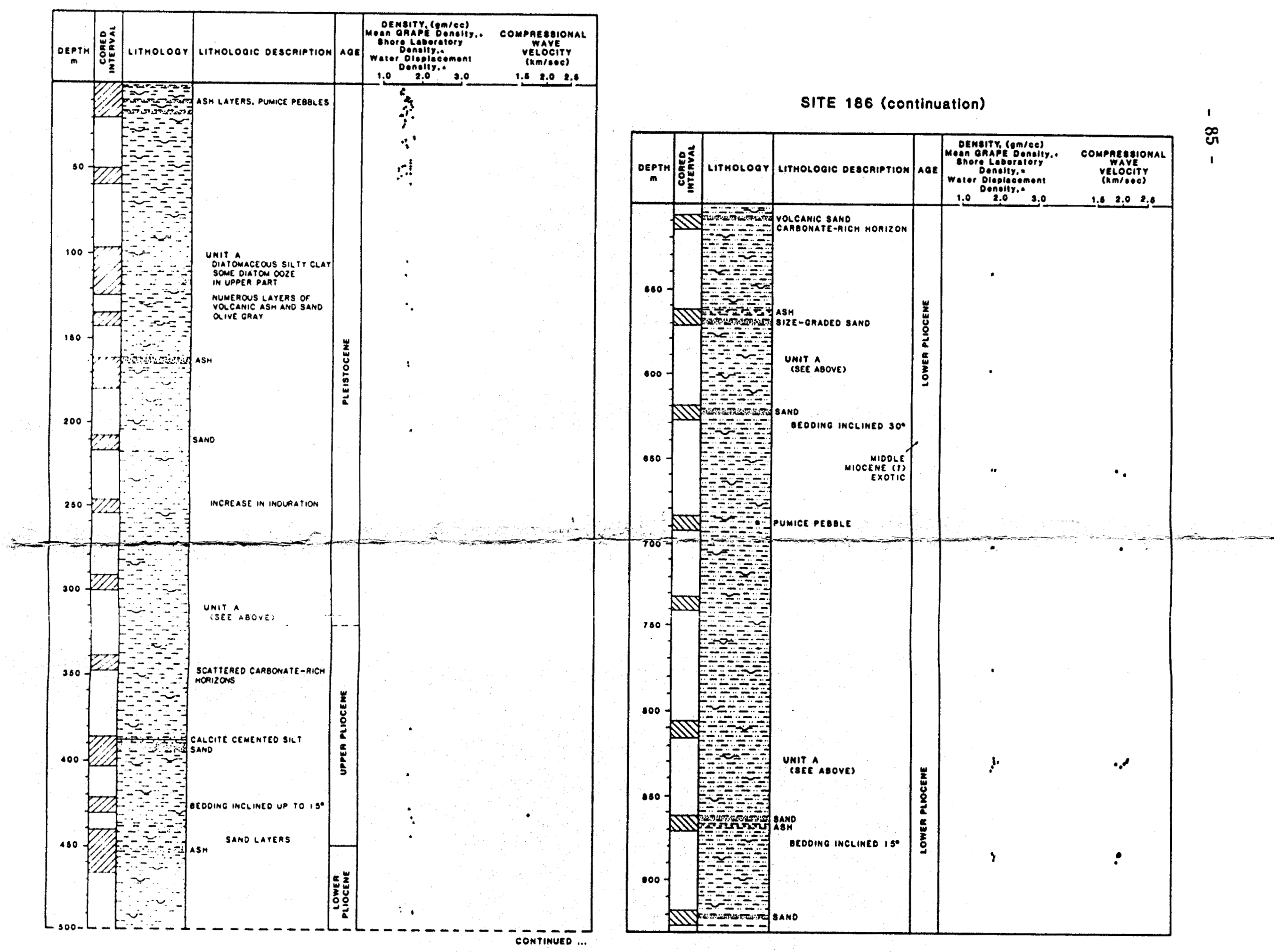

Figure 42. LITHOSTRATIGRAPHY AND PHYSICAL PROPERTIES OF SEDIMENTS AT DSDP LEG 19, SITE 186 
ratio is usually 1:2. Other rock components found in the lithological profile of the DSDP Site 186 are volcanic ash, silt, and sand. Although beds of the volcanic ash sporadically occur throughout the entire profile they are particularly abundant in the upper $20 \mathrm{~m}$ of the profile. The ashes are light gray and brownish-gray. Vitric components of the ashes are colorless to light brown and unaltered. A distinctive pumice bearing ash layer was detected in the interval of 161 to $165 \mathrm{~m}$. Several beds of brownish-gray to very dark gray silt and sand have been distinguished at depth intervals of 0 to $20 \mathrm{~m}, 100$ to $220 \mathrm{~m}$, and 850 to $926 \mathrm{~m}$. The thickness of the sand layers is up to $4.5 \mathrm{~m}$ whereas the sand is usually medium to coarse grained. It represents concentrations of disaggregated volcanic rocks, mainly of andesite and basalt. Many of the sand layers display parallel laminations, size grading, and convolute laminations, particularly within thicker beds. Presence of foraminifera in sand layers appears to be indicative of outer sublittoral or perhaps upper bathyal depth zones (Creager et al., 1973). Most of the sand-size grains are angular to subrounded and therefore the sand layers are mostly texturally immature (Stewart, 1979). The available grain-size data (Bode, 1973) show that clay content in the sand beds is mostly less than 10 percent. Accordingly with Dott's (1964) classification, these sands should be termed "arenites" in contrast to "wackes" in which more clay matrix is present.

The degree of induration of sediments in the Atka Basin increases sharply at about $230 \mathrm{~m}$ with an increasing trend downhole (Creager et al., 1973). At the base of the section the silty clay becomes mudstone and some of the sand layers are lithified.

A sequence of diagenetic changes in fine grained diatomaceous sediment at many DSDP sites in the North Pacific and Bering Sea has been discussed by Hein et al. (1976). They noted that corrosion and dissolution of diatoms constitute major factors altering sediment originally rich in diatomaceous particles to mudstone with a diatom and clay matrix. At most of the North Pacific drilling sites Hein et al. (1976) were able to find pyrite, zeolites, clays, and other diagenetic minerals in abundance. A similar spectrum of alteration products has been found in the coarser-grained sand layers at DSDP Site 186. These alteration products include rare carbonate cement and authigenic clay minerals. The problem of the diagenetic alterations will be further addressed in a chapter with the discussion of the Bottom Simulating Reflectors (BSRs).

An approximately $60-\mathrm{m}$ thick section of middle Miocene silty clay enclosed from below and above by silty clay of Pliocene age was found at a depth interval of 622 to $680 \mathrm{~m}$ at DSDP Site 186. The contact between the top of the Miocene sediments and those of Pliocene age is marked by a sharp change of color from grayish to gray. The paleontological data from the Miocene unit suggests the allochtonous origin of these sediments.

DSDP Site 187 is located 2.3 miles southeast of Site 186 (Figure 43) in the area of the outer ridge of Atka Basin. The sediments at this site were penetrated to a depth of $370 \mathrm{~m}$ whereas the acoustic basement composed of late Miocene deformed sediments was encountered at $160 \mathrm{~m}$. The sediment sequence of Site 187 is represented by diatomaceous silty clay similar to that recovered at Site 186. 
SITE 187

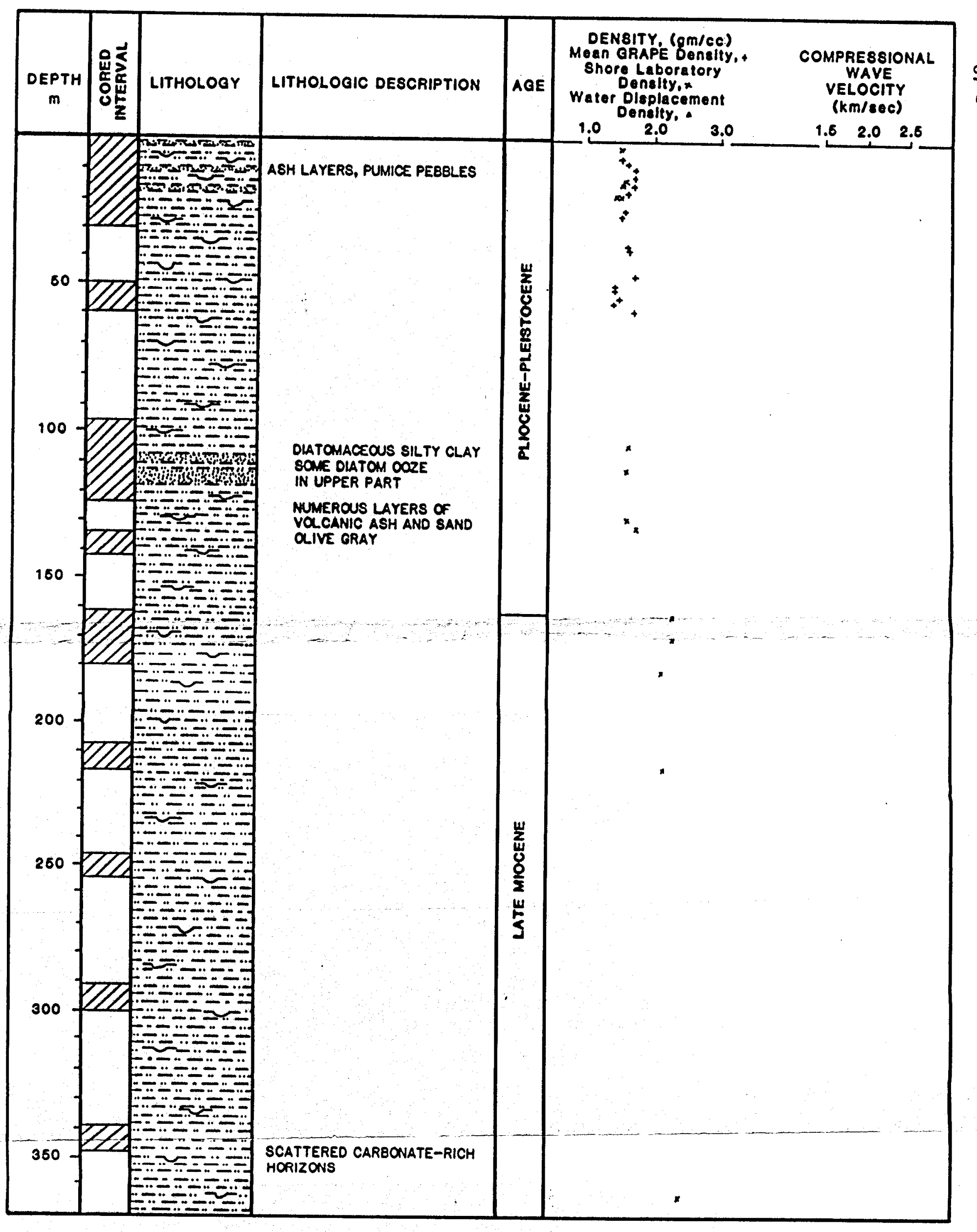

Figure 43. LITHOSTRATIGRAPHY AND PHYSICAL PROPERTIES OF SEDIMENTS AT DSDP LEG 19, SITE 187

After Scholl et al., 1971 


\section{Rate of Sedimentation}

Early geologic studies of the Aleutian Ridge revealed a major hiatus separating rocks of early and late Cenozoic age. Gates et al. (1956) placed this unconformity in mid-Tertiary time. The major uplift of the Aleutian Ridge in middle and late Miocene initiated a period of extensive erosion prior to the outbreak of volcanism which formed the ridge's chain of volcanoes about 2 m.y. ago (Bingham and Stone, 1971). Assuming that the basement rocks in the Atka Basin represent a Pliocene/late Miocene boundary 5 m.y. old (Watkins, 1976), the accumulation rate of silty clays in the area of the Site 186 uncorrected for compaction was about $190 \mathrm{~m} / \mathrm{m} . \mathrm{y}$. This value corrected for compaction could probably increase to about $300 \mathrm{~m} / \mathrm{m} . \mathrm{y}$. (Lee, 1973). During the Pliocene period the rate of sedimentation varied from $200 \mathrm{~m} / \mathrm{m} . \mathrm{y}$. (uncorrected) in early Pliocene to $130 \mathrm{~m} / \mathrm{m} . \mathrm{y}$. (uncorrected) in late Pliocene. In Pleistocene the accumulation rate increased slightly to about $180 \mathrm{~m} / \mathrm{m} . \mathrm{y}$ (Figure 44). Scholl and Creager (1973) suggested that the high rates of sedimentation were caused by more subaerially exposed Aleutian Ridge in late Miocene to Pleistocene time.

\section{Organic Matter}

The presence of organic matter is considered a critical factor in the process of hydrocarbon generation. The process itself has been broadly discussed in numerous papers (e.g. Claypool and Kaplan, 1974). Many authors have stated that a minimum of 0.5 percent organic carbon is needed to sustain biogenic methanogenesis (Hunt, 1976). Although present distribution of the organic carbon in vertical profile does not necessarily reflect the original organic carbon content in a strata it shows, quantitatively, the intervals in which rocks could be hosts to the processes of methanogenesis. The distribution of organic carbon in the profile of DSDP Site 186 in the Atka Basin is shown in Table 8.

Analytical data of the organic carbon coincides well with the previously described lithology at the same drilling site. Approximately 30 percent of the analyzed samples display the marginal 0.5 percent organic carbon necessary for sustaining methanogenesis. Its maximum value of 0.6 percent was found in only 4 samples. Based on the content of organic carbon, the sediments in at least some sections of DSDP Site 186's profile occur in sufficient quantities to be considered potential source rocks for hydrocarbon generation.

\section{Hydrocarbon Gas In Sediment}

Geochemical analyses of gas extracted from cores at DSDP Site 186 present unique values for understanding the hydrocarbons' origin in the Atka Basin. The gas samples were collected by puncturing the core liner and removing the gas into an evacuated glass container. The procedure, however, does not provide the quantitative information on gas content in sediment under in situ conditions. The gas samples were specifically analyzed for methane, ethane, and carbon dioxide. Oxygen and nitrogen were detected on 


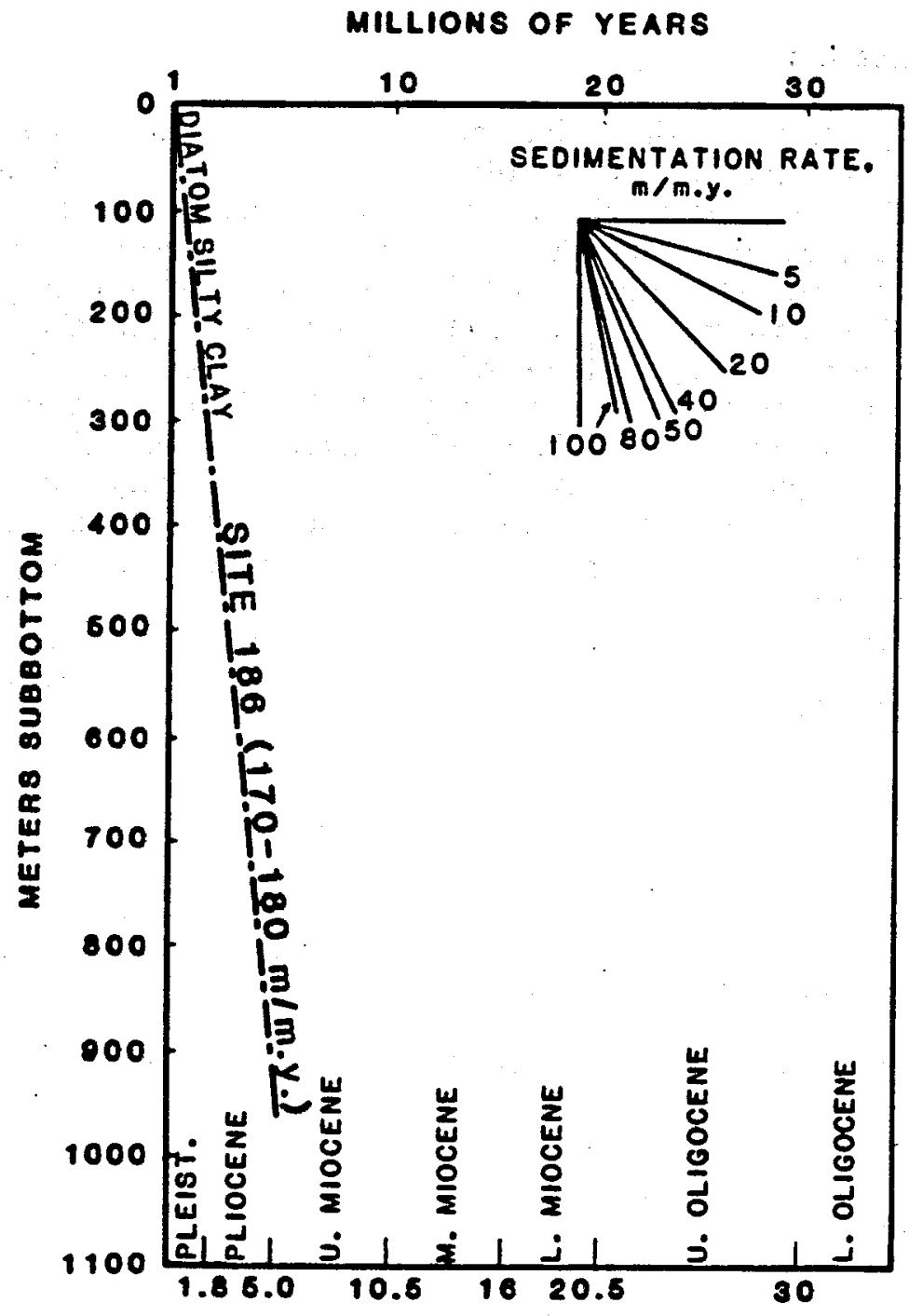

Figure 44. DIAGRAM OF UNCORRECTED RATE OF SEDIMENTATION AT DSDP SITE 186 After Scholl and Creager, 1971 
TABLE 8.

ORGANIC CARBON CONTENT AT DSDP SITE 186 After Claypool et al., 1971

\begin{tabular}{|c|c|c|}
\hline $\begin{array}{c}\text { Core, Section } \\
\text { Top of } \\
\mathrm{cm}\end{array}$ & $\begin{array}{l}\text { Depth } \\
\text { in Hole } \\
\text { m }\end{array}$ & $\begin{array}{c}\text { Organic } \\
\text { Carbon } \\
\%\end{array}$ \\
\hline $\begin{array}{c}7-2(80.0) \\
7-2(100.0) \\
8-5(76.0) \\
9-1(86.0) \\
9-6(96.0) \\
10-2(71.0) \\
11-2(76.0) \\
11-4(56.0) \\
13-1(131.0) \\
17-3(7.0) \\
17-3(101.0) \\
18-2(45.0) \\
18-3(85.0) \\
19-2(68.0) \\
20-4(24.0) \\
21-3(31.0) \\
22-2(42.0) \\
22-3(45.0) \\
22-3(82.0) \\
22-3(104.0) \\
22-3(142.0) \\
22-7(0) \\
23-2(57.0) \\
23-3(110.0) \\
24-3(81.0) \\
25-1(51.0) \\
25-1(140.0) \\
26-2(34.0) \\
27-3(30.0) \\
28-3(92.0) \\
\end{array}$ & $\begin{array}{l}116.30 \\
116.30 \\
139.76 \\
161.86 \\
169.46 \\
172.21 \\
209.25 \\
212.06 \\
292.31 \\
425.07 \\
426.01 \\
445.95 \\
447.85 \\
451.18 \\
462.74 \\
509.31 \\
563.92 \\
565.45 \\
565.82 \\
566.04 \\
566.42 \\
571.00 \\
620-07 \\
622.10 \\
686.81 \\
731.51 \\
732.40 \\
806.84 \\
864.30 \\
920.92\end{array}$ & $\begin{array}{l}0.4 \\
0.1 \\
0.5 \\
0.1 \\
0.6 \\
0.5 \\
0.1 \\
0.3 \\
0.4 \\
0.5 \\
0.3 \\
0.4 \\
0.3 \\
0.5 \\
0.6 \\
0.3 \\
0.5 \\
0.3 \\
0.1 \\
0.1 \\
0.1 \\
0.1 \\
0.5 \\
0.6 \\
0.4 \\
0.6 \\
0.4 \\
0.4 \\
0.4 \\
0.3\end{array}$ \\
\hline
\end{tabular}

the chromatograms jointly as one undifferentiated peak. The values obtained for each component of gas were corrected for atmospheric contamination. The relative proportions of the three major analyzed gases $\left(\mathrm{CH}_{4}, \mathrm{C}_{2} \mathrm{H}_{6}, \mathrm{CO}_{2}\right)$ were computed using the following formulas: 
vol. $\% \mathrm{CH}_{4}=\frac{1}{\left(\mathrm{CO}_{2} / \mathrm{CH}_{4}+\left(\mathrm{C}_{2} \mathrm{H}_{6} / \mathrm{CH}_{4}\right)+1\right.} \times 100$
vòl. $\% \mathrm{C}_{2} \mathrm{H}_{6}=\frac{\mathrm{C}_{2} \mathrm{H}_{6} / \mathrm{CH}_{4}}{\left(\mathrm{CO}_{2} / \mathrm{CH}_{4}\right)+\left(\mathrm{C}_{2} \mathrm{H}_{6} / \mathrm{CH}_{4}\right)+1} \times 100$
vol. $\% \mathrm{CO}_{2}=\frac{\mathrm{CO}_{2} / \mathrm{CH}_{4}}{\left(\mathrm{CO}_{2} / \mathrm{CH}_{4}\right)+\left(\mathrm{C}_{2} \mathrm{H}_{6} / \mathrm{CH}_{4}\right)+1} \times 100$

The absolute precision of measurements, performed in the described manner, was \pm 0.1 percent for methane, \pm 0.001 percent for ethane and carbon dioxide.

The $\delta^{13} \mathrm{C}$ was measured and presented in the conventional way described by Kaplan, Smith and Ruth (1970) using delta notation relative to the PDB standards.

Some results of the gas from sediment collected at DSDP Site 186 are shown in Tables 9 and 10:

TABLE 9.

\section{CHEMICAL AND ISOTOPIC COMPOSITION OF GAS SAMPLES \\ IN SEDIMENT AT DSDP SITE 186 \\ After Claypool et al., 1971}

\begin{tabular}{|c|c|c|c|c|c|}
\hline \multirow[b]{2}{*}{ Sample } & \multirow{2}{*}{$\begin{array}{l}\text { Depth Below } \\
\text { Sea Floor } \\
\text { m }\end{array}$} & \multicolumn{3}{|c|}{ Component, Volume $\%$} & \multirow{2}{*}{$\frac{\delta^{13} \mathrm{C} \text { (per mil) }}{\mathrm{CH}_{4}}$} \\
\hline & & $\mathrm{CH}_{4}$ & $\mathrm{C}_{2} \mathrm{H}_{6}$ & $\mathrm{CO}_{2}$ & \\
\hline $\begin{array}{r}186-3 \\
6 \\
9 \\
19 \\
28\end{array}$ & $\begin{array}{r}20 \\
110 \\
167 \\
450 \\
920\end{array}$ & $\begin{array}{l}99.9 \\
99.5 \\
99.4 \\
99.7 \\
99.9\end{array}$ & $\begin{array}{l}\text { n.d } \\
\text { trace } \\
\text { n.d. } \\
\text { trace } \\
0.009\end{array}$ & $\begin{array}{l}0.121 \\
0.466 \\
0.553 \\
0.263 \\
0.110\end{array}$ & $\begin{array}{l}-78.8 \\
-68.4 \\
-71.6 \\
-71.3 \\
-62.7\end{array}$ \\
\hline
\end{tabular}


TABLE 10.

ORGANIC CARBON AND GAS CONTENT AT DSDP SITE 186 After McIver, 1971

\begin{tabular}{llrlrrr}
\hline Core & Section & $\begin{array}{c}\text { Depth } \\
\text { Below Sea } \\
\text { Floor, } \mathbf{m}\end{array}$ & $\begin{array}{c}\text { Age } \\
\text { Organic } \\
\text { Carbon } \\
\%\end{array}$ & $\begin{array}{c}\text { Hydrocarbon } \\
\text { Gas } \\
\text { ppmv }\end{array}$ & $\begin{array}{c}\text { Methane } \\
\text { in Gas } \\
\%\end{array}$ \\
\hline 3 & $2(0 \mathrm{~cm})$ & 1 & Pleisto. & 0.53 & 112,900 & 100 \\
3 & $3(150 \mathrm{~cm})$ & 3 & Pleisto. & 0.46 & 17,100 & 100 \\
3 & $5(0 \mathrm{~cm})$ & 6 & Pleisto. & 0.89 & 40,800 & 100 \\
3 & $5(150 \mathrm{~cm})$ & 6 & Pleisto. & 0.68 & 3,400 & 100 \\
3 & $6(150 \mathrm{~cm})-1$ & 15 & Pleisto. & 0.74 & 27,600 & 100 \\
3 & $6(150 \mathrm{~cm})-2$ & 15 & Pleisto. & 0.62 & 216,700 & 100 \\
4 & $5(150 \mathrm{~cm})$ & 55 & Pleisto. & 0.50 & 49,900 & 100 \\
6 & $1(150 \mathrm{~cm})$ & 107 & Pleisto. & 0.36 & 26,800 & 100 \\
9 & $7(10 \mathrm{wer})$ & 167 & Pleisto. & 0.56 & 28,900 & 100 \\
20 & $5(0 \mathrm{~cm})$ & 465 & Pleisto. & 0.40 & 27,800 & 100 \\
\hline
\end{tabular}

Carbon isotopic composition of a gas and its molecular composition are currently used as indicators in establishing biogenic or thermogenic provenance (Fuex, 1977; Waples, 1981). Based on the fact that thermal degradation of organic matter does not produce the same enrichment in ${ }^{12} \mathrm{C}$ as biologically produced methane, different values of $\delta^{1} \mathrm{C}$, have been obtained for thermogenic and biogenic $\mathrm{CH}_{4}$. The isotopic value, $\delta^{13} \mathrm{C}$ is defined as (values are reported in "per mil.", abbreviated " $/ 00 "$ ):

$$
\delta^{13} \mathrm{C}=\left(\frac{{ }^{13} \mathrm{C} /{ }^{12} \mathrm{C} \text { sample }}{{ }^{13} \mathrm{C} /{ }^{12} \mathrm{C} \text { PDB standard }}-1\right) \times 1,000
$$

Biogenic methane is usually characterized by $\delta^{13} \mathrm{C}$ values below the average -55 to $-65 \%$ and is associated with a very low content of ethane (<0.1 percent). Claypool et al. (1971) have indicated that thermal degradation of organic matter produces low molecular-weight organic compounds, primarily methane, ethane, and (in smaller amounts) higher hydrocarbons. According to these authors the presence of small quantities of ethane in the gas phase, where the ratio of $\mathrm{C}_{2} \mathrm{H}_{6} / \mathrm{CH}_{4}$ reaches $10^{-4}$ to $10^{-6}$, indicates an admixture of small quantities of thermogenic products with biogenic methane. A ratio of $\mathrm{C}_{2} \mathrm{H}_{6} / \mathrm{CH}_{4}$ higher than $10^{-6}$ probably indicates thermally produced hydrocarbons.

Data of chemical isotopic composition of gas samples from sediments of DSDP Site 186 (Tables 9 and 10; Figure 45) strongly suggest the biogenic origin of the analyzed hydrocarbons. The values of methane and ethane content as isotopic values of $\delta^{13} \mathrm{C}$ are well within generally accepted ranges 


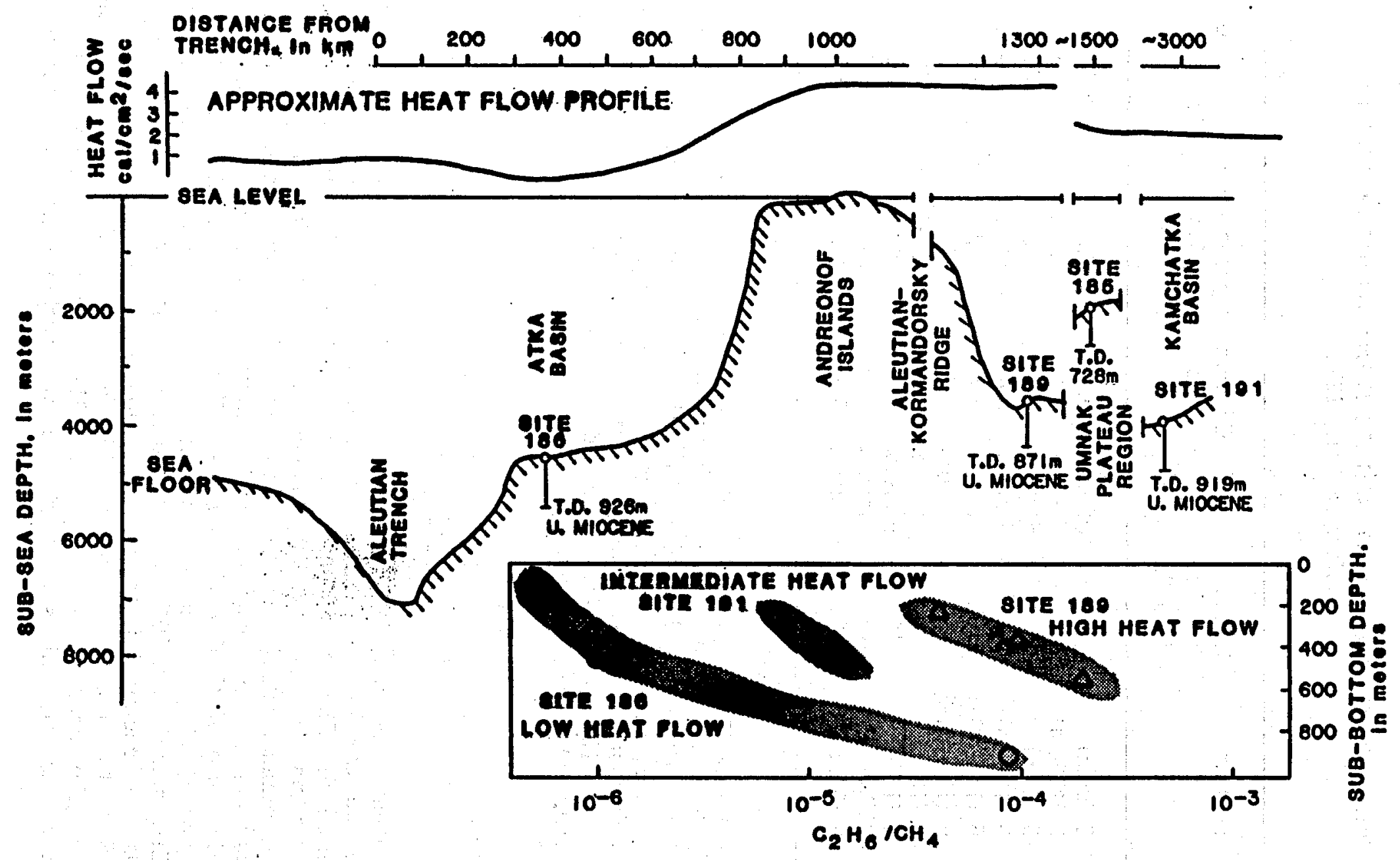

Figure 45. VARIATION.W ETHANE/METHANE RATIOS WITH DEPTH AND WITH DIFFERENT THERMAL REGIMES ACROSS THE ALEUTIAN-ARC SYSTEM

After Claypool ot al., 1971 
for biogenic gases. In the case of the Atka Basin, a high rate of sedimentation created an additionally favorable anoxic environment for methanogenesis. The favorable conditions for hydrocarbon generation in the Atka Basin have been confirmed by observation of relatively high gas quantities in the profile of DSDP Site 186. Creager et al. (1973) reported intensive gas bubbles in several sand layers of the upper $200 \mathrm{~m}$ of sediments. According to McIver (1973), the gassiest sediment sample during Leg 19 was encountered at about $30 \mathrm{~m}$ subbottom depth at Site 186. Although the 216,700 ppmv (parts per million by volume) of methane in this sample is only about one third of the gas needed to saturate the interstitial water under local conditions, preservation of this gas in sediment is astonishing considering the ordinary sampling procedures. A duplicate sample from the same depth interval yielded only 49,900 ppmv of methane.

\section{Geothermal Gradient}

Numerous investigations of the heat flow in convergent margins revealed lower values of geothermal gradient in areas adjacent to the Aleutian Trench than in areas near a magmatic arc (McKenzie and Sclater, 1968; Anderson et al., 1978). This phenomenon was explained by the fact that isotherms in the upper plate of such margins are depressed because of subduction of cold lithosphere under the continental margin. Such a pattern in the heat flow distribution has been unequivocally proved in the area across the margin of Japan (Watanabe et al., 1977). The thermal profile across the Aleutian Trench-Arc system in the vicinity of the Atka Basin (Figure 45) presented by Claypool et al. (1973) fully conforms with the above described pattern. Heat flow values show extremely low values of 0.8 to $1.0 \mathrm{cal} / \mathrm{cm}^{2} / \mathrm{s}$. Although the geothermal gradient was not measured in the borehole of Site 186, the above quoted values of heat flow may well correspond to the geothermal gradient of 18 to $25^{\circ} \mathrm{C} / 1,000 \mathrm{~m}$. 


\section{Eastern Aleutian Trench-Arc System}

\section{Sedimentation and Lithostratigraphy}

The sedimentological processes in the eastern Aleutian Trench-Arc system are still in the midst of frequently controversial scientific debates. In recent years significant progress in this field has been made due to the strong efforts toward improvement of seismic data resolution and direct lithostratigraphic data obtained from DSDP Sites 178, 180, 181, 182, and 183 (Figure 46). The latter data constitute an invaluable source of material in a difficult task of reconciling the sedimentary data with of ten varying theories pertaining to the tectonic development of the region.

Sites 178-183 represent a cross-section of sedimentary sequences from contemporary areas of the abyssal plain (Site 178 and 183), Aleutian Trench (Site 180), and the area of lower and upper continental slope most likely representing the accretionary wedge (Sites 181 and 182).

Abyssal Plain. The lithology at Site 178 varies from deep-ocean pelagic sediments to thick glacial marine turbidites. Above approximately $640 \mathrm{~m}$ $(2,099 \mathrm{ft})$ subbottom depth, buried turbidity current channels are noticeable on seismic sections. The transition from predominantly pelagic to mainly turbidite sedimentation probably took place between early to middle Miocene: This period of time is represented by a deep sea sedimentary environment where terrigenous sediments were deposited. During Pliocene-Pleistocene time abundant glacial material was added to the sedimentary sequence of Site 178. The results of clay mineralogy studies well reflected changes of the sedimentary environments with periods of rapidly increased influx of terrigenous sediment about 4 m.y. ago (Hayes, 1973). Clays which constitute $90 \%$ of the samples of early Miocene were found to be reduced to $30 \%$ in samples from the middle Miocene strata. The increase of detrital material deposition is marked by an increased presence of terrigenous montmorillonite, chlorite, and mica in Pliocene age rock samples. Changes from the pelagic sedimentation to turbidites fits the picture of the sedimentation rate at Site 178 (Figure 47). A low rate of sedimentation usually corresponds to the pelagic sedimentation. Prior to Miocene the sedimentation rate at Site 178 was 3-9 m/m.y. During the following $18 \mathrm{~m} . \mathrm{y}$. (to early Pleistocene) the rate of sedimentation shows a significant increase to $105 \mathrm{~m} / \mathrm{m} . \mathrm{y}$. During the late Pleistocene the sediments in vicinity of Site 178 were deposited at rates ranging from 215 to $135 \mathrm{~m} / \mathrm{m} . y$. Increased turbidite sedimentation approximately 13 to 14 m.y. ago was probably related to plate motion as Site 178 was gradually moved closer to Kodiak Island and actively eroded the mountains around the Gulf of Alaska. Detailed studies of the sediments in 


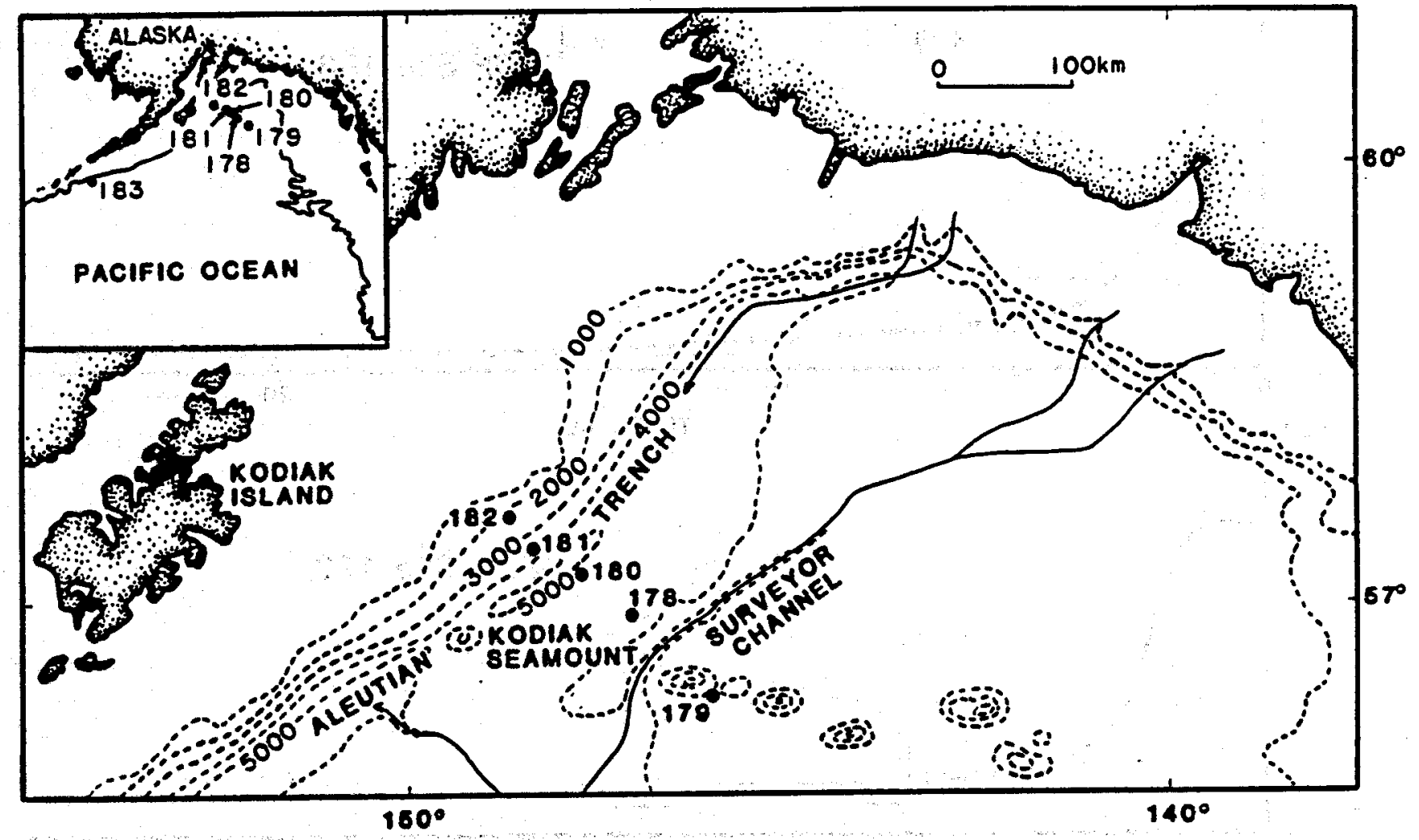

\begin{tabular}{|c|c|c|c|}
\hline DSDP SITE & LOCATION & $\begin{array}{c}\text { DEPTH BELOW } \\
\text { BEA LEVEL. } \\
m\end{array}$ & $\begin{array}{l}\text { DEPTH BELOW } \\
\text { SEA FLOOR. } \\
\mathrm{m}\end{array}$ \\
\hline $\begin{array}{l}177 \\
178 \\
170 \\
180 \\
181 \\
182 \\
182 A \\
183\end{array}$ & 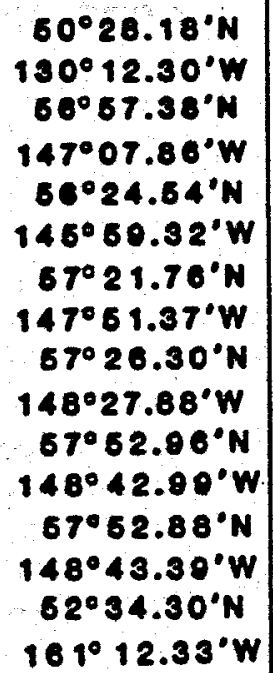 & $\begin{array}{r}2006 \\
4218 \\
3781 \\
4029 \\
3086 \\
1410 \\
1434 \\
4708\end{array}$ & $\begin{array}{l}607 \\
704.6 \\
100 \\
470.6 \\
360 \\
123 \\
105 \\
605\end{array}$ \\
\hline
\end{tabular}

Figure 46. LOCATIONS OF DSDP SITES (LEG 18) IN EASTERN ALEUTIAN TRENCH-ARC SYSTEM 


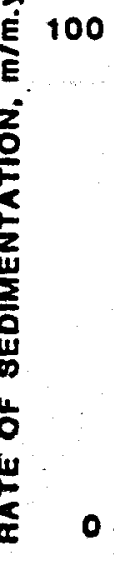

8
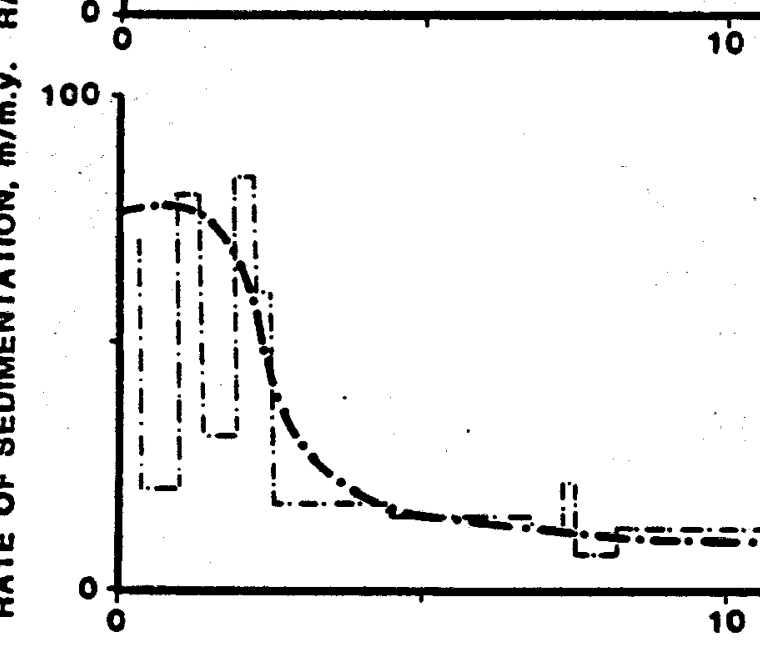

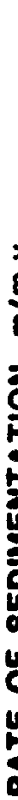

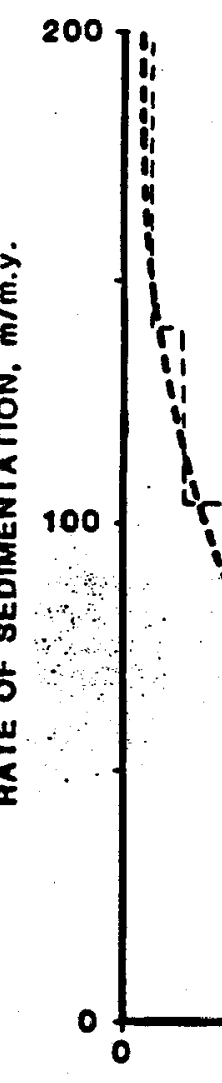

DSDP Site 183

1

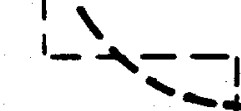

$-$

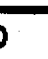

TIME, M.Y.

20

DSDP Site 173

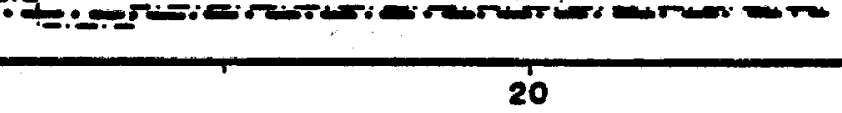

TIME, m.y.

DSDP Site 178

Figure 47. RATE OF SEDIMENTATION AT DSDP SITES OF LEG 18 After von Huene, 1973 
the latter area seem to indicate that the southeastern shores of Alaska supplied sediment during early Miocene, whereas during the sedimentation of upper Pleistocene sequences southwestern Alaska appears to be the sediment source of Site 178. The increasing frequency of volcanic ash falls in the area from Pliocene and Pleistocene time is another characteristic feature reflected in the lithostratigraphic profile of Site 178 (Pratt et al., 1973). Volcanic activity was initiated at early Pliocene and led to the development of the present Alaska Peninsula. The peak of this activity occurred approximately 1 m.y. ago.

Aleutian Trench. Knowledge of lithofacies at Site 180 is incomplete due to the poor core recovery in the silt and turbidite intervals. On the basis of glacial geochronology and fragmentary rock samples it was concluded that bottom-drilled sediments at Site 180 are $0.3 \quad( \pm 0.05)$ m.y. old (von Huene and Kulm, 1973). Further studies including seismic and paleomagnetism data enabled the latter authors to assess the age of the oldest sediments in the trench to be $0.6 \pm 0.1$ m.y.

The sedimentation in the trench and the facies pattern is controlled by the abundance and character of the landward source. Turbidity currents and slides move the sediment down the continental slope making up about $90 \%$ of the trench fill. Sediment from the slope is eventually redistributed along the broad axial channel at the base of the slope. Sands are mostly deposited in the channel whereas lower-size graded material is transported to the overbank areas. The latter sediments were probably encountered at Site 180. Average sedimentation rate at the deepest part of the trench was approximately 1,780 $\mathrm{m} / \mathrm{m} . \dot{y}$. with possible increased values during glaciation periods.

Lower Continental Slope. Deformation of sediments has been detected in a core sample from Site 181. Two distinct lithologies separated by an unconformity were observed in this core: the upper section represents lower continental slope sediments made up of muds and graded sands which appear on the seismic section as a tilted and mildly deformed formation, whereas the underlying section of unknown origin consists of highly deformed sediments and probably corresponds to the "basement" on seismic sections. Considering the fact that only the upper $70 \mathrm{~cm}$ of the core exhibits hemipelagic sediments where Site 181 is located on an isolated knoll it was concluded that the site area was upliffed $465 \mathrm{~m}$ (Hayes, 1973). The conservative calculations yielded the value of rate of the uplift $2,200 \mathrm{~m} / \mathrm{m} . \mathrm{y}$. The knowledge of the original provenance of both mentioned groups of sediments of the lower continental slope is inadequate and subsequently the establishment of mechanisms at their deposition and deformation is not possible at the present time.

Detailed Lithostratigraphy. The most detailed lithostratigraphy of the eastern Aleutian Trench-Arc system and adjacent abyssal plains areas has been established on the basis of DSDP cruises of Legs 18 and 19 data. Specifically, five DSDP sites (Sites 178, 180, 181, 182, 183) are located in the area of the eastern Aleutian Trench-Arc system.

Site 178 (Figure 48) was located on the abyssal plain, $330 \mathrm{~km}$ southwest of Kodiak Island and south of the Aleutian Trench (Figure 46). The sediments 
at this site were cored to the depth of $777.5 \mathrm{~m}$ where the basaltic basement was encountered. The oldest sediments are of early Miocene age. The contact between the basalt and overlying clay shale did not show any signs of baking. The lowermost part of the sedimentary sequence consists of $29 \mathrm{~m}$ of clay shale devoid of microfossils. At a depth of $742 \mathrm{~m}(2,433.7 \mathrm{ft})$ the $6.5 \mathrm{~m}$ $(21.3 \mathrm{ft})$ thick unit of interbedded chalk and brown to olive gray claystone was found. The interval of 742 to $280 \mathrm{~m}(2,433.7$ to $918.4 \mathrm{ft})$ is composed of silty clay, diatomaceous sediments and thin bedded, poorly sorted, and very fine sand turbidites in various proportions. The uppermost $280 \mathrm{~m}(918.4 \mathrm{ft})$ of the lithological sequence in Site 178 is represented by thick bedded silty clay with sand to pebble-sized metamorphic and sedimentary erratics. Fourteen sedimentary units have been distinguished in the profile of Site 178, on the basis of proportions of various lithologic types (von Huene et al., 1973).

Unit $1,0-96.0 \mathrm{~m}(0-314.8 \mathrm{ft})$. Medium dark gray silty clay is the major lithological component of this interval. It commonly contains erratics which are particularly abundant in two zones: from 24 to $33 \mathrm{~m}$ and from 60 to 96 m. Their lithologies comprise of graywacke, sandstone, shale, and amphibolite. Silt material is very rare. Several layers of light volcanic ash (1 to $14 \mathrm{~cm}$ thick, i.e. 0.4 to 5.5 inches) were detected in the interval. An interesting feature of this lithological unit is the noticeable lack of diatoms.

Unit 2, 96.0-141.0 m (314.8-462.4 ft) is composed of medium dark gray silty clay. documented in the general interval. Silty clay diatom oozes have been found at depths of $100 \mathrm{~m}(328 \mathrm{ft}), 106 \mathrm{~m}(347.6 \mathrm{ft}), 135 \mathrm{~m}(442.8 \mathrm{ft}), 137 \mathrm{~m}$ (449.3 ft) and were $8 \mathrm{~cm}$ ( 3 inches), $10 \mathrm{~cm}$ (3.9 inches), $5 \mathrm{~cm}$ (1.9 inches), and 215 $\mathrm{cm}(7 \mathrm{ft})$ thick. Silt proved to be a minor element in Unit 2.

Unit $3,141.0-280.0 \mathrm{~m}(462.4-918.4 \mathrm{ft})$. This unit consists mainly of silt layers interbedded with silty clays and volcanic ashes. The silt layers are mostly 2-20 mm (0.07-0.8 inches) thick. A few layers of light volcanic ash 1 to $5 \mathrm{~cm}(0.4$ to 2 inches) thick and two layers $50 \mathrm{~cm}(19.7$ inches) and $3 \mathrm{~cm}$ (1.2 inches) thick were detected at $152 \mathrm{~m}(498.5 \mathrm{ft})$ and $224 \mathrm{~m}(734.7 \mathrm{ft})$.

Unit 4, 280.0-357.0 $\mathrm{m}$ (918.4-1,170.9 $\mathrm{ft})$. The unit is represented prędominantly by diatomaceous sediments interbedded with layers of silty clay, poorly sorted silt, to very fine sand turbidites. The silty clayey sediments range in color from olive, gray, dark greenish gray to greenish gray. The diatom concentrations tend to increase towards the greenish gray sediment. The sand and silt turbidite intervals attain as much as $55 \mathrm{~cm}$ (21.6. inches) in thickness with an average 2 to $15 \mathrm{~cm}(0.8$ to 5.9 inches $)$. The turbidites constitute 50 to $10 \%$ of the upper part of Unit 4 with general increase downward to $30 \%$.

Unit $5,357.0-410.0 \mathrm{~m}(1,170.9-1,344.8 \mathrm{ft})$. The lithological profile of this unit consists of predominantly olive-gray to greenish gray silty clay and diatom-bearing silty clay or diatom ooze. There is a general lack of sandy and silty turbidites. Thin interbeds of olive-gray silt have been noticed at subinterval 392 to $399 \mathrm{~m}(1,285.7$ to $1,308.7 \mathrm{ft})$. Silt appears to be well sorted, composed mostly of quartz with same carbonates. 


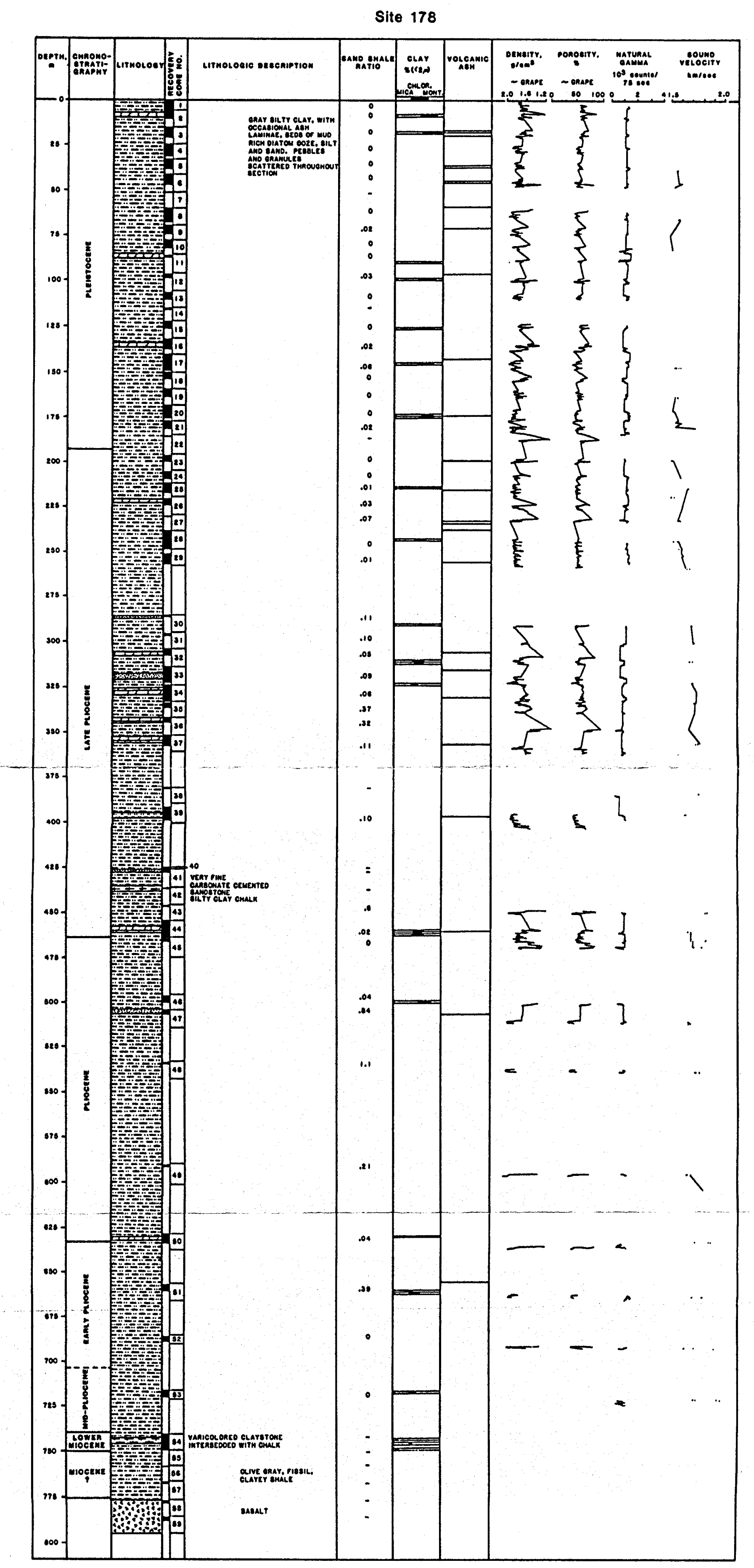

$<$ 
Unit $\underline{6}, \underline{410.0-456.0} \mathrm{~m}(1,344.8-1,495.7 \mathrm{ft})$ comprises thin layers of poorly sorted silt and very fine sand turbidites interbedded with olive-gray and dark greenish gray silty clays. The turbidite layers are frequently up to $25 \mathrm{~cm}$ (9.8 inches) thick and probably constitute $35 \%$ of the entire Unit section. At a depth of $447 \mathrm{~m}(1,466.2 \mathrm{ft})$ well preserved pebble-sized mud clasts have been found above a basal sand. The calcium-carbonate matrix has been identified in the core from a depth of $437 \mathrm{~m}(1,433.4 \mathrm{ft})$.

Unit $7_{2} 456.0-505.0 \mathrm{~m} \frac{(1,495.7-1,656.4}{\mathrm{ft}) .}$ This lithological unit is characterized by olive-gray to dark greenish gray silty clay with intervals of greenish gray clayey diatom ooze and sometimes clay-bearing diatom ooze. Beds of very fine sand also occur; however, these occurrences are rare.

Unit $8_{2}$ 505.0-560.0 $\mathrm{m}(1,656.4-1,836.8 \mathrm{ft})$. The rocks in Unit 6 are mainly represented by poorly sorted silt and very fine sand turbidites. The layers of sand and silt which comprise $30-50 \%$ of the interval vary in thickness from 1 to $40 \mathrm{~cm}(0.4$ to 15.7 inches). Carbonate-cemented siltstones were cored at the depth of $553 \mathrm{~m}(1,813.8 \mathrm{ft})$.

Unit 9 , 560.0-630.0 $\mathrm{m}$ (1,836.8-2,066.4 ft). Olive-gray and dark greenish gray silty clay shales constitute a major lithotype in the upper part of this interval. At the interval of 630 to $615 \mathrm{~m}(2,017.2$ to $2,066.4 \mathrm{ft})$ diatomaceous sediments are present. A $150 \mathrm{~cm}$ (59 inches) thick greenish gray diatom ooze bed has been identified at the depth 631 to $632.5 \mathrm{~m}(2,069.6$ to 2,074.6 ft).

Unit $10,630.0-688.0 \mathrm{~m}$ (2,066.4-2,256.6 $\mathrm{ft})$ is composed of thin-bedded poorly sorted silt and very fine sand turbidites and olive-gray to dark greenish gray silty clays with rare diatomaceous sediments.

Unit 11, 688.0-742.0 $\mathrm{m}$ (2,256.6-2,433.7 ft) consists of hard, olive-gray and dark greenish gray silty clays. The biogenous materials are extremely rare in this interval.

Unit $12,742.0-775.5 \mathrm{~m} \quad(2,433.7-2,455.0 \mathrm{ft})$. This unit is represented by interbedded chalk and claystone of varying color. Four layers of olive-gray, light greenish gray and grayish orange-pink chalk 25-60 cm (9.8-23.6 inches) thick have been identified in this interval. The claystone intervals are 25 to $300 \mathrm{~cm}$ (9.8 to 118 inches) thick which separate the chalk layers range in color from dark yellowish brown to light olive-gray and pale yellowish brown. Some claystones are composed of as much as $20 \%$ diatoms and radiolarians. The entire unit shows signs of predominantly horizontal burrowing.

Unit $13,748.5-775.5 \mathrm{~m}(2,455-2,550 \mathrm{ft})$ is represented by olive-gray and dark yellowish brown clay shale.

Site 180 (Figure 49). The position of DSDP Site 180 was necessitated by the lack of sedimentological data from the active area of the eastern Aleutian Trench. Site 180 was located in the northeastern basin within the trench, formed by Kodiak Seamount flanking the basin from the southwest. The drilling site is about $16 \mathrm{~km}$ from the continental slope where about 500 
Site 180

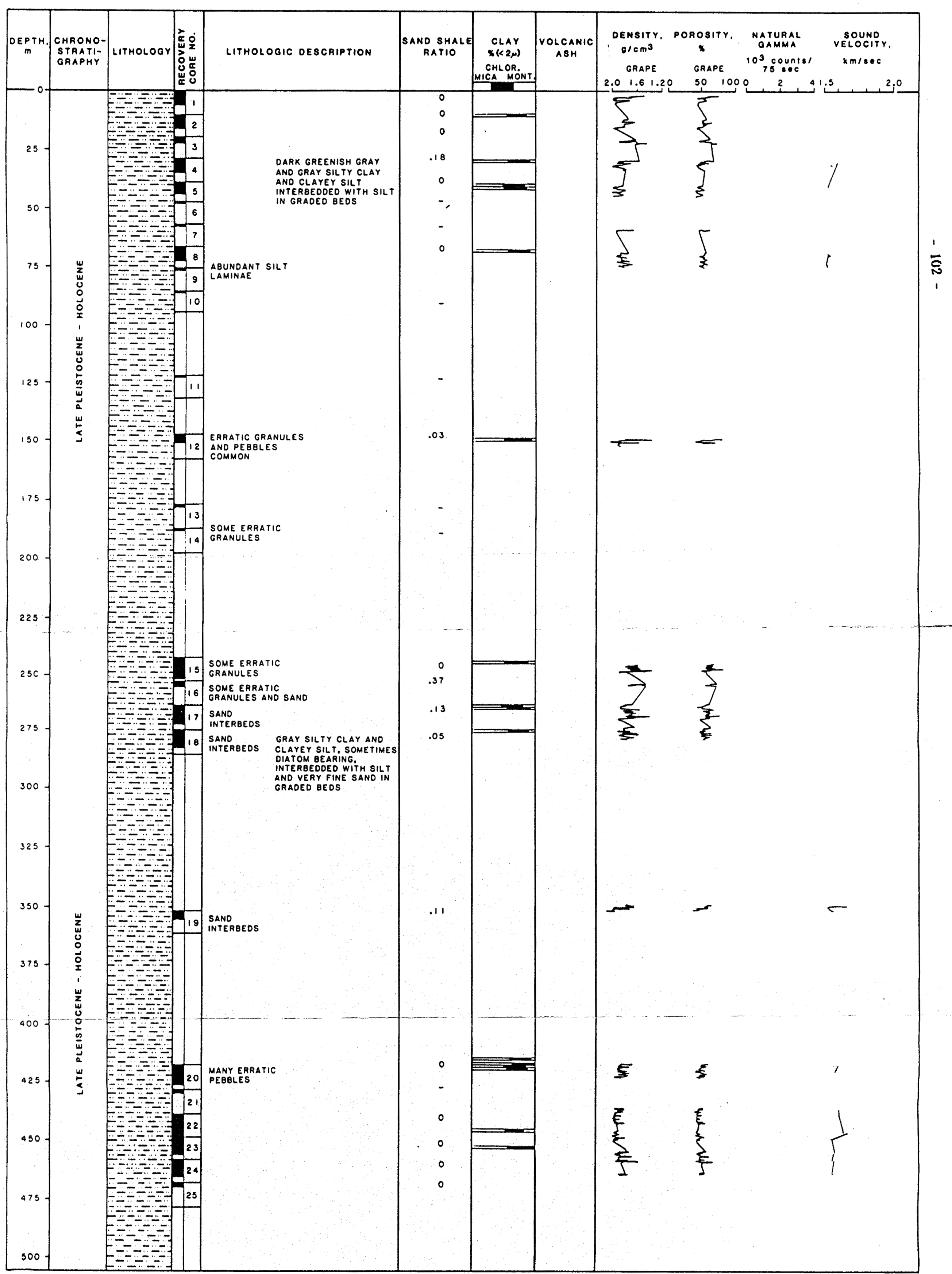

Figure 49. LITHOSTRATIGRAPHY AND PHYSICAL PROPERTIES OF SEDIMENTS AT DSDP LEG 18, SITE 180 
$m$ of trench fill is present. Below the fill the sedimentary sequence consists of turbidites and hemipelagic sediment encountered at Site 178. The sediments at Site 180 of late Pleistocene and Holocene age were drilled and cored to the subbottom depth of $470.5 \mathrm{~m}$. The recovered rock samples contained upper Pleistocene silt turbidites, interbedded, muds with silt and glacial erratics. Calcareous nannoplankton was found to be rare and to occur in the upper section of the drilled interval only. The fact that the deposition area at Site 180 is well below the carbonate compensation level leads to the conclusion that all observed calcareous nannofossils were redeposited from a eroded shallow shelf being transported to the trench floor by turbidity currents and subsequently buried under the circumstances of a high sedimentation rate. The entire sedimentary section at Site 180 has been divided into seven units on the basis of the amount of silt, type of bedding and presence of ice-rafted erratic rocks (von Huene et al., 1973):

Unit 1, 0-2.0 m $(0-6.5 \mathrm{ft})$ consists of dark greenish gray mud. The occasional coarse silt beds were found at the base of the unit. Also a $10 \mathrm{~cm}$ (3.9 inches) ash bed has been identified at the top of the interval.

Unit $2,2.0-240.0 \mathrm{~m}(6.5-469.2 \mathrm{ft})$. In the lithological composition of this interval two major elements are gray muds and beds of silt. There is little biogenous material while no ice-rafted erratics are present. Two facies of sediments In Unit 2 have been described by von Huene et al. (1973). One is represented by mud with 5 to $15 \%$ of mostly medium size silt. The silt material occurs in thin graded beds 0.5 to $2 \mathrm{~cm}$ thick. Silt was of ten found in single or grouped laminae in mud, showing various level of sorting. Such lamination and material type seems to indicate the environment of turbidites. Another facies of mud contains 15 to $60 \%$ interbedded silt and very fine sand. Silt and sand occur in poorly graded beds varying in thickness from 5 to 40 cm.

Unit $3,140.0-165.0 \mathrm{~m}$ (469.2-541.2 $\mathrm{ft})$ is represented by gray muds with interbedded graded beds of silt and occasionally sand. Muds were found to contain granules and pebbles, perhaps ice-rafted. Sands appear to be of very fine grade. Most silt beds are 5 to $10 \mathrm{~cm}$ (1.9 to 3.9 inches) thick with maximum reaching $53 \mathrm{~cm}(20.8$ inches).

Unit 4, 265.0-315.0 m (869.2-1,033.2 ft). The unit consists of mostly dark graying gray mud. Muds contain usually 2 to $10 \%$ diatoms. Silts occur predominantly in beds of $2-15 \mathrm{~cm}(0.8-5.9$ inches) thick. No rafted pebbles or granules have been observed.

Unit $5,315.0-390.0 \mathrm{~m}(1,033.2-1,279.2 \mathrm{ft})$. This unit is made in $40 \%$ of

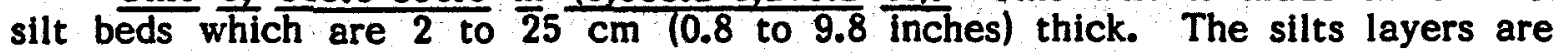
interbedded with medium gray mud. There are no erratic rocks found in this unit.

Unit 6, 390.0-462.0 $\mathrm{m}(1,279.2-1,515.3 \mathrm{ft})$. The medium gray mud almost entirely devoid of biogenic material seems to be a major component in this interval. The silt occurrence frequency is less than $10 \%$. Coarse and medium silt was found in graded beds up to $8 \mathrm{~cm}$ thick. At the depth of $415 \mathrm{~m}$ $(1,367.2 \mathrm{ft})$ volcanic ash was identified. 
Unit 7, 462.0-470.5 $\mathrm{m}(1,515.3-1,543.2 \mathrm{ft})$. This unit is composed mostly of graded beds of silt (approximately $50 \%$ ) interbedded with muds.

Site 181 (Figure 50). This drill hole was located on a steep ridge of the lower continental slope approximately $2,000 \mathrm{~m}(6,550 \mathrm{ft})$ above the Aleutian Trench floor. At Site $181,369 \mathrm{~m}(1,210 \mathrm{ft})$ of the sedimentary sequence of Pleistocene and Holocene rocks was drilled and cored. According to von Huene et al. (1973) the entire penetrated sequence exhibits three distinctive units:

Unit 1, 0-117.0 $\mathrm{m}(0-383.7 \mathrm{ft})$. A medium dark gray, soft to firm, uniform silty clay constitutes the dominant type of sediment. Diatom-rich silty clay, fine to coarse silt, and beds of very fine sand are interbedded with the silty clay.

Unit 2, 117.0-169.0 $\mathrm{m}((383.7-554.3 \mathrm{ft})$ is characterized by lithologies ranging from diatom-bearing silty clays in the upper part to diatom ooze with $60 \%$ diatoms at the bottom. Two layers of very fine sand to silty (5 to 10 $\mathrm{cm}$ thick, i.e. 1.9 to 3.9 inches) with sharp boundaries have been described in this interval. The sediments show a progressive increase in degree of induration toward the bottom.

Unit $3,169.0-369.0 \mathrm{~m}$ (554.3-1,210.3 ft) consists of dark gray to olivegray and olive-black highly contorted compact mudstone with faint bedding. The contorted structures were particularly noticeable where silt laminae occur. Some zones of heterogenous poorly sorted medium to coarse sand in a silty clay as well as erratics have been also observed.

Site 182 (Figure 51) was located in the area of the upper continental slope off Kodiak Island. The sequence of $123 \mathrm{~m}$ of Pleistocene sediments was drilled and cored at this site. Core recovery at Site 182 was poor (approximately $21 \%$ ), and the lithostratigraphic control of the well is relatively weak.

On the basis of available rock samples two types of lithologies have been recognized (von Huene et al., 1973):

1. Clayey silt - frequently coarse and sandy. Mottles of medium and fine grained sand occasionally mixed with some volcanic ash were identified within clayey silt sections. The medium gray clayey silt was found to be interbedded with dark greenish gray clayey silt and with olive-gray clayey silt. Biogenous components constitute up to $4 \%$ of the clayey silt intervals. The erratic granules and pebbles were sporadically found in the amount of 0.1 to $5 \%$.

2. Sands were encountered below $95 \mathrm{~m}$ of subbottom depth. These sands are fine-grained, well sorted, and devoid of the erratic material.

Site 183 was positioned near the northern edge of the Aleutian Abyssal Plain in the western Gulf of Alaska (Figure 52). The basaltic basement was encountered at $505 \mathrm{~m}$ of subbottom depth. The rocks of the upper part of 
Site 181

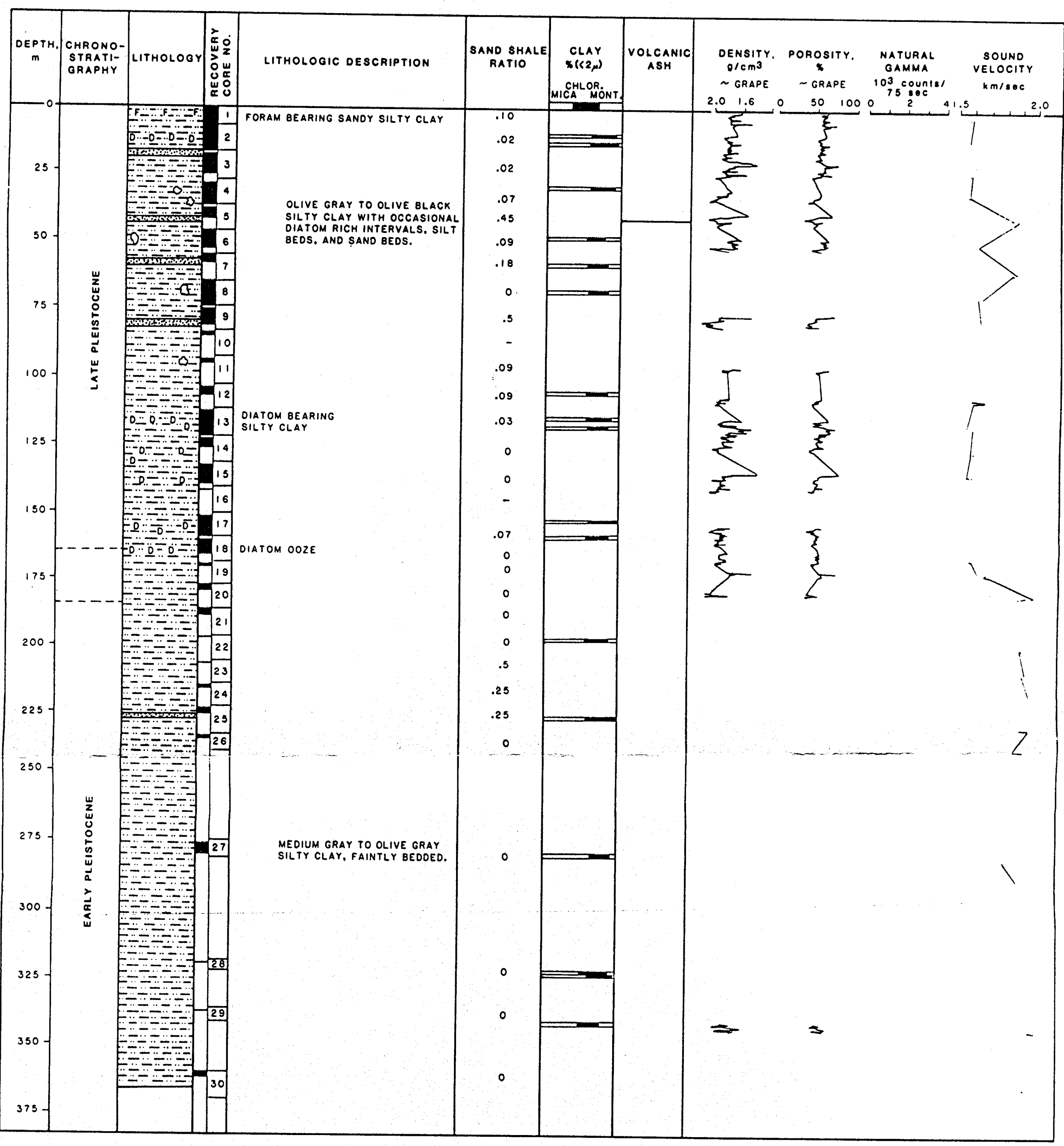

Figure 50. LITHOSTRATIGRAPHY AND PHYSICAL PROPERTIES OF SEDIMENTS AT DSDP LEG 18, SITE 181 


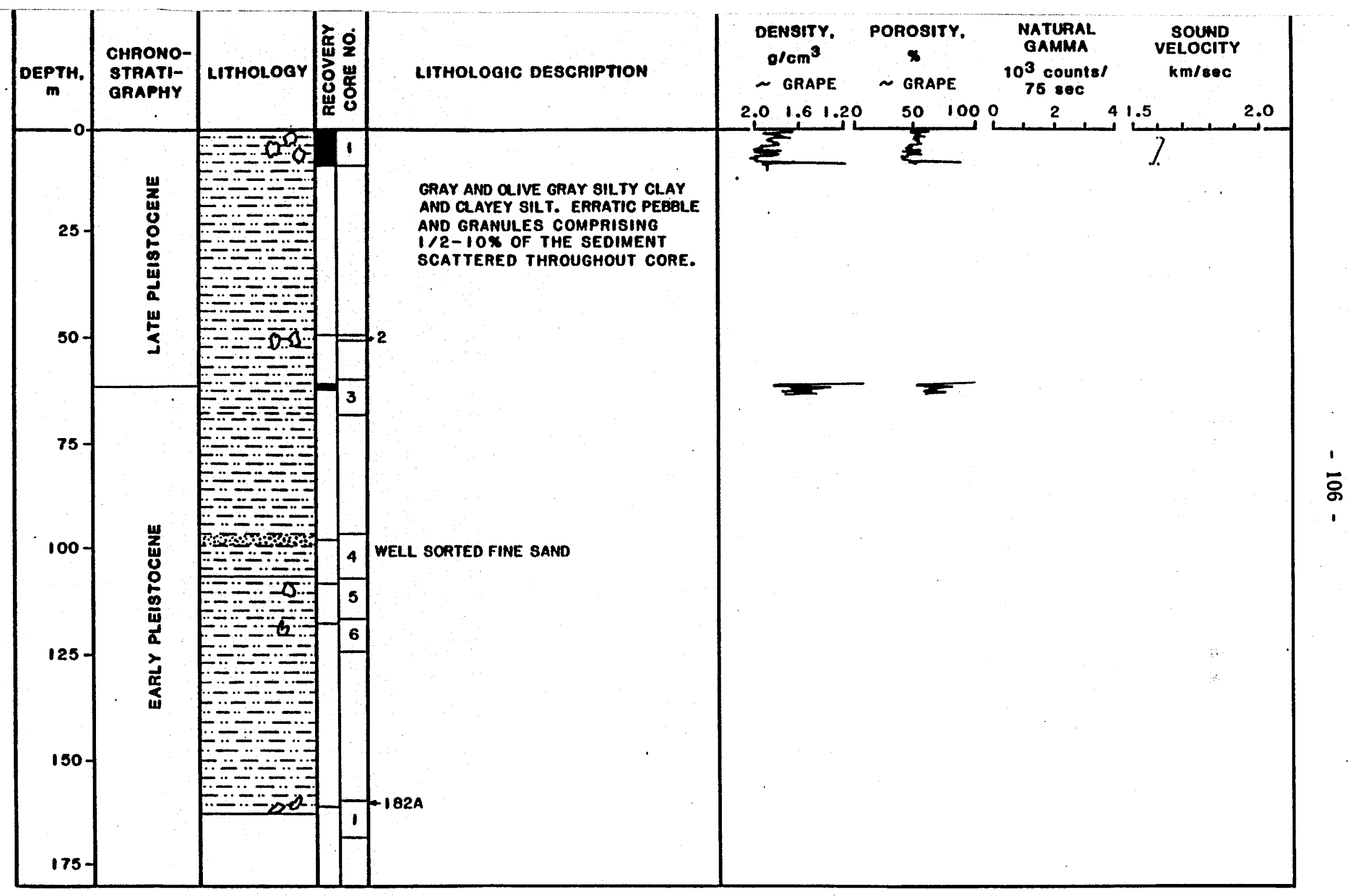

Figure 51. LITHOSTRATIGRAPHY AND PHYSICAL PROPERTIES OF SEDIMENTS AT DSDP LEG 18, SITE 182

After von Huene et al., 1973 
Site 183

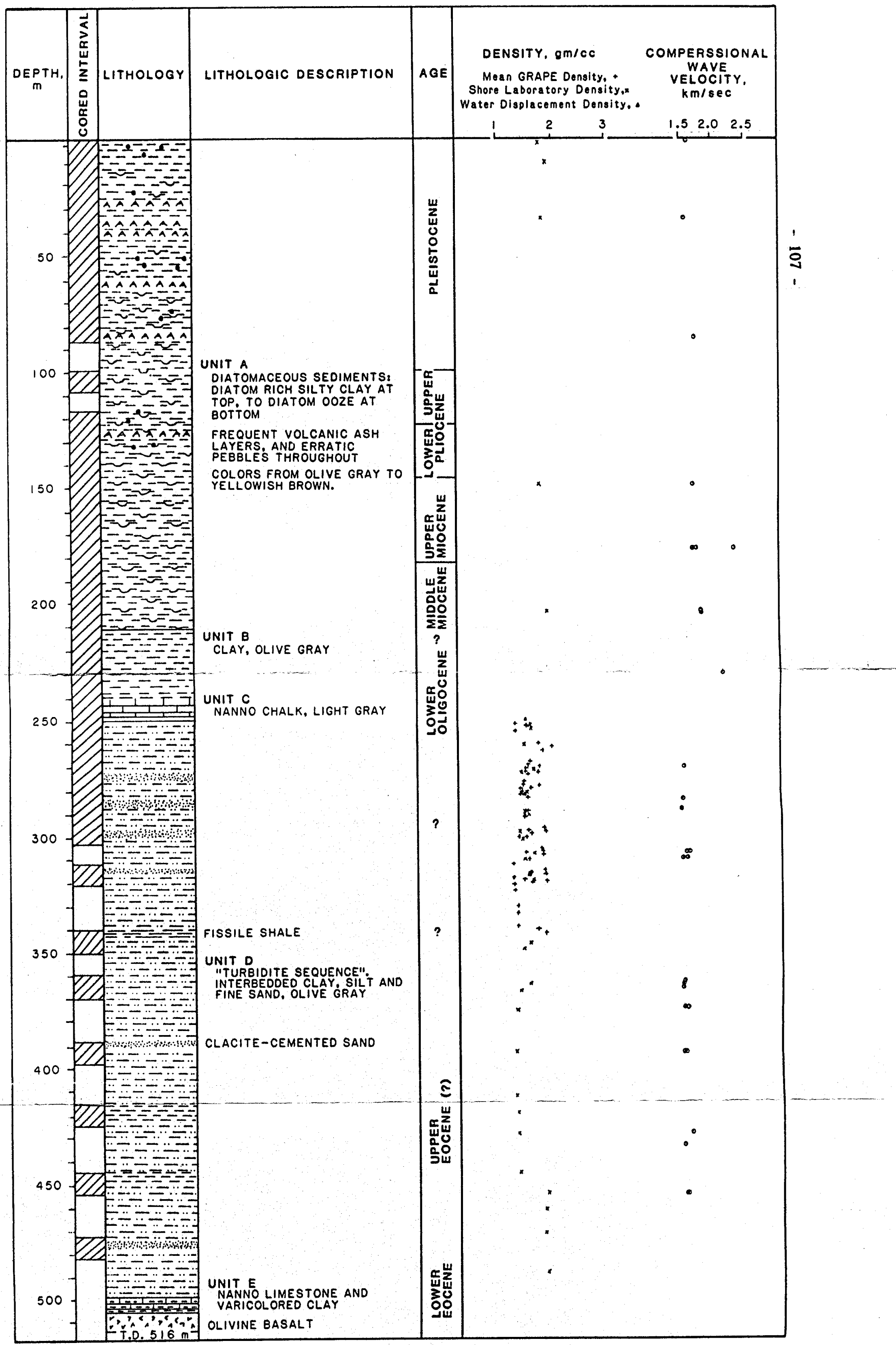

Figure 52. LITHOSTRATIGRAPHY AND PHYSICAL PROPERTIES OF SEDIMENTS AT DSDP LEG 19, SITE 183 
the basement were assessed to be older than late early Eocene age. Overlying the basement the sedimentary sequence consists of: (a) nannofossil limestone, calcareous ferruginous clay and pyritic, aragonitic limestone $(505$ to $510 \mathrm{~m}$, i.e. 1,656.4 to 1,643.2 ft) of upper Eocene (?) age; (b) turbidite beds (501 to $248 \mathrm{~m}$, i.e. $1,643.2$ to $813.4 \mathrm{ft}$ ) of lower Oligocene to upper lower Eocene age, represented by clay with layers of silts and silty sand exhibiting increasing frequency downward; (c) nannofossil chalk (248 to $239 \mathrm{~m}$, i.e. 813.4 to $783.9 \mathrm{ft}$ ) deposited during the lower to middle Oligocene epoch; (d) pelagic clays (239 to $210 \mathrm{~m}$, l.e. 783.9 to $688.8 \mathrm{ft}$ ) of upper Oligocene to lower Miocene age; (e) pelagic sediments $(210$ to $0 \mathrm{~m}$, l.e. 688.8 to $0 \mathrm{ft})$ deposited from Holocene through middle Miocene time are represented by diatom-rich silty clay and diatom ooze. Intercalations of volcanic ash layers have been found in the upper $185 \mathrm{~m}(606.8 \mathrm{ft})$ section of the profile. Also erratic pebbles (ice-rafted ?) were Identified in some intervals above $127 \mathrm{~m}(416.5 \mathrm{ft}$ ) of depth at Site 183.

The entire sedimentary sequence penetrated at Site 183 exhibits distinct features which enabled Scholl et al. (1973) to divide it into five units:

Unit 1, 0-210.0 $\mathrm{m}$ (0-688.8 ft). The sediments in this interval are represented mostly by silty clay which usually is diatom-rich, and by thick layers of diatom ooze. Beds of volcanic ash up to $0.4 \mathrm{~m}(15.7$ inches) thick frequently occur about $185 \mathrm{~m}(606.8 \mathrm{ft})$. Two types of ash prevail: one is a light gray ash consisting mainly of colorless fragments of glass whereas another type occurs as dusky yellowish-brown glass particles. The interval between 210 to $185 \mathrm{~m}(688.8$ to $606.8 \mathrm{ft})$ however consists of diatom ooze, it does not contain beds of volcanic glass. The ooze is yellowish brown to dark brown and is mottled and streaked with thin reddish brown zones. The erratic fragments (ice-rafted ?) occur mostly in the upper $127 \mathrm{~m}(416.5 \mathrm{ft}$ ) of Unit 1 and are particularly abundant at the depth intervals 0 to $11 \mathrm{~m}(0$ to $36 \mathrm{ft}$ ), 50 to $59 \mathrm{~m} \mathrm{(164} \mathrm{to} 193.5 \mathrm{ft}), 70$ to $78 \mathrm{~m}(229.6$ to $255.8 \mathrm{ft}), 118$ to $119 \mathrm{~m}$ (387.0 to $390.3 \mathrm{ft}$ (, and 126 to $127 \mathrm{~m}(413.2$ to $416.5 \mathrm{ft}$ ).

Unit $2,210.0-239.0 \mathrm{~m}$ (688.8-783.9 $\mathrm{ft}$ is composed of pale olive-gray clay mottled and banded with greenish-gray to dark gray clay. The bands vary in thickness from 0.5 to $40 \mathrm{~cm}(0.2$ to 15.7 inches).

Unit $3,239.0-248.0 \mathrm{~m}$ (783.9-813.4 ft). A small fraction of the recovered core revealed a lithological unit of light gray clay-rich nannofossil chalk.

Unit $4,248.9-501.0 \mathrm{~m}$ (813.4-1,643.2 $\mathrm{ft})$. The recovered sediment from this interval is predominantly olive-gray clay with interbeds of silts and fine-grained sands. Beds of graded sand attain a thickness of as much as $1 \mathrm{~m}$ (3.3 ft). The layers of greenish gray calcite-cemented sand are particularly frequent between 388.5 and $390.5 \mathrm{~m}(1,274.2$ and $1,280.8 \mathrm{ft})$. Petrographic studies of thin sections from sand intervals revealed the presence of K-feldspar (10\%), plagioclase $(20-30 \%)$, quartz $(30-40 \%)$, and calcite cement $(30-40 \%)$. Very fine laminated shale was recovered from the interval 341 to $350 \mathrm{~m}$ whereas the specimen of dark gray organic-rich shale containing 5 to $10 \%$ wood fragments was described from the depth of 444.5 to $445 \mathrm{~m}(1,457.9$ to $1,459.6 \mathrm{ft}$; Wolfe, 1973). 
Unit $5,501.0-505.0 \mathrm{~m} \quad(1,643.2-1,653.4 \mathrm{ft})$ is represented by a bluish white nannofossil limestone separated from a dark greenish nanno-limestone by dark yellowish brown calcareous clay. It is suspected that as much as $23 \mathrm{~m}$ $(75.4 \mathrm{ft})$ of pelagic sediment may be present above the basalt-sediment contact.

\section{Organic Matter}

A number of geochemical analyses of sediments have been performed with regard to the potential of hydrocarbon generation in the Aleutian Trench area. Most of the analytical samples were collected at DSDP drilling sites $178,180,181$, and 183. Some of these results, with the geochemical results of six dredge samples from USGS cruise S-79-WG, were published by Bode (1973) and Kvenvolden and Von Huene (1985; Tables 11 and 12 and Figures 53-56). Even a cursory review of the listed results shows a low content of total organic carbon (TOC) in all analyzed samples. The TOC values range from traces to $0.8 \%$, averaging $0.6 \%$. Geochemical data obtained from thermal evolution analysis (TEA), known also as pyrolysis, seem to be in agreement with the variations in organic carbon content. The. TEA technique presented by Claypool and Reed (1976) provides some important characteristics of the organic matter. One of these characteristics is the total hydrocarbon yield which is usually expressed in percent of organic carbon. Volatile hydrocarbons released during pyrolysis are measured in part per million of the total hydrocarbon yield. The temperature at which the maximum hydrocarbons are thermally released is often referred to as $T_{\max }$ and is expressed in degrees Celsius. "Live carbon" reflects the amount of carbon which effectively enters into the process of hydrocarbon generation upon thermal evolution and is defined as a ratio of total hydrocarbon yield to the original amount of organic carbon. The results of the geochemical analyses are shown in Figure 12.

The total hydrocarbon yield from all sediment samples from the Aleutian Trench area proved to be low, ranging from 0.03 to $0.10 \%$. Subsequently, the values of "live carbon" were mostly found to be less than $25 \%$, whereas the content of volatile hydrocarbons does not exceed $200 \mathrm{ppm}$. The result of pyrolysis also shows the maximum of thermal cracking of the organic matter in temperatures between 298 to $523^{\circ} \mathrm{C}\left(748\right.$ to $\left.973^{\circ} \mathrm{F}\right)$.

Although the revealed geochemical features of the organic matter are not sufficient to carry on the correlation among the DSDP sites related to spatial changes of the organic matter through the entire area, they provide valid data for general assessment of sediment potential to generate hydrocarbons.

The content of the total organic carbon (TOC) in all analyzed samples indicates low hydrocarbon potential of the sediments, considering the fact that the lower limit of TOC content indispensable for hydrocarbon generation is generally agreed to be $0.5 \%$ (Hunt, 1979; Tissot and Welte, 1984). The results of analyses of total hydrocarbon yield, "live carbon" and volatile hydrocarbon content, confirm low hydrocarbon potential of the examined samples. According to Magoon and Claypool (1981), organic matter with lower than 30\% values of "live carbon" usually indicates potential for gas rather than oil generation. The temperatures at which the maximum of the organic matter in the analyzed samples was thermally decomposed ranged mostly from 422 to $480^{\circ} \mathrm{C}$ and rarely exceeded $490^{\circ} \mathrm{C}$ (Table 12 ). 
TAB́LE 11.

RESULTS OF GEOCHEMICAL ANALYSES OF KEROGEN FROM EASTERN ALEUTIAN TRENCH. After Kvenvolden and von Huene, 1985.

\begin{tabular}{|c|c|c|c|c|c|c|c|c|c|c|}
\hline $\begin{array}{c}\text { Sample } \\
\text { No. }\end{array}$ & $\begin{array}{l}\text { Hydrogen } \\
\text { Index(HI) } \\
\frac{\mathrm{mg} \mathrm{HC}}{\mathrm{g} \text { OC }}\end{array}$ & $\begin{array}{l}\begin{array}{l}\text { Oxygen } \\
\text { Index(O) }\end{array} \\
\frac{\mathrm{mg} \mathrm{CO}_{2}}{\mathrm{~g} \mathrm{OC}}\end{array}$ & $\mid \begin{array}{c}\text { Vitrinite } \\
\text { Reflectance }\left(\mathbf{R}_{\mathbf{b}}\right) \\
\mathbf{R}_{\mathbf{0}} \\
\%\end{array}$ & $\begin{array}{l}\text { Total } \\
\text { Alteration } \\
\text { Index } \\
\text { TAI }\end{array}$ & $\%$ & Vitrinite & Inertinite & \begin{tabular}{|} 
Recycled \\
Vitrinite \\
$\%$
\end{tabular} & $\begin{array}{c}\text { Recycled } \\
\text { Sporinite } \\
\%\end{array}$ & $\begin{array}{c}\text { Other } \\
\text { Amorphous } \\
\\
\%\end{array}$ \\
\hline $\begin{array}{r}6 \\
14 \\
16 \\
17 \\
19 \\
21 \\
27 \\
33 \\
34\end{array}$ & $\begin{array}{r}270 \\
95 \\
223 \\
130 \\
156 \\
119 \\
245 \\
160 \\
122\end{array}$ & $\begin{array}{r}202 \\
92 \\
136 \\
50 \\
91 \\
53 \\
105 \\
71 \\
111\end{array}$ & $\begin{array}{l}0.40 \\
0.40 \\
0.45 \\
0.36 \\
0.47 \\
0.46 \\
0.45 \\
0.50 \\
0.38\end{array}$ & $\begin{array}{l}2.0 \\
1.5 \\
2.0 \\
2.0-2.3 \\
2.4-2.6 \\
2.0-2.3 \\
2.0-2.4 \\
2.3-2.5\end{array}$ & $\begin{array}{l}4 \\
1 \\
- \\
4 \\
3 \\
- \\
2 \\
5 \\
7\end{array}$ & $\begin{array}{l}32 \\
13 \\
12 \\
38 \\
39 \\
13 \\
14 \\
20 \\
15\end{array}$ & $\begin{array}{r}26 \\
7 \\
6 \\
13 \\
4 \\
- \\
10 \\
5 \\
-\end{array}$ & $\begin{array}{l}24 \\
68 \\
62 \\
40 \\
32 \\
18 \\
28 \\
30 \\
24\end{array}$ & $\begin{array}{r}4 \\
7 \\
- \\
5 \\
18 \\
7 \\
- \\
10 \\
16\end{array}$ & $\begin{array}{r}10 \\
6 \\
20 \\
- \\
4 \\
2 \\
48 \\
30 \\
40\end{array}$ \\
\hline
\end{tabular}

$O C=$ Organic Carbon

$\mathrm{HC}=$ Hydrocarbons

Sample numbers correspond to those listed in Table 12. 
RESULTS OF GEOCHEMICAL ANALYSES OF THE ORGANIC MATTER IN ROCK SAMPLES FROM EASTERN ALEUTIAN TRENCH AREA. After Kvenvolden and von Huene, 1985.

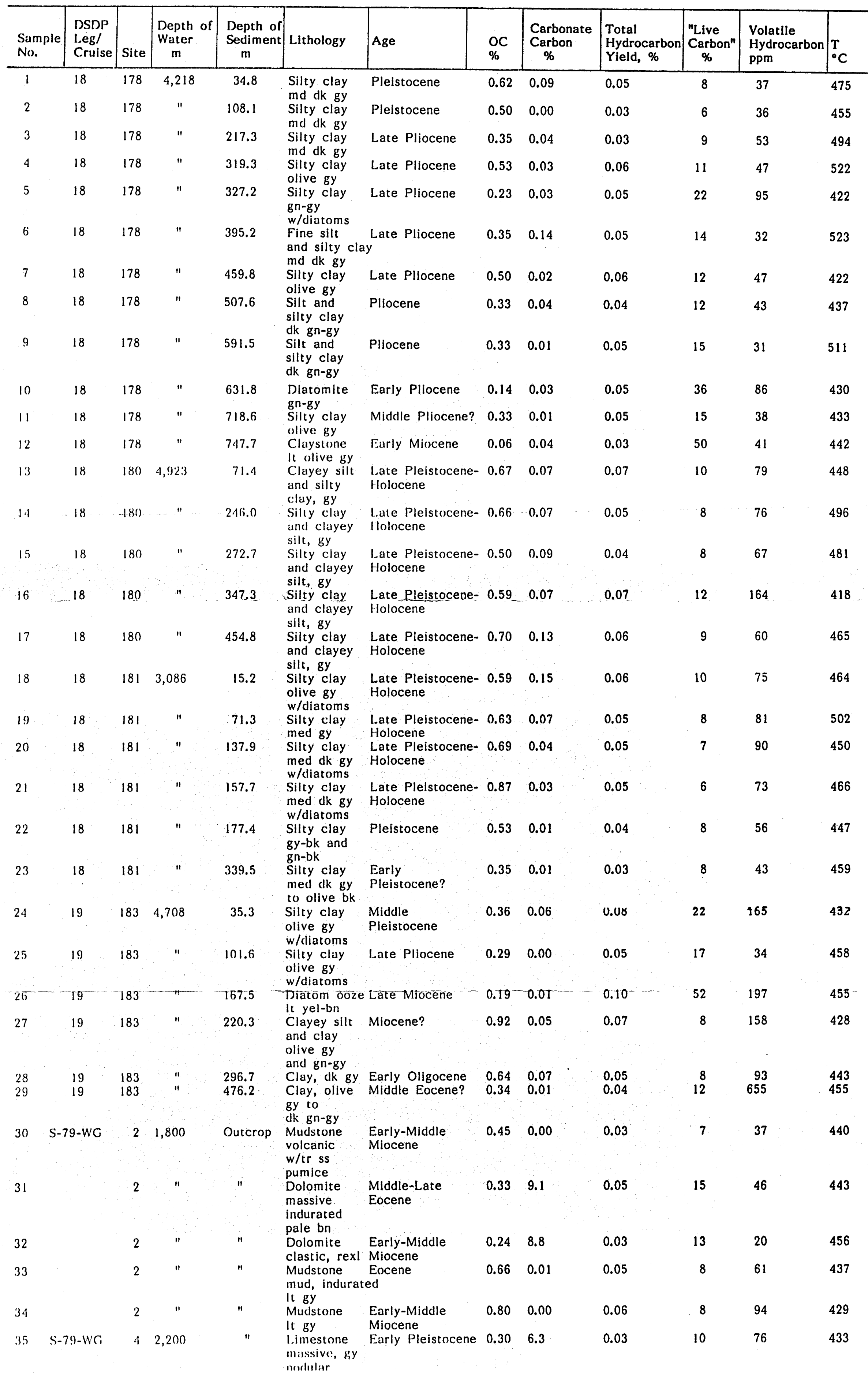




\section{SITE 178}

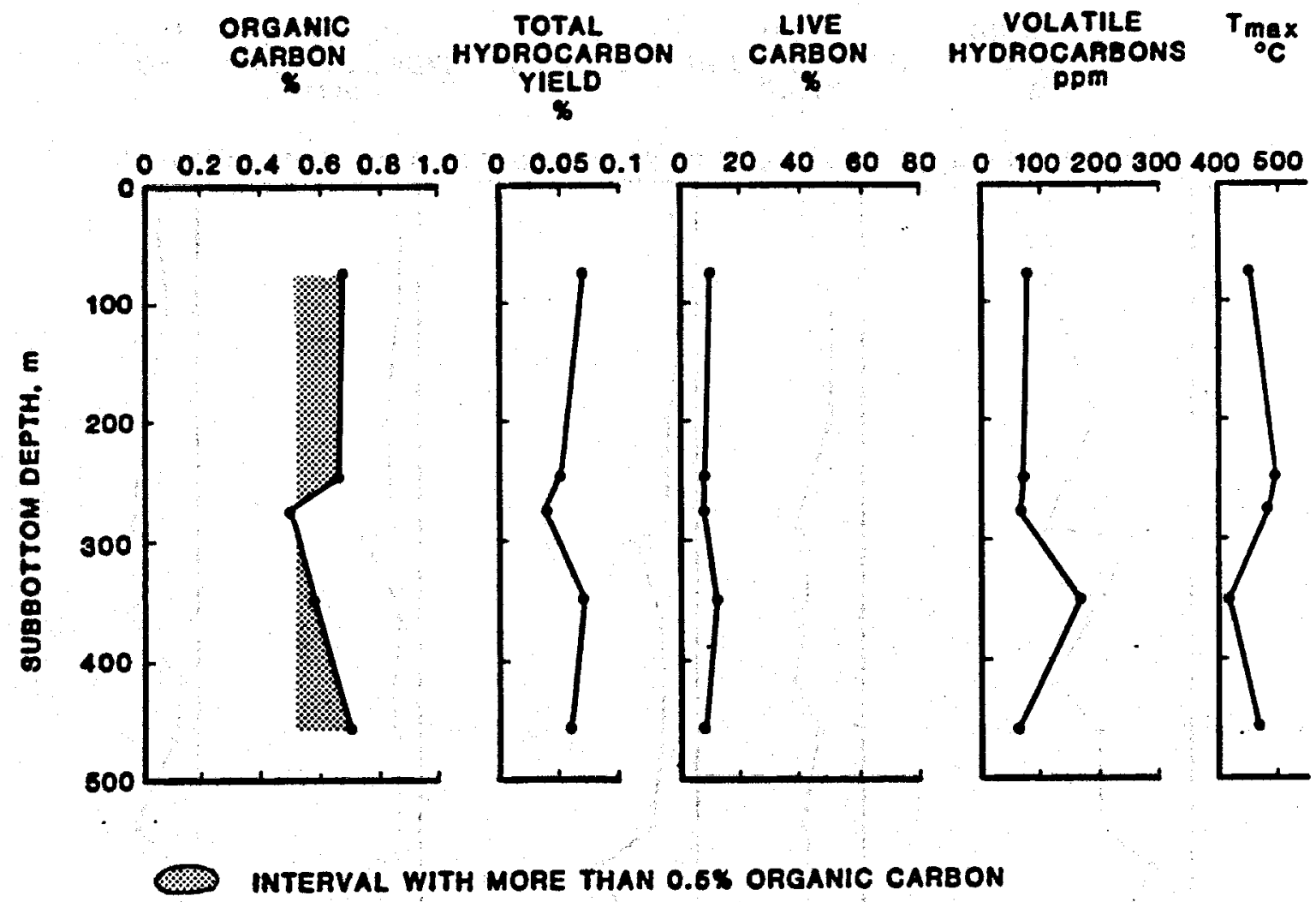

Figure 53. RESULTS OF GEOCHEMICAL ANALYSES OF SEDIMENT SAMPLES AT DSDP SITE 178, LEG 18

Modified after Kvenvolden and von Huene, 1985 


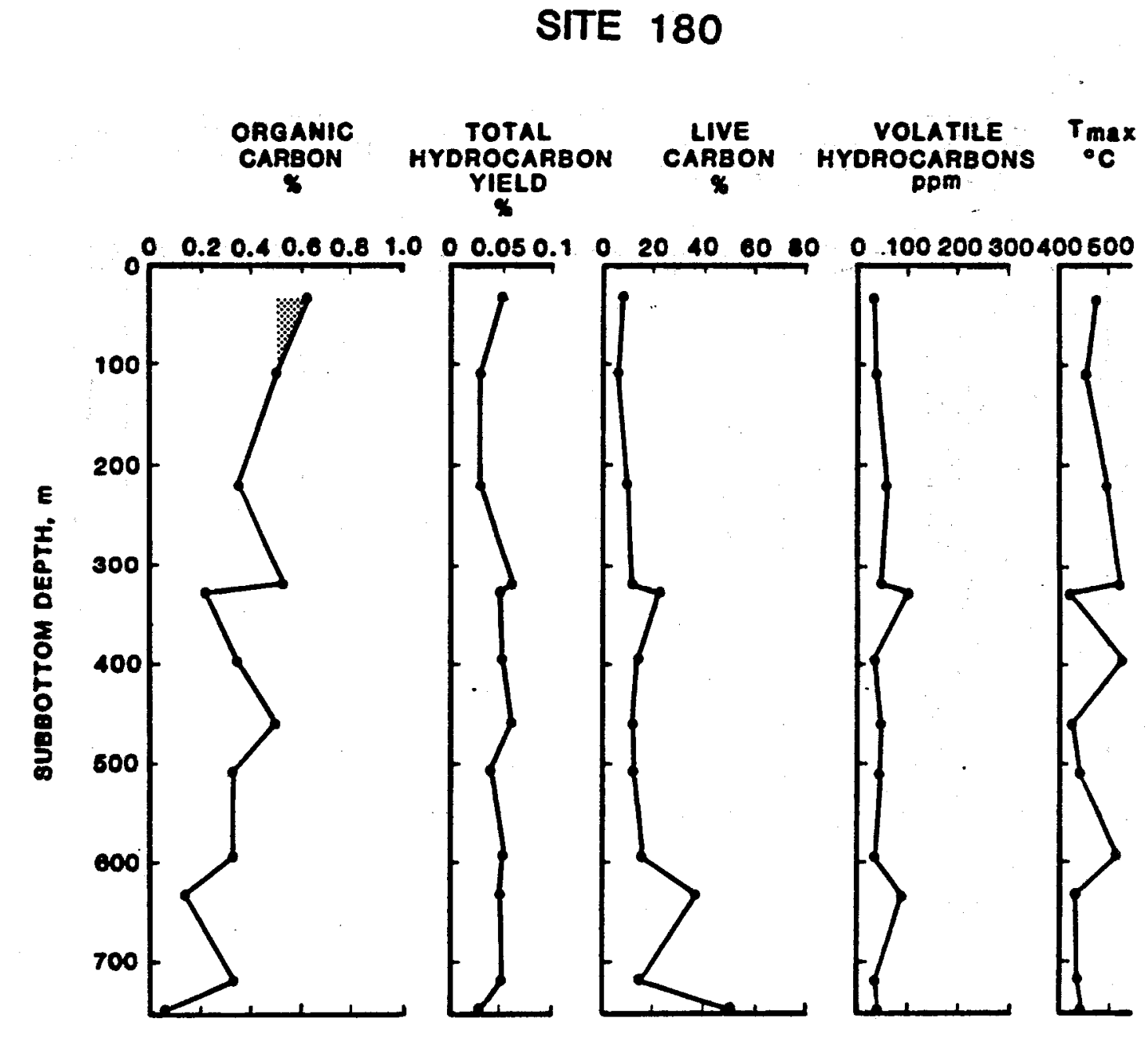

\section{SITE 180}

Inteaval WITH MORE THAN 0.5\% ORgamic CarBon

Figure 54. RESULTS OF GEOCHEMICAL ANALYSIS OF SEDIMENT SAMPLES AT DSDP SITE 178, LEG 18

Modified after Kvenvolden and von Huene, 1985 


\section{SITE 181}

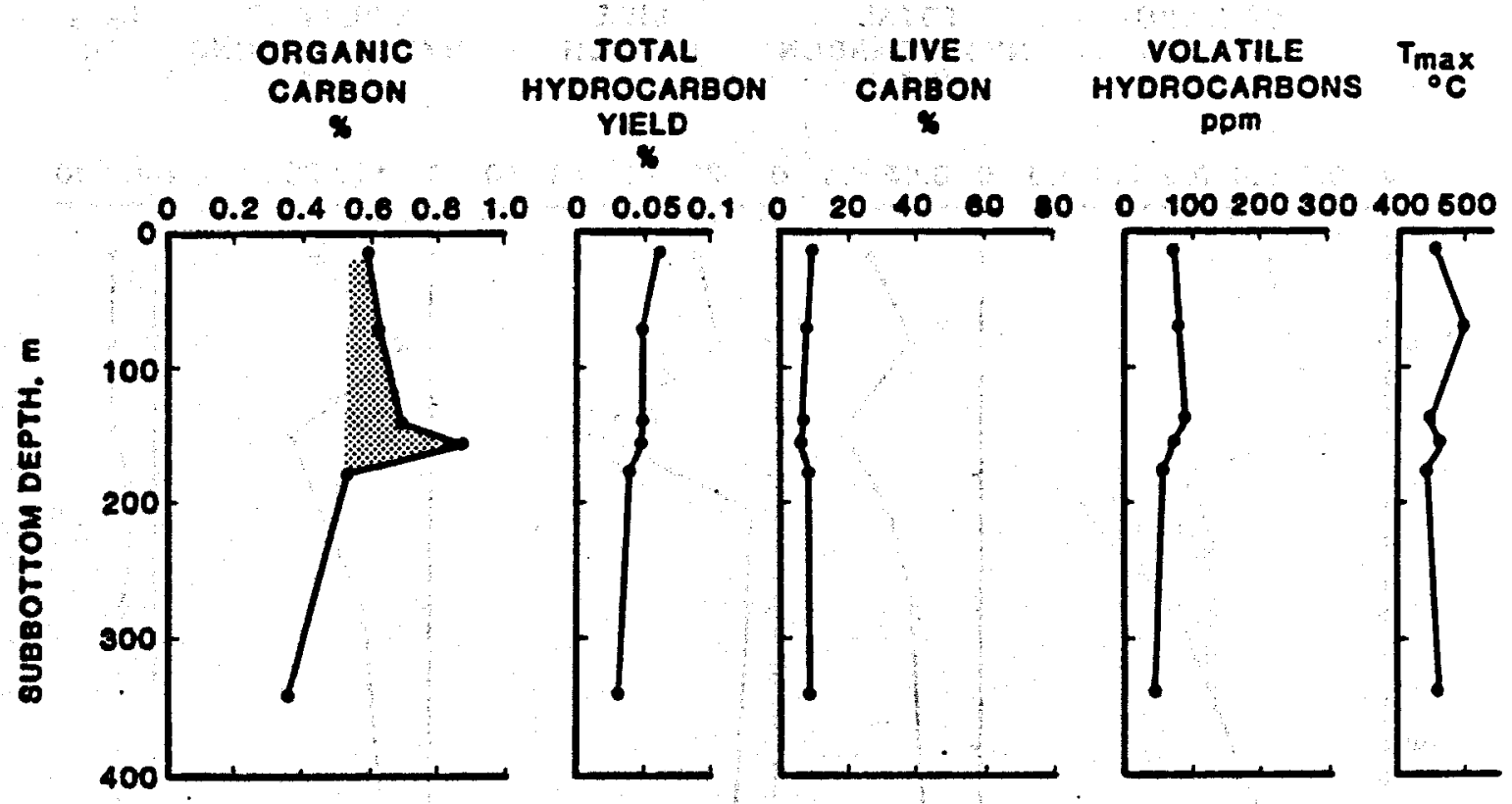

INTERVAL WITH MOAE THAN $0.6 \%$ ORGANIC CARBON

Figure 55. RESULTS OF GEOCHEMICAL ANALYSIS OF SEDIMENT SAMPLES AT DSDP SITE 181, LEG 18

Modified after Kvenvolden and von Huene, 1985 


\section{SITE 183}

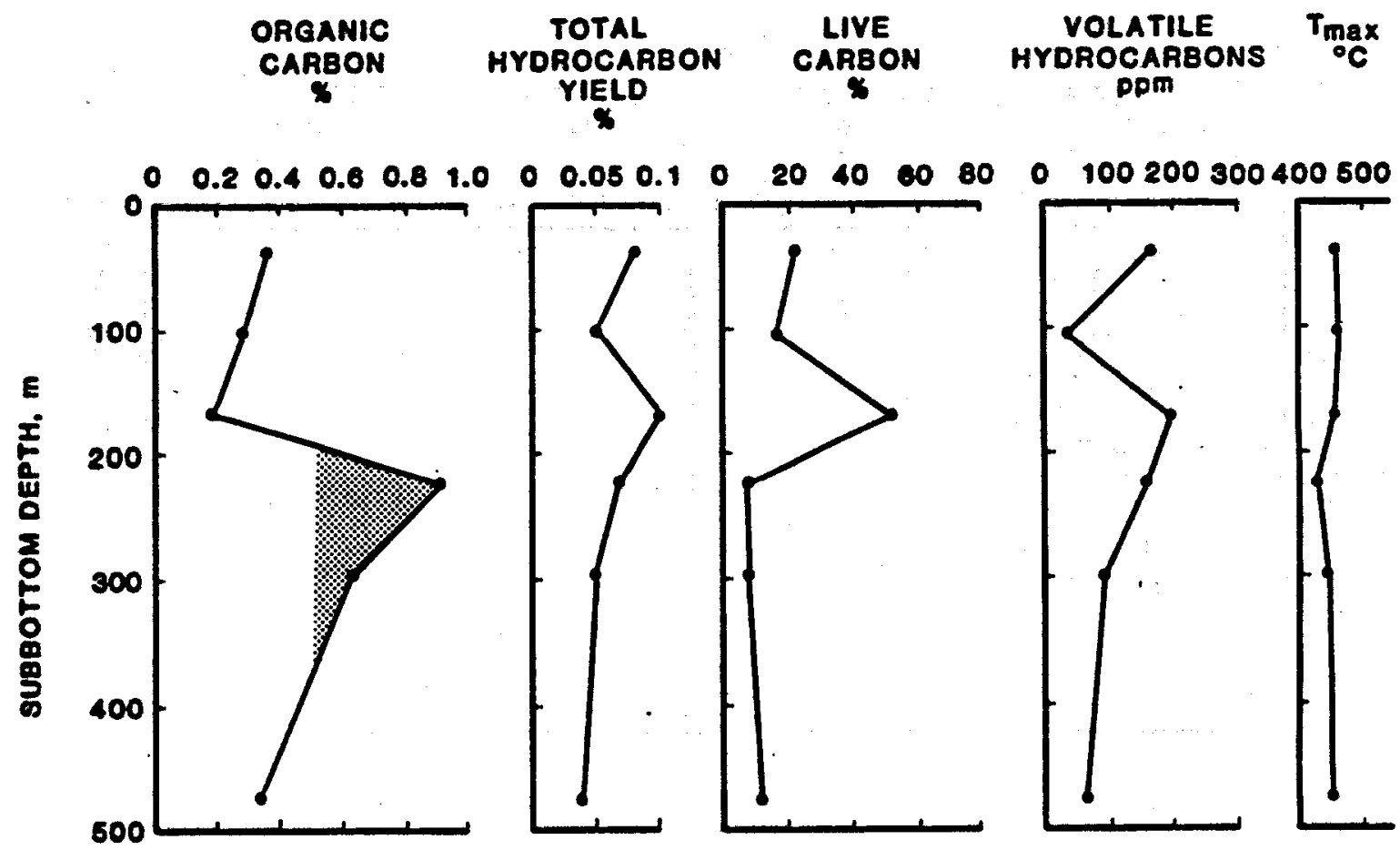

InTERVAL WITH MOAE THAN 0.6\% ORGANIC CARBON

Figure 56. RESULTS OF GEOCHEMICAL ANALYSIS OF SEDIMENT SAMPLES AT DSDP SITE 183, LEG 19

Modified after Kvenvolden and von Huene, 1985 


\section{Kerogen Analyses}

Nine of the samples listed in Table 12 were chosen for a more detailed examination of kerogen (Table 11). The scope of the examination included Rock-Eval, vitrinite reflectance $\left(R_{0}\right)$, and visual kerogen analyses. The standard pyrolysis method of source rock evaluation (Rock-Eval) was developed by Espitalite et al. (1977). The rock sample is heated up to $550^{\circ} \mathrm{C}$. In the process of pyrolysis the hydrocarbons already present in the analyzed sample are first released at moderate temperatures. These hydrocarbons are measured as $S_{1}$ by a flame ionization detector (FID). Under further increased temperature generated hydrocarbons and hydrocarbon-like compounds $\left(\mathbf{S}_{2}\right)$ are volatilized and measured by FID. Eventually, the oxygen-containing elements, i.e. carbon dioxide $\left(S_{3}\right)$ and water are measured by a thermal conductivity detector. The kerogen type is commonly characterized by two standard indices: the hydrogen index $(\mathrm{HI})$ defined as a ratio $\mathrm{S}_{2}$ /organic carbon and oxygen ratio (OI) calculated as $S_{3}$ /organic carbon. Both indices are strongly dependent on elemental composition of kerogen and correlate well with hydrogen/carbon $(\mathrm{H} / \mathrm{C})$ and oxygen/carbon $(\mathrm{O} / \mathrm{C})$ ratios respectively. For the latter reason the two pairs of ratios can be used interchangeably. Using $\mathrm{HI}$ and $\mathrm{OI}$ values, a van Krevelen diagram (Tissot and Welte, 1984) can be constructed. This diagram delineates the areas of various paths of thermal evolution of kerogen, providing its useful classification based on $H / I$ and $O / I$ relationship (Durand et al., 1972; Tissot and Welte, 1984). Various investigations showed that the evolution of kerogen is closely related to the environment of its deposition, i.e. different hydrogen:oxygen ratios. Three types of kerogen have been distinguished on the basis of Initial hydrogen carbon and oxygen contents and changes of their ratios as the kerogen evolved:

Type I kerogen has high initial $\mathrm{H} / \mathrm{C}$ ratio ( 1.5 or more) and relatively low $\mathrm{O} / \mathrm{C}$ ratio (usually smaller than 0.1 ). It is rich in aliphatic structures, 1.e. in hydrogen; some algal deposits represent this type of kerogen. During the process of pyrolysis in temperatures up to 550 to $600^{\circ} \mathrm{C}$, Type I kerogen produces more volatile and extractable compounds than any other type of kerogen.

Type II kerogen is related to the marine depositional environment. It is characterized by relatively high $\mathrm{H} / \mathrm{C}$ and $\mathrm{O} / \mathrm{C}$ ratios ranging from 0.02 to 0.2 . The organic matter is derived from a mixture of phytoplankton, zooplankton and microorganisms deposited in a reducing environment. This kerogen is a frequent constituent in many petroleum source rocks and oil shales.

Type III represents kerogen with a low initial H/C atomic ratio (less than 1.0 ) and high $O / C$ ratio (often reaching values 0.2 to 0.3 ). This type of kerogen is mainly derived from continental higher plants and contains vegetal debris. Despite the low $\mathrm{H} / \mathrm{C}$ ratios, the possibility of oil generation from this kerogen is limited. Certain economic quantities of gas can be generated if it is buried sufficiently deep.

Plotted values of $\mathrm{HI}$ and $\mathrm{OI}$ for analyzed rock samples from the eastern Aleutian Trench area are shown in Figure 57. It appears that the kerogen 


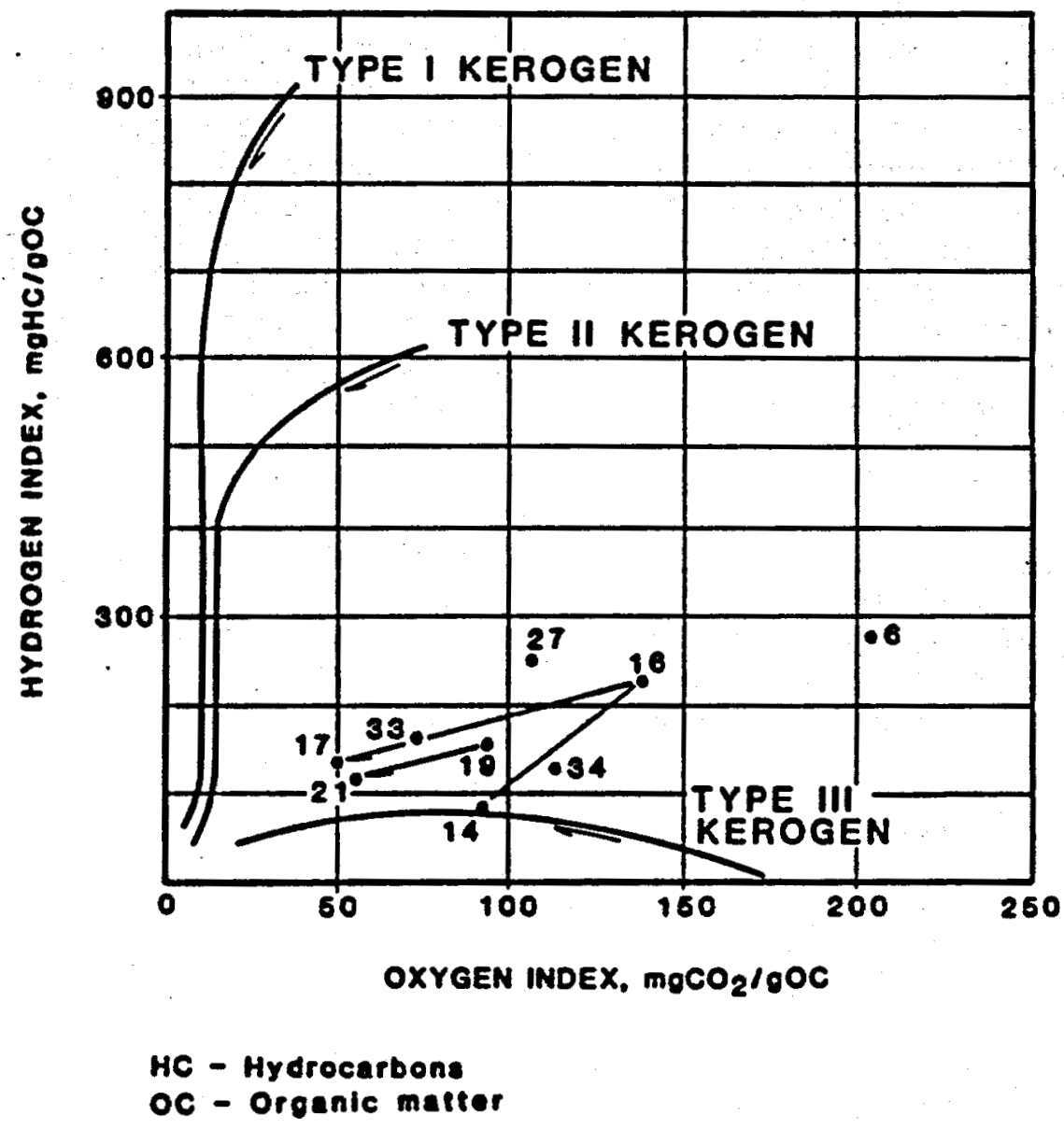

Figure 57. VAN KREVELEN DIAGRAM AND RESULTS OF GEOCHEMICAL ANALYSES OF ORGANIC MATTER ON NINE SAMPLES FROM THE ALEUTIAN TRENCH AREA

After Kvenvolden and von Huene, 1985 
occurring in these sediments is represented by Type III which has moderate to low potential for hydrocarbon gas generation. The amounts of vitrinite, exinite, and inertinite (Table 11) fit well the evolution path of Type III kerogen. Particularly the presence and relatively high content of inertinite indicates a low potential of kerogen from the eastern Aleutian Trench area and was also confirmed by values of the vitrinite reflectance $\left(R_{0}\right)$ which mostly range from 1.5 to 2.6 (Table 11). Such values of $R_{0}$ indicate immature organic matter with regard to oil and gas generation potential.

\section{Thermogenic and Biogenic Gases}

Although the available data on hydrocarbon gases from near-surface sediments seem to favor biogenic generation, several authors also advocate the thermogenic origin of gases (Claypool et al., 1973; Cline and Holmes, 1977; Kvenvolden and Field, 1981; Kvenvolden and von Huene, 1985). In view of the shallow depths at which thermogenic hydrocarbon generation may occur (Claypool et al., 1973; Grayson and La Plante, 1973), Kvenvolden and von Huene's (1985) approach including an active subduction zone of the Aleutian Trench seems to be even more reasonable. On the basis of seismic and geochemical data, the latter authors calculated that 11 TCF of thermogenic methane is generated each million years along $600 \mathrm{~km}$ of the eastern Aleutian Trench. The calculations were based on assumptions that the average thickness of sediments in the subduction zone is $3,000 \mathrm{~m}$ and subduction rate equals $60 \mathrm{~km} / \mathrm{m} . \mathrm{y}$.

The amount of available geochemical data on hydrocarbon gases in sediments of eastern Aleutian Trench area is far insufficient for the conclusive assessment of the processes generating the gas encountered at the DSDP sites (Kulm et al., 1973; Creager et al., 1973). There are, however, some arguments suggesting the biogenic provenance of these gases:

1. Data shown by Claypool et al. (1973; Table 13), McIver (1973; Table 14), and Sandstrom et al. (1983; Figure 15) indicate that methane is a predominant component in all samples.

2. The relative concentrations of hydrocarbon gases are of ten used as indicators of biogenic or thermogenic origin of gases (Barnard, 1976) The ratios $C_{1} /\left(C_{2}+C_{3}\right)$ in all gas samples from the Alaskan shelf show values below 100 when the marginal value of this ratio for thermogenic gases is often considered to be 50. Some authors pointed out that such low contents of methane may be caused by secondary processes of hydrocarbon gas alteration, l.e. ges ebullition (Martens and Berner, 1974), gas venting (Nelson et al., 1979), microbial consumption in oxidizing environments (Kvenvolden and Kaplan, 1982).

3. The presence of ethane $\left(C_{2}\right)$ and propane $\left(C_{3}\right)($ Table 15) can originate from both biogenic and thermogenic processes. Their respective ratios with ethene $\left(C_{2=}\right)$ and propene $\left(C_{3=}\right)$ showing similar values throughout the areas containing biogenic gases indicate a common source of the gas. Ethene and propene do not occur in thermogenic gases (Hunt, 1974). 
TABLE 13.

CHEMICAL AND ISOTOPIC COMPOSITION OF THE GAS SEDIMENT AT DSDP SITE 180. After Claypool et al., 1973

\begin{tabular}{|c|c|c|c|c|c|}
\hline \multirow[t]{2}{*}{ Sample } & \multirow{2}{*}{$\begin{array}{l}\text { Depth below } \\
\text { sea floor } \\
\text { m }\end{array}$} & \multicolumn{3}{|c|}{$\begin{array}{l}\text { Component } \\
\text { volume } \%\end{array}$} & \multirow{2}{*}{$\begin{array}{c}\delta_{0 / 00}^{13} \mathrm{C} \\
\mathrm{CH}_{4}\end{array}$} \\
\hline & & $\mathrm{CH}_{4}$ & $\mathrm{C}_{2} \mathrm{H}_{6}$ & $\mathrm{CO}_{2}$ & \\
\hline $\begin{array}{r}180-15 \\
17 \\
18 \\
22\end{array}$ & $\begin{array}{l}245 \\
266 \\
272 \\
441\end{array}$ & $\begin{array}{l}98.1 \\
98.1 \\
97.8 \\
99.5\end{array}$ & $\begin{array}{l}\text { n.d.* } \\
\text { n.d. } \\
\text { n.d. } \\
\text { n.d. }\end{array}$ & $\begin{array}{l}1.91 \\
1.89 \\
2.19 \\
3.11\end{array}$ & $\begin{array}{l}-75.7 \\
-76.5 \\
-72.6 \\
-80.8\end{array}$ \\
\hline
\end{tabular}

* Not determined

TABLE 14.

ORGANIC CARBON AND HYDROCARBON GAS FROM CANNED CORE SAMPLES IN DSDP SITE 180. After Mclver, 1973.

\begin{tabular}{c|c|c|c|c|c}
\hline Core & Section & $\begin{array}{c}\text { Subbottom } \\
\text { depth } \\
m\end{array}$ & $\begin{array}{c}\text { Organic } \\
\text { carbon } \\
\%\end{array}$ & $\begin{array}{c}\text { Hydrocarbon } \\
\text { gas } \\
\text { ppm by vol. }\end{array}$ & $\begin{array}{c}\text { Methane } \\
\text { in hydrocarbon } \\
\text { gas } \\
\%\end{array}$ \\
\hline
\end{tabular}

\begin{tabular}{rrrrrr}
12 & 2 & 150 & 0.16 & 2,100 & $98.7^{* *}$ \\
12 & 2 & 150 & 0.16 & 1,700 & $98.3^{* *}$ \\
15 & 3 & 250 & N/A* & 600 & $96.5^{* *}$ \\
18 & 1 & 271 & 0.30 & 1,400 & 99.8 \\
18 & 1 & 271 & 0.24 & 11,600 & 100.0 \\
18 & 4 & 279 & N/A & 42,800 & 100.0 \\
20 & 5 & 420 & N/A & 55,700 & 100.0 \\
24 & 3 & 456 & 0.43 & 1,500 & 99.9 \\
24 & 3 & 456 & 0.43 & 200 & 99.5 \\
\hline
\end{tabular}

* N/A Not analyzed

* Low values of total gas caused significant drop in methane percentage whenever traces of ethane were present. 
TABLE 15.

MEDIAN HYDROCARBON GAS CONCENTRATIONS AND GAS RATIOS*. After Sandstrom et al., 1983

\begin{tabular}{l|c|c|c|c|c|c}
\hline Analyte & $\begin{array}{c}\text { Beaufort } \\
\text { Sea }\end{array}$ & $\begin{array}{c}\text { Bering } \\
\text { Sea }\end{array}$ & $\begin{array}{c}\text { Cook } \\
\text { Inlet }\end{array}$ & $\begin{array}{c}\text { Kodiak } \\
\text { Shelf }\end{array}$ & $\begin{array}{l}\text { Norton } \\
\text { Sound }\end{array}$ & $\begin{array}{c}\text { Norton Sound } \\
\text { Vibracores }\end{array}$ \\
\hline$C_{1}$ & 2.11 & 1.69 & 1.66 & 4.72 & 2.51 & 64.15 \\
$C_{2}$ & 0.14 & 0.08 & 0.08 & 0.10 & 0.11 & 0.12 \\
$C_{211}$ & 0.29 & 0.11 & 0.14 & 0.15 & 0.18 & 0.08 \\
$C_{3}$ & 0.08 & 0.07 & 0.05 & 0.09 & 0.10 & 0.19 \\
$C_{3: 1}$ & 0.11 & 0.06 & 0.03 & 0.04 & 0.05 & 0.05 \\
$n-C_{4}$ & 0.02 & 0.04 & 0.02 & 0.04 & 0.03 & 0.07 \\
$1-C_{4}$ & 0.01 & 0.02 & 0.01 & 0.01 & 0.02 & 0.03 \\
$C_{1} / C_{2}-C_{3}$ & 8.58 & 10.30 & 18.39 & 19.50 & 13.62 & 138.30 \\
$C_{2} / C_{2: 1}$ & 0.56 & 0.75 & 0.59 & 0.75 & 0.58 & 1.86 \\
$C_{3} / C_{3: 1}$ & 0.81 & 1.38 & 2.00 & 2.26 & 1.80 & 2.20 \\
$C_{2} / C_{3}$ & 1.60 & 1.00 & 1.41 & 1.11 & 1.00 & 0.64 \\
$C_{2: 1} / C_{3: 1}$ & 2.33 & 2.10 & 4.52 & 3.73 & 3.14 & 2.00 \\
$C_{1} / C_{1}-C_{4}$ & 0.77 & 0.82 & 0.86 & 0.91 & 0.86 & 0.99 \\
\hline
\end{tabular}

* The gas concentrations are given in parts per billion (ppb), 1.e. $10^{-9}$ $\mathrm{g} / \mathrm{g}$ of dry sediment. 
4. The issotopic data from methane analyses at DSDP Site 180 show values of $\delta^{13}$ ranging from -72.5 to -80.8 (Table 13; Claypool et al., 1973). Such $\delta^{13} \mathrm{C}$ values are commonly referred to as representing hydrocarbon gases of biogenic origin.

\section{Geothermal Gradient}

The eastern Aleutian Trench-Arc system area is inadequately documented with regard to the geothermal regime. In fact there are probably some subareas with varying geothermal gradients due to tectonic diversification of the area, as some authors suggested (Claypool et al., 1973; Lachenbruch and Sass, 1980). The only direct measurements of the formation temperature have been taken from a drill hole offshore of Middleton Island. Structurally the well was located on the edge of the shelf. The average temperature gradient was found to be $2.8^{\circ} \mathrm{C} / 100 \mathrm{~m}\left(1.42^{\circ} \mathrm{F} / 100 \mathrm{ft}\right)$. Other methods of geothermal gradients assessment involved seismically derived bottom simulating reflectors (BSRs) mostly considered as lower boundary or gas hydrates. This boundary closely related to specific temperature was first successfully used in calculating geothermal gradients by Yamano et al. (1982) in several areas of active convergent margins. The- latter method must be applied cautiously as its precision may vary due to several factors among which the most important are:

1. Gas hydrate stability curve can vary because of various gas composition, water salinity, degree of water saturation in gas, lithology, and porosity of sediments, etc.

2. Seismic velocities may alter significantly the calculations of depth of BSRs.

According to MacLeod (1982) who used BSRs, the average geothermal gradient in sediments of the Gulf of Alaska varies from 2.50 to $3.13^{\circ} \mathrm{C} / 100 \mathrm{~m}(1.37$ to $1.71^{\circ} \mathrm{F} / 100 \mathrm{ft}$ ). Kvenvolden and von Huene (1985) published their geothermal gradient estimates based on BSRs from the upper continental slopes north of the eastern Aleutian Trench and bottom sea temperatures ranging from 1 to $3^{\circ} \mathrm{C}$. The calculated values of geothermal gradients range from 2.78 to $3.5^{\circ} \mathrm{C} / 100 \mathrm{~m}\left(1.52\right.$ to $\left.1.92^{\circ} \mathrm{F} / 100 \mathrm{ft}\right)$.

Thus, the geothermal gradient across the eastern Aleutian Trench-Arc system exhibits a progressive increase from the shelf area of Middleton Island $\left(2.8^{\circ} \mathrm{C} / 100 \mathrm{~m}\right)$ through the upper continental slope $\left(\sim 3.14^{\circ} \mathrm{C} / 100 \mathrm{~m}\right)$ to approximately $2.81^{\circ} \mathrm{C} / 100 \mathrm{~m}$ in the Gulf of Alaska. Such a distribution of geothermal gradients appears to be in general agreement with those authors who advocated the idea that cool oceanic crust lowers the formation temperature in subduction zones (Lachenbruch and Sass, 1980). 


\section{PART II}

\section{FORMATION AND STABILITY OF GAS HYDRATES}

Proper understanding of the principal geological factors is critical in the determination of the formation and stability of gas hydrates. Among these factors, the thermal and pressure conditions, together with the availability of gas(es) in a free state, are the most important.

At the present time gathering of indirect and direct evidence on the gas hydrates occurrences constitutes the major objectives of these studies. Such efforts should result in the delineation of areal extent of potential zones with gas hydrates.

In the four study areas, which are the main subject of this report, no direct evidence of gas hydrates has been obtained. All these areas are insufficiently documented with geochemical data directly related to gas hydrates. Therefore, seismic evidence on gas hydrate occurrences jointly with relevant known aspects of basins' analytical data have been used in this study.

The seismic bottom simulating reflectors (BSR) are commonly used as indirect evidence of gas hydrate presence. These anomalous reflectors require careful analysis particularly in the Bering Sea shelf where BSRs similar to gas hydrates were formed as a result of diagenetic processes in diatomaceous rocks. Thus, the distinctive features of the two types of BSRs seem to be an important Issue in the initial assessment of gas hydrates.

\section{Bottom Simulating Reflectors Related to Gas Hydrates}

Seismically derived bottom simulating reflectors (BSR) are being considered as indirect evidence of gas hydrate presence and are thought to delineate the contact between the hydrate zone and underlying zone saturated with hydrocarbon gas (Stoll et al., 1971; Ewing and Holister, 1972; Dillon et al., 1980; Kvenvolden and McMenamin, 1980). Since BSR occurrence is strongly dependent on temperature, their most apparent features include a time transgressive nature and concordance with the sea-floor. Numerous investigations of BSRs in various continental margins showed BSRs coincident with the field of hydrate stability (Tucholke, 1977). Further evidence on the relationship between BSRs and gas hydrates has been obtained from the investigations of seismic velocities in sediments containing these anomalous reflectors. Lancelot and Ewing (1972) determined an apparent acoustic velocity in sediments above BSRs to be about $2,000 \mathrm{~m} / \mathrm{s}$. Independent experimental sonobuoy measurements by Bryan (1974) confirmed the findings of Lancelot and Ewing (1972) revealing unusually high acoustic velocities in presumed gas hydrate 
zones, compared with hemipelagic sediments devoid of gas hydrates. According to Halleck's (1982) laboratory experiments acoustic velocities in ocean floor sediments totally saturated with gas hydrates may increase to $2,800 \mathrm{~m} / \mathrm{s}$. Such a velocity increase is approximately $55 \%$ higher than in water saturated sediments. The increase in acoustic velocities in gas hydrate zones mostly depends on such parameters as:

1. porosity,

2. density of matrix, and

3. degree of filling of the pore space with gas hydrate.

All of these factors affect the quality of the anomalous reflectors. Bryan (1974) noted that gas hydrate related BSRs may not be readily discernible on seismic sections unless gas saturated horizons underlie a gas hydrate zone. The investigations by Paull and Dillon (1981) on changes of acoustic velocities above and beneath the BSRs seem to confirm that the large impedance contrast requires gas saturated sediment under the gas hydrate zone.

Among various criteria which discriminate the seismic responses caused by gas hydrate presence from other unusual responses, Bryan (1974) and Shipley et al. (1979) proposed:

1. reflection polarity reversal,

2. large reflection coefficient change, and

3. increased subbottom depth of the BSR with sea depth.

The first two parameters integrate changes in formation density and acoustic velocities due to the presence of gas hydrates. Reflection polarity reversal was found to be associated with the anomalous seismic reflections in the Black Outer Ridge where gas hydrates were recovered. The latter parameter may therefore be considered as an indicator of possible gas hydrate occurrence. The reflection coefficient $\left(R_{c}\right)$ has been defined, Bryan (1974), as:

$$
R_{c}=\left(\xi_{2} V_{2}-\xi_{1} v_{1}\right) /\left(\xi_{1} V_{1}+\xi_{2} V_{2}\right)
$$

where

$R_{c}=$ reflection coefficient

$\xi_{1}=$ formation density in gas hydrate zone

$q_{2}=$ formation density in free gas zone

$q_{1}=$ acoustic velocity in the hydrate zone

$V_{2}^{1}=$ acoustic velocity below the free hydrate zone.

The value of $R_{c}$ enables thus to quantify the magnitude of change of acoustic properties between hydrate and non-hydrate zones.

Although the two criteria described above cannot be considered as the ultimate indicators of gas hydrate presence, they should be utilized in a complex of other data (e.g. geothermal gradient, geochemistry of pore fluids, in-situ sampling).

- Increased subbottom depth of BSRs with sea depth has been suggested by Shipley et al. (1979) as the most important seismic criterion for the identification of gas hydrates. 


\section{Diagenetic Bottom Simulating Reflectors}

Although BSRs are generally related to gas hydrates, relatively similar reflectors may result from diagenetic processes in the marine sediments. The similar and "deceitful" nature of the latter seismic responses is caused by the fact that this particular type of diagenesis is controlled by temperature. It is therefore important to be aware of the diagenetic processes of transformation of opal-A into opal-CT which may lead to the formation of a diagenetic BSR in order to be able to distinguish both types of anomalous reflectors.

The BSRs of diagenetic origin were first noted by Scholl and Creager (1973) during Deep Sea. Drilling Project Leg 19 in the area of the Umnak Plateau in the southern Bering Sea. In general, the lithostratigraphic profiles in this area consist of diatom ooze and diatomaceous mudstone overlaying terrigenous mudstone beds. Analyses of rock samples from DSDP sites of Leg 19 revealed that BSRs regionally ubiquitous in the Bering Sea and northern Pacific regions coincide with beds of silica-cemented mudstone and porcelanite. In mineralogical terms the process of diagenetic sediment transformation resulting in the formation of BSRs is considered frequently as the transition of biogenic opal-A into opal-CT (Hein et al., 1978). While opal-A is a commonly used term for biogenic silica, the term opal-CT is variably defined as disordered, interlayered, $\alpha$-cristobalite, and $\alpha$-trymidite (Florke, 1955; Jones and Segnit, 1971), crystals of trymidite (Ochler, 1973) or as disordered -trymidite (Wilson et al., 1974). In the process of diagenetic transformation, during the first $300-400 \mathrm{~m}$ of burial, diatom frustules are fragmented and undergo mild dissolution. The dissolved biogenic silica reprecipitates at a greater depth $(600-700 \mathrm{~m})$ as inorganic opal-A which in turn is rapidly transformed into opal-CT (Hein et al., 1970). Progressive changes of opal-A to opal-CT can be observed on X-ray diffractograms (Figure 58) which well illustrate the sequence of changes described above after Hein et al. (1978). Although the presence of opal-CT is mostly attributed to diagenetic transformation of biogenic silica some authors expressed views that similar opal-CT could result from alteration of volcanic debris (Mattson and Pessagno, 1971; Griffin et al., 1972).

\section{Navarin Basin}

The identification of BSRs is greatly facilitated in areas of deformed sediments due to the time transgressive nature of these seismic reflectors. Conversely, BSRs may not be readily discernible where they are parallel to sediment stratification reflectors. A typical seismic line from the proximity of NB COST 1 well is shown in Figure 59. This seismic line illustrates that the lack of dipping reflectors in the Navarin Basin precludes the presence of distinct bottom simulating reflectors. There is however at $1.27 \mathrm{~s}$ depth (i.e. $1,085 \mathrm{~m}$ ) below sea-level, a strong reflector which colncides with horizon $A$ in NB COST 1 well (Turner et al., 1984) showing features of a BSR. Although relatively large amounts of $\mathrm{CH}_{4}$ were found to the depth of $1,830 \mathrm{~m}(6,000$ $\mathrm{ft}$ ) in the profile of NB COST 1 well, the BSR does not seem to be related to gas hydrates. The most important argument for the non-hydrate origin of this anomalous reflector is the measured values of temperature and pressure $\left(54.4^{\circ} \mathrm{C}\right.$ and 124 atm respectively) which are well outside of the gas hydrate 


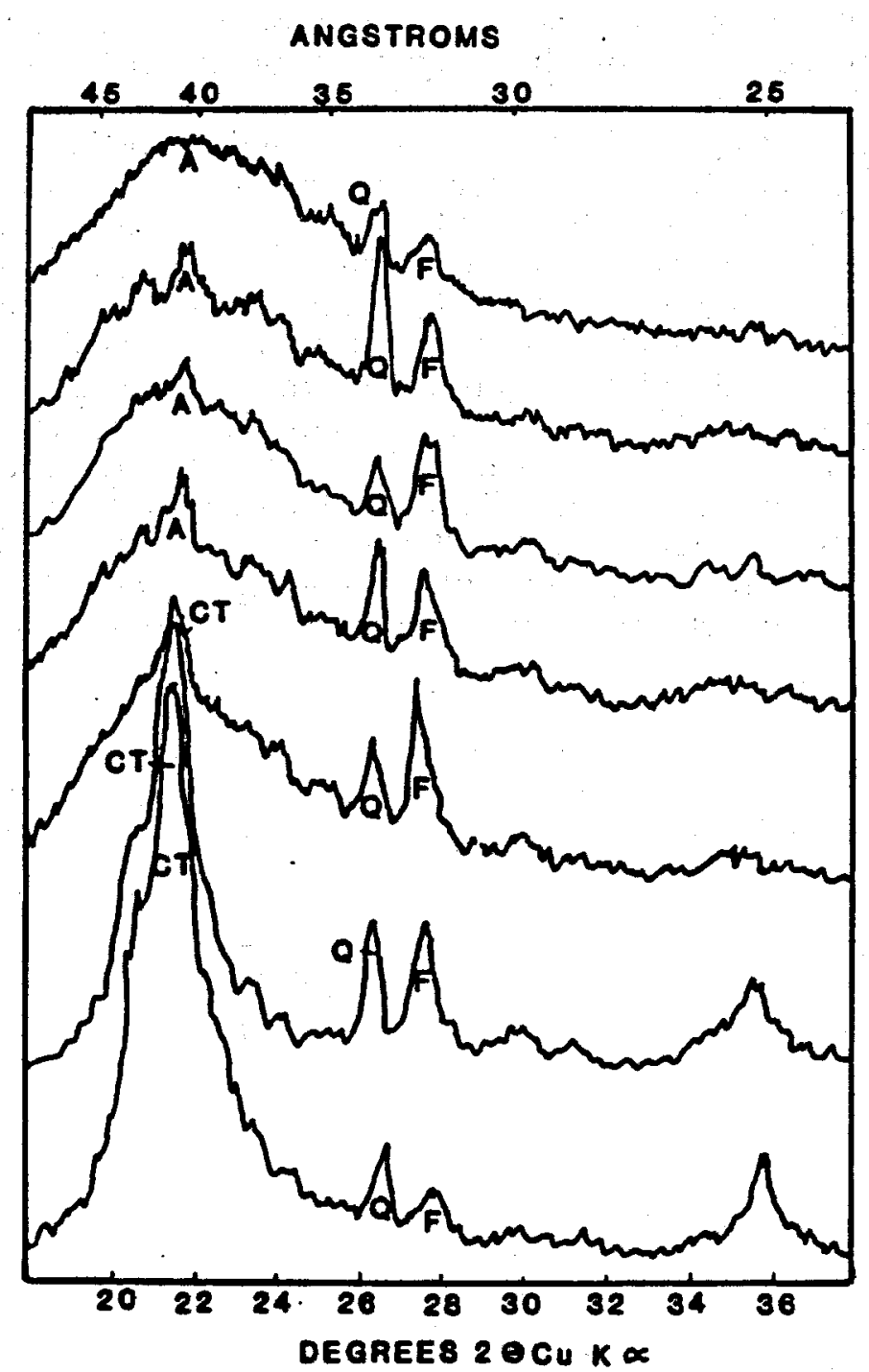

Figure 58. X-RAY DIFFRACTOGRAMS SHOWING PROGRESSIVE TRANSFORMATION OF BIOGENIC OPAL-A INTO OPAL-CT IN SEDIMENTS AT THE DSDP 188 After Hein et al., 1878 


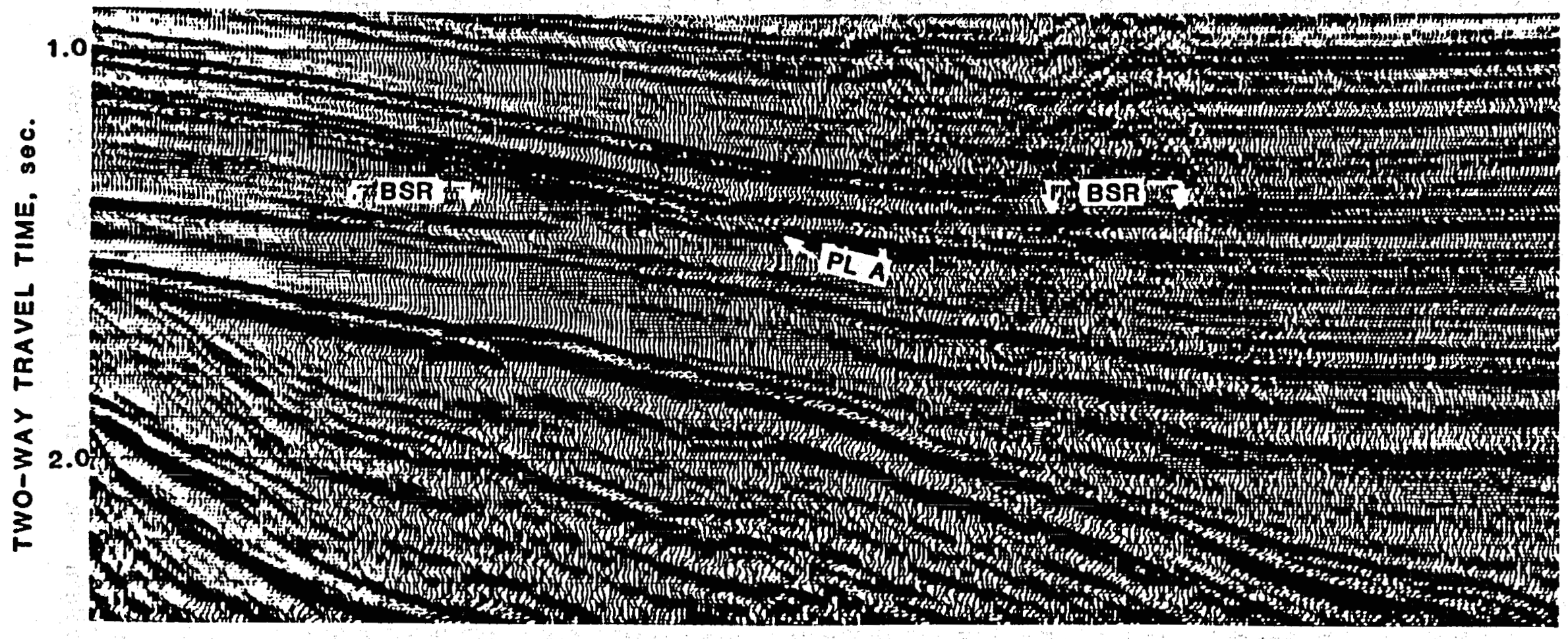

Figure 59. SEISMIC REFLECTION PROFILE CROSSING THE AREA IN VICINITY OF THE NAVARIN BASIN COST NO. 1 WELL

After Turner et al., 1984 
stability field (e.g. maximum marginal temperature for methane hydrate is equal to $17.2^{\circ} \mathrm{C}$ ). Seismic horizon $A$ and the coinciding BSR represent a paleontologically barren zone which probably resulted from the dissolution of most siliceous and calcareous microfossils. The recrystallization of silica in the form of opal-CT produced a zone of abruptly changed physical properties among which a decrease of porosity and increase of bulk density and related transit time of acoustic waves (Figures 60 and 61 ) are the most apparent. Diatoms, which are the main source of silica, constitute 50 to $80 \%$ of the sediment in the upper $1,130 \mathrm{~m}(3,700 \mathrm{ft})$ in the NB COST 1 well. According to Hein et al. (1978), burial of at least $500 \mathrm{~m}(1,640 \mathrm{ft})$ and a temperature range of $35^{\circ}$ to $51^{\circ} \mathrm{C}\left(95^{\circ}\right.$ to $\left.125^{\circ} \mathrm{F}\right)$ are necessary to initiate a rapid conversion of opal-A to opal-CT. Both of these conditions are met at the depth of the BSR in the profile; considering thermal control of dissolution and precipitation of opal, Scholl and Creager (1973), Fullam et al. (1973), and Hein et al. (1978) suggested that the ubiquitous time transgressive bottom simulating reflector in the Bering Sea represents a diagenetic zone of opal-CT and clinoptilolite.

Although no gas hydrate related BSRs were found within the Navarin Basin, few seismic reflection records from the continental slope west of this area show a presence of BSRs which can be attributed to gas hydrate, independently from the BSRs caused by the diagenetic boundary (Marlow et al., 1981). Some examples of simultaneous occurrence of the two types of BSRs are shown in Figures 63, 64, and 65. Contrary to diagenetic BSRs, the gas hydrate related anomalous reflectors appear to be weak and are mostly discernible in areas of diversified sea bottom relief with undeformed sediment cover (Figures 63 and 64). The subbottom depth of BSRs associated with gas hydrates in the continental slope west of the Navarin Basin range from $i$ sec. (seismic line B 99) to $0.4 \mathrm{sec}$ (seismic line L 4) two-way travel time. Sea water depths along these seismic sections containing BSRs, assumed to be gas hydrate related, exceed $500 \mathrm{~m}$ (Figure 62). The deepest subbottom BSR seems to occur along profile L 13 (Figure 64) where the sea-floor lies at about 2,800 $\mathrm{m}$. Other features of these BSRs include excessively high acoustic velocity above them compared with typical sediment, negative phase of reflectors and relatively low reflection coefficient. All these features of the presented BSRs seem to confirm the occurrence of gas hydrates stabilized on the middle and upper continental slope west of the Navarin Basin. Because of the existing structural pattern, they are not often readily identifiable. On the other hand, analyses of surface sediments in the area of the Navarin Basin outer margin (Marlow et al., 1981; Kvenvolden and Reddon, 1980) show low concentrations of hydrocarbon gases in the upper 1-2 $\mathrm{m}$ beneath the sea floor.

The relatively poor prognosis for hydrocarbon generation in the Navarin Basin provides at least partial explanation for the weak and discontinuous nature of the BSRs. As the BSRs alone cannot be used for the assessment of the gas hydrates, specialized geochemical investigations and a seismic survey are needed especially in the area of the upper continental slope.

\section{Norton Basin}

Listing of the Norton Basin among 24 , sites worldwide with probable gas hydrate occurrences was based on anomalous seismic reflectors identified by Mousseau (Kvenvolden and Barnard, 1983). Our review of the available 
INTERVAL TRANSIT TIME, microseconds/foot

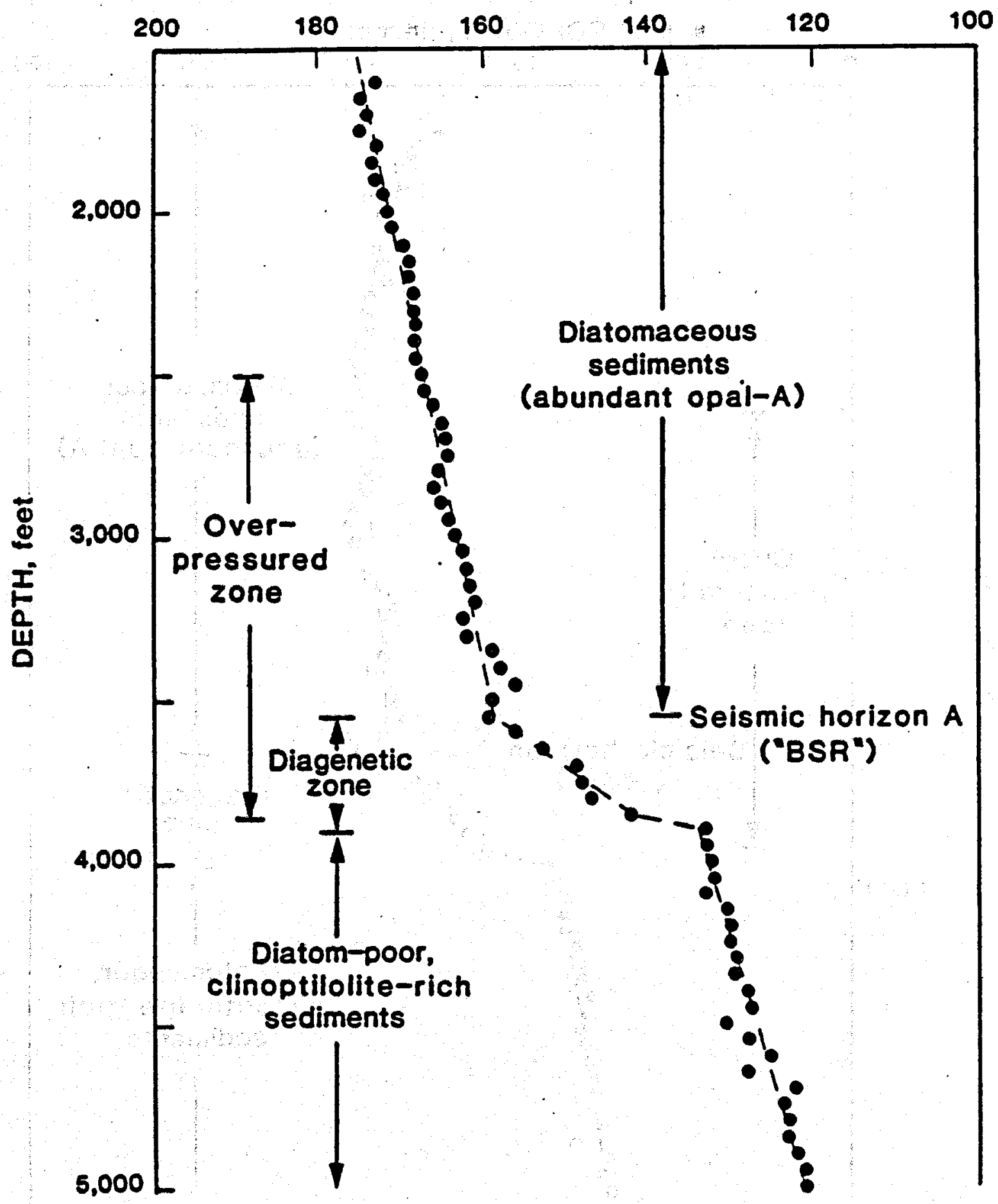

Figure 60. ANOMALOUS CHANGES OF INTERVAL TRANSIT TIME IN THE DIAGENETIC ZONE, NAVARIN BASIN COST NO. 1 WELL 


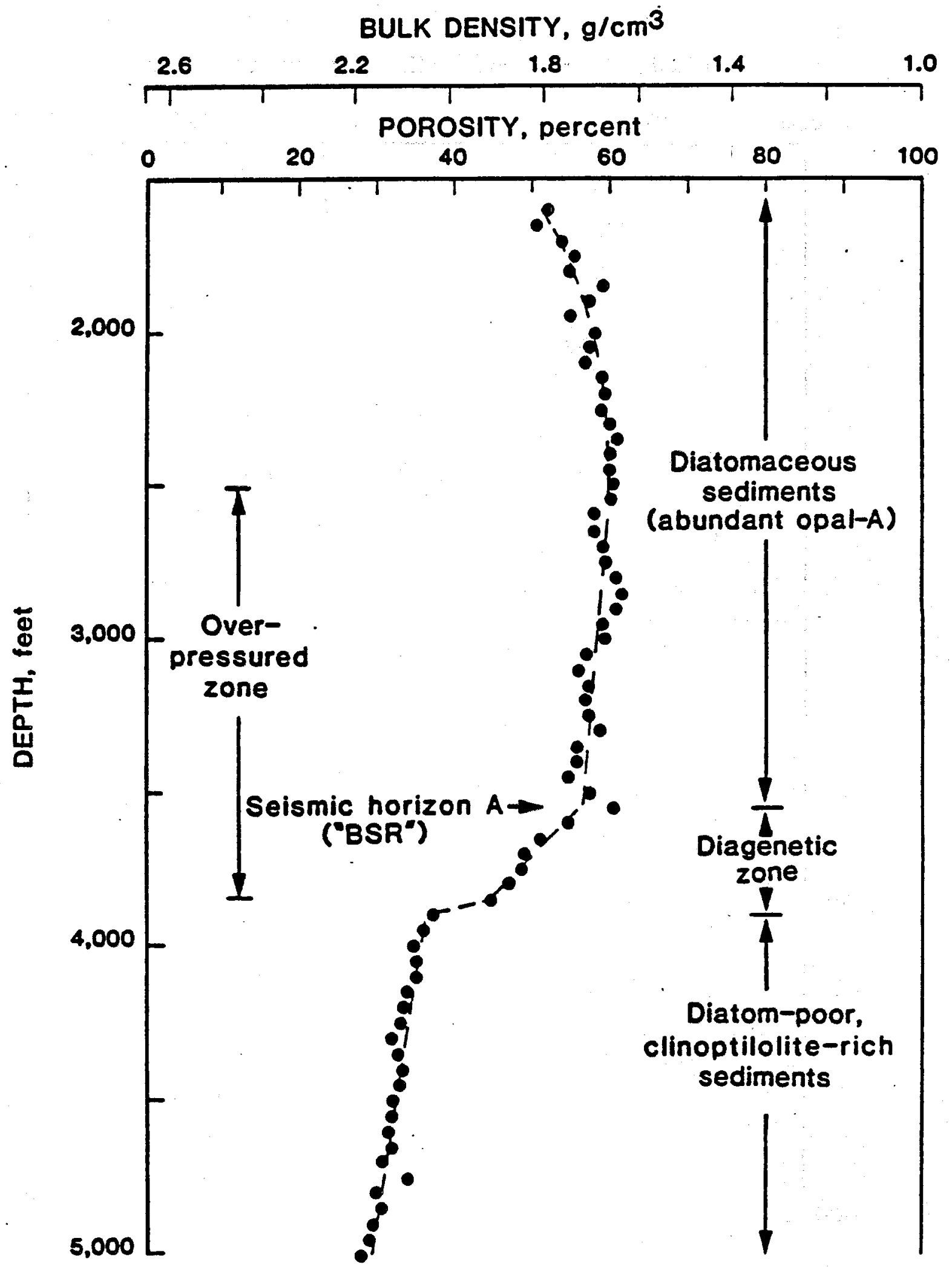

Figure 61. CHANGES OF POROSITY AND BULK DENSITY OF DIATOMACEOUS SEDIMENTS IN THE NAVARIN BASIN COST NO. 1 WELL 


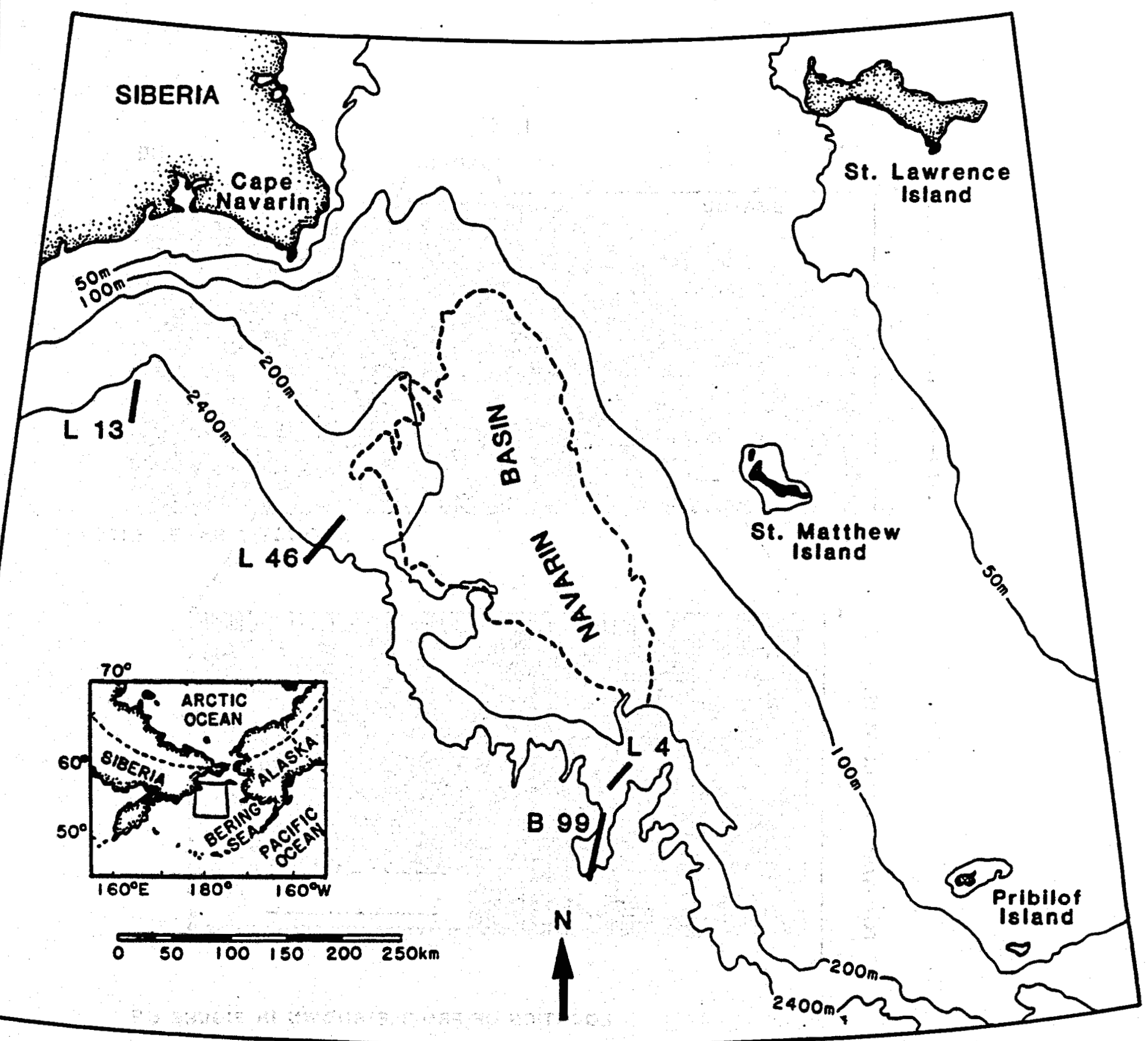

Figure 62. LOCATION OF SEISMIC LINES SHOWN IN FIGURES $63,64,65$ 


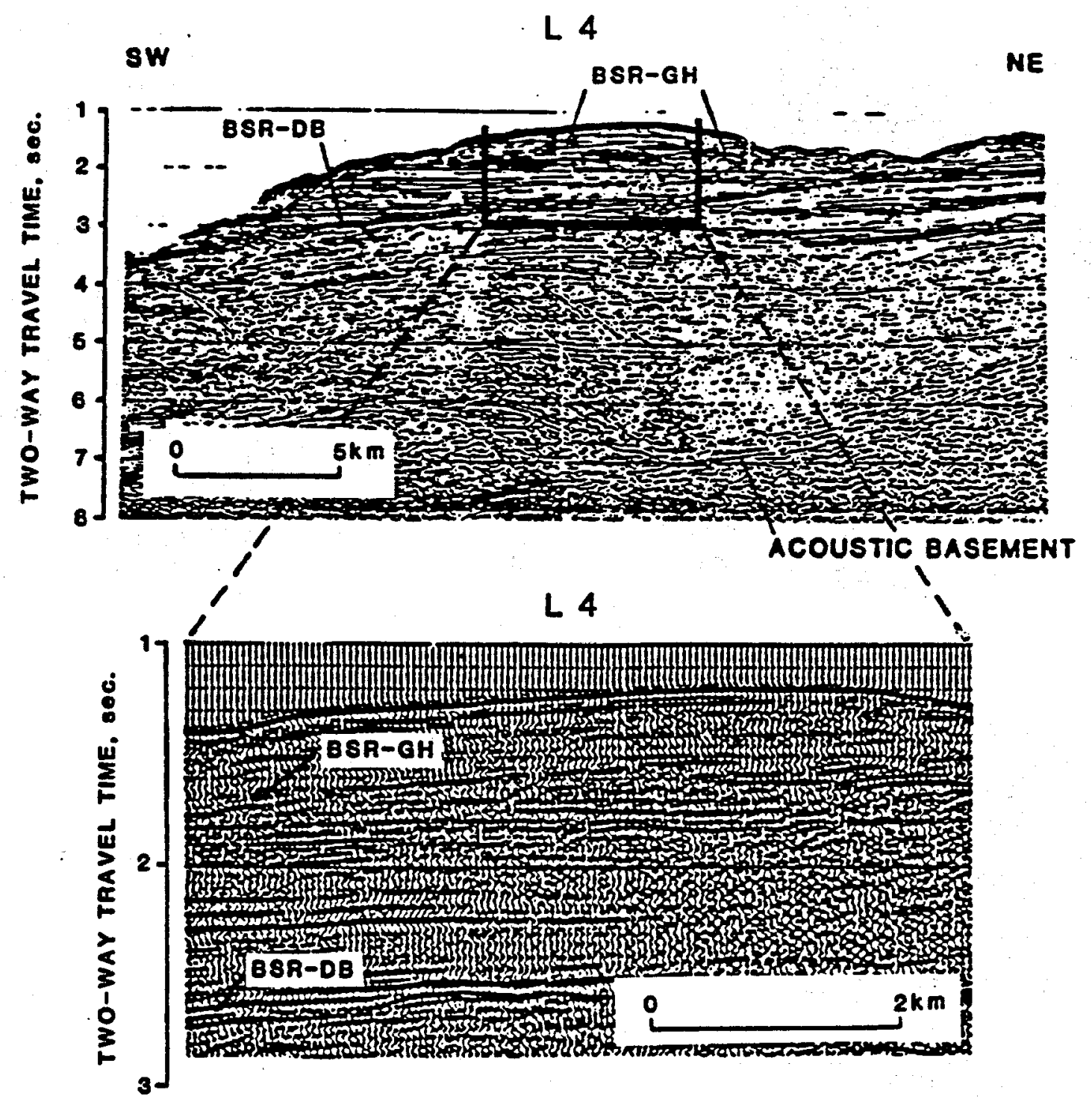

LOCATION OF PROFILEYSHOWN IN FIGURE 62

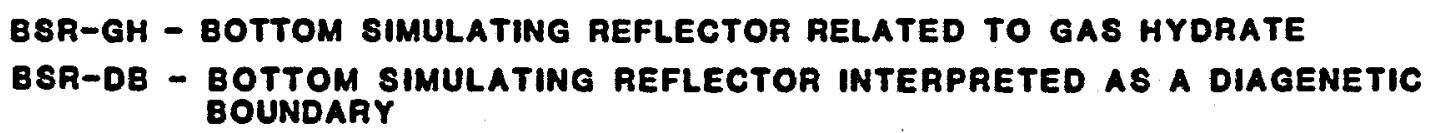

Figure 63. SEISMIC LINE FROM THE NAVARIN BASIN REGION After Marlow et al., 1981 


\section{46}

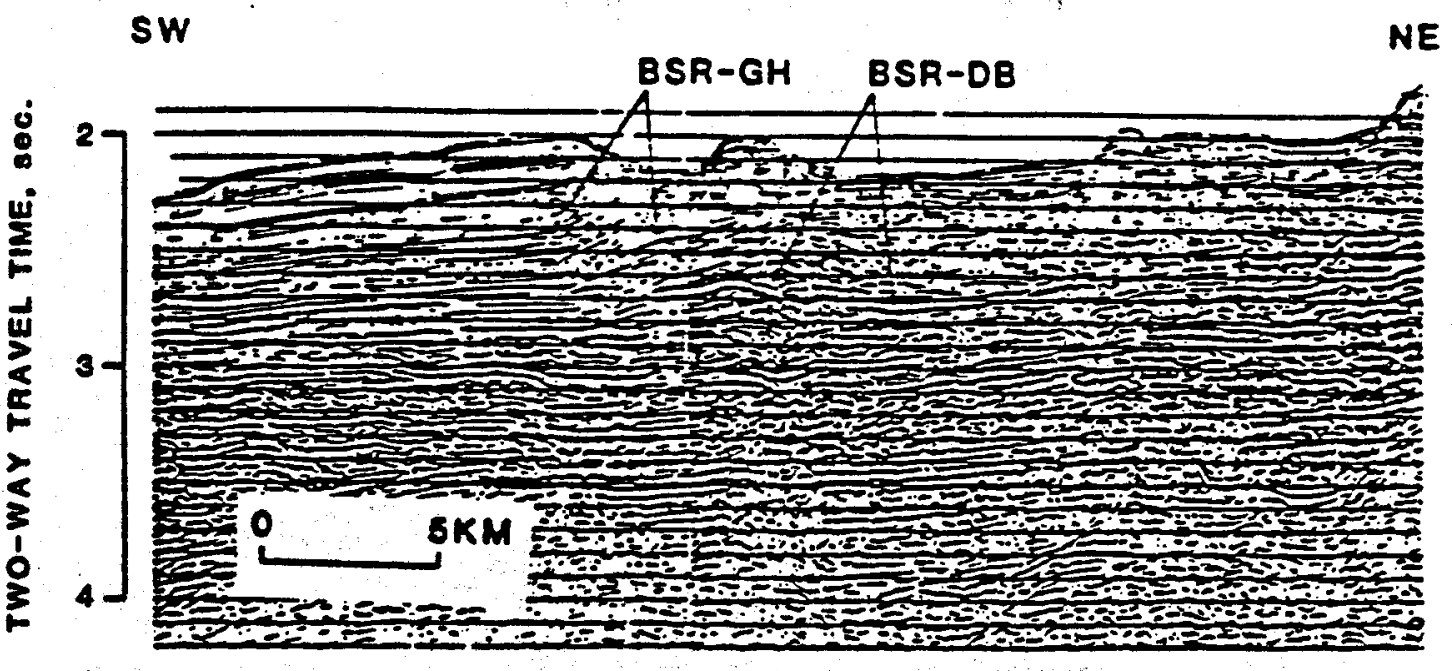

L 13

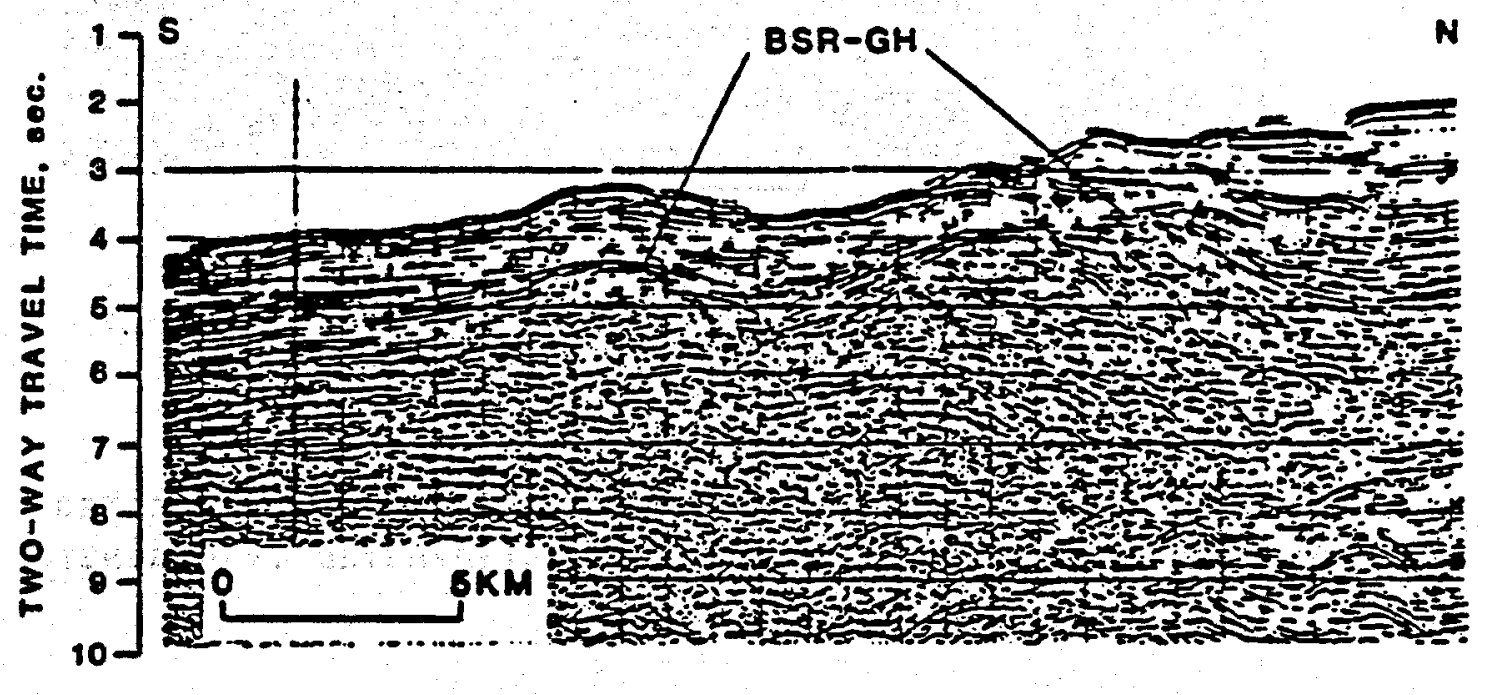

LOCATION OF PROFILES IS SHOWN IN FIGURE 62

88R-GH - BOTTOM SIMULATING REFLECTOR RELATED TO GAS HYDRATE

BSR-DB - BOTTOM SIMULATING REFLECTOR INTERPRETED AS A DIAGENETIC

Figure 64. SEISMIC LINES FROM THE NAVARIN BASIN REGION 


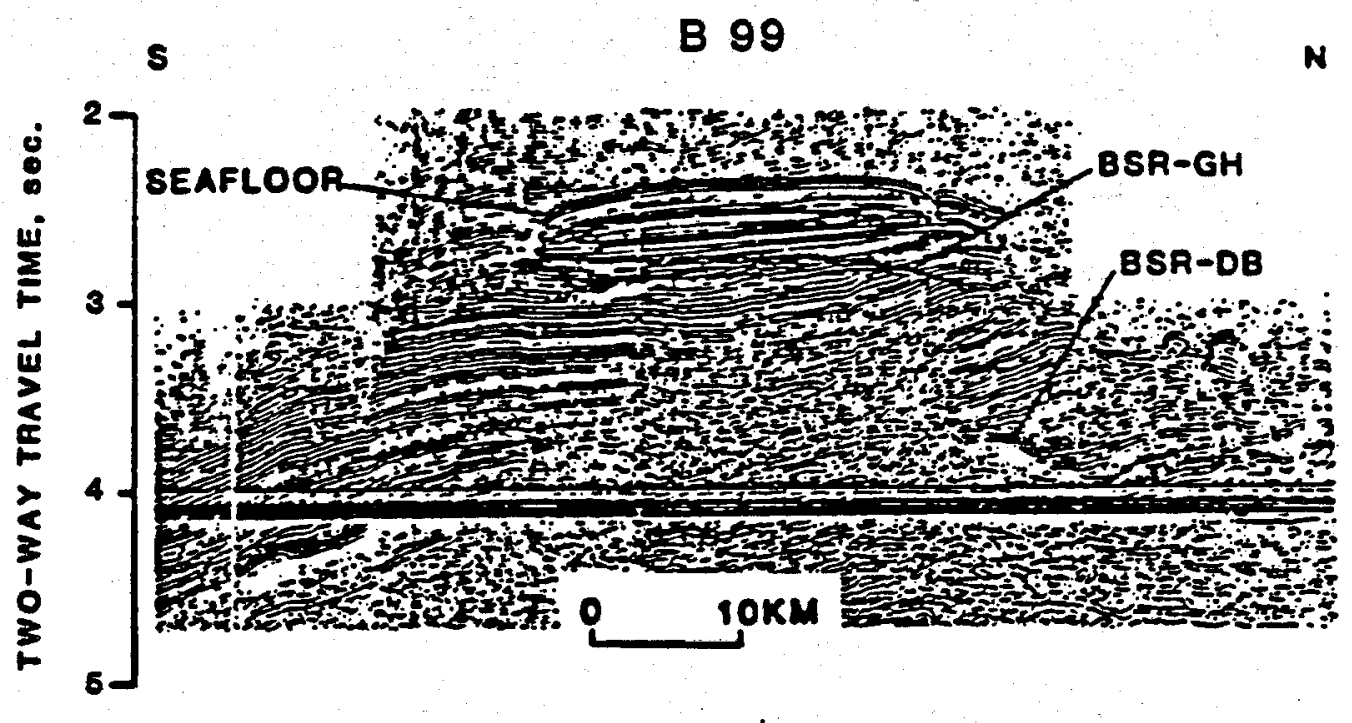

LOCATION OF PROFILE SHOWN IN FIGURE 62

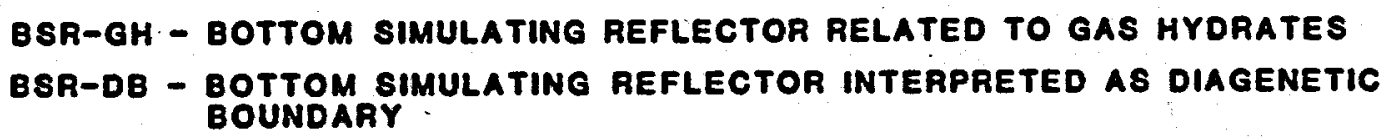

Figure 65. SEISMIC LINE FROM THE NAVARIN BASIN REGION After Marlow et al., 1981 
seismic data from the Norton Basin has not revealed the presence of the anomalous reflectors which may indicate gas hydrate occurrence. Such results appear to be consistent with the analyses of various geological factors directly controlling the formation of gas hydrates. The following factors appear to create adverse conditions for gas hydrate generation:

1. shallow sea depth,

2. Low thermogenic and biogenic hydrocarbon generation,

3. low pore water saturation in hydrocarbon gases,

4. relatively high temperatures at sea-floor,

5. high geothermal gradient,

6. apparent lack of mechanisms which could rapidly increase the amount of gas in the free phase in pore space.

The present sea depth within the Norton Basin ranges from 0 to $25 \mathrm{~m}$. Such a small water column creates unfavorable conditions for gas hydrate formation in at least some ways. Ubiquity of gas hydrates occurrence is usually related to widespread biogenic hydrocarbon generation which requires a reducing environment. In the formation of gas hydrate, stable low temperatures are also indispensable. Neither of these conditions can be fullfilled in the shallow sea environment. Additionally, the stabilizing role of hydrostatic pressure is strongly diminished in the Norton Basin region.

Low-level hydrocarbon generation is probably. an important factor responsible for the low gas hydrate potential in the region. Hydrocarbon gases of dual origin are being found in pore water in quantities well below saturation points.

The structural features of the basin do not show abrupt deformations in the upper stratigraphic sections. Presence of such deformation could indicate tectonic events leading to a change of pore water saturation balance in gas thus causing release of the gas in a free phase.

Norton Basin is characterized by a relatively high temperature gradient reaching $4.3^{\circ} \mathrm{C} / 100 \mathrm{~m}$. This factor, however, does not eliminate the gas hydrate potential in the Norton Basin region; it severely narrows the limits of the lower theoretical boundary of the hydrate zone to approximately $90 \mathrm{~m}$ subbottom depth.

Despite the above listed negative indications for gas hydrate in Norton Basin their potential occurrence cannot be discarded entirely. The whole area was evolving in a subaerial environment during the Pleistocene epoch when permafrost was ubiquitous and gas hydrates could form. The remnants of these zones could be presented in form of patchy and isolated zones. More geological and geochemical data are required, however, for delineation of these zones.

\section{Atka Basin}

The Atka Basin in the vicinity of DSDP sites 186 and 187 is the least documented of the four study areas, with regard to the bottom simulating reflectors (BSR) attributed to gas hydrates. Although some good quality seismic lines from the vicinity of DSDP Site 186 were reviewed we have not encountered gas hydrate related BSRs. At the same time we were unable to acquire those seismic lines from the same area on which the BSRs were positively identified (Scholl, personal commun.). Further confirmation of gas 
hydrate presence requires more indirect (multi-channel seismic reflection survey) as well as direct data (geochemical survey). The analysis of geological factors pertaining to gas hydrates in the Atka Basin suggest that despite a moderate prognosis with regard to hydrocarbon generation, high rates of sedimentation and low heat flow constitute favorable conditions for gas hydrate formation in the region.

\section{Eastern Aleutian Trench-Arc System}

The location of the BSRs (bottom simulating reflectors) commonly attributed to gas hydrate occurrence in the eastern Aleutian Trench area as listed by Kvenvolden and Barnard (1983) has been only defined as "North Pacific Ocean, south of Aleutian Islands". This gas hydrate occurrence was referenced on the basis of personal communication with Brun from the U.S. Geological Survey (Kvenvolden and Barnard, 1983). There are some indications that gas hydrates are present mainly in the area of the upper continental slope, north of the eastern Aleutian Trench. At the same time geochemical and other geological data seem to suggest that large amounts of methane are likely to be produced as a result of active subduction of sediment with subsequent thermal cracking of the organic matter (Kvenvolden and von Huene, 1985). The occurrence of biogenically derived methane has also been confirmed in DSDP sites of Legs 18 and 19 (Claypool, 1973). Both thermogenic and biogenic gases can be potentially supplied to the zones of gas hydrate formation.

As the location of previously identified BSR in the region was not precisely outlined, we have made strong efforts toward reviewing all publicly available seismic data from this region. Our search was based primarily on approximately $2,800 \mathrm{~km}$ of 24 channel seismic reflection profiles from western Gulf of Alaska collected by the USGS in 1977 and on the seismic sections between Kodiak Island and Aleutian Trench published by von Huene et al. (1979). Thorough review of these high quality geophysical data proved to be discouraging with regard to the identification of the BSRs related to gas hydrates. Only two relatively weak and discontinuous reflectors have been interpreted as the lower boundary of gas hydrate bearing zone on the seismic section published by von Huene et al. (1979) (Figure 66). One of these anomalous reflectors is located in the upper continental slope at the subbottom depth of $0.4 \mathrm{sec}$. The ocean depth in this area ranges from 2,000 to $2,400 \mathrm{~m}$. The second bottom simulating reflector has been identified in the middle section of the continental slope. Its subbottom depth is approximately $0.6 \mathrm{~s}$ where the oceanic water column reaches $3,000 \mathrm{~m}$. Such depression of the lower boundary of the hydrate zone with increased ocean depth was used by Shipley et al. (1979) as an important feature in the identification of gas hydrate related BSRs.

The discontinuous and random occurrence of BSRs in the eastern Aleutian Trench-Arc region seems to be consistent with the results of analyses of geological factors controlling gas hydrate formation. Among these factors relatively low levels of biogenic hydrocarbon generation appears to be the most critical. Large amounts of thermogenic methane generated as a result of active subduction, as suggested by Kvenvolden and von Huene (1985), may have contributed to the formation of discontinuous gas hydrate zones in the vicinity of faults acting as migration pathways for the gas. Correlation of both elements must await further advances in understanding of the structural geology and tectonics of the region. 
$\sqrt{-136-}$

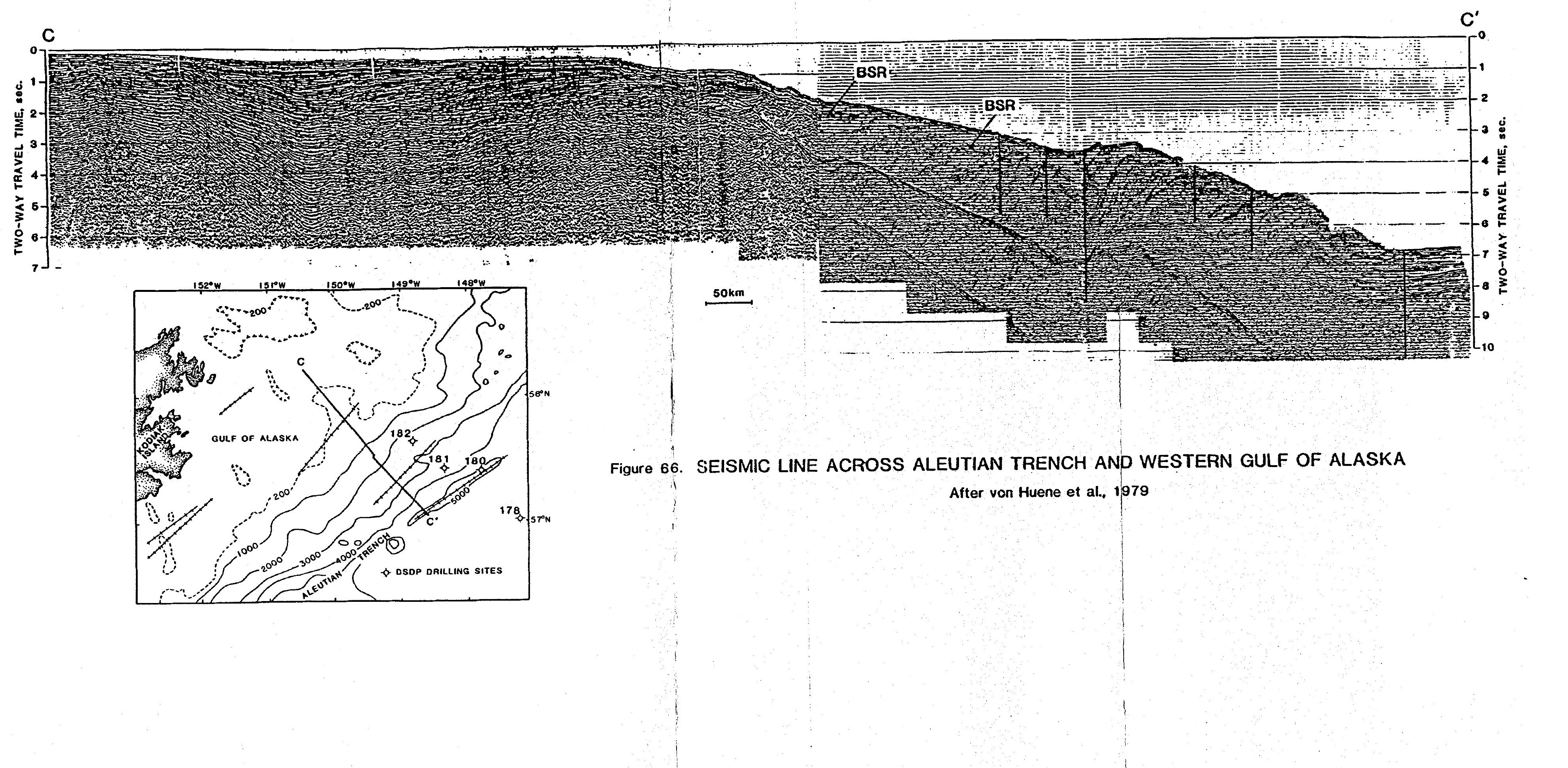




\section{Assessment of Gas Resources in Gas Hydrates}

The presence of gas hydrates has not been directly confirmed in any of the four study areas of the Bering Sea and Aleutian Trench-Arc regions. In all these areas, with the exception of the Norton Basin, the basic temperatures and pressures required for gas hydrate stability seem to be adequate.

The gas hydrates related to anomalous bottom simulating reflectors (BSRs) could be identified in western flanks of the Navarin Basin and eastern Aleutian Trench-Arc sedimentary complex. Both areas coincide with upper and middle continental slopes. The BSRs appear to be relatively weak, discontinuous and sporadic. Limited gas avallability is the most probable cause for such rare gas hydrate occurrence. The calculations of gas reserves within the two areas with identified BSRs produced the following results.

\section{Navarin Basin.}

The estimated area of gas hydrate zone extended between isobaths 1,000 and $2,000 \mathrm{~m}$ equals $1.5 \times 10^{10} \mathrm{~m}^{2}$. Assuming $40 \%$ sediment porosity and $12 \%$ pore space filling, $5 \%$ of the sediment will be filled with gas hydrate. Using the 200:1 gas volume conversion factor from gas hydrates suggested by Kuuskraa (1983) for standard conditions, and $10 \%$ areal extent of hydrates, the estimated gas reserves in hydrate state should be:

$1 \mathrm{~m}$ thickness $\times 1.5 \times 10^{10} \mathrm{~m}^{2}$ area $\times 5 \%$ hydrate $x 10 \%$ areal extent $\times 200$ volume conversion factor $=$

$$
1.5 \times 10^{10} \mathrm{~m}^{3}(0.53 \mathrm{TCF})
$$

$$
\begin{aligned}
& 1 \mathrm{~m}=1.5 \times 10^{10} \mathrm{~m}^{3}(0.53 \mathrm{TCF}) \\
& 100 \mathrm{~m}=1.5 \times 10^{12} \mathrm{~m}^{3} \text { (53 TCF) } \\
& 200 \mathrm{~m}=3.0 \times 10^{12} \mathrm{~m}^{3} \text { (106 TCF) } \\
& 300 \mathrm{~m}=4.5 \times 10^{12} \mathrm{~m}^{3} \text { (159 TCF) }
\end{aligned}
$$

Eastern Aleutian Trench-Arc Area. The Indirect evidence of gas hydrate presence was found at a sea depth of 2,025 to $2,250 \mathrm{~m}$. Assumed aerial extent of this zone is $3.49 \times 10^{10} \mathrm{~m}^{3}$. Further similar assumptions used in the gas reserves estimate for the Navarin Basin yield the following results:

$1 \mathrm{~m}$ thickness $\times 3.49 \times 10^{10}$ area $\times 5 \%$ hydrate

$\times 10 \%$ areal extent $\times 200$ volume conversion factor $=$

$$
3.49 \times 10^{10} \mathrm{~m}^{3} \text { (1.23 TCF) }
$$

$$
\begin{aligned}
1 \mathrm{~m} & =3.49 \times 10^{10} \mathrm{~m}^{3}(1.23 \mathrm{TCF}) \\
100 \mathrm{~m} & =3.49 \times 10^{12} \mathrm{~m}^{3}(123 \mathrm{TCF}) \\
200 \mathrm{~m} & =6.98 \times 10^{12} \mathrm{~m}^{3}(246 \mathrm{TCF}) \\
300 \mathrm{~m} & \left.=17.45 \times 10^{12} \mathrm{~m}^{3} \text { (369 TCF }\right)
\end{aligned}
$$




\section{Conclusions}

The four study areas examined in this report constitute only portions of two vast regions of the Bering Sea and Aleutian Trench-Arc system. Various tectonic positions of the areas produced, however, a significant diversity of major parameters controlling gas hydrate formation. The latter fact necessitated the separate treatment of the four designated areas all along the study.

The factor which had a meaningful impact on this study is data availability. Particularly in the area of the Aleutian Trench-Arc system, the regional nature and scarcity of direct data from boreholes made it possible to reveal only general controls of hydrocarbon generation and potential accumulation in the form of gas hydrates. Although the number of drilled wells in the Navarin and Norton basins is more favorable with regard to existing data than in the remaining two areas, the overwhelming amount of direct information from these wells is kept as proprietary data.

The assumption of gas hydrate presence in Navarin and Norton basins, Atka Basin and the eastern Aleutian Trench-Arc complex is based on seismic evidence, namely on bottom simulating reflectors (BSRs). Although these seismic reflectors have been claimed to be present in all four study areas (Kvenvolden and Barnard, 1983), we were able to identify them only in two areas, namely in the upper and middle continental slopes in the west flanks of Navarin Basin and the eastern Aleutian Trench-Arc sedimentary complex. The BSRs in these two areas are represented by relatively weak and discontinuous reflectors. Under the favorable thermal conditions, relative scarcity can usually be explained by insufficient gas supply. On the other hand, gas hydrates are often detected in the areas where favorable thermal conditions coincide with widespread biogenic hydrocarbon generation.

In the four studied areas only limited biomethanogenesis takes place. At the same time, the migration of thermogenically derived gases from deeper stratigraphic sections is at least considerably diminished due to apparently ubiquitous silica (opal C-T) horizons.

The presence of gas hydrates in Norton Basin cited by Kvenvolden and Barnard (1983) on a basis of personal communication with Rousseau seems to be somehow questionable. Apart from the fact that identifications of the anomalous reflectors rêtated to gas hydrates are difficult because of the structural features, shallow water column, relatively high water temperature, high geothermal gradient, low gas contents in sediments do not constitute favorable conditions for gas hydrate formation. Patchy and irregular gas hydrate zones eventually could be related to the remnants of permafrost preserved from the Pleistocene epoch and locally increased amounts of available thermogenic and biogenic hydrocarbons.

The examination of the main geological factors, crucial in the processes of gas hydrate formation and stability, made it possible to draw the following conclusions for individual study areas: 
Navarin Basin

1. Navarin Basin consists of three subbasins trending in a northwestern direction, where thickness of the sedimentary sequences reaches 3,658 $m$ to 4,573 m $(12,000$ to $15,000 \mathrm{ft})$.

2. The sediments of the upper strata in the basin are continuous and horizontal.

3. The structural traps for migrating hydrocarbons occur most likely in deeper sedimentary sections in the central part of the basin as well as in pinching-out strata of the basin's western flanks.

4. Faults which may act as the migrating paths strike predominantly in a northwest-southeastern direction and mostly occur on the continental slope and in outermost shelf areas.

5. In a vertical cross-section of Navarin Basin, the prevailing lithologies are marine sediments of middle bathyal to inner neritic zones.

6. The hydrocarbon gases in the sediments of Navarin Basin appear to be mostly of biogenic origin. Thermogenically derived hydrocarbons have also been found.

7. Rate of sedimentation in Navarin Basin ranging from 100 to 350 $\mathrm{m} / \mathrm{m} . \mathrm{y}$. constitutes the favorable factor in the process of biogenic methanogenesis.

8. In the profile of the N.B. COST 1 well, the values of organic carbon range from below 0.5 percent to 2 percent and probably represent average values for the entire Navarin Basin.

9. The best source of thermogenic hydrocarbons in the NB COST No. 1 well seems to occur at depths below $3,567 \mathrm{~m}(11,700 \mathrm{ft})$.

10. Significant differences in geothermal gradients in vertical profile of Navarin Basin (from $2.95^{\circ} \mathrm{C}$ to $4.46^{\circ} \mathrm{C} / 100 \mathrm{~m}$ ) are caused by the presence of the silica diagenetic boundaries.

11. The upper and middle continental slope appears to have the most favorable conditions for gas hydrate formation. Among these conditions the most important are:

a. increased blogenic methanogenesis,

b. increased amount of thermogenic hydrocarbons,

c. higher rate of sedimentation,

d. favorable thermal and pressure conditions,

12. The known BSRs related to gas hydrates occur in the continental slope area where water depths range from $1,000 \mathrm{~m}$ to $2,400 \mathrm{~m}$. The subbottom depths of BSRs vary from 200 to $500 \mathrm{~m}(0.3$ to $0.6 \mathrm{sec})$. 
13. Discontinuous and weak nature of the BSRs is most likely caused by lack of prolific biogenic methanogenesis in the area.

14. Assuming 10 percent areal extent of the gas hydrates and a $350 \mathrm{~m}$ thick hydrate zone limited by Isobaths $1,000 \mathrm{~m}$ and $2,800 \mathrm{~m}$, the gas reserves in the gas hydrate zone have been estimated at $185 \mathrm{TCF}$.

\section{Norton Basin}

1. Norton Basin constitutes a broad downwarped area within the northwestern Bering Sea shelf. The basin is composed of two subbasins, the St. Lawrence and Stuart, divided by the Yukon horst.

2. Norton Basin is filled with Tertiary sediments which outcrop on the basin's flanks.

3. The deepest parts of Norton Basin's basement lie at the subbottom depth of $3,800 \mathrm{~m}$.

4. Mudstones and siltstones interbedded with sandstones, shales and coal constitute major elements in the lithological profile of Norton Basin.

5. The upper 200 to $300 \mathrm{~m}$ of sediments lie horizontally without any major tectonic deformations.

6. The values of total organic carbon (TOC) in Norton Basin range from 0.8 percent to 2.0 percent. Extremely high values of TOC (reaching 50 percent) found in the Norton Basin COST 1 well coincide with the horizons containing coal.

7. Elemental analyses of kerogen in rock samples collected in the NB COST No. 1 well and plotted on the van Krevelen diagram (Figure 28) indicate the presence of Type III kerogen with poor hydrocarbon generation potential.

8. Vitrinite reflectance $\left(R_{0}\right)$, thermal alteration indices frequently used as main indicators of kerogen's themal maturity, show moderately matured kerogen in the deepest sections of the basin to an immature one in its shallower parts.

9. Only limited parts of the basin have favorable conditions for generation of thermogenic hydrocarbon gases.

10. The available geochemical data on the gaseous phase in the sediments and in sea-water column seem to suggest that most of the hydrocarbons in near-bottom sediments are thermogenically derived.

11. The biogenic processes of gas generation are more active only locally and have a modifying role on geochemical characteristics of the hydrocarbons in sediment. 
12. High geothermal gradient reaching 4 to $4.5^{\circ} \mathrm{C} / 100 \mathrm{~m}$ is characteristic for Norton Basin.

13. Shallow sea-water column ranging from 0 to $25 \mathrm{~m}$ over the entire basin seems to be unfavorable for gas hydrate formation mainly because of the oxidized environment and elevated temperatures at sea bottom.

\section{Atka Basin}

1. The structural geology of the accretionary complex associated with the Aleutian Trench is still poorly known.

2. In the vicinity of DSDP Sites 186 and 187, where the seismic evidence on gas hydrate presence was found, the sedimentary pile consists mainly of $925 \mathrm{~m}$ of silty clays and to a lesser extent volcanic ashes and silty sands.

3. Organic carbon in sediments of the accretionary complex in the vicinity of Atka Basin is found in values below 0.5 percent.

4. The high rate of sedimentation in Atka Basin, reaching $180 \mathrm{~m} / \mathrm{m} . \mathrm{y}$. , is a favorable element in prevention of organic matter oxidation.

5. Geochemical analyses of gaseous phase in sediments show its mostly biogenic origin.

6. Geothermal gradients in Atka Basin display low values of 1.8 to $2.5^{\circ} \mathrm{C} / 100 \mathrm{~m}$, typical for convergent margins.

7. Despite the favorable thermal and pressure conditions for gas hydrate formation in Atka Basin, the seismic evidence of their presence does not appear to be omnipresent. Insufficient gas supply to the potential gas hydrate zone is probably the key factor.

\section{Eastern Aleutian Trench-Arc}

1. The structural features of eastern Aleutian Trench-Arc system are still inadequately known.

2. Within the continental slope of this area, the prevailing lithologies consist of clayey silt and sands interbedded with volcanic ash.

3. Total organic carbon values in the sediments range from traces to $\mathbf{0 . 8}$ percent, averaging 0.6 percent.

4. The total hydrocarbon yield from the sediment samples of the eastern Aleutian Trench-Arc complex show low values ranging from 0.03 to 0.10 percent. 
5. The amounts of volatile hydrocarbons in sediments are low and do not exceed 200 ppm.

6. The potential of the sediments entering the subduction zone in the eastern Aleutian Trench area for thermogenic hydrocarbon generation was found to be moderate to low.

7. The average geothermal gradient within the eastern Aleutian TrenchArc complex is $2.8^{\circ} \mathrm{C} / 100 \mathrm{~m}$.

8. As there is no direct evidence on gas hydrate presence in the area, review of $2,500 \mathrm{~km}$ high resolution seismic lines did not reveal conspicuous bottom simulating reflectors (BSRs). Only weak and discontinuous BSRs were identified in the middle continental slope east of Kodiak Island.

9. Assuming the limitations of the gas hydrate occurrence in the eastern Aleutian Trench-Arc sedimentary complex, the gas reserve in the potential hydrate state has been assessed on 369 TCF. 


\section{REFERENCES}

Barker, C., 1974, Pyrolysis techniques for source rock evaluation: Am. Assoc. Petroleum Geologists Bull., v. 58, p. 2394 - 2361.

Bernard, B.B., Brooks, J.M., and. Sackett, W.M., 1976, Natural gas seepage in the Gulf of Mexico: Earth and Planet. Sci. Lett., v. 31, p. 48 - 54.

Bernard, B.B., Brooks, J.M., and Sackett, W.M., 1978, Light hydrocarbons in recent Texas continental shelf and slope sediments: Jour. Geophys. Res., v. 83 , p. $4053-4061$.

Bingham, D.K., and Stone, D.B., 1971, Paleosecular variation of the geomagnetic field in the Aleutian Islands, Alaska: unpub. rept., Geophysical Institute Univ. Alaska, College, Alaska, 30 p.

Bode, G.W., 1973, Carbon-carbonate, in Initial reports of the Deep Sea Drilling Project, v. 19: Washington, D.C., U.S. Govt. Printing Office, p. 663 666.

Bolm, J.G., 1983, Lithology and geophysical log interpretation, in R.F. Turner, ed., Geological and operational summary Norton Sound COST No. 1 well, Norton Sound, Alaska: U.S. Geological Survey, Open File Report 83-124, p. $58-97$.

Bryan, G.M., 1974, In situ indications of gas hydrates, in Kaplan, I.R., ed., Natural Gases in Marine Sediments: New York, Plenum Press, p. 299.

Carlson, P.R., Golan-Bac, M., Karl, H.A., and Kvenvolden, K., 1985, Seismic and geochemical evidence for shallow gas sediment on Navarin continental margin, Bering Sea: Am. Assoc. Petroleum Geologists Bull., v. 63, No. 3, p. 422 - 435 .

Claypool, G.E., and Kaplan, I.R., 1974, The origin and distribution of methane in marine sediments, in I.R. Kaplan, ed., Natural gases in marine sediments: New York Plenum Press, p. $99-139$.

Claypool, G.E., Presley, B.J., and Kaplan, I.R., 1973, Gas analyses in sediment samples from Legs $10,11,13,14,15,18$ and 19 , in Initial reports of the Deep Sea Drilling Project, Kodiak, Alaska to Yokohama, Japan: Washington, D.C., U.S. Govt. Printing Office, v. 19, p. 879 - 884. 
Claypool, G.E., and Reed, P.R., 1976, Thermal analysis technique for sourcerock evaluation: quantitative estimate of organic richness and effects of lithologic variation: Am. Assoc. Petroleum Geologists Bull., v. 60, p. $608-626$.

Cline, J.D., and Holmes, M.L., 1977, Submarine seepage of natural gas in Norton Sound, Alaska: Science no. 198, p. 1149 - 1153.

Cooper, A.K., Scholl, D.W.,Marlow, M.S., Childs, J.R., Redden, G.D., Kvenvolden, K.A., and Stevenson, A.J., 1979, Hydrocarbon potential of Aleutian Basin, Bering Sea: Am. Assoc. Petroleum Geologists Bull., v. 63, p. 2070 - 2087.

Creager, J.S., Scholl, D.W., Boyce, R.E., Echols, R.Y., Lee, H.J., Ling, H.Y, Steward, R.J., Supko, P.R., and Worsley, T.R., 1973, Site reports, in Initial reports of the Deep Sea Drilling Project, Honolulu, Hawaii to Kodiak, Alaska: Washington, D.C., U.S. Govt. Printing Office, v. 86, p. 217.

Dickinson, W.R., and Seely, D.R., 1979, Structure and stratigraphy of forearc regions: Am. Assoc, Petroleum Geologists Bull, v. 63, p. 2 - 31.

Dillon, W.P., and Paull, C.K., 1980, Unconventional gas hydrate seals may trap gas off southeast U.S. : Oil and Gas Jour., v. 78, no. 1, p. 124.

Dott, R.H., 1964, Wacke, graywacke and matrix--what approach to immature sandstone classification?: Jour. Sed. Petrology, v. 34, p. 625.

Dow, W.G., 1977, Kerogen studies and geological interpretations: Journal of Geochemical Exploration, v. 7, no. 1, p. 79 - 99.

Dow, W.G., and O'Connor, D.J., 1982, Kerogen maturity and type by reflected light microscopy applied to petroleum exploration: in How to assess maturation and paleotemperatures, SEPM Short Course no. 7, Tulsa, Society of Economic Paleontologists and Mineralogists, p. 133 - 157. Durand, B., and Espitalie, J., 1972, Formation and evolution of $C_{1}$ and $C_{15}$
hydrocarbons and permanent gases in the Toarcian clays of the Paris Basin, in H.R. Gaertner and H. Wehner, eds., Advances in organic geochemistry: Pergamon Press, Oxford, p. 455 - 468.

Erickson, B.H., and Grim, P.J., 1969, Profiles of magnetic anomalies south of the Aleutian Island arc: Geol. Society America Bull., v. 80, p. 1387. 1390.

Espitalie, J., Laporte, J.L., Madec, M., Marquis, F., Leplat, P., Paulet, J., and Boutefeu, A., 1977, Methode rapide de caracterisation des roches meres, de leur potentiel petrolier et de leur degre d'evolution: Revue de l'Institute Francais du Petrole, v. 32, p. 23 - 42.

Ewing, J.I., and Hollister, P., 1972, Regional aspects of deep sea drilling in the western North Atlantic, in Initial reports of the Deep Sea Drilling Project, Miami, Florida to Hoboken, New Jersey, v. 11, Washington, D.C., U.S. Govt. Printing Office, p. 951 - 973. 
Filatova, N.I., 1979, Cretaceous-Paleogene volcanism of the transition zone between the Verkoyansk-Chukchi and Koryak-Kamchatka regions: Geotectonics, v. 13, p. $402-412$.

Fisher, M.A., 1982, Petroleum geoloyof Norton Basin, Alaska: Am. Assoc. Petroleum Geologists Bull., v. 66, p. 286 - 301.

Fisher, J.M., Carlson, P.R., and Kart, H.A., 1982, Bathymetric map of Navarin Basin province: U.S. Geological Survey Open File Report, 82 - 1038.

Fitch, T.J., 1972, Plate convergence, transcurrent faults, and internal deformation adjacent to southeast Asia and the western Pacific: Jour. Geophys. Research, v. 77, p. 4432 - 4460 .

Flett, T.O., 1984, Organic geochemistry, in R.F. Turner, Geological and operational summary, Navarin Basin COST No. 1 well, Bering Sea, Alaska, p. 199 - 221 .

Flörke, O.W.: 1955, Zur Frage des 'Hoch'--Gristobalit in Opalen, Bentomiten und Gläsern: Neues Jb. Mineral. Mh., v. 10, p. $217-223$.

Francheteau, J.H., Harrison, C.G.A., Sclater, Y.G., and Richards, M.L., 1970, Magnetization of Pacific seamounts: A preliminary polar curve for the northeastern Pacific: Jour. Geophys. Research, v. 75, p. 2035 - 2064.

Fuex, N., 1977, The use of stable isotopes in hydrocarbon exploration: Jour. Geochem. Exploration, v. 7, p. 155 - 188.

Gates, O., and Gibson, W., 1956, Interpretation of the configuration of the Aleutian Ridge: Bull. Geol. Soc. Am., v. 67, p. 127 - 146.

Gealy, E.L., and Dubois, R., 1971, Shipboard geochemical analysis, Leg 7, in Initial reports of the Deep Sea Drilling Project, v. 7: Washington, D.C., U.S. Govt. Printing Office, p. 863.

Gershanovich, D.E., 1968, New data on geomorphology and recent sediments of the Bering Sea and the Gulf of Alaska: Marine Geology, v. 6, p. 281 296.

Grayson, J., and La Plante, R.E., 1973, Estimated temperature history in the lower part of hole 181 from carbonization measurements, in L.D. Kulm et al., Initial reports of the Deep Sea Drilling Project, Honolulu, Hawail to Kodiak, Alaska: Washington, D.C., U.S. Govt., Printing Office, v. 18, p. 1077.

Griffin, J.J., Koide, M., Höhndorf, A., Hawkins, J.W., and Goldberg, E.D., 1972, Sediments of the Lau Basin rapidly accumulating volcanic deposits: Deep Sea Res., v. 19 , p. $139-148$.

Grow, J.A., 1973, Crustal and upper mantle structure of the central Aleutian arc: Geol. Soc. America Bull., v. 84, p. 2169 - 2192. 
Grow, J.A., and Atwater, T., 1970, Mid-Tertiary tectonic transition in the Aleutian arc: Geol. Soc. America Bull., v. 81, p. 3715 - 3722.

Halleck, P.M., 1982, In situ physical properties of natural gas hydrate deposits, in R. Malone, ed., Methane Hydrates Workshop Technical Proceedings, p. $\overline{63}-72$.

Hampton, M.A., and Kvenvolden, K.A., 1981, Geology and geochemistry of gas-charged sediment on Kodiak shelf, Alaska: Geo-Marine Letters, v. 1, p. $141-147$.

Hayes, D.E., and Ewing, M., 1970, Pacific boundary structure, in A.E. Maxwell, ed., The sea, vo 4, part II: New York, p. 29 - 38.

Hein, J.R., Scholl, D.W., Barron, J.A., Jones, M.G., and Miller, J., 1978, Diagenesis of late Cenozoic diatomaceous deposits and formation of the bottom simulating reflector in the southern Bering Sea: Sedimentology, v. 25 , p. $155-181$.

Holmes, M.L., and Thor, D.R., 1982, Distribution of gas-charged sediment in Norton Sound and Chirikov Basin, northeastern Bering Sea: Geologie en Mijnbouw, p. $79^{\circ}-89$.

Hudson, T., 1977, Preliminary geologic map of Seward Peninsula, Alaska: U.S. Geological Survey Open File Report. OF-77-796A.

Hunt, J.M., 1974, Hydrocarbon geochemistry of Black Sea, in The Black Sea-Geology, Chemistry and Biology: Am. Assoc. Pet. Geol. Mem. 20, p. 499 - 504.

Hunt, J.M., 1979, Petroleum geochemistry and geology: San Francisco, W.H. Freeman, $617 \mathrm{p}$.

Jones, J.B., and Segnit, E.R., 1971, The nature of opal 1. Nomenclature and constituent phases: Journ. Geol. Soc. Aust., v. 18, no. 1, p. 57 - 68.

Kosiur, D.R., and Warford, A.L., 1979, Methane production and oxidation in Santa Barbara Basin sediment: Estuarine Coastal Mar. Sci., v. 8, p. 379 385.

Kvenvolden, K.A., and Barnard, L.A., 1983, Hydrates of natural gas in continental margins, in Watkins, J.S., and Drake, C.L., eds., Studies in continental margin geology: Am. Assoc. Petroleum Geologists Mem. 34, p. 631 .

Kvenvolden, K.A., and Field, M.E., 1981, Thermogenic hydrocarbons in unconsolidated sediment of Eel River Basin, offshore northern California: Am. Assoc. Petroleum Geologists, v. 65, p. 1642 - 1646.

Kvenvolden, K.A., and McMenamin, M.A., 1980, Hydrates of natural gas: a review of their geological occurrences: U.S. Geol. Survey Circ. 825, 11 p. 
Kvenvolden, K.A., Nelson, C.H., Thor, D.R., Lărsen, M.C., Redden, G.D., Rapp, J.B., and Des Marais, D.J., 1979, Biogenic and thermogenic gas in gas-charged sediment of Norton Sound, Alaska: OTC 3412 , 11th Annual Offshore Technology Conference, Houston, Texas, p. 479 - 483.

Kvenvolden, K.A., and Redden, G.D., 1980, Hydrocarbon gas in sediment from the shelf, slope and basin of the Bering Sea: Geochimica and Cosmochimica Acta, vo 44 , p. $1145-1150$.

Kvenvolden, K.A.; Vogel, T.M., and Gardner, J.V., 1981, Geochemical prospecting for hydrocarbons in outer continental shelf, southern Bering Sea, Alaska: Journal of Geochemical Exploration, v. 14, p. 209 - 219.

Kvenvolden, K.A., and von Huene, 1985, Natural gas generatin in sediments of the convergent margin of the eastern Aleutian Trench area, in D.G. Howell, ed., Tectonostratigraphic terranes of the circum-Pacific region, p. $31-49$.

Kvenvolden, K.A., Weliky, K., Nelson, H., and Des Marais, D.J., 1979, Submarine seep of carbon dioxide in Norton Sound, Alaska: Science, v. 205,p. $1254-1266$.

Lachenbruch, A.H., and Sass, J.H., 1980, Heat flow and eneretics of the San Andreas fault zone: Jour. Geophys. Research, v. 85, no. B11, p. 6185 6222.

Lancelot, Y., and Ewing, J.I., 1972, Correlation of natural gas zonation and ..carbonate diagenesis in Tertiary sediments from the northwest Atlantic, in Initial reports of the Deep Sea Drilling Project, Miami, Florida to Hoboken, New Jersey: Washington, D.C., U.S. Govt. Printing Office, v. 11, p. 791 .

Lisitsin, A.P., 1966, Processes of recent sedimentationin theBering Sea: Nauka, Moscow, 574 p.

Lopatin, N.V., 1969, The main stage of petroleum formation (in Russian): Izv. Akad. Nauk SSSR, Ser. Geol., p. 69 - 76.

Magoon, L.B., and Claypool, G.E., 1981, Petroleum geology of Cook Inlet Basin, Alaska--An exploration model: Am. Assoc. Petroleum Geologists Bull,, v. 65, p. 355 - 374.

Malakoff, A., and Erickson, B.H., 1969, Gravity anomalies over the Aleutian Trench: Am. Geophys. Union Transactions, v. 50, p. 552 - 555.

Mammerickx, J., 1970, Morphology of the Aleutian abyssal plain: Geol. Soc. America Bull., v, 81, p. 3457 - 3464.

Marlow, M.S., 1979, Hydrocarbon prospects in Navarin Basin province, northwest Bering Sea shelf: Oil and Gas Jour,, October 29, p. 190 - 196. 
Marlow, M.S., Carlson, P.R., Cooper, A.K., Carl, H.A., McLean, H., McMullin, R., and Lynch, M.B., 1981, Resource report for proposed OCS sale 83, Navarin Basin, Alaska: U.S. Geol. Survey Open File Report 81-252, 83 p.

Marlow, M.S., and Cooper, A.K., 1980, Mesozoic and Cenozoic structural trends under southern Bering Sea shelf: Am. Assoc. Petroleum Geologists Bull., v. 64, p. $2139-2155$.

Marlow, M.S., Scholl, D.W., Cooper, A.K., and Buffington, E.C., 1976, Structure and evolution of Bering Sea shelf south of St. Lawrence Island: Am. Assoc. Petroleum Geologists Bull., v. 60, p. 161 - 183.

Marlow, M.S., Scholl, D.W., Vallier, T.L., and McLean, H., 1979, Description of dredge samples from the Bering Sea continental margin: U.S. Geol. Survey Open File Report 79-1139, 6 p.

Martin, G.C., 1984, Geothermal gradient, in R.F. Turner, ed., Geological and operational summary, Navarin Basin COST No. 1 well, Bering Sea, Alaska, p. 193 - 198.

Martens, C.S., and Berner, R.A., 1974, Methane production in the interstitial waters of sulfate-depleted marine sediments: Science, v. 185, p. 1167 1169.

Mathews, M.A., 1983, Logging characteristics and methane gas estimate of methane hydrate deposits [paper presented at September 28, 1983 meeting of SPWLA Four Corners Well Logging Society Chapterl.

Mattson, P.H., and Pessagno, E.A., 1971, Caribbean Eocene volcanism and the extent of Horizon A: Science, V. 174, p. 138 - 139.

McCarthy, J., and Scholl, D.W., 1985, Mechanisms of subduction accretion along the central Aleutian Trench: Geol. Soc. America Bull., v. 96, p. 691 - 701 .

McIver, R.D., 1973, Hydrocarbons in canned muds from Sites 185, 186, 189 and 191, Leg 19, in J.S. Creager and D.W. Scholl, eds., Initial reports of the Deep Sea Drilling Project, v. 19: Washington, D.C., U.S. Govt. Printing Office, p. $875-877$.

McLeod, M.K., 1982, Gas hydrates in ocean bottom sediments: Am. Assoc. Petroleum Geologists Bull., v. 6, p. 2649 - 2662.

Menard, H.W., 1967, Transitional types of crust under small ocean basins: Jour. Geophys. Research, v. 72, p. 3061 - 3073.

Miller, T.P., 1972, Potassium-rich alkaline intrusive rocks of western Alaska: Geol. Soc. America Bull., v. 83, p. 2111 - 2128.

Nelson, C.H., Kvenvolden, K.A., and Clukey, E.C., 1978, Thermogenic gases in near-surface sediments of Norton Sound: OTC 3354, 10th Annual Offshore Technology Conference, Houston, Texas, p. $2623-2633$. 
Nelson, C.H., Thor, D.R., Sandstrom, M.W., and Kvenvolden, K.A., 1979, Modern biogenic gas-generated craters (sea-floor 'pock-marks') on the Bering shelf, Alaska: Bull., Geol. Soc. America, part I-90, p. 1144 1151 .

Oehler, J.H., 1973, Trymidite-like crystals in cristobalite 'cherts': Nature, v. 241, p. $64-65$.

Parfenov, L.M., et al., 1979, Geodynamics of northeastern Asia in Mesozoic and Cenozoic time and the nature of volcanic belts, in S. Uyeda, R.W., Murphy and K.Kobayashi, eds., Geodynamics of western Pacific: Advances in Earth and Planetary Sciences 6, Tokyo, Japan, Sci. Soc. Press, p. 503 $-525$.

Patton, W.W., Jr., 1973, Renaissance geology of the northern Yukon-Koyukuk province, Alaska: U.S. Geol. Survey Prof. Paper 774-A, p. A1-A17.

Patton, W.W., and Csejtey, B., Jr., 1971, Preliminary geologic investigations of western St. Lawrence Island, Alaska: U.S. Survey Prof. Paper 684-C, p. C1-C5.

Patton, W.W., and Csejtey, B., Jr., 1980, Geologic map of St. Lawrence Island, Alaska: U.S. Geological Survey Misc. Inv. Map 1-1203, 1 sheet, scale $1: 250,000$.

Patton, W.W., Lanphere, M.A., Miller T.P., and Scott, R.A., 1974, Age and tectonic significance of volcanic rocks on St. Matthew Island, Bering Sea, Alaska (abc.): GSA Abstracts with Programs, v. 6, p. 905 - 906.

Patton, W.W., Lanphere, M.A., Miller T.P., and Scott, R.A., 1976, Age and tectonic significance of volcanic rocks on St. Matthew Island, Bering Sea, Alaska: U.S. Geol. Survey Jour. of Res., v. 4, p. 67 - 73.

Patton, W.W., and Teilleur, I.L., 1977, Evidence in the Bering Strait region for differential movement between North America and Eurasia: Geol. Soc. America Bull., v. 80 , p. 1298 - 1304.

Paull, C.K., and Dillon, W.P., 1981, Appearance and distribution of the gas hydrate reflection in the Blake Ridge region, of fshore southeastern U.S.: U.S. Geol. Surv. Misc. Field Studies Map MF-1252.

Pitman, W.C., III, and Hayes, D.E, 1968, Sea-floor spreading in the Gulf of Alaska: Jour, Geophys. Research, v. 73, p. $6571-6580$.

Pratt, R.M., Scheidegger, K.F., and Kulm, L.D., 1973, Volcanic ash from DSDP Site 178, Gulf of Alaska, in Initial reports of the Deep Sea Drilling Project, Honolulu, Hawail to Kodiak, Alaska: Washington, D.C., U.S. Govt. Printing Office, v. 18, p. $833-834$.

Primrose, S.B., and Dilworth,M.J., 1976, Ethylene production by bacteria Jour. of General Microbiology, v. 93, p. $177-181$.

Ronov, A.B., 1958, Organic carbon in sedimentary rock (in relation to presence of petroleum): Geochemistry, no. 5, p. $510-536$. 
Royden, L., Gelater, J.G., and von Herzen, R.P., 1980, Continental margins subsidence and heat flow: important parameters in formations of petroleum hydrocarbons: Am. Assoc. Petroelum Geologists Bull., v. 4, p. 173 - 187.

Russ, T., 1983, Geochemical final well report, ARCO Alaska Inc., Navarin Basin COST No. 1, Anchorage: Exploration logging (WSA), Inc., 80 p.

Sandstrom, M.W., Meredith, D., and Kaplan, I.R., 1983, Hydrocarbon geochemistry in surface sediments of Alaskan outer continental shelf, part 2. Distribution of hydrocarbon gases: Am. Assoc. Petroleum Geologists Bull., v. 67, p. $2047-2052$.

Scholl, D.W., and Buffington, E.C., 1970, Structural evolution of Bering continental margin; Cretaceous to Holocene (abs.): Am. Assoc. Petroleum Geologists Bull, v. 54, p. 2503.

Scholl, D.W., Buffington, E.C., and Marlow, M.S., 1975, Plate tectonics and the structural evolution of the Aleutian-Bering Sea region, in R.B. Forbes, Contributions to the geology of the Bering Sea basin and adjacent regions: GSA Special Paper 151, p. 1 - 32.

Scholl, D.W., and Creager, J.S., 1973, Geologic synthesis of Leg 19 (DSDP) results; far north Pacific and Aleutian Ridge, and Bering Sea, in Initial reports of the Deep Sea Drilling Project, Kodiak, Alaska to Yokohama, Japan: Washington, D.C., U.S. Govt. Printing Office, v. 76, p. $897-913$.

Scholl, D.W. Vallier, T.L., Stevenson, A.J., 1983,Arc, Forearc and trench sedimentation and tectonics; Amlia Corridor of Aleutian Ridge, in Watkins, J.S. and Drake, C.L., eds., Studies in continental margin geology: Am. Assoc. Petroleum Geologists Mem. 34, p. 413 - 438.

Schubel, J.R., 1974, Gas bubbles and acoustically impenetrable, or turbid character of some marine sediments, in I.R. Kaplan, ed., Natural gases in marine sediments: New york, Plenum Press, p. 275 - 298.

Sclater, J.G., and Christie, P.A., 1980, Continental stretching; an explanation of the post-mid-Cretaceous subsidence of the central North Seabasin: Jour. Geophys. Research, v. 85, p. 3711 - 3739.

Sclater, J.G., and Jarrard, R.D., 1971, Preliminary paleomagnetic results, Leg 7, in Winterer, E.L., and others, eds., Initial reports of Deep Sea Drilling Project, v. VII: Washington, D.C., U.S. Govt. Printing Office, p. 1227 1234.

Seely, D.R., 1978, The evolution of structural highs bordering major forearc basins, in J.S. Watkins, L. Montadert, and P. W. Dickerson, eds., Geologica and Geophysical investigations of continental margins: Am. Assoc. Petroleum Geologists Mem. 29, p. 245 - 260.

Shepard, F.P., 1963, Submarine geology: 2nd ed. Harper and Row, New York, N.Y., 554 p. 
Shipley, T.H., Houston, M.H., Buffler, R.T., Shaub, F.J., McMillan, K.J., Ladd, J.W., and Worzel, J.L., 1979, Seismic reflection evidence for the widespread occurrence of possible gas hydrate horizons on continental slopes and rises: Am. Assoc. Petroleum Geologists Bull., v. 63, no. 12, p. 2204 $-2213$.

Shor, G.G., 1964, Structure of the Bering Sea and the Aleutian Ridge: Marine Geol., v. 1, p. 213 - 219.

Snowdon, L.R., and Powell, T.G., 1982, Immature oil and condensate modification of hydrocarbion generation mode for terrestrial organic matter: Am. Assoc. of Petroleum Geologists Bull, v. 66 no. 6, p. 775 - 788.

Steward, J.H., 1978, Basin-range structure in western North America (a Cenozoic tectonics and regional geophysics of the western Cordilleran: Geol. Soc. America Mem., v. 152, p. $1-31$.

Stoll, R.D., Ewing, J.I., and Bryan, G.H., 1971, Anomalous wave velocities in sediments containing gas hydrates: Jour. Geophys. Research, v. 76, p. 2090 - 2094.

Tissot, B.P., and Welte, D.H., 1978, Petroleum Formation and occurrence: Springer-Verlag, Heidelberg, 624 p.

Tucholke, B.E, Bryan, G.M., and Ewing, J.1., 1977, Gas hydrate horizons detected in seismic-profiler data from the western North Atlantic: Am. Assoc. Petroleum Geologists Bull., v. 61, p. 698.

Turner, F.R., McCarthy, C.M., Steffy, D.A., Lynch, M.B., Martin, G.C.: Sherwood, K.W., Flett, T.O., Adams, A.J., 1984, Geological and operational summary, Navarin Basin COST No. 1 well: OCS Report M.M.S. 84-0031, 241 p.

Vassoevich, N.B., Korchagina, Yu.L., Lopatin, N.V., and Chernyshev, V.V., 1969, Principal phase of oil formation: Int. Geol. Rev., no. 12, p. 1276 1296.

Verba, M.L., et al., 1971, Deep structure of northwestern part of the Bering Sea and the prospects of finding oil and gas (in Russian): Geofizicheskie Metody Razvedki v Arktike, v. 6, p. 70 - 74.

von Huene, R., 1979, Structure of the outer continental margin off Kodiak Island, Alaska, from multichannel seismic records, in J. Watkins and $\mathrm{L}$. Montadert, eds., Geological investigation of continental margins: Am. Assoc. Petroleum Geologists Mem. 29, p. 261 - 272.

von Huene, R., and Kulm, L.D., 1973, Tectonic summary of Leg 18, in Initial reports of the Deep Sea Drilling Project, Leg 18, L.D. Kuln and R. von Huene, eds., Washington, D.C., U.S. Govt. Printing Office, p. 961 - 976. 
von Huene, R., Miller, M., Fisher, M., and Smith, G., 1983, An eastern Aleutian Trench seismic record, in A.W. Bally, eds., Seismic expression of structural styles - A picture and work atlas: Am. Assoc. Petroleum Geoloists, Studies in Geology 15, v. 3.

von Huene, R., Moore, W., and Moore, C., 1979, Cross section, Alaska Peninsula - Kodiak Island - Aleutian Trench: Contribution of the plate margin group, U.S. Geodynamics Committee.

Waples, D., 1981, Organic geochemistry for exploration geologists: Burgess Publishing Co., 151 p.

Watanabe et al., 1977, Heat flow in back-arc basins of the western Pacific, in M. Talwani, and W.C. Pittman, eds., Island arcs, Deep Sea Trenches and Back-Arc Basins: Washington, Maurice Ewing Series 1, American Geophysical Union, p. $137-161$.

Whelan, T., III, Coleman, J.M., and Suhayda, J.N., 1975, The geochemistry of recent Mississippi River delta sediments: gas concentration and sediment stability: Houston, Texas. Proceedings of 7 th Offshore Technology Conference, p. 71 - 84.

Wilson, M.H., Russell, J.D., and Tait, J.M., 1974, A new interpretation of the structure of disordered $\alpha$-cristobalite: Contr. Miner. Petrol., v. 47, p. 1 6. 